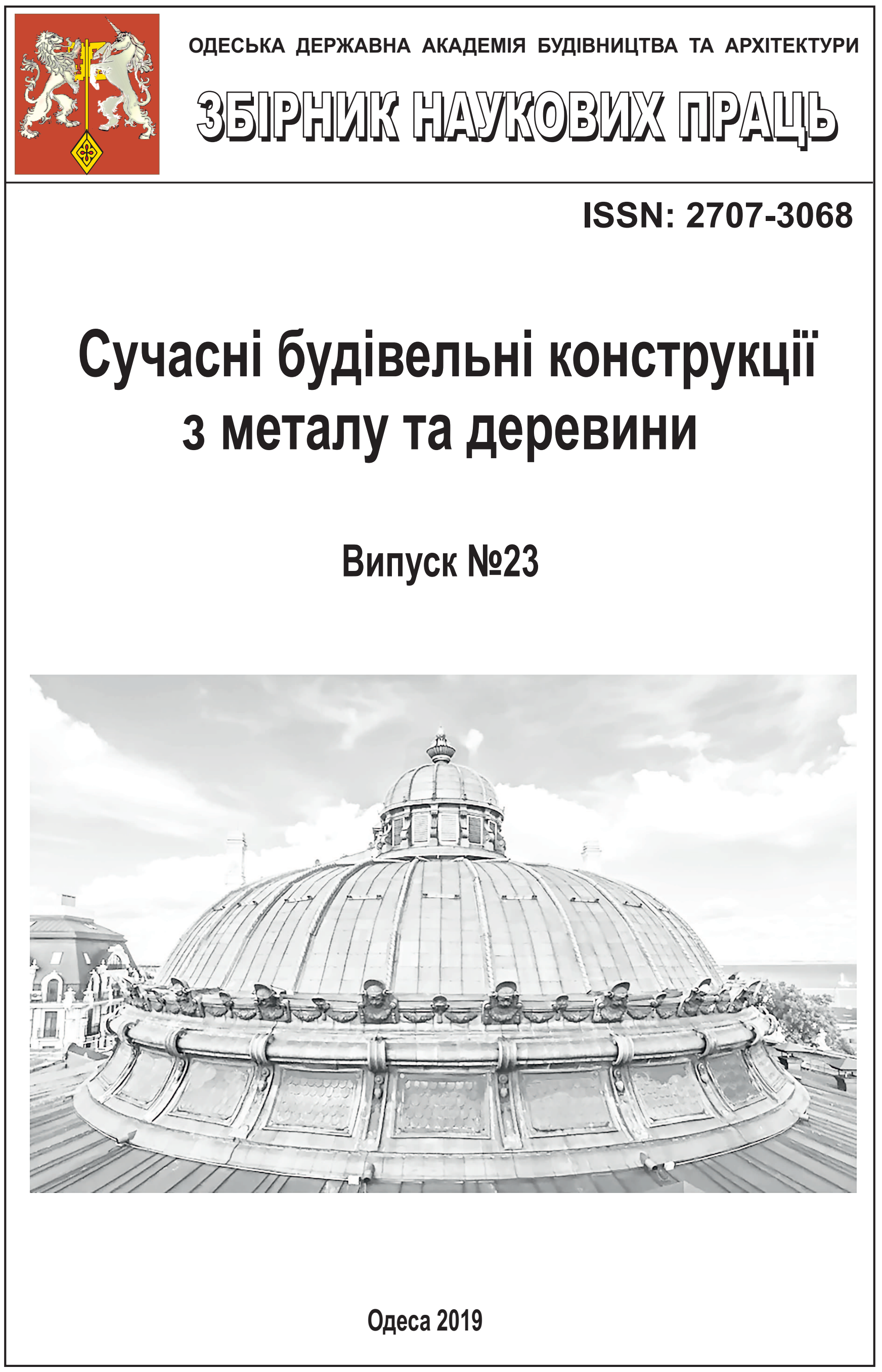


ISSN: 2707-3068

\section{МІНІСТЕРСТВО ОСВІТИ І НАУКИ УКРАЇНИ}

ОДЕСЬКА ДЕРЖАВНА АКАДЕМІЯ

БУДІВНИЦТВА ТА АРХІТЕКТУРИ

ЗБІРНИК НАУКОВИХ ПРАЦЬ

\section{СУЧАСНІ БУДІВЕЛЬНІ КОНСТРУКЦЇ̈ \\ 3 МЕТАЛУ ТА ДЕРЕВИНИ}

Випуск № 23

ОДЕСА 2019 


\section{СУЧАСНІ БУДІВЕЛЬНІ КОНСТРУКЦІї 3 МЕТАЛУ ТА ДЕРЕВИНИ}

\section{ISSN: 2707-3068}

Випуск № 23, 2019p.

Збірник наукових праць видається з 1992 р., періодичність - 1 раз на рік.

Засновник і видавець - Одеська державна академія будівництва та архітектури.

Свідоцтво про державну реєстрацію КВ 16172-4644Р від 02.12.2009

Збірник наукових праць входить до переліку наукових фахових видань України, у яких можуть публікуватися результати дисертаційних робіт. Наказ МОН України № 996 від 11.07.2017 року.

У збірнику представлені результати наукових і експериментально-теоретичних досліджень будівельних конструкцій з металу та деревини. Призначений для наукових працівників, спеціалістів проектних установ та виробничих підприємств будівельної галузі, аспірантів та магістрів навчальних закладів.

Головний редактор - Карпюк В.М. - д-р техн. наук, проф., ОДАБА;

Відповідальний редактор - Клименко Є.В. - д-р техн. наук, проф., ОДАБА;

Відповідальний секретар - Гілодо О.Ю. - к-т техн. наук, доц., ОДАБА.

\section{Редакційна колегія:}

Білик С.І. - д-р техн. наук, проф., Київський національний університет будівництва i архітектури;

Вировий В.М. - д-р техн. наук, проф., ОДАБА;

Гібаленко О.М. - д-р техн. наук, проф., ДВНЗ «Приазовський державний технічний університет»;

Голоднов О.І. - д-р техн. наук, проф., ТОВ «Укрінсталькон ім. В.М. Шимановського»;

Махінько А.В. - д-р техн. наук, с.н.с., Національний авіаційний університет;

Найчук А.Я. - д-р техн. наук, проф., УО «Брестский государственный технический университет»;

Пічугін С.Ф. - д-р техн. наук, проф., Полтавський національний технічний університет імені Юрія Кондратюка;

Суханов В.Г. - д-р техн. наук, проф., ОДАБА;

Яковенко І.А. - д-p техн. наук, проф., Національний університет біоресурсів i природокористування України.

Технічна редакція:

Арсірій А.М. - к-т техн. наук, доц., ОДАБА.

Бояджі А.О. - к-т техн. наук, ст. викл., ОДАБА.

Рекомендовано до видання Вченою радою ОДАБА

Протокол № XXX від ХXXXXX 2019 р.

Свідоцтво КВ 16172-4644Р від 02.12.2009

Наказ МОН України № 996 від 11.07.2017 p.

(c) Одеська державна академія будівництва та архітектури

(ОДАБА), 2019 
ISSN: 2707-3068

MINISTRY OF EDUCATION AND SCIENCE OF UKRAINE ODESSA STATE ACADEMY

OF CIVIL ENGINEERING AND ARCHITECTURE

COLLECTION OF SCIENTIFIC WORKS

MODERN STRUCTURES OF METAL AND WOOD

Issue № 23

ODESSA 2019 


\section{MODERN STRUCTURES OF METAL AND WOOD}

ISSN: 2707-3068

Issue № 23, 2019p.

Collection of scientific works has been published since 1992, frequency - 1 per year.

Founder and publisher - Odessa State Academy of Civil Engineering and Architecture (OSACEA).

Certificate of state registration KB № 16772-4644P, 02 December, 2009.

Collection of scientific works enters the list of scientific editions of Ukraine, in which thesis results can be published. Order of the Ministry of Education and Science of Ukraine № 996, 11 July, 2017.

Results of scientific and experimental-theoretical researches of building structures of metal and wood. It is assigned for scientific workers, specialists of design organizations and manufacturing enterprises of construction domain, postgraduates, masters of educational institutions.

Editor-in-chief - Karpiuk V.M. - D.Sc., Professor, OSACEA;

Executive editor - Klymenko Y.V. - .Sc., Professor, OSACEA;

Executive Secretary - Gilodo A.Y. - Ph.D., Associate Professor, OSACEA.

\section{Editorial Board:}

Bilyk S.I.- D.Sc., Professor, Kyiv National University of Construction and Architecture;

Vyrovoy V.N. - D.Sc., Professor, Odessa State Academy of Civil Engineering and Architecture;

Gibalenko O.M. - D.Sc., Professor, State Higher Education Institution "Pryazovskyi State Technical University";

Holodnov O.I. - D.Sc., Professor, LLC "V. Shimanovsky Ukrainian Institute of Steel Construction";

Makhinko A.V. - D.Sc., Professor, National Aviation University;

Naichuk A.Y. - D.Sc., Professor, Brest State Technical University;

Pichugin S.F. - D.Sc., Professor, National University «Yuri Kondratyuk Poltava Polytechnic»;

Sukhanov V.G. - D.Sc., Professor, Odessa State Academy of Civil Engineering and Architecture;

Yakovenko I.A. - D.Sc., Professor, National university of life and environmental sciences of Ukraine.

\section{Technical editorship:}

Arsirii A.M. - Ph.D., Associate Professor, OSACEA;

Boyadzhi A.O. - Ph.D., Senior lecturer, OSACEA.

Recommended for publication by the Academic Board of the OSACEA

Protocol № XXX, XXXXXXXXXXX.

Certificate KB № 16172-4644P, 02 December, 2009.

Order of Ministry of Education and Science of Ukraine № № 996, 11 July, 2017.

(C) Odessa State Academy

of Civil Engineering and Architecture

(OSACEA ), 2019 


\section{ДОСЛДЖЕННЯ ВПЛИВУ ЖОРСТКОСТІ ШПУНТУ НА НАПРУЖЕНО- ДЕФОРМОВАНИЙ СТАН ПРИЧАЛЬНИХ ТОНКИХ СТІНОК}

Безушко Д.І., к.Т.н., доцент, dibezushko@gmail.com ORCID 0000-0003-2215-1136

Одеський національний морский університет

Арсірій А.М., к.т.н., доцент,

ORCID 0000-0003-3262-1488

Одеська державна академія будівництва та архітектури

Коробенко О. В., магістр

Придністровський державний університет ім. Т.Г. Шевченко, Республіка Молдова

Анотація. Майже 45\% причалів в Україні, за конструктивною схемою відносяться до тонких стінок. Основним несучим елементом є лицьова та анкерна стінки, що виконуються із стального шпунту. У практиці проектування причальних тонких стінок, до теперішнього часу широко використовуються методи, що базуються на класичній теорії тиску. При цьому самі стінки розглядаються як вертикальні балки, що знаходяться під впливом активного і пасивного тиску грунту, що визначаються за формулами Кулона (методи Е. Якобі, БлюмаЛомейера та ін.). Однак, зусилля в елементах конструкцій виявляються завищеними, а конструктивні рішення - неекономічними. В роботі наведено аналіз впливу зміни жорсткості шпунту на роботу всієї конструкції. Розглядається шпунт Ларсен 5, що випускався різними виробниками і виходив в трьох модифікаціях Л 5, Л 5Д, Л 5-УМ. Використовується метод скінченних елементів, що реалізований в програмному комплексі PLAXIS. У розрахунковій схемі конструкції тонкої стінки представлені основні конструктивні елементи: лицьова $\mathrm{i}$ анкерна стінки, анкерні тяжі, грунти основи і засипки.

Встановлено, що зміна жорсткості шпунту найбільше впливає на деформації та величину згинального моменту. Так при збільшені жорсткості $3107 * 10^{3}$ до $160 * 10^{3}$ кНм/м момент в стінці і максимальне переміщення змінюються на $10 \%$.

Ключові слова: тонка стінка, больверк, морський порт, причал, метод скінчених елементів.

Вступ. Провідною галуззю матеріального виробництва є транспорт, без якого було б неможливе подолання територіального розриву між виробництвом і споживанням товарів $\mathrm{i}$ послуг. Саме завдяки розвитку морського транспорту океан вже не поділяє, а з'єднує країни і континенти. Одним 3 головних елементів складної системи «Порт» - $\epsilon$ причальна конструкція, яка й забезпечує транспортні процеси. Майже 45\% причалів в Україні, за конструктивною схемою, відносяться до тонких стінок.

Аналіз останніх досліджень та публікацій. У практиці проектування причальних тонких стінок до теперішнього часу широко використовуються методи, що базуються на класичній теорії тиску. При цьому самі стінки розглядаються як вертикальні балки, що знаходяться під впливом активного i пасивного тиску грунту, що визначаються за формулами Кулона (методи Е. Якобі, Блюма-Ломейера та ін.) [1, 2, 3]. Однак, одержувані при цьому зусилля в елементах конструкцій виявляються завищеними, а конструктивні рішення-неекономічними. Тому аналіз впливу зміни жорсткості стінки на напруженодеформований стан, 3 використанням сучасних методів розрахунку $[4,6,9]$ всієї системи $\epsilon$ актуальною задачею. 3 розвитком сучасних методів розрахунку (метод скінченних елементів) та систем, що забезпечують аналіз даних, можливо отримувати більш точні результати [4, 6, 9]. Для забезпечення надійності розрахунків ми будемо порівнювати отримані результати методу скінчених елементів з результатами натурного експерименту, виконаного Ренгач В.Н. [5]. 
Метою дослідження - $\epsilon$ визначення величини впливу змін характеристик жорсткості шпунту Л 5, Л 5Д, Л 5-УМ на напружено-деформований стан тонких стінок.

Для досягнення мети дослідження потрібно було вирішити наступні задачі:

1. Побудувати розрахункову схему причалу в PLAXIS;

2. Виконати розрахунки для трьох значень жорсткості шпунту;

3. Виконати порівняльний аналіз отриманих даних 3 результатами натурного експерименту, виконаного Ренгач В.Н. [5].

Матеріали та методика дослідження. При створенні розрахункової схеми необхідно вводити дані про споруду та грунтові умови, а недостатність вихідних даних або їх неповнота, можуть викликати невизначеність, яка може привести до помилок в розрахунках $[7,8]$. Якщо з геометричними розмірами все зрозуміло (рис.1), то 3 міцністю та деформаційними характеристиками можуть виникнути деякі труднощі. Ми умовно розділили питання 3 невизначеністю характеристик на два види: перший - зміна міцності і деформаційних характеристик металевих конструкцій, а другий - пов'язаний 3 характеристиками грунтів. В даній роботі наведено аналіз впливу жорсткості шпунту на роботу всієї конструкції.

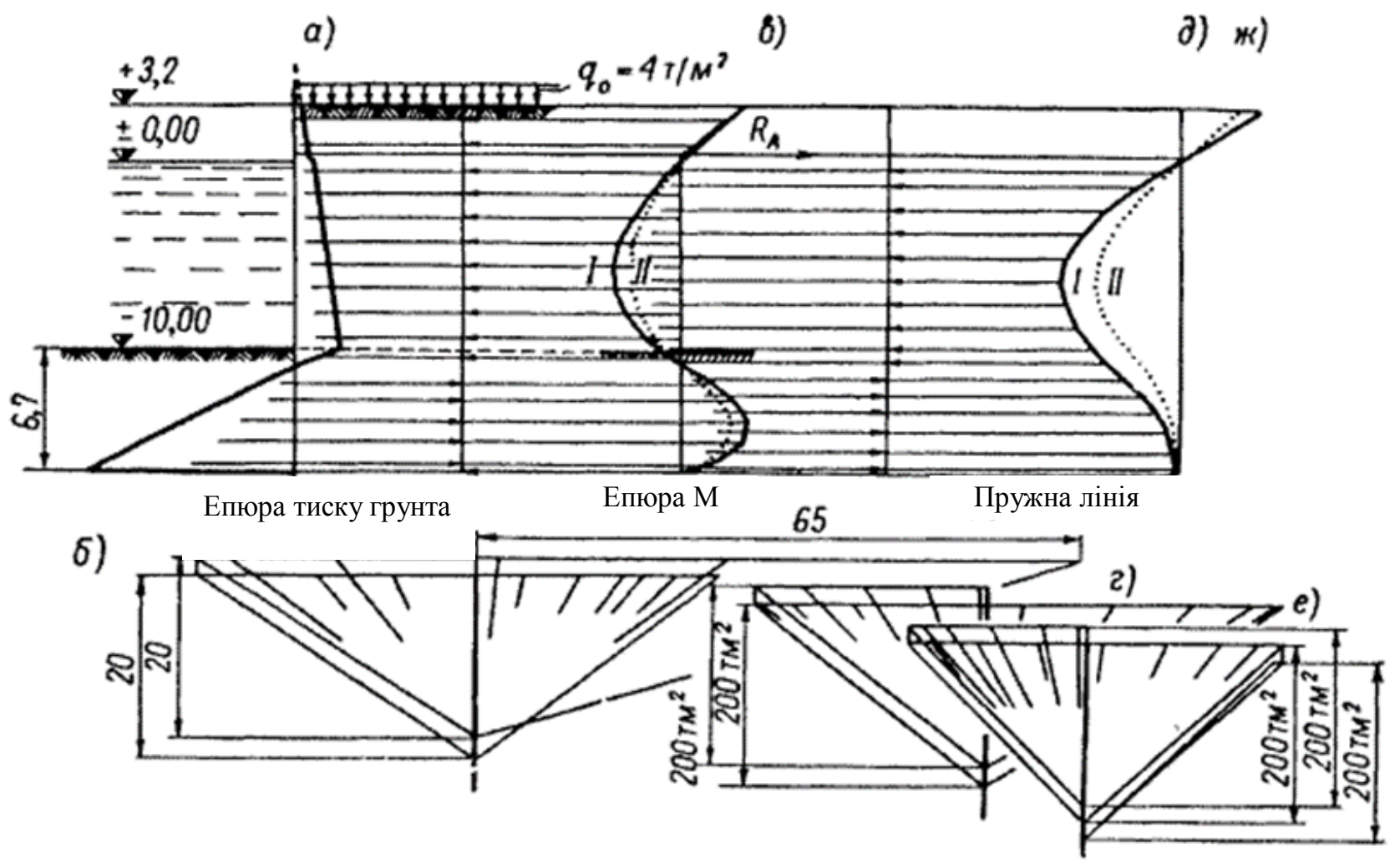

Рис.1. Розміри та графоаналітичний розрахунок за [5]

У розрахунковій схемі конструкції тонкої стінки повинні бути представлені основні конструктивні елементи: лицьова і анкерна стінки, анкерні тяжі, грунти основи і засипки. Розрахунок причальної стінки виконувався в програмному комплексі PLAXIS (Рис.2).

При завданні шпунтової стінки в плоскій деформації необхідно використовувати жорсткість стінки на стиск (AE) та жорсткість на згин (IE), тобто добуток модуля деформації на площу і момент інерції перерізу, відповідно. В роботі [5] представлені результати експериментальних досліджень по вивченню напружено-деформованого стану причалу типу «больверк» із сталевого шпунта «Ларсен 5» глибиною біля причалу 10м (Рис.1). 


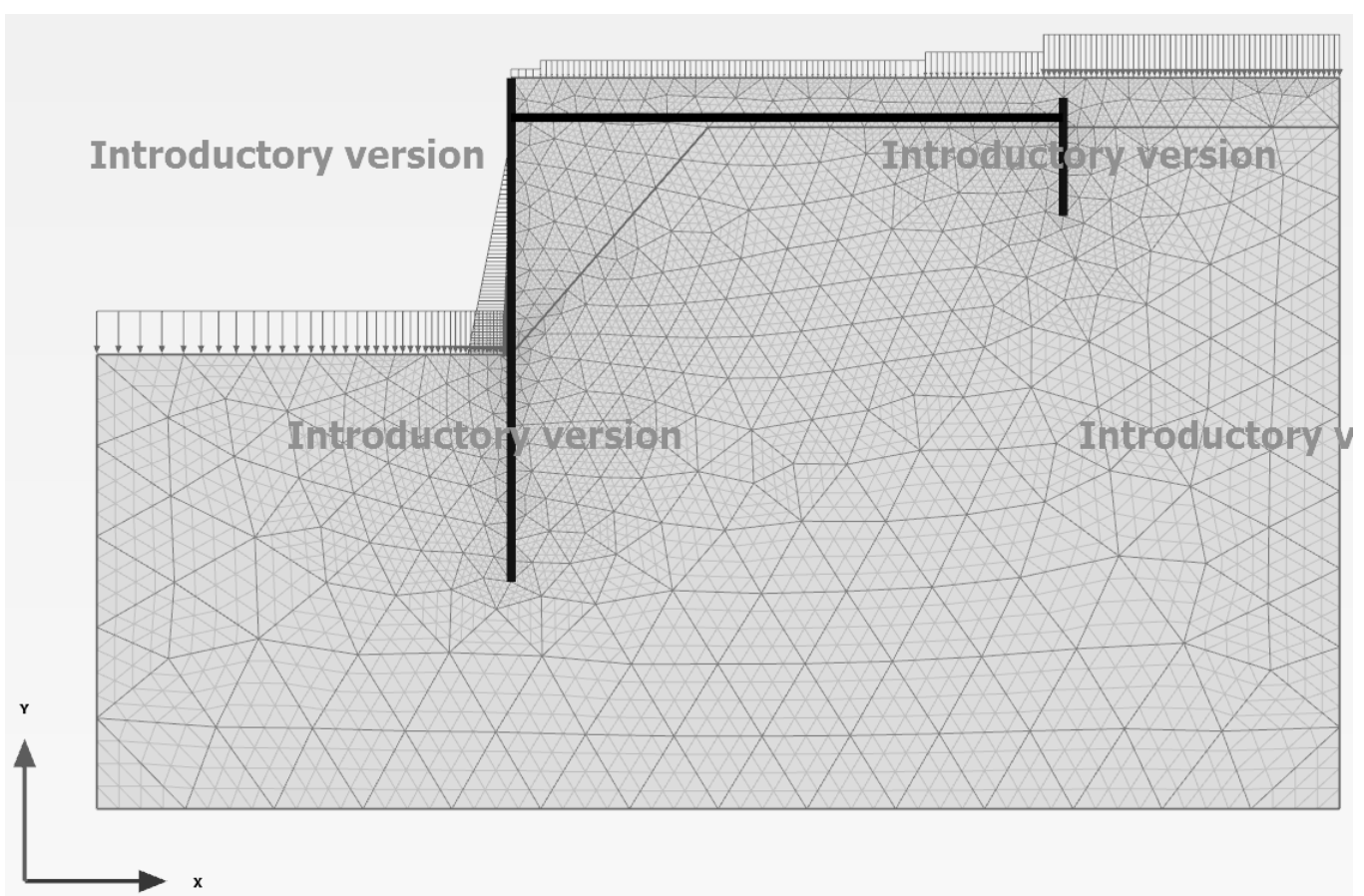

Рис.2. Розрахункова схема

У свою чергу шпунт «Ларсен 5» випускався різними виробниками і виходив в трьох модифікаціях Л 5, Л 5Д, Л 5-УМ. При невизначеності вихідних даних слід виконати аналіз впливу зміни жорсткості стінки на напружено-деформований стан всієї системи «больверк». Саме тому ми вирішили виконати аналіз впливу зміни жорсткості стінки на напруженодеформований стан всієї системи. Дані про характеристики шпунту наведені в табл. 1, a характеристики грунту - у табл. 2.

Таблиця 1 - Властивості матеріалу стінки (шпунту)

\begin{tabular}{|c|c|c|c|c|c|}
\hline \multirow{2}{*}{ Параметр } & \multirow{2}{*}{$\begin{array}{c}\text { Наймену- } \\
\text { вання }\end{array}$} & \multicolumn{3}{|c|}{ Значення параметрів } & \multirow{2}{*}{$\begin{array}{c}\text { Од. } \\
\text { виміру }\end{array}$} \\
\hline & & Л5 & Л5Д & Л5-УМ & \\
\hline Тип поведінки & $\begin{array}{c}\text { Material } \\
\text { type }\end{array}$ & Elastic & Elastic & Elastic & \\
\hline Нормальна жорсткість & $E A$ & $7.56 \cdot 10^{6}$ & $5.59 \cdot 10^{6}$ & $6.09 \cdot 10^{6}$ & $\kappa \mathrm{H} / \mathrm{M}$ \\
\hline Згинальна жорсткість & $E I$ & $107 \cdot 10^{3}$ & $146 \cdot 10^{3}$ & $160 \cdot 10^{3}$ & $\kappa \mathrm{HM}^{2} / \mathrm{M}$ \\
\hline Еквівалентна товщина & $d$ & 0.41 & 0.18 & 0.56 & $\mathrm{M}$ \\
\hline Вага & $w$ & 24 & 21 & 23 & $\kappa \mathrm{H} / \mathrm{M} / \mathrm{M}$ \\
\hline Коефіцієнт Пуассона & $v$ & 0,3 & 0,3 & 0,3 & - \\
\hline
\end{tabular}

Таблиця 2 - Властивості матеріалів основи

\begin{tabular}{|l|c|c|c|}
\hline \multicolumn{1}{|c|}{ Параметр } & $\begin{array}{c}\text { Наймену- } \\
\text { вання }\end{array}$ & Шар піску & $\begin{array}{c}\text { Од. } \\
\text { виміру }\end{array}$ \\
\hline Модель матеріалу & Model & Мор-Кулон & - \\
\hline Тип поведінки матеріалу & Type & Дренований & - \\
\hline Питома вага грунту & $\gamma_{\text {unsat }}$ & 20 & $\mathrm{\kappa H} / \mathrm{m}^{3}$ \\
\hline Питома вага насиченого грунту & $\gamma_{\text {sat }}$ & 21 & $\mathrm{\kappa H} / \mathrm{m}^{3}$ \\
\hline Модуль Юнга (константа) & $\mathrm{E}_{\text {ref }}$ & 28000 & $\mathrm{\kappa H} / \mathrm{m}^{2}$ \\
\hline Коефіцієнт Пуассона & $v$ & 0,3 & - \\
\hline Зчеплення (константа) & $\mathrm{c}_{\text {ref }}$ & 1,0 & $\mathrm{\kappa H} / \mathrm{m}^{2}$ \\
\hline Кут тертя & $\varphi$ & 28 & $\circ$ \\
\hline
\end{tabular}


Результати аналізу впливу жорсткості лицьової стінки на напружено-деформований стан конструкції представлені в табл. 3 та у вигляді гістограми на рис.3.

Таблиця 3 - Вплив жорсткості лицьової стінки на напружено-деформований стан конструкції

\begin{tabular}{|l|c|l|c|c|c|c|}
\hline \multicolumn{1}{|c|}{ Параметр } & Найм. & Од. вим. & Л5 & Л5Д & Л5УМ & По [5] \\
\hline Максимальний згинальний & $\mathrm{M}+$ & кНм/м & 246 & 242 & 240 & \\
\cline { 2 - 8 } момент в лицьовій стінці & $\mathrm{M}-$ & кНм/M & 447 & 474 & 482 & 460 \\
\hline Поздовжня сила & $\mathrm{N}$ & кН & 375 & 374 & 377 & \\
\hline Поперечна сила & $\mathrm{Q}$ & $\kappa \mathrm{H}$ & 178 & 180 & 180 & \\
\hline Максимальні переміщення & $\mathrm{U}_{\mathrm{x} \max }$ & $\mathrm{cм}$ & 11 & 10.4 & 10 & 10 \\
\hline Зусилля в тязі & $\mathrm{N}_{\text {тяга }}$ & кН & 340 & 340 & 340 & 365 \\
\hline $\begin{array}{l}\text { Згинальний момент в } \\
\text { анкерної стінці }\end{array}$ & $\mathrm{M}-$ & кНм/м & 173 & 175 & 176 & \\
\hline
\end{tabular}

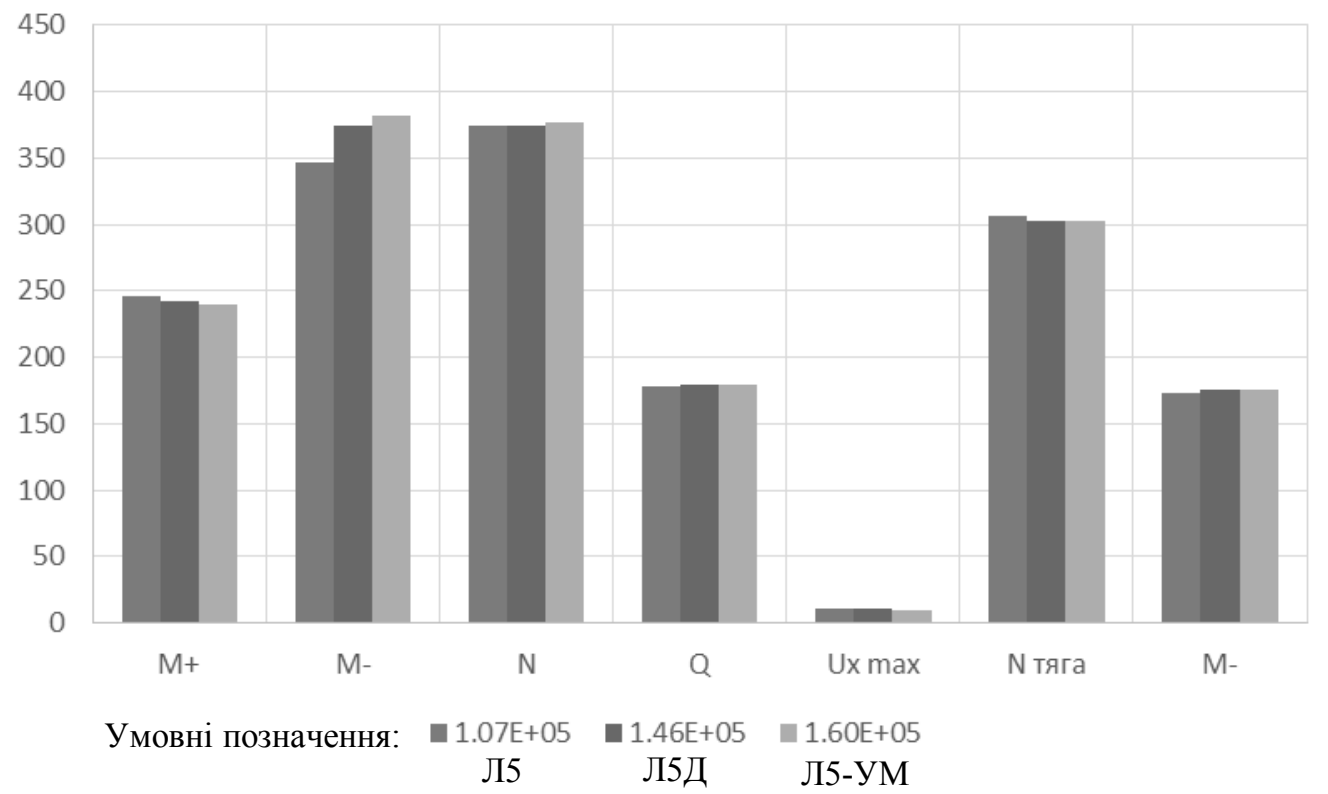

Рис.3. Вплив жорсткості лицьової стінки на напружено-деформований стан конструкції

Висновки. Відповідно до отриманих результатів, наведених у табл. 3 та на рис. 3, можна зробити наступні висновки:

1. Отримані зусилля збігаються з результатами натурного експерименту, проведеного Ренгач В.Н. [5].

2. Зміна жорсткості шпунта найбільше впливає на величину деформацій та згинального моменту. Так, зі збільшенням жорсткості з $107 * 10^{3}$ до $160 * 10^{3}$ кНм/м момент у лицьовій стінці та максимальне переміщення змінюються на 10\%.

\section{Література}

1. Ворожцов Е. В. Разностные методы решения задач механики сплошных сред: Учеб. пособие. - Издательство НГТУ - Новосибирск, 1998. - 86с.

2. ДБН В.2.1-10-2009 Основи та фундаменти споруд. М.: Мінрегіонбуд України,2009

3. Дуброва Г.А. Взаимодействие грунта и сооружений. - М.: Транспорт, 1963. -220 с.

4. Клованич, С. Ф., Безушко Д.И. Метод конечных элементов в нелинейных расчетах пространственных железобетонных конструкций. - Одесса: ОНМУ, 2009, 93с.

5. Ренгач В.Н. Шпунтовые стенки. Расчет и проектирование. Издательство литературы по строительству: Ленинград, 1970, 106с. 
6. Фадеев А.Б. Метод конечных элементов в геомеханике. - Недра. - Москва, 1987. $221 \mathrm{c}$.

7. Risk Management Standard. FERMA 2002 [Електронний ресурс]. - Режим доступу: https://docs.google.com/viewer?a=v\&pid=sites\&srcid=ZGVmYXVsdGRvbWFpbnxoYXphcmR2a WV3fGd4OjU1MmZiYTRIYTc5NmM5ZTQ.]

8. Werner S. D. Seismic risk management for seaports / Werner S. D., Rix G. J., DesRoches R. // 4th World Conference on Earthquake Engineering, Beijing, China. - 2008. - Режим доступу: http://www.iitk.ac.in/nicee/wcee/article/14_S30-003.PDF.

9. Zienkiewicz O. C. The finite element method. - Megrow-Hill Book Company (UK) Limited, 1986. - 787 p.

\section{References}

1. Vorozhtsov Ye. V. Raznostnyye metody resheniya zadach mekhaniki sploshnykh sred: Ucheb. posobiye. - Izdatel'stvo NGTU - Novosibirsk, 1998. - 86s.

2. DBN V.2.1-10-2009 Osnovi ta fundamenti sporud. M.: Mínregíonbud Ukraïni,2009

3. Dubrova G.A. Vzaimodeystviye grunta i sooruzheniy. - M.: Transport, 1963 - $220 \mathrm{~s}$.

4. Klovanich, S. F., Bezushko D.I. Metod konechnykh elementov v nelineynykh raschetakh prostranstvennykh zhelezobetonnykh konstruktsiy. - Odessa: ONMU, 2009, 93s.

5. Rengach V.N. Shpuntovyye stenki. Raschet i proyektirovaniye. Izdatel'stvo literatury po stroitel'stvu: Leningrad, 1970, 106s. $221 \mathrm{~s}$.

6. Fadeyev A.B. Metod konechnykh elementov v geomekhanike. - Nedra. - Moskva, 1987. -

7. Risk Management Standard. FERMA 2002 [Yelektronniy resurs]. - Rezhim dostupu: https://docs.google.com/viewer?a=v\&pid=sites\&srcid=ZGVmYXVsdGRvbWFpbnxoYXphcmR2a WV3fGd4OjU1MmZiYTRIYTc5NmM5ZTQ.]

8. Werner S. D. Seismic risk management for seaports / Werner S. D., Rix G. J., DesRoches R. // 4th World Conference on Earthquake Engineering, Beijing, China. - 2008. - Rezhim dostupu: http://www.iitk.ac.in/nicee/wcee/article/14_S30-003.PDF.

9. Zienkiewicz O. C. The finite element method. - Megrow-Hill Book Company (UK) Limited, 1986. -787 p.

\section{ИССЛЕДОВАНИЕ ВЛИЯНИЯ ЖЕСТКОСТИ ШПУНТ НА НАПРЯЖЕННО- ДЕФОРМИРОВАННОГО СОСТОЯНИЯ ПРИЧАЛЬНЫХ ТОНКИХ СТЕНОК}

Безушко Д.И., к.т.н., доцент,
dibezushko@gmail.com ORCID 0000-0003-2215-1136
Одесский национальный морской университет

Арсирий А.Н., к.т.Н., доцент,

ORCID 0000-0003-3262-1488

Одесская государственная академия строительства и архитектуры

Коробенко О. В., магистр

Аннотация. Почти 45\% причалов в Украине, по конструктивной схеме, относятся к тонким стенкам. Основным несущим элементом является лицевая и анкерная стенки, выполняемые из стального шпунта. В практике проектирования причальных тонких стенок, до настоящего времени широко используются методы, основанные на классической теории давления грунта. При этом сами стенки рассматриваются как вертикальные балки, находятся под влиянием активного и пассивного давления грунта, определяются по формулам Кулона (методы Э. Якоби, Блюма-Ломейера и др.). Однако получаемые при этом усилия в элементах конструкций оказываются завышенными, а конструктивные решения - неэкономичными. В 
работе приведен анализ влияния изменения жесткости шпунта на работу всей конструкции. Рассматривается шпунт Ларсен 5, который выпускался различными производителями и выходил в трех модификациях Л 5, Л 5Д, Л 5-УМ. Используется метод конечных элементов, реализованный в программном комплексе PLAXIS. B расчетной схеме конструкции тонкой стенки представлены основные конструктивные элементы: лицевая и анкерная стенки, анкерные тяги, грунт основания и засыпки.

Согласно полученным результатам, можно сделать вывод, что изменения жесткости шпунта всего влияет на величину изгибающего момента и на деформации. Так с увеличением жесткости с $107 * 10^{3}$ до $160 * 10^{3}$ кНм/м момент в лицевой стенке и максимальное перемещение изменяются на $10 \%$.

Ключевые слова: тонкая стенка, больверк, морской порт, причал, метод конечных элементов.

\title{
RESEARCH OF INFLUENCE OF GROOVING PLANE RIGIDITY ON STRENGTH- DEFORMED CONDITION OF BERTHS THIN WALLS
}

\author{
Bezushko D.I., Ph.D., Assistant Professor \\ dibezushko@gmail.com ORCID 0000-0003-2215-1136 \\ Odessa National Maritime University \\ Arsirii A.M., Ph.D., Assistant Professor, \\ ORCID: 0000-0003-3262-1488 \\ Odessa State Academy of Civil Engineering and Architecture \\ Korobenko O.V., master's degree \\ Bendery Polytechnic Branch of the TSU named after T.G. Shevchenko, Moldova
}

\begin{abstract}
Almost $45 \%$ of berths in Ukraine, according to the construction scheme refer to thin walls. The main bearing element is the front and anchor walls, made of steel grooving plane. In the practice of designing berths thin walls, thus far, methods based on classical pressure theory are widely used. The walls themselves are considered as vertical beams, which are under the influence of active and passive soil pressure, determined by the Coulomb formulas (E. Jacobi, BloomLomeyer methods, etc.). However, efforts in structural elements prove to be overstated and constructive decisions are uneconomical. In the work the analysis of influence of grooving plane hardness change on the work of the whole structure is presented. We consider the Larsen 5 grooving plane, manufactured by different manufacturers and came out in three modifications L 5, L 5D, L 5-UM. The finite element method implemented in PLAXIS is used. In the calculation scheme of the thin-wall construction, the main structural elements are represented: front and anchor walls, anchor strands, foundation soil and backfill. When creating a calculation scheme, it is necessary to enter data on the structure and soil conditions, and the lack of initial data or their incompleteness may cause uncertainty, which can lead to errors in the calculations.

The purpose of the study is to determine the magnitude of the influence of changes in the hardness characteristics of the grooving plane L 5, L 5D, L 5-UM on the stress-strain state of thin walls.

To achieve the goal of the study the following tasks were solved:

1. Build a berth calculation scheme in PLAXIS;

2. Perform calculations for three levels of grooving plane rigidness;

3. Perform a comparative analysis of the data obtained with the results of a field experiment, which was performed by Rengach V. N. [5]

According to the results obtained, it can be concluded that changes in the rigidness of grooving plane have the greatest effect on the deformation and magnitude of bending moment. So with increased rigidity from $107 * 10^{3}$ to $160 * 10^{3} \mathrm{kNm} / \mathrm{m}$ moment in the wall and maximum displacement are changed by $10 \%$.
\end{abstract}

Keywords: thin wall, revetment, seaport, berth, finite elements method. 


\title{
ОБЕСПЕЧЕНИЕ ДОЛГОВРЕМЕННОГО ХРАНЕНИЯ МЕТАЛЛОКОНСТРУКЦИЙ ПРИ ИСПОЛЬЗОВАНИИ ВТОРИЧНОЙ ПРОТИВОКОРРОЗИОННОЙ ЗАЩИТЫ
}

\author{
Гибаленко А.Н., Д.т.н., профессор \\ grin196102@gmail.com, ORCID:0000-0003-2979-5225 \\ Трофимчук T.C., ассистент \\ ГВУЗ «Приазовский государственный технический университет» \\ taras.trofimchook@gmail.com, ORCID:0000-0002-1051-4561
}

\begin{abstract}
Аннотация. Исследования направлены на повышение качества мер вторичной защиты при подготовке производстве листовых металлоконструкций. Решается задача сохранения качества с гарантированными показателями долговечности при учете уровня коррозионной опасности в условиях приморского климата. Использованы принципы процессного подхода для реализации задач управления сроком службы в коррозионных средах. Обеспечивается принцип надежности по уровню коррозионной опасности, который описывается последовательными этапами оценки живучести листовых металлоконструкций на основе стратегии DMAIC (define, measure, analyze, improve, control): определения, измерения, анализа, совершенствования и контроля мер первичной и вторичной защиты от коррозии..
\end{abstract}

Ключевые слова: металлические листовые конструкции; живучесть; процессный подход; обеспечение надежности.

Введение. Совершенствование нормативно-технических требований в области безопасности металлоконструкций при производстве, изготовлении, эксплуатации [1, 2] связано с обоснованным учетом уровня коррозионной опасности, который определяется критическими интервалами коэффициента готовности противокоррозионной защиты металлоконструкций при воздействии факторов коррозионных сред [3]. Особенностями комбината АЗОВСТАЛЬ (Azovstal Iron \& Steel Works) является производство и поставка стального листа со значительным периодом нахождения конструкций в условиях воздействия коррозионных сред приморской и морской среды. Такая среда относится к категориям C4...С5 с очень высокой коррозионной агрессивностью [4]. Это требует решения задачи обеспечения коррозионной защищенности с учетом уровня коррозионной опасности и требований первичной и вторичной защиты от коррозии [5].

Оценка качества и надежности металлоконструкций и временных покрытий является важным аспектом продления ресурса объектов основных фондов, формирования рационального инновационного развития производства новых материалов и использования ресурсосберегающих технологий. Прогнозируемый уровень коррозионной опасности позволяет сформировать требования к обеспечению мероприятий первичной и вторичной защиты от коррозии соответствующие условиям нормальной эксплуатации [6, 7]. Вместе с этим, неопределенность критериев оценки состояния поверхности металлопроката и коррозионного разрушения создает трудности для оперативного принятия решений с целью обеспечения технологической безопасности объектов [8].

Цель. Исследования направлены на обеспечение качества и надежности мер первичной и вторичной защиты листовых металлоконструкций по признакам коррозионной опасности.

Соблюдение условий надежности и конструктивной безопасности достигается за счет решения задачи обеспечения технологической безопасности на основе методологии всеобщего управления качеством [9].

Значительный уровень износа и предельные сроки нахождения в неблагоприятных условиях являются угрозами снижения качества продукции, что влечет повышение требований к улучшению эксплуатационных свойств конструкций, которые теряют качество [10].

Определение проектных показателей долговечности конструкций основано на разработанной методике учета коэффициентов надежности и готовности временной противокорро- 
зионной защиты, установленных по результатам экспериментальных исследований свойств первичной и вторичной защиты при определительных (ускоренных или стендовых) испытаниях согласно классификационным признакам коррозионных сред [11].

В настоящее время оценка коррозионного состояния металлических конструкций выполняется в соответствии с требованиями отечественных норм [12].

Влияние коррозионных повреждений на долговечность в нормах предлагается учитывать путем изменения геометрических характеристик сечения на основе данных о величине равномерной коррозии и коэффициента слитности сечения, что делает невозможным учет особенностей неравномерного (местного) разрушения конструктивных элементов. Показатель глубины проникновения коррозии определяется без учета доверительного интервала статистической погрешности измерений. В то же время нормами [13] допускаются меры первичной защиты (увеличение толщины проката) с учетом уровня коррозионной опасности.

Материалы и методика исследования. Целью работы является обоснование состава и структуры параметров коррозионной стойкости конструкций для управления технологической безопасностью путем снижения рисков, что уменьшает вероятность коррозионного разрушения и ограничивает возможный ущерб при коррозионных разрушениях конструкций и сооружений.

Влияние внешних факторов (агрессивная среда) и внутренних параметров (конструктивная форма) на показатели надежности строительных листового металлопроката рассматривается для зон расположения групп однородных конструктивных элементов (партии поставок) с учетом вида и интенсивности коррозионных воздействий. В соответствии с представленным подходом (табл. 1), основным показателем агрессивных сред является характеристическое значение годовых коррозионных потерь $\mathrm{An}$, г $/ \mathrm{m}^{2} *$ год, условно приведенное к незащищенной поверхности стали класса С 235 [6].

Коррозионное разрушение стальных конструкций определяется внешними воздействиями режима эксплуатации и зависит в первую очередь от степени агрессивности среды. Учет электрохимической кинетики коррозионного разрушения в изменении прочности производится на основе физических моделей, характеризующих изменения геометрических параметров и свойств материала во времени при агрессивных воздействиях сред [14]. С позиций аппарата строительной механики, допустимое снижение несущей способности элементов для заданной системы противокоррозионной защиты конструкций (СПЗК) можно учитывать в расчетах по предельным состояниям с помощью фиктивных внешних нагрузок [3, 4]. Цель работы заключается в обосновании условий мониторинга и диагностики признаков коррозионной опасности при техническом обслуживании строительных металлоконструкций по фактическому состоянию.

Таблища 1 - Классификация коррозионных сред

\begin{tabular}{|c|c|c|c|c|}
\hline $\begin{array}{lr}\text { Степень } & \text { агрес- } \\
\text { сивности } & \text { по } \\
\text { ДСТУ Б } & \text { В.2.6- } \\
193: 2013 & \end{array}$ & \begin{tabular}{l}
\multicolumn{2}{|c}{ Коррозион- } \\
ная стойкость \\
стали \\
мм/*год
\end{tabular} & $\begin{array}{l}\text { Коррозион- } \\
\text { ные потерь } \\
\text { стали С 235, } \\
\mathrm{A}_{\mathrm{n}}, \text { г/м } \mathrm{M}^{2} \text { год }\end{array}$ & \begin{tabular}{|l|}
\multicolumn{2}{|c|}{ Степень } \\
агрессив- \\
ности по \\
СНиП \\
2.03.11-85 \\
\end{tabular} & $\begin{array}{l}\text { Обозначение катего- } \\
\text { рии коррозии по } \\
\text { ISO 12944-2 } \\
\mathrm{A}_{\mathrm{n}}, \text { г/м²* год }\end{array}$ \\
\hline $\begin{array}{l}\text { A4 высоко- } \\
\text { агрессивная }\end{array}$ & $\begin{array}{l}0,08 \ldots 0,20 \\
0,008 \ldots 0,02\end{array}$ & $650 \ldots 1500$ & \multirow[t]{2}{*}{$\begin{array}{l}\text { В3 средне- } \\
\text { агрессивная }\end{array}$} & $\begin{array}{l}\text { С5-1 очень высокая } \\
\text { (промышленная) } \\
650 \ldots 1500 \\
\text { С5-М очень высокая } \\
\text { (морская) } \\
650 \ldots 1500\end{array}$ \\
\hline $\begin{array}{l}\text { А5 } \\
\text { очень высоко- } \\
\text { агрессивная }\end{array}$ & $\begin{array}{l}0,20 \ldots 0,50 \\
0,02 \ldots 0,05\end{array}$ & $1500 \ldots 3900$ & & - \\
\hline
\end{tabular}


Допустимые отклонения эксплуатационных характеристик конструктивных элементов в зависимости от категории ответственности систем защиты от коррозии учитываются коэффициентами надежности противокоррозионной защиты $\left(\gamma_{z k}, \gamma_{z n}\right)$. Требования к показателям долговечности вторичной защиты устанавливают с учетом заданного срока подготовки $T_{n \gamma}$ металлических конструкций, индекса надежности $\beta$, степени агрессивности воздействий среды.

Комплексным показателем ремонтопригодности - коэффициентом готовности $\left(K_{g}\right)$, характеризуются параметры конструктивных и технологических мер первичной и вторичной защиты:

$$
K_{g}=\frac{T_{k \gamma}+T_{z \gamma}}{T_{k \gamma}},
$$

где $T_{k \gamma}$ срок службы (год) стальных конструкций по показателю коррозионной стойкости (первичная защита);

$T_{z \gamma}$ - расчетный срок службы (год) временной защиты с доверительной вероятностью $\gamma=0,95$ по результатам ускоренных испытаний.

Расчет на коррозионную стойкость, долговечность и ремонтопригодность конструкций выполняется с учетом параметров коррозионной стойкости (табл.2) по предельным состояниям. Обеспечения надежности и конструктивной безопасности на стадии подготовки производства включает обоснование расчетных ситуаций исходя из условий условиям живучести систем защиты от коррозии. Задание срока службы конструкций по характеристикам первичной защиты (коррозионная стойкость конструкции) производится с учетом резерва несущей прочностных свойств и степени агрессивности воздействий на основе расчетов. Задание срока службы осуществляется на основе анализа показателей качества систем защиты.

Результаты исследований. В соответствии с изложенным подходом сформулированы требования к определению фактических значений коррозионной агрессивности воздействий по данным контроля контрольного норматива $K_{p}$ эксплуатации объектов определяющего эффективность мер программы обеспечения надежности на основании мониторинга показателей качества СПЗК при техническом обслуживании по фактическому состоянию.

Таблица 2 - Условия соответствия мер защиты проектным требованиям качества.

\begin{tabular}{|c|c|c|c|c|c|c|}
\hline \multicolumn{4}{|c|}{ Шкала стойкости металлов и покрытий } & \multirow[b]{3}{*}{ 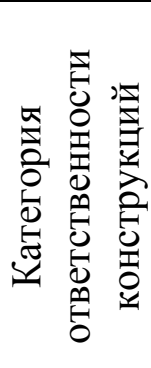 } & \multirow{2}{*}{\multicolumn{2}{|c|}{$\begin{array}{c}\text { Коэффициенты } \\
\text { надежности защиты }\end{array}$}} \\
\hline & & & & & & \\
\hline $\begin{array}{c}\text { Группа } \\
\text { стойкости по } \\
\text { ГОСТ 13819- } \\
68\end{array}$ & $\begin{array}{c}\text { Оценка } \\
\text { стойкости, } \\
\text { балл }\end{array}$ & $\begin{array}{c}\text { Глубина } \\
\text { поражений, } \\
\text { мм/год }\end{array}$ & $\begin{array}{c}\text { первичной и } \\
\text { вторичной } \\
\text { защиты по } \\
\text { СНиП } \\
\text { (ДСТУ) }\end{array}$ & & 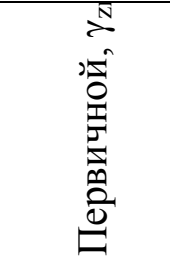 & 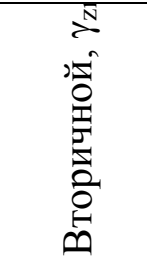 \\
\hline $\begin{array}{l}\text { Нестойкие } \\
\text { (IV) }\end{array}$ & $\begin{array}{l}8 \\
7 \\
\end{array}$ & $\begin{array}{c}1-5 \\
0,5-1 \\
\end{array}$ & I & $\mathrm{C} 4$ & $\begin{array}{l}\text { От } 0,80 \\
\text { до } 0,85\end{array}$ & $\begin{array}{l}\text { От } 0,85 \\
\text { до } 0,90\end{array}$ \\
\hline $\begin{array}{l}\text { Понижен- } \\
\text { ностойкие } \\
\text { (III) }\end{array}$ & $\begin{array}{l}6 \\
5\end{array}$ & $\begin{array}{c}0,1-0,5 \\
0,05-0,1\end{array}$ & II & $\mathrm{C} 3$ & $\begin{array}{l}\gg 0,85 \\
\gg 0,90\end{array}$ & $\begin{array}{l}\gg 0,90 \\
\gg 0,95\end{array}$ \\
\hline $\begin{array}{c}\text { Удовлетворит } \\
\text { ельно стойкие } \\
\text { (II) }\end{array}$ & $\begin{array}{l}4 \\
3\end{array}$ & $\begin{array}{r}0,01-0,05 \\
0,005-0,01\end{array}$ & III & $\mathrm{C} 2$ & $\begin{array}{l}\gg 0,90 \\
\gg 0,95\end{array}$ & $\begin{array}{l}\gg 0,95 \\
\gg 0,99\end{array}$ \\
\hline $\begin{array}{l}\text { Стойкие } \\
\text { (I) }\end{array}$ & $\begin{array}{l}2 \\
1\end{array}$ & $\begin{array}{l}0,001-0,005 \\
\text { Менее } 0,001\end{array}$ & IV & $\mathrm{C} 1$ & $\begin{array}{l}\gg 0,95 \\
\gg 0,99\end{array}$ & $\begin{array}{l}\gg 0,99 \\
\gg 1,00\end{array}$ \\
\hline
\end{tabular}


Репрезентативные значения показателей контрольного норматива $K_{p}$ используются для расчетной оценки коэффициентов надежности по коррозионной стойкости материала $\left(\gamma_{m k}\right)$ и характеристических значений годовых коррозионных потерь $\left(A_{n}, \Gamma^{2}{ }^{2}\right.$ год) - основного показателя агрессивности среды. Расчетно-экспериментальная оценка показателей долговечности защитных покрытий выполнена на основе моделирования физико-химических воздействий в процессе ускоренных испытаний образцов с защитными покрытиями, предназначенными для долговременной защиты от коррозии. Практическая реализация методического подхода осуществлена в период мониторинга выпуска продукции комбината АЗОВСТАЛЬ (Azovstal Iron \& Steel Works) при производстве, хранении и транспортировки листовых металлоконструкций по признакам коррозионной опасности (Рис. 1).

Разработанная стратегия временной противокоррозионной защиты листовых металлоконструкций в условиях производственного предприятия при воздействии факторов среды морского климата. Мероприятия включают включает процессный подход к управлению ресурсами путем построения системы учета и функционального контроля, анализа рисков и регулирования технологической безопасности производственных фондов предприятий с учетом уровня коррозионной опасности. Реализация подхода к управлению технологической безопасностью на объектном уровне направлена на совершенствование СПЗК, продление ресурса с учетом показателей живучести и обоснование мер ПОН.

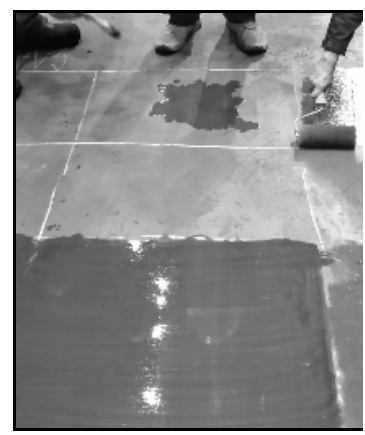

1

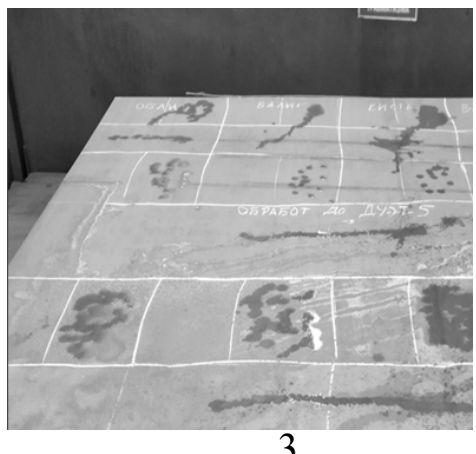

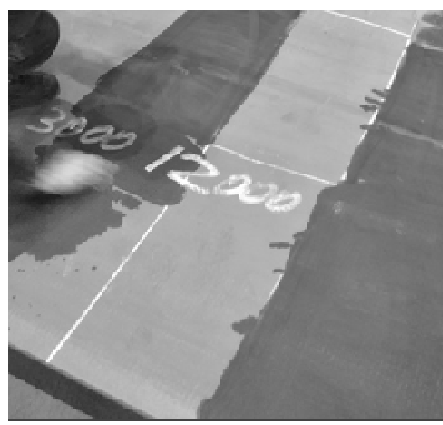

2

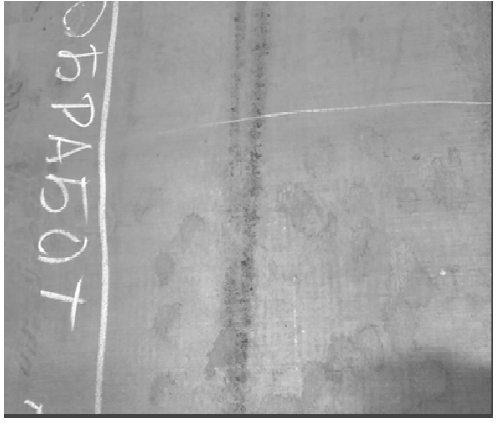

4

1 - участки нанесения; 2 - условия нанесения; 3 - места контроля. 4 - внешний вид контрольных участков (экспозиция 2 суток)

Рис. 1. Изучение коррозионной защищенности при натурных исследованиях.

Выводы. Назначение мер защиты от коррозии по критерию коррозионной опасности позволяет обеспечивать требования надежности и соответствия нормативным требования качества листовых металлоконструкций [15] на основе и решать задачи по управлению технологической безопасностью в течение установленного срока:

- выявлять отклонения от требований действующих нормативных документов по защите от коррозии;

- оценивать соответствие показателей качества, конструктивной приспособленности и технологической рациональности решений противокоррозионной защиты заданному уровню коррозионной опасности; 
- определять требования к выбору материалов и систем защитных покрытий металлоконструкций согласно классификационным признакам нормативных требований;

- разрабатывать предложения по использованию решений противокоррозионной защиты на основании экспертизы новых материалов и технологий по условиям оценки соответствия требованиям надежности и эффективности.

\section{Литература}

1. Проблеми ресурсу і безпеки експлуатації конструкцій, споруд та машин / Цільова комплексна програма НАН України. Зб. наук. ст. за результатами, отриманими в $2007-2009$ pp. Наук. керівник - академік Б.С. Патон. - К.: IЕЗ ім. С. О. Патона НАН України, - 2009. 709 c.

2. Шимановський О.В. Концептуальні основи системи технічного регулювання надійності й безпечності будівельних конструкцій / Шимановський О.В., Корольов В.П. // Промислове будівництво та інженерні споруди, №1, -2008, с. 4-9.

3. Гибаленко, А. Н. Мониторинг остаточного ресурса металлоконструкций в коррозионных средах / А. Н. Гибаленко // Зб. наук. пр. Серія: галузеве машинобудування, буд-во. Полтава: ПолтНТУ, 2015. - Вип. 3 (45). - С. 110- 116.

4. ISO 9223:2012 Corrosion of metals and alloys - Corrosivity of atmospheres - Classification, determination and estimation Number of pages: 15.

5. Королёв В.П., Филатов Ю.В., Селютин Ю.В. Развитие корпоративной системы менеджмента: технологическая безопасность производственных объектов / Королёв В.П., Филатов Ю.В., Селютин Ю.В. Зб. наук. праць Укрінсталькон ім. В.М. Шимановського // Під заг. ред. засл. діяча науки і тех-ки України, д.т.н., проф. О.В. Шимановського. Вип.14. - К.: Видво «Сталь», -2014, с. $136-149$.

6. Sumi Y, Strength and Deformability of Corroded Steel Plates Estimated by Replicated Specimens (Journal of Ship Production, 24(3), 2008), pp. 161-167.

7. Estimation of steel structure corrosion risk level / V. P. Korolov, Y. Vysotsky, O. M. Gibalenko, P. V. Korolov // Eurocorr-2010. The European Corrosion Congress (13.09-17.09.2010) / From the Earth`s Depths to Space Heights. - Moscow, 2010. - Book of Abstracts. -534 p.

8. Korolov V. Design criteria of reliability and safety in the design of corrosion protection of structural steel / V. Korolov, Y. Vysotskyy, Y. Filatov / EUROCORR-2014. The European Corrosion Congress «Improving materials durability: from cultural heritage to industrial applications». Pisa, Book of Abstracts. - 2014. - 88 p.

9. ДСТУ Б В.2.6-193:2013 Захист металевих конструкцій від корозії. Вимоги до проектування. - Мінрегіон України. - 74 с.

10. ДБН В.2.6-198:2014 Сталеві конструкції. Норми проектування / Мінрегіон України. Київ, 2014. - 199 с.

11. American Rust Standard Guide. New York: American Institute for Steel Classification. American rust standard guide. New York: American Institute for Steel Classification, c. 1968 (OCoLC)746104088, Media Type: Book. Publisher: American Institute for Steel Classification. Publish Date: 31/12/2002. Code ID: 24016. Pages: 12

\section{References}

[1] Problemi resursu i` bezpeki ekspluataczi yi konstrukczi j, sporud ta mashin / Czi`lova kompleksna programa NAN Ukrayini. Zb. nauk. st. za rezul tatami, otrimanimi v $2007-2009$ rr. Nauk. keri`vnik - akademi'k B.Ye. Paton. - K.: IEZ i’m. Ye. O. Patona NAN Ukrayini, 2009.

[2] Shimanovs `kij O.V. Konczeptual`ni` osnovi sistemi tekhni`chnogo regulyuvannya nadi jnosti` j bezpechnosti` budi`vel’nikh konstrukczi’j / Shimanovs `kij O.V., Korol’ov V.P. // Promislove budi`vnicztvo ta i’nzhenerni` sporudi, \#1, -2008. 
[3] Gibalenko, A. N. Monitoring ostatochnogo resursa metallokonstrukczij v korro-zionny`kh sredakh / A. N. Gibalenko // Zb. nauk. pr. Seri ya: galuzeve mashinobuduvannya, bud-vo. Poltava: PoltNTU, 2015.

[4] ISO 9223:2012 Corrosion of metals and alloys - Corrosivity of atmospheres - Classi-fication, determination and estimation, 2012.

[5] Korolyov V.P., Filatov Yu.V., Selyutin Yu.V. Razvitie korporativnoj sistemy menedzhmenta: tekhnologicheskaya bezopasnost' proizvodstvenny'kh ob`ektov / Korolyov V.P., Filatov Yu.V., Selyutin Yu.V. Zb. nauk. pracz` Ukri`nstal`kon i’m. V.M. Shimanovs`kogo // Pi`d zag. red. zasl. di yacha nauki i’ tekh-ki Ukrayini, d.t.n., prof. O.V. Shimanovs'kogo. Vip.14. - K.: Vid-vo «Stal`», -2014.

[6] Sumi Y, Strength and Deformability of Corroded Steel Plates Estimated by Replicated Specimens (Journal of Ship Production, 24(3), 2008.

[7] Estimation of steel structure corrosion risk level / V. P. Korolov, Y. Vysotsky, O. M. Gibalenko, P. V. Korolov // Eurocorr-2010. The European Corrosion Congress (13.09-17.09.2010) / From the Earth`s Depths to Space Heights. - Moscow, 2010.

[8] Korolov V. Design criteria of reliability and safety in the design of corrosion protection of structural steel / V. Korolov, Y. Vysotskyy, Y. Filatov / EUROCORR-2014. The European Corrosion Congress «Improving materials durability: from cultural heritage to industrial applications». - Pisa, Book of Abstracts. - 2014.

[9] DSTU B V.2.6-193:2013 Zakhist metalevikh konstrukczi`j vi`d korozi yi. Vimogi do proektuvannya. - Mi’nregi`on Ukrayini, 2013.

[10] DBN V.2.6-198:2014 Stalevi` konstrukczi`yi. Normi proektuvannya / Mi`nregi’on Ukrayini. Kiyiv, 2014.

[11] American Rust Standard Guide. New York: American Institute for Steel Classification. American rust standard guide. New York: American Institute for Steel Classification, c. 1968 (OCoLC)746104088, Media Type: Book. Publisher: American Institute for Steel Classification. Publish Date: 31/12/2002. Code ID: 24016. Pages: 12

\section{ЗАБЕЗПЕЧЕННЯ ДОВГОТРИВАЛОГО ЗБЕРІГАННЯ МЕТАЛОКОНСТРУКЦЙ ПІД ЧАС ВИКОРИСТАННЯ ВТОРИННОГО ПРОТИКОРОЗІЙНОГО ЗАХИСТУ}

Гібаленко О.М., д.т.н., професор, grin196102@gmail.com, ORCID:0000-0003-2979-5225

Трофимчук T.C. , асистент ДВНЗ «Приазовський державний технічний університет», taras.trofimchook@gmail.com, ORCID:0000-0002-1051-4561

Анотація. Дослідження спрямовані на підвищення якості заходів вторинного захисту при підготовці виробництва листових металоконструкцій. Вирішується завдання збереження якості з гарантованими показниками довговічності при врахуванні рівня корозійної небезпеки в умовах приморського клімату. Використано принципи процесного підходу для реалізації завдань управління терміном служби в корозійних середовищах. Забезпечується принцип надійності за рівнем корозійної небезпеки, який описується послідовними етапами оцінки живучості листових металоконструкцій на основі стратегії DMAIC (define, measure, analyze, improve, control): визначення, вимірювання, аналізу, вдосконалення та контролю заходів первинної та вторинного захисту від корозії. Розроблено заходи захисту від корозії за критерієм корозійної небезпеки, що забезпечує дотримання вимог надійності будівельних металоконструкцій на основі розрахункових показників. Вирішення завдань управління технологічної підготовленістю протягом встановленого терміну, що передує зведенню будівельного об'єкта. Розроблено процедуру обслуговування листового металопрокату по фактичному стану, 
яка заснована на процесному підході до управління ресурсами шляхом побудови системи обліку і функціонального контролю, аналізу ризиків та регулювання технологічної безпеки. Реалізація цих принципів на об'єктному рівні спрямована на вдосконалення засобів і методів протикорозійного захисту, продовження ресурсу з урахуванням показників живучості та обгрунтування заходів програми забезпечення надійності (ПЗН). На основі розробленого принципу узагальнені результати натурних і лабораторних досліджень. Ці дослідження спрямовані на обгрунтування первинного та вторинного захисту листових металоконструкцій при заданому рівні корозійної небезпеки, запропоновані організаційні заходи ПЗН. Заходи включають оцінку інтегральних характеристик конструктивної пристосованості, технологічної раціональності і ризик-аналіз ознак корозійної небезпеки об'єктів.

Ключові слова: металеві листові конструкції; живучість; процесний підхід; забезпечення надійності.

\title{
ENSURING LONG-TERM STORAGE OF METAL STRUCTURES WHEN USING SECONDARY ANTI-CORROSION PROTECTION
}

\author{
Gibalenko O. M., doctor of technical sciences, professor, \\ grin196102@gmail.com, ORCID:0000-0003-2979-5225 \\ Trofymchuk T. S., assistant \\ State Higher Education Institution "Pryazovskyi State Technical University" \\ taras.trofimchook@gmail.com, ORCID:0000-0002-1051-4561
}

Annotation. Research is aimed at improving the quality of secondary protection measures in preparation for the production of sheet metal structures. The problem of maintaining quality with guaranteed indicators of durability is taken into account, taking into account the level of corrosion hazard in a coastal climate. The principles of the process approach are used to implement the tasks of managing the service life in corrosive environments. The principle of reliability according to the level of corrosion hazard is provided, which is described by the successive stages of assessing the survivability of sheet metal structures based on the DMAIC strategy (define, measure, analyze, improve, control): determination, measurement, analysis, improvement and control of primary and secondary corrosion protection measures. Corrosion protection measures have been developed according to the criterion of corrosion hazard, which ensures compliance with the reliability requirements of building metal structures based on calculated indicators. The tasks of managing technological readiness for a specified period preceding the construction of a building object have been solved. A procedure has been developed for servicing sheet metal according to the actual state, which is based on a process approach to resource management by building a system of accounting and functional control, risk analysis and technological safety regulation. The implementation of these principles at the object level is aimed at improving the means and methods of anticorrosive protection, extending the resource taking into account survivability indicators and substantiating measures of the reliability assurance program (PON). Based on the developed principle, the results of field and laboratory studies are generalized. These studies are aimed at substantiating the primary and secondary protection of sheet metal structures at a given level of corrosion hazard, organizational measures of PON are proposed. Activities include the assessment of the integral characteristics of constructive fitness, technological rationality and risk analysis of signs of corrosion hazard of objects.

Key words: sheet metal structures; survivability; process approach; ensuring reliability. 


\section{УСИЛЕННЫЕ ДЕРЕВЯННЫЕ ДВУТАВРЫ В МАЛОЭТАЖНОМ СТРОИТЕЛЬСТВЕ}

Гилодо А.Ю., к.т.Н., доцент, gil@soborka.net ORCID 0000-0001-5387-5538

Арсирий А.Н., к.т.н., доцент, ORCID 0000-0003-3262-1488

Одесская государственная академия строительства и архитектурь

Китаев А.А., директор

Гуренко В.И., гл. инженер $О О О$ «ЭКОДВУТАВР»

Аннотация. Каркасное деревянное домостроение с использованием деревянных двутавровых балок из деревянного клееного бруса и плиты OSB (oriental strand board) - новая технология, которая сегодня очень быстро развивается. Высокая механическая прочность и устойчивость к внешним воздействиям (в том числе влаги) позволяет использовать OSB в любой сфере хозяйственной деятельности. Традиционно при использовании подобных балок в перекрытиях используют упрощённую балочную клетку, что связано с ограниченной несущей способностью и шагом балок в пределах 400-500 мм. Для возможности использования балок в составе нормальной балочной клетки с повышенной несущей способностью исследовано напряженно - деформированное состояние металлодеревянных балок с клеевым соединением поясов и стенки и усиленных двухсторонними стальными листовыми накладками на саморезах в местах максимальных усилий и примыкания к другим балкам. Представлено конструктивное решение составной балки и результаты численных исследований ее работы под нагрузкой.

Ключевые слова: составная деревянная балка, пояса из древесины, плита OSB, метод конечных элементов, расчетная модель.

Введение. Клееные деревянные строительные конструкции (КДК) - это комплекс деревянных элементов, соединённых клеевым составом. Они совмещают несущие и теплозащитные функции, что особенно важно при их использовании в конструкциях стен и перекрытий. Проблема огнестойкости на самом деле для таких конструкций не более значительна, чем для стальных или железобетонных, а угроза гниения ликвидируется правильно подобранной химической пропиткой.

Каркасное строительство домов и коттеджей из клееной древесины - новая технология, которая сегодня очень быстро развивается. Широкое распространение она получила в Скандинавских странах, Канаде, Германии. Популярность каркасных домов растет благодаря многим положительным аспектам:

- высокая скорость возведения зданий;

- возможность строительства в любое время года;

- высокие эксплуатационные качества домов;

- возможность осуществления различных архитектурных идей;

- меньшая стоимость, примерно на 30 \%, по сравнению с кирпичными домами.

Применяемые в инновационных технологиях строительства материалы экологически безопасны, не деформируются, не изменяют своих свойств, имеют очень долгий срок эксплуатации.

Основа каркаса - деревянная двутавровая балка. Формула «цельный брус + OSB + цельный брус» позволяет избежать недостатков, присущих древесине, а благодаря двутавровому сечению достигаются высокие прочностные характеристики. Конечно, система двутавровых деревянных балок не может в полном объеме заменить бетон и сталь. Тем не 
менее, ряд конструктивных характеристик позволяет отнести деревянные двутавровые балки к эффективным и современным строительным конструкциям.

Достоинствами деревянной двутавровой балки являются:

- универсальность применения - каркасное строительство, мансарды, перекрытия, стропильные системы;

- небольшая масса балок позволяет вести работу без привлечения подъемной техники, балка перекрытия длиной 6,5 метра весит не более 40 кг;

- высокая скорость и простота монтажа балок при помощи обычного плотницкого инструмента;

- широкий сортамент конструкций;

- низкая теплопроводность;

- небольшой вес конструкций.

Наиболее наглядно преимущества деревянной балки выглядят в составе комплексной конструкции, например стены. Термическое сопротивление стены по деревянным стойкам из двутавров с утеплителем из минваты толщиной 150 мм и ограждающими панелями из листов OSB составляет 4,83 м² С/Вт, при весе $1 \mathrm{~m}^{2}-29$ кг, а оштукатуренной стены из пустотного

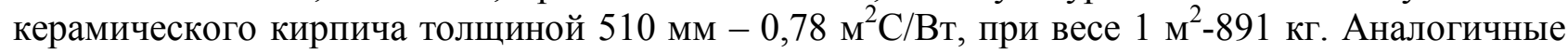
результаты даёт сравнительный анализ перекрытия. По деревянным балкам с подшивкой и настилом из OSB и утеплителем толщиной 100 мм термическое сопротивление составляет $6,9 \mathrm{~m}^{2} \mathrm{C} / \mathrm{B}$, при весе $1 \mathrm{~m}^{2}-60$ кг, а перекрытие по железобетонным многопустотным панелям пролётом $6 \mathrm{~m}-0,39 \mathrm{~m}^{2} \mathrm{C} /$ Вт при весе $1 \mathrm{~m}^{2}-440$ кг.

Одной из первых деревянная двутавровая балка в Украине была выпущена компанией «ЭКО ДВУТАВР» ещё в 2001 г. Её качество соответствует всем международным и украинским стандартам. Продукция производится согласно [1] из высококачественного столярного леса (сосны, влажностью 8\%, с применением технологии сращивания древесины), плиты OSB-3, толщиной 10 мм KRONOPOL, клея D3, метизов, антисептиков и антипиренов. Расчетная эксплуатационная равномерно распределенная нагрузка на перекрытие не превышает 3 кН/м². Технологический процесс изготовления балок состоит из следующих этапов:

- переработка древесины сосны (обрезка коры, нарезка на бруски, шипование, склейка бруса, сушка бруса);

- порезка OSB плит на станке;

- обработка антисептиком и антипиреном;

- склеивание в прессе брусков с OSB полосами;

- сушка готовых двутавров в сушильной камере.

Цель и задания. Одним из путей снижения трудовых и материальных затрат является широкое применение в малоэтажном строительстве составных деревянных индустриальных конструкций - двутавровых балок. Соединение деревянных поясов со стенкой из OSB выполняется в двух вариантах: на клею и металлическими нагелями - анодированными саморезами. Традиционно при использовании подобных балок в перекрытиях используют упрощённую балочную клетку, что связано с ограниченной несущей способностью и шагом балок в пределах 400-500 мм. Для возможности использования балок в составе нормальной балочной клетки с повышенной несущей способностью, предлагается исследовать напряженно-деформированное состояние металлодеревянных балок с клеевым соединением поясов и стенки и усиленных двухсторонними стальными листовыми пластинами на саморезах, образующих коробчатое сечение в местах максимальных усилий и примыкания к другим балкам. Такие балки, как конструкционный элемент, применяемый для строительства домов по каркасной технологии, могут найти применение при устройстве перекрытий, стропильных систем крыш и мансард.

Анализ существующих публикаций и исследований. Исследованием проблем оптимального проектирования деревянных двутавров занимались: Турков А.В., Коробко В.И., Стоянов В.В., Синцов В.П., Серов Е.Н., Лабудин В.П., Фурсов В.В., Горынин Г.Л., 
Вдовин В.М. та др. В работе [2] исследовано напряженно-деформированное состояние трехслойных двутавров, выполнены расчеты прогибов балки при помощи различных теорий. В [3] рассмотрены вопросы оптимизации усиления деревянных конструкций послойным армированием стеклотканью, изложены рекомендации по толщине и жесткости слоев. В [4] рассмотрены вопросы современного состояния балочных конструкций из клееных деревянных элементов, методы их расчета, приведены решения по выполнению жестких узлов балочных элементов.

Описание расчетной модели. Для анализа напряженно-деформированного состояния двутавровой балки в программном комплексе «ЛИРА-САПР» была разработана пространственная компьютерная модель балки из деревянных брусьев - поясов и стенки из полосы OSB, соединенных на клею. В середине балки и опорных зонах - местах максимальных изгибающих моментов и поперечных сил, а также на участках стыковки с балками настила предусмотрены листовые двухсторонние стальные накладки, прикрепленные к поясам саморезами. Жесткостные характеристики объемным конечным элементам задавались с учетом анизотропных свойств древесины и OSB в соответствии с требованиям [5] и [6].
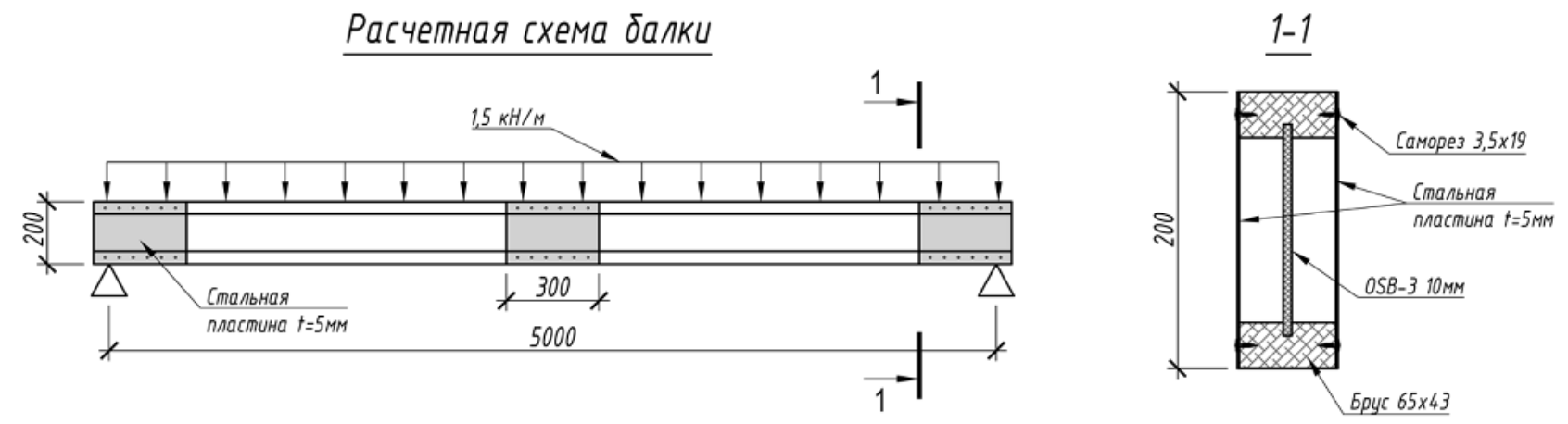

Рис. 1. Расчетная схема двутавровой балки

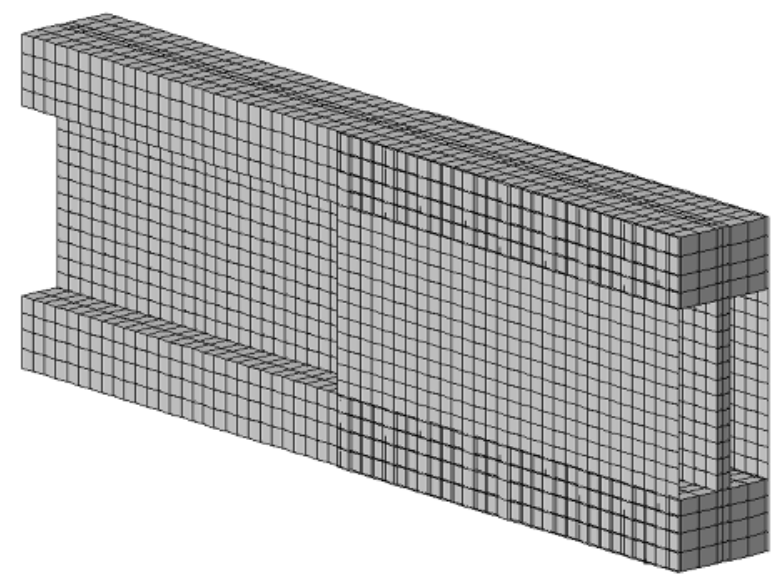

Рис. 2. Фрагмент расчетной модели (опорный участок балки)

Пояса и стенки балки смоделированы универсальными пространственными восьмиузловыми изопараметрическими конечными элементами (КЭ №36), металлические пластины - универсальными четырехугольными пластинчатыми конечными элементами оболочки (КЭ №44), саморезы - стержневыми элементами.

Геометрические характеристики балки: пояса сечением $65 \times 43$ мм выполнены из древесины 1 сорта, стенка выполнена из плиты OSB-3 толщиной 10 мм. Пролет балки 5 м, общая высота двутаврового сечения - 200 мм. Толщина стальных пластин - 2 мм, диаметр саморезов - 3,5 мм. Расчетная схема балки - балка на двух опорах, загруженная равномернораспределенной нагрузкой 1,5 кН/м.п. 


\section{Результаты исследований.}

Напряженно - деформированное состояние балки анализировалось по полям перемещений и напряжений, а также по деформациям конструкции. На 1 этапе производился расчет двутавровой балки без усиления стальными пластинами. На 2 этапе с пластинами в опорной зоне, на 3 этапе - с пластинами в опорной зоне и посередине пролета. Результаты расчетов в виде мозаики напряжений представлены на рис. 3, 4.

При усилении двутавровой балки стальными пластинами снижается прогиб балки на $12 \%$, при этом нормальные напряжения в поясах балки снижаются на 15\%. Результаты расчетов сведены в таблицу №1.

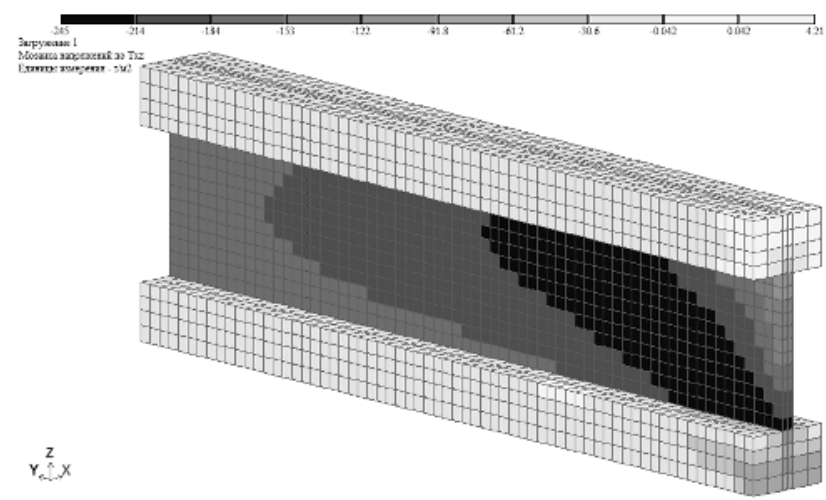

Рис. 3. Касательные напряжения в опорном участке балки без усиления

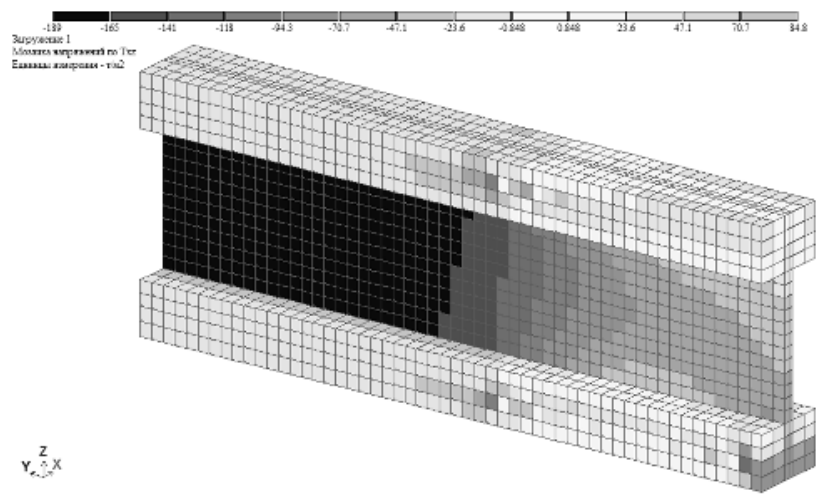

Рис. 4. Касательные напряжения в опорном участке балки, усиленном стальной пластиной

Таблица 1 - Результаты расчетов

\begin{tabular}{|c|c|c|c|}
\hline Расчетная модель балки & $\begin{array}{c}\text { Максимальный } \\
\text { прогиб, мм }\end{array}$ & $\begin{array}{c}\text { Нормальные } \\
\text { напряжения } \\
\text { в поясах, т/м }\end{array}$ & $\begin{array}{c}\text { Касательные } \\
\text { напряжения } \\
\text { в стенке, т/м }\end{array}$ \\
\hline Без усиления & 36 & 1250 & 245 \\
\hline $\begin{array}{c}\text { Балка усиленная } \\
\text { стальными пластинами } \\
\text { в опорной зоне }\end{array}$ & 34 & 1200 & 225 \\
\hline $\begin{array}{c}\text { Балка усиленная } \\
\text { стальными пластинами } \\
\text { в опорной зоне и в } \\
\text { середине пролета }\end{array}$ & 32 & 1050 & 210 \\
\hline
\end{tabular}

\section{Выводы}

1. Анализ распределения напряжений в элементах балки по длине и по сечению составной двутавровой деревянной балки показал эффективность конструктивного решения клееных деревянных двутавровых балок, усиленных стальными пластинами, для малоэтажного строительства.

2. Усиление балок стальными пластинами приводит к снижению нормальных и касательных напряжений на $15 \%$.

3. Усиление балок стальными пластинами в пролёте, с образованием коробчатого сечения, позволит реализовать балочную клетку нормального типа с соединением балок в одном уровень.

4. Усиление балок стальными пластинами с образованием коробчатых сечений, на участках с максимальными усилиями, повышает их жесткость и пространственную устойчивость балочной клетки. 


\title{
Литература
}

1. ТУ УВ 2.7_22794685_001.2005. Двутавровые деревянные балки. Технические условия [Текст]. - Одесса : ООО «ПОЛ и К», 2005. - 35 с.

2. Горынин Г.Л. Исследование напряженно-деформируемого состояния трехслойного двутавра в пространственной постановке [Текст] / Горынин Г.Л., Горынина О.Г. // Вестник СибАДИ. - ОМСК, 2012, - вып. 5 (27) - С. 49-53.

3. Стоянов, В. В. Экспериментальные исследования двутавровых деревянных балок [Текст] / В. В. Стоянов // Современные строительные конструкции из металла и древесины : Сб. научных трудов / Одес. гос. акад. стр_ва и архитектуры. - Одесса : ОГАСА, 2005. - Ч. 1. - C. 208-213.

4. Серов Е.Н. Клееные деревянные конструкции : состояние и проблемы развития / Е.Н. Серов, Б.В. Лабудин // Лесной журнал. - 2013. - № 2. - С. $72-78$

5. ДБН В.2.6-161:2017 Дерев`яні конструкції. Основні положення / Мінрегіон України. - Київ, 2017. - 111 с.

6. ДСТУ EN 300:2008. Плиты древесностружечные с ориентированной стружкой (OSB). Термины и определения понятий, классификация и технические требования (EN 300:2006, IDT) / Держспоживстандарт України. - Київ, 2011. - 11 с.

\section{References}

1. TU UV 2.7_22794685_001.2005. Dvutavrovyye derevyannyye balki. Tekhnicheskiye usloviya [Tekst]. - Odessa : OOO «POL i K», 2005. - 35 s.

2. Gorynin G.L. Issledovaniye napryazhenno-deformiruyemogo sostoyaniya trekhsloynogo dvutavra v prostranstvennoy postanovke [Tekst] / Gorynin G.L., Gorynina O.G. // Vestnik SibADI. - OMSK, 2012, - vyp. 5 (27) - C. 49-53.

3. Stoyanov, V. V. Eksperimental'nyye issledovaniya dvutavrovykh derevyannykh balok [Tekst] / V. V. Stoyanov // Sovremennyye stroitel'nyye konstruktsii iz metalla i drevesiny : Sb. nauchnykh trudov / Odes. gos. akad. str_va i arkhitektury. - Odessa : OGASA, 2005. - CH. 1. - C. 208-213.

4. Serov Ye.N. Kleyenyye derevyannyye konstruktsii : sostoyaniye i problemy razvitiya / Ye.N. Serov, B.V. Labudin // Lesnoy zhurnal. - 2013. - № 2. - S. $72-78$

5. DBN V.2.6-161:2017 Derev`yaní konstruktsîi. Osnovní polozhennya / Mínregíon Ukraïni. - Kï̈v, 2017. - $111 \mathrm{~s}$.

6. DSTU EN 300:2008. Plity drevesnostruzhechnyye s oriyentirovannoy struzhkoy (OSB). Terminy i opredeleniya ponyatiy, klassifikatsiya i tekhnicheskiye trebovaniya (EN 300:2006, IDT) / Derzhspozhivstandart Ukraïni. - Kï̈v, 2011. - $11 \mathrm{~s}$.

\section{ПІДСИЛЕНІ ДЕРЕВ'ЯНІ ДВОТАВРИ В МАЛОПОВЕРХОВОМУ БУДІВНИЦТВІ}

\author{
Гілодо О.Ю., к.т.н., доцент, \\ gil@soborka.net ORCID 0000-0001-5387-5538 \\ Aрсірій А.М., к.т.н., доцент, \\ ORCID 0000-0003-3262-1488 \\ Одеська державна академія будівництва та архітектури \\ Кітасв А.А., директор \\ Гуренко В.І., гол. інженер \\ ТОВ «ЕКОДВУТАВР»
}

Анотація. Каркасне дерев'яне житлове будівництво 3 використанням дерев'яних двотаврових балок з дерев'яного клеєного бруса і плити OSB (oriental strand board) - нова технологія, яка сьогодні дуже швидко розвивається. Висока механічна міцність і стійкість до 
зовнішніх впливів (в тому числі вологи) дозволяє використовувати OSB в будь-якій сфері господарської діяльності. Традиційно при використанні подібних балок в перекриттях використовують спрощену балочну клітку, що пов'язано з обмеженою несучою здатністю і кроком балок в межах 400-500 мм. Для можливості використання балок в складі нормальної балочної клітки пропонується посилення балок двосторонніми сталевими листовими накладками на саморізах в місцях максимальних зусиль і примикання до інших балок. Для аналізу напружено-деформованого стану двотаврової балки в програмному комплексі «ЛІРА-САПР» була розроблена просторова комп'ютерна модель. Напружено - деформований стан балки аналізувалося по полях переміщень і напружень, а також за деформаціями конструкції. На 1 етапі проводився розрахунок двотаврової балки без посилення сталевими пластинами. На 2 етапі з пластинами в опорній зоні, на 3 етапі - 3 пластинами в опорній зоні i посередині прольоту. Аналіз розподілу напружень в елементах балки по довжині і по перетину складовою двотаврової дерев'яної балки показав ефективність конструктивного рішення клеєних дерев'яних двотаврових балок, посилених сталевими пластинами, для малоповерхового будівництва. Посилення балок сталевими пластинами в прольоті, 3 утворенням коробчастого перетину, дозволить реалізувати балочну клітку нормального типу 3 з'єднанням балок в одному рівні. Посилення балок сталевими пластинами з утворенням коробчастих перерізів, на ділянках з максимальними зусиллями, підвищує їх жорсткість і просторову стійкість балочної клітки.

Ключові слова: складена дерев'яна балка, пояси 3 деревини, плита OSB, метод скінченних елементів, розрахункова модель.

\title{
STRENGTHENED WOODEN DOUBLE-T IN A LOW-HEIGHT BUILDING
}

\author{
Gilodo A.Y., Ph.D., Assistant Professor, \\ Arsirii A.M., Ph.D., Assistant Professor, \\ Odessa State Academy of Civil Engineering and Architecture \\ Kitayev A.A., director \\ Gurenko V.I., ch. engineer \\ $L L C$ "ECODVUTAVR"
}

\begin{abstract}
Prefabricated wooden housing with the use of wooden double-T beams made of wooden glued laminated lumber and OSB board (oriental strand board) - a new technology that is developing very fast today. High mechanical strength and resistance to external influences (including moisture) allows using OSB in any area of activities. Traditionally, when using such beams in the overlappings, a simplified beam framing is used, which is associated with limited bearing capacity and the pitch of beams within $400-500 \mathrm{~mm}$. For the possibility of using beams as part of a normal beam framing, it is proposed to reinforce the beams with double-sided steel sheet linings on the screws in places of maximum effort and to adhere to other beams. To analyze the stress-strain state of the double-T beam in the software complex "LIRA-SAPR" a spatial computer model was developed. The stress-strain state of the beam was analyzed by displacement and stress fields, as well as by deformations of the structure. At the 1st stage, the double-T beam was calculated without steel plates reinforcing. At the 2 nd stage with plates in the index zone, at the 3rd stage - with plates in the index zone and in the middle of the span. Analysis of pressure distribution in beam elements along the length and intersection of a component of a double-T beam has shown the effectiveness of a structural solution of glued wooden double-T beams reinforced with steel plates for low-height construction. The reinforcement of beams with steel plates in the span, with the formation of a box section, will allow realizing the beam framing of the normal type with the connection of beams in one level. Strengthening of beams with steel plates with the formation of box sections, in areas of maximum effort, increases their rigidity and spatial stability of the beam framing.
\end{abstract}

Keywords: stacked wooden beam, timber belts, OSB board, finite element method. 


\title{
ВИРІВНЮВАННЯ СТИСЛИХ СТАЛЕВИХ ДВОТАВРОВИХ ЕЛЕМЕНТІВ ПІСЛЯ РОЗВАНТАЖЕННЯ РІЗНИМИ СПОСОБАМИ
}

\author{
Голоднов О.І., д.т.н., проф., \\ ТОВ «Укрінсталькон ім. В.М. Шимановського», м. Київ, Україна, \\ golodnow@ukr.net; ORCID: 0000-0002-9722-9164 \\ Іванов Б.В., інженер \\ ТОВ «МегаСП», м. Київ, Украӥна \\ ivanov@megabp.com; ORCID: 0000-0002-9203-2987
}

Анотація. Викладена методика досліджень несучої здатності сталевих двотаврових елементів після первинного навантаження, розвантаження, подальшого вирівнювання i вторинного навантаження. Після випробувань на первинний стиск експериментальні зразки були вирівняні під пресом або шляхом наплавлення холостих валиків по опуклих кромках.

Наведено результати експериментального визначення несучої здатності зразків після розвантаження і вирівнювання. Результати випробувань показали, що несуча здатність для більшості зразків після вирівнювання виявилася не нижчою, ніж несуча здатність зразків, що була отримана при початкових випробуваннях.

Наведено результати практичного застосування результатів проведених досліджень при визначенні технічного стану сталевих колон.

Ключові слова: стислі сталеві елементи, розвантаження, вирівнювання, несуча здатність.

Введення. Постановка проблеми. В процесі навантаження i подальшого розвантаження, особливо після переходу матеріалу в пластичний стан, в конструкціях виникає залишковий напружений стан (ЗНС), який супроводжується залишковим вигином. Очевидно, що подальша надійна експлуатація конструкцій при навантаженні можлива після виключення залишкового вигину шляхом вирівнювання.

Способів вирівнювання, включаючи підсилення шляхом нарощування перерізу, існує багато, проте не всі способи можна застосувати до реальних конструкцій. Зокрема, не завжди вдається збільшити переріз внаслідок обмеженості або наявності устаткування поряд 3 конструкцією. До того ж, приварювання елементів підсилення сприяє зміні ЗНС, що може істотно відбитися на несучій здатності конструкцій. Цю обставину важливо враховувати при проектуванні підсилення конструкцій $[1,2]$.

Методику та програму експериментальних досліджень розроблено для отримання даних про характер розподілу залишкових напружень $(3 \mathrm{H})$ в перерізах зварних конструкцій після навантаження i розвантаження, залишкових вигинів, обгрунтування можливості вирівнювання конструкцій шляхом наплавлення зварних швів і оцінки впливу наслідків такого вирівнювання на несучу здатність сталевих елементів. Результати експериментальних досліджень дозволили обгрунтувати можливість вирівнювання експлуатованих конструкцій, які отримали пошкодження.

Результати досліджень застосовано при обгрунтуванні можливості подальшої експлуатації сталевих двотаврових колон, які отримали пошкодження під час експлуатації.

Аналіз останніх досліджень та публікацій. Робота конструкцій після підсилення надзвичайно складна i залежить від багатьох чинників як конструктивного, так i технологічного характеру. В першу чергу чинниками впливу на несучу здатність для сталевих конструкцій можуть бути $3 \mathrm{H}$, які виникають при виготовленні. Тому при розробці методів розрахунку таких конструкцій подібні обставини обумовлюють необхідність відмови від врахування другорядних чинників і внесення передумов, які спрощують розрахунок $[1,2]$. 
Вибір схеми підсилення сталевих стержневих конструкцій можна вважати багатоваріантним завданням. Враховуючи сучасний рівень розвитку методів розрахунку та проектування конструкцій, а також різноманіття можливих схем і прийомів підсилення, розробка загального підходу до завдань оптимізації представляється справою майбутнього. Рішення завдань оптимізації ускладнюється ще й тим, що основним критерієм оптимальності підсилення часто $\epsilon$ не економія матеріалу або зниження вартості комплексу робіт із підсилення, а забезпечення найбільшої його технологічності. При цьому під технологічністю розуміється не зручність проведення робіт, а можливість їх здійснення без зупинки виробництва в мінімальні терміни з метою зниження виробничих втрат [1].

Підсилення нарощуванням перерізу доцільно проводити для відносно рівних елементів. Забезпечення щільного прилягання елементу підсилення до конструкції яку підсилюють, з подальшим зварюванням дозволяє забезпечити надалі надійну роботу складеного перерізу i, навпаки, приварювання елементу підсилення до зігнутої конструкції може звести нанівець весь очікуваний ефект.

Через все вищевикладене передбачається, що йдеться про розрахунок i застосування підсилення конструкції за цілком певною схемою із заздалегідь заданими параметрами і при відомих впливах на неї. Зокрема, наявність ЗНС, який обумовлено зварюванням та іншими видами локальних термічних впливів (наприклад, при вирівнюванні зварюванням) сприятиме збільшенню або зменшенню несучої здатності, а значить і збільшенню або зменшенню терміну служби (ресурсу) конструкції. Підтвердженням правомірності прийнятої схеми підсилення або вирівнювання конструкцій можуть бути тільки результати експериментальних досліджень.

Мета. Метою проведених досліджень було експериментальне визначення несучої здатності сталевих конструкцій після навантаження, розвантаження, вирівнювання під пресом або шляхом наплавлення холостих валиків на опуклих кромках і подальшого навантаження.

Матеріали та методика дослідження. Методика дослідження - експериментальна. В ході проведення досліджень розроблено методику, виготовлено оснащення, підготовлено експериментальні зразки і прилади, виконано дослідження експериментальних зразків за розробленою методикою, отримано і оброблено отримані результати експериментальних досліджень.

Як зразки для експериментального вивчення несучої здатності сталевих елементів після навантаження, розвантаження, вирівнювання шляхом наплавлення холостих валиків $\mathrm{i}$ подальшого навантаження були прийняті експериментальні зразки, які були випробувані на стійкість $[2,3]$. Вони були виготовлені шляхом розпилювання прокатних двотаврів №12 за ГОСТ 8239-89 на мірні довжини: 800, 1200 і 1400 мм.

Всього було виготовлено 3 серії по 4 зразки в кожній [2]. В межах серії кожен зразок мав різну довжину наплавленого шва в центральній частині, а саме 0,2, 0,4 і 0,6 довжин елементу. Окрім цього, в першій і третій серіях були використані зразки без наплавлених валиків, тобто без регулювання ЗНС (контрольні зразки). Зразки завдовжки 800 мм і 1200 мм було виготовлено з однієї партії металу. Зразки завдовжки 1400 мм було виготовлено з двох партій металу: в зразках першої партії довжина наплавленого валика була 0,2 і 0,4 довжин елементу, а в зразках другої партії - 0,6 довжини елементу і без наплавлення. Два зразки 3 металу першої партії завдовжки 600 мм було призначено для визначення ЗНС в перерізах до і після наплавлення валиків на частини довжини [3]. Регулювання ЗНС було виконано в середній частині довжини елементів шляхом наплавлення валиків по кромках поясів. Наплавлення валиків виконане напівавтоматом в середовищі вуглекислого газу. Для цього було використано зварювальний дріт діаметром 0,8 мм, сила струму $90 \mathrm{~A}$, вид струму постійний. Відхилення по довжині елементів не перевищували \pm 5 мм.

Для виконання поставлених задач при випробуваннях зразків двотаврового перерізу на стійкість в площині меншої жорсткості було запроектовано і виготовлено відповідне оснащення і знімні опорні пристосування, за допомогою яких виявилося можливим виконати 
центрування елементу або створити заданий ексцентриситет. Випробування проводилися 3 ексцентриситетом 10 мм. Такий ексцентриситет прийнятий з метою контролю напрямку вигину при додатку навантаження. Лінійні переміщення зразків визначалися індикаторами годинного типу ІЧ-10 в двох горизонтальних напрямках у верхньому і нижньому закріпленні. У центрі для визначення переміщень було встановлено три прогиноміри ПАО-6, в т.ч. один для виміру переміщень в площині меншої жорсткості, і два - в площині більшої жорсткості по двох сторонах елементу. Показання тензорезисторів опору знімалися за допомогою системи СIIT-3.

Проведення випробувань кожного зразка виконувалося в такій послідовності [2]:

- зразок встановлювався в початкове положення;

- за допомогою індикаторів ІЧ-10 виставлявся ексцентриситет додатка навантаження;

- виконувалося знімання початкових показань по приладах ПАО-6 і CIIT-3 без навантаження;

- зразок завантажувався початковим навантаженням для перевірки працездатності приладів і якості центрування;

- після перевірки працездатності приладів і якості центрування виконувалося поетапне навантаження 3 витримкою на кожному етапі. Для зразків серії Д-3 $(\lambda=111)$ навантаження виконувалося етапами по 800 кг до навантаження 8 т і далі етапами по 400 кг до втрати стійкості. Для зразків серій Д-1 $(\lambda=67)$ і Д-2 $(\lambda=96)$ навантаження виконувалося таким чином: перший етап 5 т, потім етапами по 2 т до навантаження 13 і 11 т (відповідно для зразків Д-1 і Д-2). Після досягнення величин 13 і 11 тонн етапне навантаження знижувалося і складало 1 тонну до втрати здатності, що несла;

- на кожному етапі вантаження знімалися свідчення по приладах;

- для контролю ходу експерименту за показниками ПАО-6 і шкали пресу будувався графік залежності «навантаження-прогин», а також будувалися епюри напружень в перерізах за даними CIIT-3 (переклад показань приладу в напруження було виконано за допомогою коефіцієнта тензочутливості, величину якого було визначено за результатами тарування на балці рівного опору);

- експеримент тривав до втрати зразком несучої здатності (як критерій вичерпання несучої здатності було прийнято зростання прогинів без збільшення навантаження);

- після закінчення експерименту для усіх зразків було виконано порівняння результатів для кожної серії і по усіх серіях в цілому.

Після проведених випробувань на стиск зразки були оглянуті й обміряні з метою визначення залишкових вигинів (рис. 1). Були відібрані зразки для випробувань на визначення ЗНС (найбільш деформовані зразки в кожній серії у кількості 1 шт.) руйнівним методом. Інші зразки були вирівняні шляхом наплавлення холостих валиків по розтягнутих кромках або за допомогою пресу (таблиця 1 [4]). Довжина зварного шва була визначена за методикою, викладеною в роботі [1]. Результати випробувань приведені в роботі [4].

Вирівнювання зразків було виконано шляхом наплавлення холостих валиків на опуклих кромках. Для кожного зразка було прийнято індивідуальну схему наплавлення валиків. Наплавлення валиків було виконане зворотньо-ступінчастим швом ділянками завдовжки не більше 150 мм. Для цього було використано зварювальний дріт діаметром 0,8 мм, сила струму 90А, вид струму - постійний, по аналогії з раніше виконаним наплавленням при виготовленні зразків.

Після вирівнювання частину зразків (по одному з кожної серії) було відібрано для випробувань на визначення ЗНС за методикою, яку викладено в роботах $[3,4]$. Інші зразки було вирівняно i випробувано на стійкість за методикою, яку було розроблено для досліджень зразків на стиск [3, 5]. Випробування проводилися з використанням тих же пристосувань i 3 тими ж ексцентриситетами, які були використані при первинних випробуваннях, тобто схема деформації зразка відповідала тій, яку наведено в роботі [2].

Результати досліджень. Результати випробувань приведені в таблиці 1 [5]. 


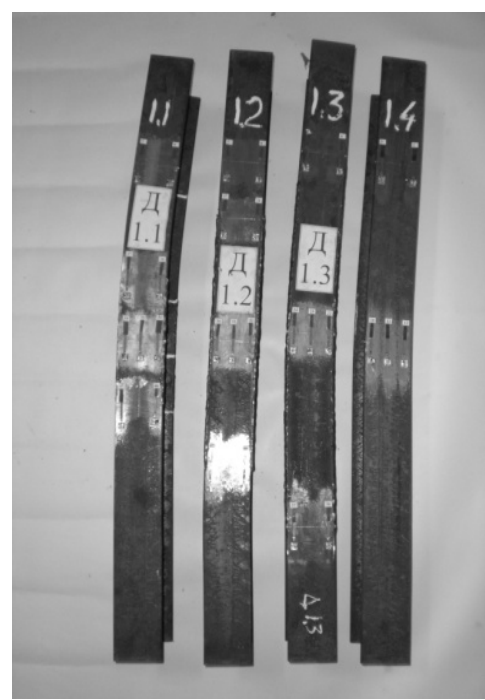

a)

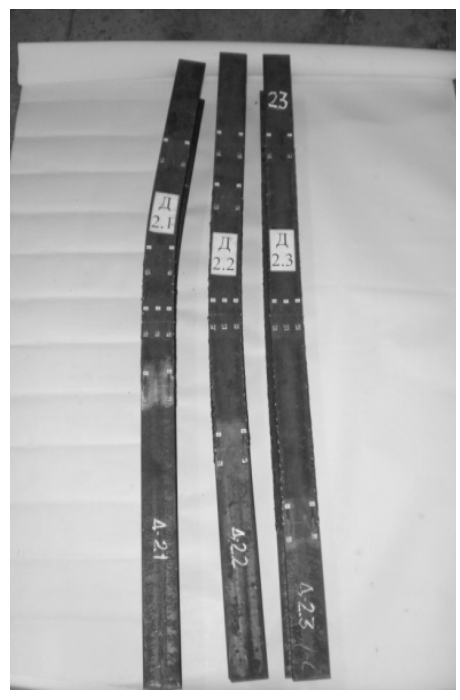

б)

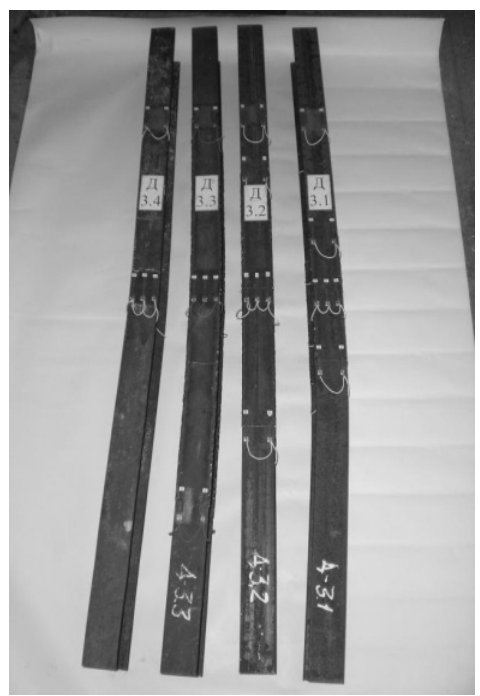

в)

Рис. 1. Загальний вигляд зразків після первинних випробувань на стиск:

а) - зразки серії Д-1;

б) - зразки серії Д-2;

в) - зразки серії Д-3

Таблиця 1 - Зіставлення величин несучої здатності

\begin{tabular}{|c|c|c|c|c|c|}
\hline \multirow{2}{*}{ Серія і номер зразка } & \multirow{2}{*}{$R_{y}^{f}, \mathrm{MПа}$} & $H, \mathrm{~cm}$ & $\lambda$ & \multicolumn{2}{|c|}{ Несуча здатність, кН } \\
\cline { 4 - 6 } & & & & $P_{u, 1}$ & $P_{u, 2}$ \\
\hline 1 & 2 & 3 & 4 & 5 & 6 \\
\hline Д-1.1/1 ДП (п) & 290 & 92,5 & 67 & 163 & 178 \\
\hline Д-1.3/3 ДП (п) & 292 & 92,5 & 67 & 178 & 198 \\
\hline Д-1.4/4 ДП (3) & 290 & 92,5 & 67 & 154 & 158 \\
\hline Д-2.2/6 ДП (п) & 290 & 132,5 & 96 & 135 & 160 \\
\hline Д-2.3/7 ДП (3) & 290 & 132,5 & 96 & 145 & 140 \\
\hline Д-3.2/9 ДП (3) & 280 & 152,5 & 111 & 121 & 144 \\
\hline Д-3.3/10 ДП (п) & 363 & 152,5 & 111 & 135 & 147 \\
\hline Д-3.4/11 ДП (3) & 369 & 152,5 & 111 & 127 & 120 \\
\hline
\end{tabular}

Примітки.

1. В позначеннях несучої здатності (стовпці 5,6$) P_{u, 1,} P_{u, 2}$ індекс 1 відповідає несучій здатності для зразків при первинному завантаженні, індекс 2 - несучій здатності зразків після вирівнювання.

2. В позначеннях (п) - вирівнювання за допомогою преса; (з) - вирівнювання за допомогою наплавлення холостих валиків

3 приведених матеріалів видно, що несуча здатність для більшості зразків після вирівнювання виявилася не нижчою, ніж несуча здатність зразків, яку отримано при початкових випробуваннях. Причому зразки, вирівнювання яких робилося під пресом, як $\mathrm{i}$ очікувалося, показали більшу несучу здатність, ніж зразки, які вирівнювалися шляхом наплавлення холостих валиків.

Результати проведених досліджень певною мірою були використані при обгрунтуванні можливості подальшої експлуатації сталевих колон секції $\mathrm{F}$ в осях 72-74/А-Б складського 
комплексу «Логістичний парк» ТОВ «Термінал Бровари» за адресою Об’їзна дорога, 62 в м. Бровари Київської обл. Будівля являє собою прямокутну в плані одноповерхову споруду 3 металевим каркасом, яка складається 3 окремих секцій. Загальний розмір секції $\mathrm{F}$, в якій розташовано колони, що отримали пошкодження за час експлуатації, в осях 65-77/А-Л становить 72-102 м. Фрагмент плану будівлі наведено на рис. 2.

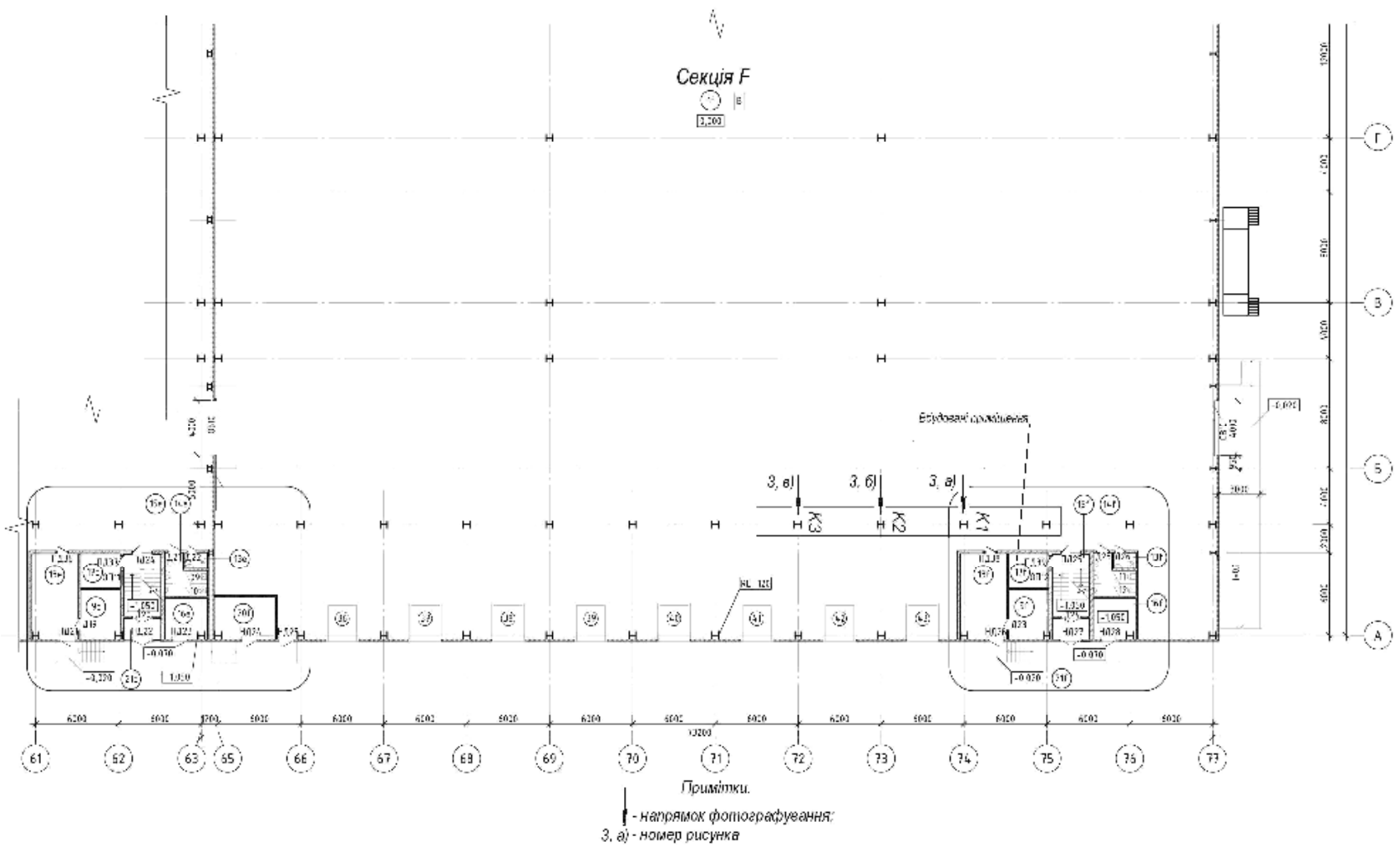

Рис. 2. Фрагмент плана будівлі (секції F)

Несучі колони розміщено по цифровим осям 65, 69, 73, 77 і літерним осям. Несучі балки покриття розміщено по літерним осям. Просторова жорсткість конструкцій будівлі забезпечується сумісною роботою сталевих колон, конструкцій покриття (балок, прогонів, в'язів), вертикальних в'язів між колонами в осях Д-Е, а також конструкцій вбудованого об'єму в осях 74-76/А-Б.

Складування матеріалів виконується на підлозі. Переміщення матеріалів в межах складського об'єму виконується транспортними засобами, які переміщуються по підлозі. Підвісний транспорт в будівлі відсутній.

Обстеження конструкцій було виконано після звільнення орендаторами приміщень, які розташовано в секції $\mathrm{F}$. Необхідність у проведенні робіт викликана тією обставиною, що в процесі експлуатації при переміщенні грузу транспортом, що переміщується по підлозі, виникли пошкодження колон у вигляді погнутості полиць або вм'ятин в полицях (таблиця В.1 [6], група 6, номер в середині групи 2).

Перерізи колон являють собою зварний двотавр (полиці: сталевий лист 420х10 мм; стінка: сталевий лист 390х10 мм). Згідно таблиці В.1 [6] (група 6, номер в середині групи 2) для конструкції, технічний стан якої є роботоспроможним, величина погнутості (вм'ятини) стиснутої полиці не повинна перевищувати $f \leq 0,6 \cdot t=0,6$ см (6 мм). Для колони К1 величина погнутості приблизно становила 10 мм, для колони К2 величина вм'ятини - 13 мм, для колони К3 - 10 мм.

Схему розміщення обстежуваних колон К1, К2, К3 наведено на рис. 2. Вигляд пошкоджень в опорних частинах конструкцій наведено на рис. 3. 


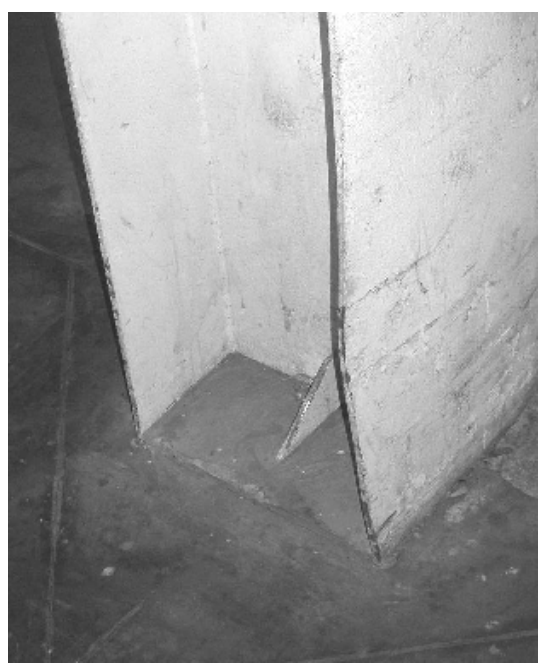

a)

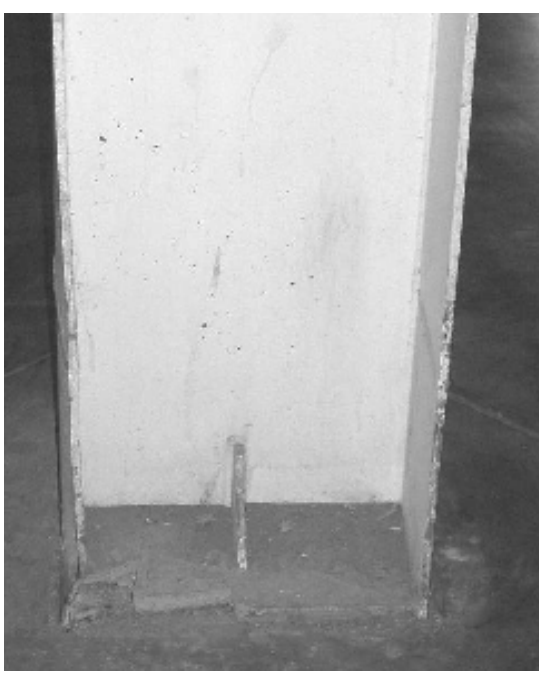

б)

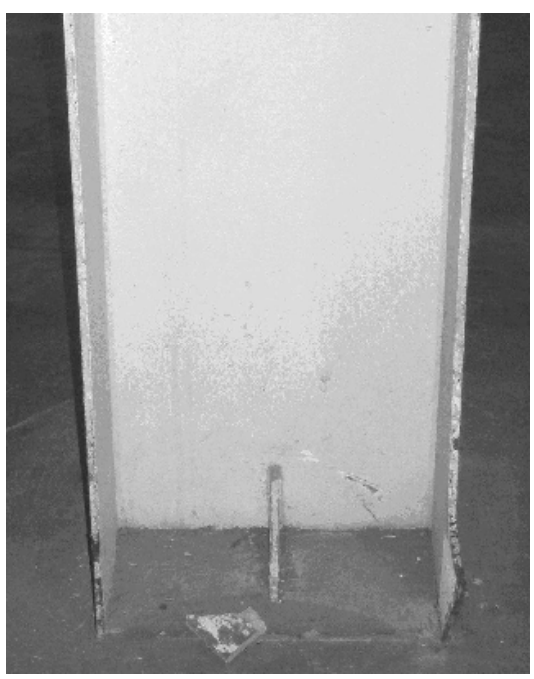

B)

Рис. 3. Загальний вигляд опорної частини колон К1, К2, К3 (рис. 2):

а) вигляд опорної частини колони К1;

б) вигляд опорної частини колони К2;

в) вигляд опорної частини колони К3

Було виконано розрахунки колон. Результати розрахунків дозволили встановити, що колони К1, К2, К3, в нижній частині яких є погнутості та вм'ятини в полицях, мають суттєвий запас міцності.

Згідно п. 6.5.10 [6] пошкодження колон відносяться до категорії $5_{\mathrm{d}}$, тобто це такі пошкодження, які не становлять в момент виявлення безпосередньої небезпеки для конструкцій, але в подальшому можуть викликати пошкодження інших елементів (вузлів, з'єднань) і при розвитку перейти до категорії $\mathrm{A}_{\mathrm{d}}$, тобто при подальшій експлуатації можливі, на додаток до існуючих, аналогічні пошкодження внаслідок ударів транспортом, що пересувається підлогою. До категорії $\mathrm{A}_{d}$ належать пошкодження особливо відповідальних елементів і з'єднань, які становлять безпосередню небезпеку для руйнування (пункт 2.9 [3]).

Технічний стан обстежуваних колон можна вважати непридатним до нормальної експлуатації, враховуючи, що за результатами розрахунку колони мають суттєвий запас міцності, але мають пошкодження, величини яких дещо перевищують нормативні обмеження (п. $5.3[6])$.

На підставі оцінки технічного стану та 3 метою недопущення появи аналогічних пошкоджень і переходу наявних пошкоджень до категорії $\mathrm{A}_{d}$ (п. 6.5 .10 [6]) рекомендується виконати наступне:

- виправити полиці двотаврового перерізу колон в місцях порушень за допомогою гідравлічних домкратів або аналогічних систем;

- 3 метою унеможливлювання появи при подальшій експлуатації аналогічних пошкоджень цих та інших колон виконати заходи щодо захисту нижньої частини всіх колон будівлі додатковими елементами, наприклад, шляхом замуровування важким бетоном класу за міцностю не нижче за С20/25 простору між полицями двотаврів в нижній частини колон (на висоту до 0,5 м, де можлива поява таких пошкоджень) або встановленням додаткових демпфуючих елементів.

Слід очікувати, що несуча здатність сталевих колон після вирівнювання не зміниться, враховуючи результати експериментальних досліджень. За розробленими рекомендаціями було виконано вирівнювання поличок колон за допомогою гідравлічних домкратів.

Висновки. В ході проведених випробувань зроблено такі висновки.

1. Розроблено методику досліджень несучої здатності сталевих двотаврових елементів після навантаження, розвантаження, подальшого вирівнювання і вторинного навантаження. В якості експериментальних використано зразки з різними видами регулювання залишкового 
напруженого стану, які були випробувані на первинний стиск. Після випробувань експериментальні зразки було вирівняно під пресом або шляхом наплавлення холостих валиків по опуклих кромках. Такі способи вирівнювання дозволили отримати зразки для вторинних випробувань на стиск з незначними вигинами.

2. Приведені результати експериментального визначення несучої здатності зразків після розвантаження і вирівнювання. Результати випробувань показали, що несуча здатність для більшості зразків після вирівнювання виявилася не нижчою, ніж несуча здатність при початкових випробуваннях. Причому зразки, вирівнювання яких робилося під пресом, як $\mathrm{i}$ очікувалося, показали більшу несучу здатність ніж зразки, які вирівнювалися шляхом наплавлення холостих валиків.

3. Певною мірою результати експериментальних досліджень були використані при обгрунтуванні можливості подальшої експлуатації сталевих колон секції $\mathrm{F}$ в осях 72-74/А-Б складського комплексу «Логістичний парк» ТОВ «Термінал Бровари» за адресою Об'їзна дорога, 62 в м. Бровари Київської обл. Колони мали в нижній частині яких є погнутості та вм'ятини в полицях. За результатами проведених досліджень було рекомендовано виконати виправлення полиць колон. Слід очікувати, що несуча здатність сталевих колон після вирівнювання не зміниться, враховуючи результати експериментальних досліджень.

\section{Література}

1. Голоднов, А. Регулирование остаточных напряжений в сварных двутавровых колоннах и балках, Киев: Сталь, 2008. 150 с.

2. Скребцов С. Результаты экспериментальных исследований устойчивости элементов из прокатных двутавров после регулирования остаточного напряженного состояния на части длины / С. Скребцов, А. Иванов, А. Голоднов. // Збірник наукових праць Українського інституту сталевих конструкцій імені В.М. Шимановського. - 2010. - №56. - С. 494-499.

3. Голоднов А. Определение остаточных напряжений в стальных конструкциях после разгрузки и выравнивания / А. Голоднов, С. Скребцов, Б. Иванов. // Современные строительные конструкции из металла и древесины. - 2013. - №17. - С. 95-102.

4. Голоднов А. И. Остаточные напряжения в стальных двутавровых элементах после разгрузки и выравнивания / А. И. Голоднов, Б. В. Иванов // Збірник наукових праць Українського інституту сталевих конструкцій імені В. М. Шимановського. - 2016. - Вип. 17. C. 95-102.

5. Голоднов А. И. Несущая способность стальных двутавровых элементов после разгрузки и выравнивания / А. И. Голоднов, Б. В. Иванов. // Збірник наукових праць Українського інституту сталевих конструкцій імені В.М. Шимановського. - 2016. - №19. - С. $32-42$.

6. Оцінка технічного стану сталевих будівельних конструкцій, що експлуатуються: ДСТУ Б В.2.6-210: 2016. - Офіц. вид. - К. : Мінрегіон України, 2016. - 53 с. - (Національний стандарт України).

\section{References}

[1] A. Golodnov, Regulirovanie ostatochny`kh napryazhenij v svarny`kh dvutavrovy`kh kolonnakh i balkakh, Kiev, Stal, 2008.

[2] S. Skrebczov A. Ivanov, A. Golodnov, Rezul'taty' e'ksperimental'ny'kh issledovanij ustojchivosti e`lementov iz prokatny'kh dvutavrov posle regulirovaniya ostatochnogo napryazhennogo sostoyaniya na chasti dliny', Zbi`rnik naukovikh pracz' Ukrayins 'kogo i'nstitutu stalevikh konstrukczi`j i’meni` V.M. Shimanovs`kogo, vol. 56, pp. 494-499, 2010.

[3] A. Golodnov, S. Skrebczov, B. Ivanov, Opredelenie ostatochny`kh napryazhenij v stal`ny`kh konstrukcziyakh posle razgruzki i vy`ravnivaniya, Sovremenny`e stroitel’ny`e konstrukczii iz metalla i drevesiny’, vol. 17. pp. 95-102, 2013. 
[4] A. I. Golodnov, B. V. Ivanov, Ostatochny`e napryazheniya v stal’ny`kh dvutavrovy`kh e`lementakh posle razgruzki i vy’ravnivaniya, Zbi`rnik naukovikh pracz' Ukrayins 'kogo i’nstitutu stalevikh konstrukczi`j i’meni` V. M. Shimanovs`kogo, Vol. 17, pp. 95-102, 2016.

[5] A. I. Golodnov, B. V. Ivanov, Nesushhaya sposobnost` stal`ny`kh dvutavrovy`kh e`lementov posle razgruzki i vy`ravnivaniya, Zbi`rnik naukovikh pracz' Ukrayins 'kogo i`nstitutu stalevikh konstrukczi`j i`meni` V.M. Shimanovs`kogo, vol. 19, pp. 32-42, 2016.

[6] Oczi`nka tekhni 'chnogo stanu stalevikh budi`vel’nikh konstrukczi`j, shho ekspluatuyut`sya: DSTU B V.2.6-210: 2016, K. : Mi`nregi’on Ukrayini, 2016.

\title{
ВЫРАВНИАПНИЕ СЖАТЫХ СТАЛЬНЫХ ДВУТАВРОВЫХ ЭЛЕМЕНТОВ ПОСЛЕ РАЗГРУЗКИ РАЛИЧНЫМИ СПОСОБАМИ
}

\author{
Голоднов А.И., д.Т.н., проф., \\ ООО «Укринсталькон им. В.М. Шимановского », г. Киев, Украина., \\ golodnow@ukr.net; ORCID: 0000-0002-9722-9164 \\ Иванов Б.В., инженер \\ ООО «МегаСП», г. Киев, Украина. \\ ivanov@megabp.com; ORCID: 0000-0002-9203-2987
}

\begin{abstract}
Аннотация. Выбор схемы усиления стальных стержневых конструкций считается многовариантным заданием. Современный уровень развития методов расчета и проектирования конструкций, многообразие возможных схем и приемов усиления позволяют разработать общий подход к задачам оптимизации усиления стальных конструкций.
\end{abstract}

Все это предусматривает расчет и проектирование усиления конструкций по определенной схеме с наперед заданными параметрами и при известных воздействиях. Подтверждением правомерности принятой схемы усиления или выравнивания конструкций могут быть только результаты экспериментальных исследований.

Изложена методика исследований несущей способности стальных двутавровых элементов после первичного нагружения, разгрузки, последующего выравнивания и вторичного нагружения. В качестве экспериментальных использованы образцы с различными видами регулирования остаточного напряженного состояния. После испытаний на первичное сжатие экспериментальные образцы были выровнены под прессом или путем наплавки холостых валиков по выпуклым кромкам.

Приведены результаты экспериментального определения несущей способности образцов после разгрузки и выравнивания. Результаты испытаний показали, что несущая способность для большинства образцов после выравнивания оказалась не ниже, чем несущая способность образцов, полученная при первичных испытаниях.

Результаты исследований использованы при обосновании возможности дальнейшей эксплуатации колонн складского здания. Необходимость в проведении работ вызвана тем обстоятельством, что в процессе эксплуатации при перемещении грузов транспортом по полу возникли повреждения отдельных колонн в виде погнутостей полок или вмятин в полках. Для трех колонн величины погнутостей превышали предельно допустимые величины.

По результатам расчетов установлено, что наиболее нагруженная колонна, в нижней части которой есть вмятина в полке, имеет существенный запас прочности.

Были разработаны рекомендации по обеспечению длительной и безопасной эксплуатации колонн. Для этой цели предложено выполнить выравнивание полок с помощью гидравоических домкратов. Усиление конструкций было выполнено в натуре.

Ключевые слова: сжатые элементы, первичное нагружение, разгрузка, выравнивание, вторичное нагружение, несущая способность. 


\title{
FLATTENING OF COMPRESSION STEEL DOUBLE-T MEMBERS AFTER UNLOADING BY VARIOUS MEANS
}

\author{
Holodnov O., Doctor of Technical Sciences, prof., \\ LLC “V. Shimanovsky Ukrainian Institute of Steel Construction”, Kyiv, Ukraine, \\ golodnow@ukr.net; ORCID: 0000-0002-9722-9164 \\ Ivanov B., engineer \\ MegaBP LLC, Kyiv, Ukraine. \\ ivanov@megabp.com; ORCID: 0000-0002-9203-2987
}

\begin{abstract}
Choice of arrangement for steel bar system reinforcing is considered a multivariate task. The current development level of methods for calculating and designing structures, the variety of possible arrangements and reinforcement methods allow to develop a general approach to problems concerning reinforcement optimizing of steel structures.

All this envisages calculation and design of structural reinforcement according to a certain arrangement with predetermined parameters and under known influences. Only experimental results are able to confirm validity of the adopted arrangement for strengthening or flattening of structures.

The methods for research of steel double-T members bearing resistance after primary loading, unloading, subsequent flattening and secondary loading are described. Samples of various types of residual stress state control were used as experimental ones. After primary compression testing, the experimental samples were flattened by press or by means of idler spindle beading along bulging edges.

The results of experimental determination of samples bearing resistance after unloading and flattening are presented. The test results displayed that the bearing resistance of the most samples after flattening was no lower than the samples bearing capacity obtained during initial tests.

The research results were used to justify possible further operation of the warehouse building columns. The need for work is caused by the fact that during operation, when moving goods on the floor, damage occurred to individual columns in form of bent flanges or dents in the flanges. For three columns, the curvature exceeded the maximum permissible values.

It was found according to the calculation results, that the most loaded column, with a dent in the flange in its lower part, had a significant margin of safety.

Guidance for ensuring the long and safe operating life of columns is developed. For this purpose, it was proposed to flatten the flanges by means of hydraulic jacks. Reinforcement of structures was executed on location.
\end{abstract}

Key words: compression members, primary loading, unloading, flattening, secondary loading, bearing resistance 


\title{
ФАКТОРНАЯ ОЦЕНКА ЭНЕРГОЭФФЕКТИВНОГО КОНСТРУКТИВНО- ТЕХНОЛОГИЧЕСКОГО РЕШЕНИЯ ИЗ ТЕРМОПРОФИЛЯ ЛСТК
}

\author{
Дмитриева Н.В., к.Т.Н., доцент, \\ Одесская государственная академия строительства и архитектуры \\ dmitrieva.nv76@gmail.com ORCID ID: 0000-0002-4828-1644
}

Агафонова И.П., старший преподаватель, Бендерский филиал ПГУ им. Т.Г.Шевченко barkaririna@bk.ru ORCID ID: 0000-0003-4330-2642

Аннотация. В статье рассмотрены особенности и преимущества, инновационных конструктивно-технологических решений в строительстве и реконструкции с использованием легких металлических конструкций. Приведены исследования основных энергетических проблем городов Украины, на примере г. Одесса. Охарактеризованы объемно-планировочные и конструктивные особенности проекта коттеджного поселка в с. Лески Одесской области. Представлена методика оптимизации конструктивнотехнологических решений, основанная на факторной оценке вариантов решения возведения каркаса коттеджей поселка с учетом энергоэффективности. В исследовании были выделены основные факторы, влияющие на выбор строительных материалов.

Ключевые слова: металлические конструкции, ЛСТК, энергоэффективность, факторная оценка, модульное строительство.

Введение. Проблема энергосбережения на рубеже тысячелетий превратилась в одну из важнейших общечеловеческих проблем. Рациональное и экономное использование природных ресурсов, сокращение вредных выбросов в атмосферу и эффективное использование электрической и тепловой энергии приобретают исключительно важное значение в современном обществе.

Необходимость повышения уровня энергетической безопасности является одной из главных задач нашего государства на современном этапе ее социально-экономического развития.

Украина удовлетворяет свои потребности в природных энергоресурсах за счет собственной их добычи приблизительно на 45\%. В большинстве стран мира уровень энергетической самообеспеченности такой же или даже более низкий. Проблема заключается в другом - недопустимо низкой эффективности использования топливно-энергетических ресурсов (ТЭР).

Появление новых инновационных технологий в строительстве совместно с развитием металлургии делают металл одним из наиболее перспективных материалов будущего.

В настоящее время в мировой практике особое внимание уделено использованию легких строительных конструкций из тонкостенных холодногнутых оцинкованных профилей (ЛСТК).

Широкое распространение конструкций из тонкостенного профиля в Украине затруднено в значительной мере из-за несовершенства отечественных нормативных и методических баз по расчету ЛСТК, отсутствия надлежащих инструкций по монтажу и эксплуатации, достаточного опыта проектирования подобных конструкций. На территории Украины, основной действующий документ, регламентирующий использование, проектирование конструкций из стальных тонкостенных профилей является ДСТУ-Н Б В.2.6-87:2009 «Проектирование конструкций с применением стальных тонкостенных профилей». Приложение А ДСТУ-Н Б В.2.6-87:2009 содержит номенклатуру сечений для тонкостенных профилей и укороченный сортамент профилей из холодногнутой оцинкованной стали. В то же время существуют зарубежные нормы и стандарты для 
проектирования подобных конструкций, такие как Еврокод-3 и AJSJ[1], на которые целесообразно полагаться.

Несмотря на очевидные преимущества использования профилей ЛСТК [2], существует также ряд эксплуатационных недостатков. Основным недостатком является нарушение комфортного режима микроклимата в помещениях, которое возникает из-за наличия многочисленных теплопроводящих включений в наружных оболочках, так называемых «мостиков холода». Образование влаги наблюдается в местах расположения профилей, приводящих к появлению плесневых грибов. В значительной степени теплопроводные включения в течение отопительного периода приводят к потере тепла в окружающую среду, что напрямую влияет на оплату коммунальных услуг в отопительный сезон [3].

Анализ последних исследований и публикаций. Политика энергосбережения в Европе практически реализуется в принятой Европарламентом и Советом ЕС в 2002г. директиве 2002/91/EC «Energy Performance of Building» (EPBD). В соответствии с Директивой, существенно ужесточаются требования к экономии энергии в зданиях.

Директива EPBD предусматривает принятие странами-членами ЕС общих решений, включающих: единую методику расчета эффективности здания с точки зрения энергопотребления; минимальные нормы потребления энергии для всех новых и реконструируемых старых крупных зданий; систему сертификации зданий, регламентирующую количество потребляемой энергии и, соответственно, энергоэффективность здания [4].

Согласно разработанной концепции энергоэффективного здания компанией Сен-Гобен ISOVER при проектировании соблюдаются несколько основополагающих архитектурных и строительных принципов [5].

Принципы повышения энергоэффективности:

- оптимизация архитектурных форм здания с учетом возможного воздействия ветра;

- оптимальное расположение здания относительно солнца, обеспечивающее возможность максимального использования солнечной радиации;

- увеличение термического сопротивления ограждающих конструкций здания (наружных стен, покрытий, перекрытий над неотапливаемыми подвалами) до технически возможного максимального уровня;

- сведение к минимуму количества и тепловой проводимости, имеющихся в конструкции тепловых мостов;

- обеспечение необходимой воздухоплотности конструкции здания относительно притока наружного воздуха;

- повышение до максимального технически возможного уровня термического сопротивления светопрозрачных ограждающих конструкций;

- создание системы вентиляции для подачи свежего воздуха, удаления отработанного воздуха, распределения тепла в помещении и организация регенерации тепла вентиляционного воздуха.

Сочетание указанных выше факторов обеспечивает минимальное энергопотребление здания, при этом определяющими факторами повышения энергоэффективности оболочек в зданиях и сооружениях являются увеличение термического сопротивления его конструктивных элементов и сокращение количества тепловых мостов. Решение этих задач в настоящее время как никогда актуальна и требует разработки мер для ее решения.

Решению теоретических, технических и практических проблем при проектировании и строительстве зданий из ЛСТК профиля посвящены работы такие ученые, как: Ватин Н.И., Синельников А.С., Зинкевич О.Г., в которых освещены вопросы комплексного сравнения стен «каркасных» и «бескаркасных» конструкций и методики рационального проектирования каркасов из ЛСТК.

Постановка проблемы. Оценивая возможность применения предложенной концепции в Украине, необходимо отметить следующее. Основными потребителями ЛСТК традиционно являются представители промышленного и коммерческого сегментов. 
Активное использование ЛСТК в жилом, и особенно - в коттеджном строительстве сдерживается неготовностью потребителей к широкому использованию металла. Заказчикам индивидуального жилья вообще присущ некоторый консерватизм и даже косность в выборе технологий и материалов. Преимущества ЛСТК для этого сегмента неочевидны и требуют дополнительной аргументации. Для этого на примере проектировании коттеджного поселка из термопрофиля ЛСТК разработана методика факторной оценки выбора рационального конструктивно-технологического решения.

Срок окупаемости такого здания в Украине будет очень большим, что и будет определять возможность его реализации в нынешних экономических условиях. Таким образом, для Украины эта концепция на сегодняшний день не является экономически оптимальной. Это - дома будущего. Вместе с тем, уже сегодня в отечественной практике может быть использована значительная доля из предлагаемых в этом проекте технических решений, направленных на повышение энергоэффективности зданий, например, путем использования легких стальных тонкостенных конструкций (термопрофилей).

Целью данной статьи является рассмотрение выбора конструктивно-технологического решения энергоэффективности коттеджных поселков путем аргументации на основании факторной оценки.

Материалы и методика исследования. Учитывая актуальность развития производство гнутых профилей из оцинкованной стали на протяжении последнего десятилетия, в Украине создан Украинский центр стального строительства (УЦСС), объединяющий более 10 компаний, работающих на рынке металлоконструкций.

ЛСТК стал альтернативой применения таких конструкций, как железобетон, кирпич, дерево или стальной прокат на основании значительного экономического эффект в вышеприведенной области строительства благодаря снижению нагрузок от собственного веса и сейсмических нагрузок, уменьшению транспортных расходов и затрат на монтаже, сокращению сроков строительства без применения строительных машин.

Критерии выбора имеют многоуровневый подход, который предполагает решение многочисленных задач: технических, технологических, эксплуатационных, экономических и экологических.

В исследованиях были выбраны следующие критерии определяющие технологичность работы - трудоемкость и скорость монтажа материала с наименьшим количеством отходов, удобство резки материала, транспортабельность, устройство без специального оборудования и высококвалифицированных рабочих и т.д. Также при выборе учитывалась совокупность таких критериев, как влагостойкость, звукоизоляция, биологическая и химическая инертность, огнестойкость, ремонтопригодность, долговечность, экологичность и стоимость.

Методика факторной оценки включала в себя выбор наиболее подходящего материала конструкции стен с использованием качественных и количественных критериев.

К качественным критериям относятся: возможность всесезонного монтажа; экологичность; пожаробезопасность.

К количественным критериям относятся: стоимость строительства; минимальная толщина стены (без учета утеплителя); морозоустойчивость; шумоизоляция; продолжительность строительства; долговечность; коэффициент теплопроводности.

При отборе альтернатив и определения оценки критериев использовался коммуникативный индивидуальный метод - когда варианты решений генерирует единственный эксперт. После специалистом экспертом определялись степень весомости того или иного фактора путем количественной оценки каждого критерия.

Мониторинг рынка строительных технологий, которые наиболее востребованы на территории Украины и СНГ для строительства каркасных конструкций коттеджного поселка, было отдано предпочтение следующим основным материалам: бетон, керамзитобетон, силикатный кирпич, пенобетон, газобетон, брус, деревянный каркас, ЛСТК.

Строительство планируется к северо-востоку от г. Одессы, с. Лески, на берегу Черного моря, на отведенном участке размерами в плане 450 х 300 м. Концепция проекта 
предусматривает строительство коттеджного поселка из 56 индивидуальных коттеджей, объемно-планировочным решением двух типов коттеджей: Тип 1 - размерами в осях: 1-5 (11.3 м) и А-Г (10.3 м) и высотой помещения в максимальной точке - 3.7 м (рис. 1); Тип 2 размерами в осях: $1-5(12,0$ м) и А-Д (17.2 м) и высотой помещения в максимальной точке $3.8 \mathrm{M}$.

В основе концепции поселка - сочетание особенностей природного ландшафта и нестандартных для загородного проекта архитектурных решений. Современную архитектуру дополняет панорамное остекление, взятое из практики высокотехнологичного высотного строительства. Это позволит создать просторные, глубокие внутренние зоны без ущерба для комфорта жителей (коэффициент соотношения ширины и глубины помещений 2,00-1,63).
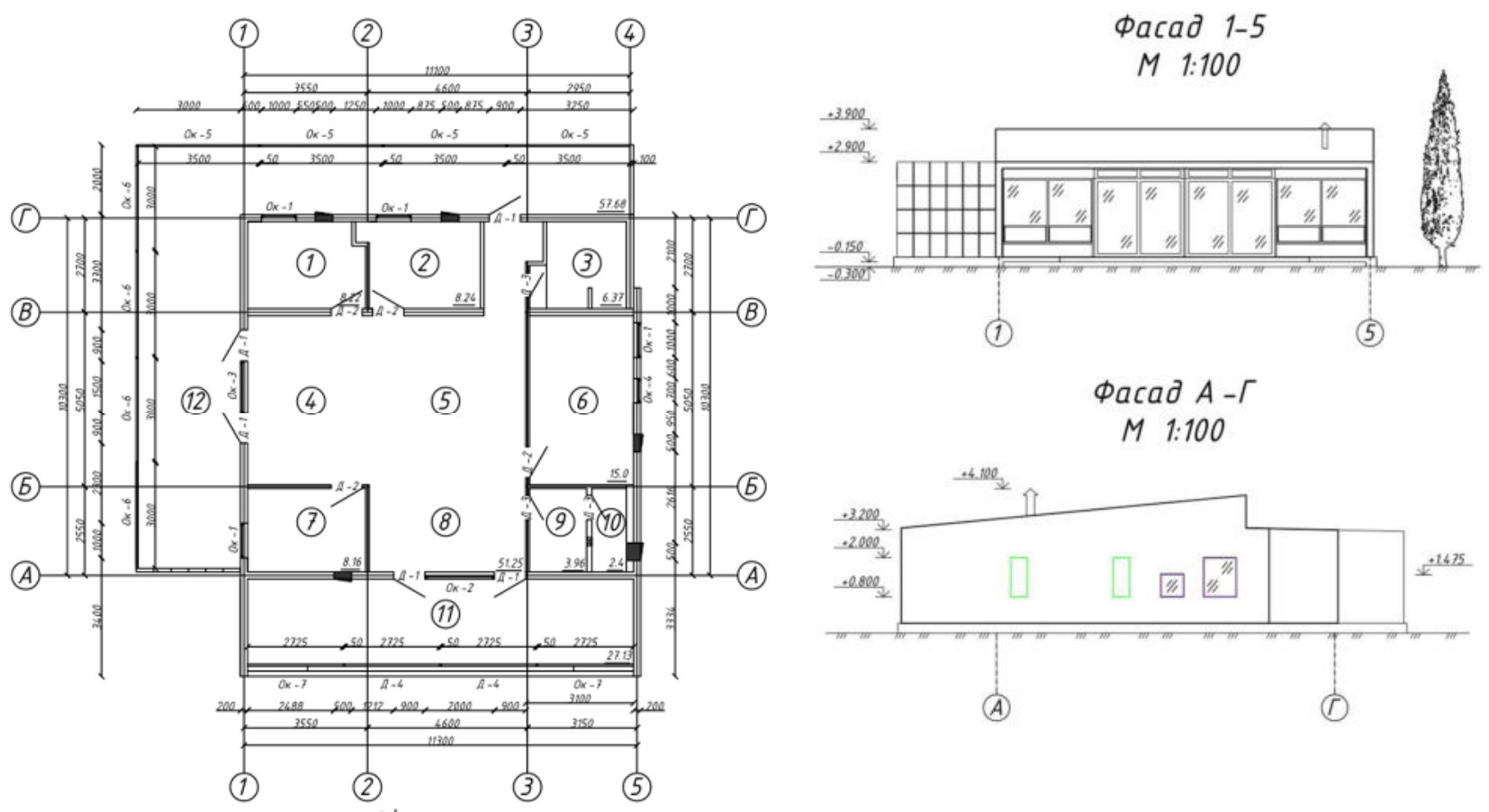

Фacad $A-\Gamma$ M 1:100

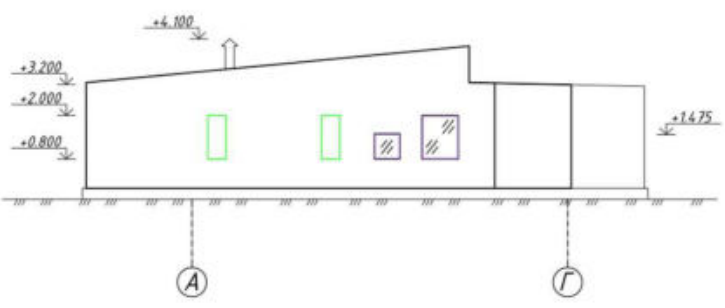

Рис. 1. Объемно-планировочное решение коттеджа Тип 1: План на отметке 0.000и и фасады 1-5 и А-Г

Конструктивные решения несущих наружных и внутренних стен приняты следующие: стеновые панели из термопрофиля, толщиной 200 мм с плитным утеплителем Superrock, с обшивкой снаружи виниловым сайдингом, а изнутри листами ОСП и листами гипсокартона и внутренние - стеновые панели из термопрофиля, толщиной 200 мм со звукоизоляцией из плитного утеплителя Rockton, с обшивкой с двух сторон листами ОСП и листами гипсокартона.

Перегородки - каркас собирается из термопрофиля, толщиной 100 мм со звукоизоляцией из плитного утеплителя Rockton, с обшивкой листами ОСП и листами гипсокартона.

Несущим элементом крыши принята согласно расчетам металлическая ферма. Каркас фермы (рис.2) выполняется из термопрофиля, с плитным утеплителем Rockmin Plus. Решетчатая ферма изготавливается из С-образных профилей с отгибами полок, изготовленных из стали марки S350 с цинковым покрытием Z275 в соответствии со стандартом EN 10346. Для верхнего и нижнего поясов, а также раскосов принято одинаковое сечение. $10^{\circ}$.

Покрытие кровли выполнено из профнастила Ruukki RAN-20B. Угол наклона крыши 


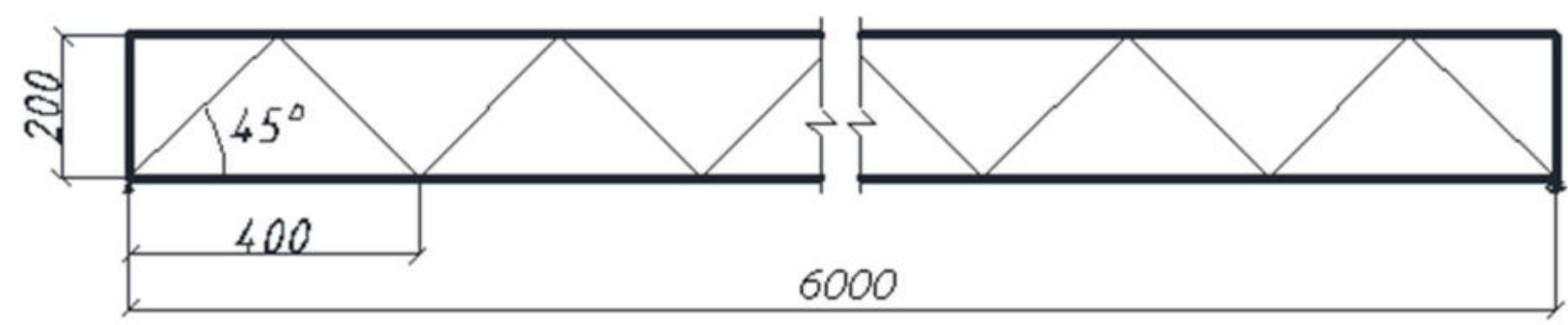

Рис. 2. Геометрическая схема фермы

Для предварительного анализа на основании экспертной оценки имеющейся технической информации была составлена таблица сравнения материалов для возведения каркаса коттеджа по выбранным критериям (таблица 1.).

Таблица 1 -Технологические характеристики строительных материалов

\begin{tabular}{|c|c|c|c|c|c|c|c|c|}
\hline $\begin{array}{c}\text { Наименование } \\
\text { факторов }\end{array}$ & Бетон & $\begin{array}{l}\text { Керамзи } \\
\text {-тобетон }\end{array}$ & $\begin{array}{l}\text { Кир- } \\
\text { пич }\end{array}$ & $\begin{array}{l}\text { Пено } \\
\text { бетон }\end{array}$ & $\begin{array}{l}\text { Газо- } \\
\text { бетон }\end{array}$ & Брус & $\begin{array}{l}\text { Деревя } \\
\text { н- ный } \\
\text { каркас }\end{array}$ & $\begin{array}{c}\text { ЛСТ } \\
\text { К }\end{array}$ \\
\hline $\begin{array}{c}\text { Возможность } \\
\text { всесезонного монтажа }\end{array}$ & Да & Да & Да & Да & Да & Да & Да & Да \\
\hline Экологичность & Да & Нет & Да & Нет & Да & Да & Нет & Да \\
\hline Пожаробезопас-ность & Высокая & Средняя & Высокая & Средняя & Средняя & Низкая & Низкая & Высокая \\
\hline $\begin{array}{l}\text { Коэффициент } \\
\text { теплопроводности, } \\
\text { Вт/(м*C) }\end{array}$ & 1,51 & 0,66 & 0,87 & 0,21 & 0,14 & 0,18 & 0,05 & 0,045 \\
\hline Долговечность, лет & 100 & 80 & 80 & 50 & 50 & 20 & 20 & 50 \\
\hline $\begin{array}{l}\text { Стоимость } \\
\text { строительства коттеджа } \\
\text { Тип1 тыс. грн. }\end{array}$ & 216,3 & 136,5 & 327,5 & 91,2 & 100 & 175 & 120 & 25 \\
\hline $\begin{array}{l}\text { Продолжитель-ность } \\
\text { строительства, мес }\end{array}$ & 7 & 6 & 12 & 6 & 6 & 6 & 4 & 3 \\
\hline $\begin{array}{l}\text { Морозостойкость, кол- } \\
\text { во циклов }\end{array}$ & 60 & 50 & 30 & 35 & 25 & 25 & 40 & 50 \\
\hline Шумоизоляция, дБА & 70 & 70 & 40 & 40 & 40 & 60 & 40 & 60 \\
\hline $\begin{array}{l}\text { Толщина стены без } \\
\text { утеплителя, м }\end{array}$ & 1,44 & 1 & 2,5 & 0,63 & 0,8 & 0,56 & 0,2 & 0,15 \\
\hline
\end{tabular}

Источник: разработка автором по источнику [6].

Первый этап анализа - ранжирование по степени значимости материалов конструкции стен, на основании сведений представленных в таблице 1. Критерии 1 и 2 не являются значимыми при выборе материалов, потому что, 1-ый критерий при использовании дополнительных приспособлений становиться одинаков для всех материалов, а 2-ой не влияет на качество используемых материалов, поэтому могут не учитываться при построении аналитических диаграмм. Третий критерий был переведен из качественных показателей в количественные, путем присвоения ему баллов за пожаробезопасность по шкале от 1 до 10.

Количественная оценка показателей 4 - 10 производилась экспертным методом на основании анализа имеющихся технических документов.

Сведем все критерии к единой бальной системе, расположив их в порядке важности каждого из них. Оценка технологий по количественным критериям производится по пятибалльной шкале, где минимальным и максимальным значениям присвоены баллы 1 и 5 
соответственно. Остальные баллы посчитаны с помощью интерполяции и представлены в таблице 2.

Таблица 2 - Факторная оценка конструктивно-технологических решений

\begin{tabular}{|l|c|c|c|c|c|c|c|c|}
\hline & $\begin{array}{c}\text { Сили- } \\
\text { катный } \\
\text { кирпич }\end{array}$ & $\begin{array}{c}\text { Пено } \\
\text { бетон }\end{array}$ & $\begin{array}{c}\text { Газо- } \\
\text { бетон }\end{array}$ & $\begin{array}{c}\text { Моно } \\
- \text { лит }\end{array}$ & $\begin{array}{c}\text { Керамзи- } \\
\text { то бетон }\end{array}$ & Брус & $\begin{array}{c}\text { Деревян- } \\
\text { ный каркас }\end{array}$ & ЛСТК \\
\hline Звукоизоляция & 5 & 5 & 5 & 5 & 4 & 5 & 3 & 4 \\
\hline Надежность & 5 & 3 & 3 & 4 & 3 & 4 & 4 & 5 \\
\hline $\begin{array}{l}\text { Теплоизоляционные } \\
\text { свойства }\end{array}$ & 1 & 4 & 4 & 4 & 3 & 5 & 5 & 5 \\
\hline Влагопоглощение & 2 & 3 & 2 & 3 & 3 & 5 & 5 & 3 \\
\hline Морозостойкость & 1 & 2 & 3 & 4 & 5 & 3 & 3 & 5 \\
\hline $\begin{array}{l}\text { Стоимость } \\
\text { строительства }\end{array}$ & 1 & 4 & 4 & 2 & 4 & 3 & 3 & 5 \\
\hline $\begin{array}{l}\text { Удобство } \\
\text { транспортировки }\end{array}$ & 1 & 3 & 3 & 1 & 4 & 2 & 3 & 3 \\
\hline $\begin{array}{l}\text { Необходимая } \\
\text { толщина стены (без }\end{array}$ & 1 & 3 & 3 & 4 & 3 & 4 & 4 & 5 \\
\hline $\begin{array}{l}\text { Птеплителя) } \\
\text { стростота }\end{array}$ & 1 & 5 & 5 & 2 & 3 & 2 & 3 & 4 \\
\hline Глубина фундамента & 1 & 2 & 2 & 4 & 1 & 3 & 4 & 5 \\
\hline Срок службы здания & 5 & 4 & 4 & 5 & 4 & 4 & 4 & 4 \\
\hline Экологичность & 5 & 5 & 2 & 2 & 4 & 5 & 3 & 4 \\
\hline $\begin{array}{l}\text { Пожаробез- } \\
\text { опасность }\end{array}$ & 5 & 4 & 4 & 5 & 4 & 2 & 2 & 5 \\
\hline Усадка & 2 & 2 & 4 & 4 & 4 & 3 & 4 & 5 \\
\hline $\begin{array}{l}\text { Длительность } \\
\text { строительства }\end{array}$ & $\mathbf{3 7}$ & $\mathbf{5 3}$ & $\mathbf{5 2}$ & $\mathbf{5 1}$ & $\mathbf{5 2}$ & $\mathbf{5 3}$ & $\mathbf{5 4}$ & $\mathbf{6 7}$ \\
\hline Итого баллов & 1 & 4 & 2 & 3 & 3 & 4 & 5 \\
\hline
\end{tabular}

Источник: [6].

Таким образом, исходя из данных оценки факторов, наибольшее количество баллов набрала технология ЛСТК - 67 баллов, наименьшее - силикатный кирпич - 37 баллов.

Анализ факторов позволил выделить конструктивно-технологические решения из бетона и силикатного кирпича. Оба материала имеют наибольшую стоимость и наибольшую продолжительность выполнения полного комплекса работ. При этом эти два решения имеют наименьший показатель сопротивления теплопотери среди всех, что является ключевым критерием энергоэффективности.

Также стоит отметить, что конструктивно-технологическое решение из бруса является наиболее дорогостоящим вариантом, и обладает наименьшей пожаробезопасностью и долговечностью. Так же и керамзитобетон хоть и обладает наибольшей долговечностью, имеет наименьшее сопротивление теплопотери и наибольшею продолжительность строительства.

Пенобетон и газобетон имеют неплохой коэффициент теплопроводности, но их продолжительность и стоимость строительства больше чем у деревянного каркаса или ЛСТК. 
Как видно из таблицы 1 решение из деревянного каркаса уступает решению из ЛСТК по долговечности (меньше на 30 лет), пожаробезопасности и стоимости, которая превышает в 1,6 раз стоимость возведения каркаса из ЛСТК.

Кроме этого хотелось бы отметить еще ряд критериев, которые играют не маловажную роль при выборе конструктивного решения. Применение термопрофиля ЛСТК оправдано малым весом металлоконструкций и их хорошей несущей способностью, легкой обработкой, минимальными значениями нагрузок на фундамент, а так же технологичностью и отсутствием потребности в грузоподъемной технике.

А недостатки ЛСТК возможно решить дополнительными мероприятиями. Например, влияние тепловых мостов возможно уменьшить двумя способами: использование двойных каркасов или использование наружных систем утепления, что учтено при проектировании данного проекта. Повышения предела огнестойкости ЛСТК, обеспечивается одним из способом: напыление и окраска различными огнестойкими материалами; облицовка гипсокартоном; оштукатуривание. Необходимость обязательной установки ветрозащиты и паронепроницаемого барьера обеспечит герметичности здания по отношению к ветру, к воздуху и к миграции пара через конструкцию, которое существенно влияет на энергопотребление, функционирование вентиляции и внутренний комфорт помещений[7].

Выводы и предложения. Благодаря факторной оценке конструктивнотехнологических решений по основным параметрам определено, что значительный экономический эффект, достигаемый снижением нагрузок от собственного веса конструкций, уменьшением расходов на транспорт и монтаж, сокращением сроков строительства без использования тяжелой техники, позволяет во первых аргументировать проектное решение строительства коттеджного поселка, во вторых дальнейшее перспективное развитие данной отрасли. Технология ЛСТК открывает возможности решения вопросов, касающихся строительства комфортабельного энергоэффективного жилья. Несмотря на то, что большинство в настоящий момент отдают предпочтение домам из кирпича, дерева или панелей, мировая практика и факторная оценка данного исследования свидетельствует, что инновационные технологии, к которым относится и ЛСТК, приносят неоспоримую пользу в сегменте бюджетного строительства.

\section{Литература}

1. Ватин, Н. И. Термопрофиль в легких стальных строительных конструкциях / Н. И. Ватин, Е. Н. Попова //. - Санкт-Петербург: Санкт-Петербург. гос. политехн. ун-т.,2006. - 63 c.

2. Wei-Wen Yu La Boube Cold-Formed Steel Design. / Wei-Wen Yu, Roger A. // 4th Edition изд. - Hoboken, New Jersey: John Wiley \& Sons, Inc., 2010. - 528 p.

3. Решетников А.А. Сравнительный анализ методик расчета тонкостенных стальных балок С-образного профиля по отечественным и зарубежным нормам/ А.А. Решетников, В.Ю.Корнет, Д.А. Леонова // Инженерный вестник Дона, 2018, №1.

4. Воронин А. В. Опыт стран Евросоюза в области технического нормирования тепловой защиты зданий и сооружений // Технологии строительства, 2007. № 4. - С. 24-26.

5. Jean-Baptiste Rieunier. «Low energy houses in Europe multi-comfort house concept»: Сб. докл. Международной научно-практической конференции «Эффективные тепло- и звукоизоляционные материалы в современном строительстве и ЖКХ»// М.: МГСУ, 2006. C.22-35.

6. Сравнительный анализ технологий строительства [Електронний ресурс] / Н. И.Ватин, А. С. Синельников, А. В. Малышева, Д. В. Немова - Режим доступу до ресурсу: https://imeks1stk.ru/services/privatePerson/stati/compare_technology.

7. К.В. Голубев, К.А. Федотов Проблемы использования новых технологий малоэтажного домостроения / К.В. Голубев, К.А. Федотов //Вестник ПНИПУ. Урбанистика, 2013. № 3 - C.23-30. 


\title{
References
}

[1]. Vatin, N. I. Termoprofil' v legkih stal'nyh stroitel'nyh konstrukciyah / N. I. Vatin, E. N. Popova //. - Sankt-Peterburg: Sankt-Peterburg. gos. politekhn. un-t.,2006. -63 p.

[2]. Wei-Wen Yu La Boube Cold-Formed Steel Design. / Wei-Wen Yu, Roger A. //- 4th Edition изд. - Hoboken, New Jersey: John Wiley \& Sons, Inc., 2010. - 528 p.

[3] Reshetnikov A.A. Sravnitel'nyj analiz metodik rascheta tonkostennyh stal'nyh balok Sobraznogo profilya po otechestvennym i zarubezhnym normam/ A.A. Reshetnikov, V.YU.Kornet, D.A. Leonova // Inzhenernyj vestnik Dona, 2018, №1.

[4] Voronin A. V. Opyt stran Evrosoyuza v oblasti tekhnicheskogo normirovaniya teplovoj zashchity zdanij i sooruzhenij // Tekhnologii stroitel'stva, 2007. № 4. - P. 24-26.

[5] Jean-Baptiste Rieunier. «Low energy houses in Europe multi-comfort house concept»: Sb. dokl. Mezhdunarodnoj nauchno-prakticheskoj konferencii «Effektivnye teplo- i zvukoizolyacionnye materialy v sovremennom stroitel'stve i ZHKKH»// M.: MGSU, 2006. P.22-35.

[6] Sravnitel'nyj analiz tekhnologij stroitel'stva [Elektronnyj resurs]. - Rezhim dostupa: https://imeks-lstk.ru/services/privatePerson/stati/compare_technology

[7] K.V. Golubev, K.A. Fedotov Problemy ispol'zovaniya novyh tekhnologij maloetazhnogo domostroeniya / K.V. Golubev, K.A. Fedotov //Vestnik PNIPU. Urbanistika, 2013. № 3 S.23-30.

\section{FACTORAL ASSESSMENT OF ENERGY-EFFECTIVE CONSTRUCTIVE- TECHNOLOGICAL SOLUTION OF THE THERMOPROFILE FROM THE LSTK}

\author{
Dmitrieva N.V., PhD, Assistant Professor, \\ Odesa State Academy of Civil Engineering and Architecture \\ dmitrieva.nv76@gmail.com ORCID ID: 0000-0002-4828-1644 \\ Agafonova I.P., Senior Lecturer \\ Bendery Polytechnic Branch of the TSU named after. T.G. Shevchenko \\ barkaririna@bk.ru ORCID ID: 0000-0003-4330-2642
}

\begin{abstract}
The features and advantages of innovative structural and technological solutions in construction based on lightweight metal structures are discussed there in the article. The problems of energy- and resource-saving in Ukraine are revealed.

Investigations of the main energy problems of Ukrainian cities are presented through the example of Odessa. The spacial layout and structural features of the cottage estate project in Leski village are also described here. The necessity of applying the methodology of factor evaluation in the optimization of structural and technological solutions of cottage building frame assembly is substantiated taking into consideration the energy efficiency. There are also presented the results of optimization of structural and technological solutions. Theку are specified two main factors affecting the choice of architectural, structural and technological solutions for the frame assembly: quantitative and qualitative. Qualitative criteria include: the possibility of year-round installation; ecological compatibility; fire safety.

Quantitative criteria include: cost of construction; minimum wall thickness (excluding insulation); frost resistance; sound insulation; duration of construction; operational life; coefficient of thermal conductivity.

In the process of selecting alternatives and determining criteria, the communicative individual method is used - when decision options are generated by a single expert.

Based on the data of factors evaluation, on a 5-point scale, the Light steel thin-walled structures technology scored the highest number of points - 67 points, the smallest - silicate brick -
\end{abstract}


37 points; it is evidence that solution of the Light steel thin-walled structures shows the best performance.

There are proposed some ways for solving the downsides of the Light steel thin-walled structures, such as the formation of thermal bridges, which can be reduced in two ways: by using of double frames or external heat insulation systems; ensuring the building tightness in relation to the wind, to the air and to the steam migration through the structure by the obligatory installation of wind protection and a vapor barrier; increasing the fire resistance limit of the Light steel thin-walled structures is provided in one of the ways: spraying and painting with various fire-resistant materials; plasterboard cladding; plastering.

Keywords: metal structures, the Light steel thin-walled structures, energy efficiency, factor evaluation, modular construction.

\title{
ФАКТОРНА ОЦНКА ЕНЕРГОЕФЕКТИВНОГО КОНСТРУКТИВНО- ТЕХНОЛОГІЧНОГО РІШЕННЯ 3 ТЕРМОПРОФІЛЮ ЛСТК
}

\author{
Дмитрієва Н.В., к.т. н., доцент, \\ Одеська державна академія будівниитва і архітектури \\ dmitrieva.nv76@gmail.com, ORCID ID: 0000-0002-4828-1644 \\ Агафонова І.П., старший викладач \\ Бендерського філії ПГУ ім. Т.Г.Шевченка \\ barkaririna@bk.ru,ORCID ID: 0000-0003-4330-2642
}

Анотація. У статті розглянуті особливості та переваги інноваційних конструктивнотехнологічних рішень в будівництві 3 використанням легких металевих конструкцій. Розкриваються проблеми енерго- та ресурсозбереження в Україні.

Наведені дослідження основних енергетичних проблем міст України, на прикладі м. Одеса. Охарактеризовані об'ємно-планувальні та конструктивні особливості проекту котеджного селища в с. Ліски Одеської області. Обгрунтовано необхідність застосування методики факторної оцінки при оптимізації конструктивно-технологічних рішень зведення каркаса котеджних будівель з урахуванням енергоефективності. Представлені результати оптимізації конструктивно-технологічних рішень. У дослідженні були виділені основні фактори, що впливають на вибір архітектурних і конструктивно-технологічних рішень зведення каркаса: кількісні та якісні. До якісних критеріїв відносяться: можливість всесезонного монтажу; екологічність; пожежна безпека.

До кількісних критеріїв належать: вартість будівництва; мінімальна товщина стіни (без урахування утеплювача); морозостійкість; шумоізоляція; тривалість будівництва; довговічність; коефіцієнт теплопровідності.

При відборі альтернатив i визначення оцінки критеріїв використовувався комунікативний індивідуальний метод - коли варіанти рішень генерує єдиний експерт.

На підставі даних оцінки факторів, за 5-ти бальною шкалою, найбільшу кількість балів набрала технологія ЛСТК - 67 балів, найменше - силікатна цегла - 37 балів, це свідчить про те, що найкращі показники показує рішення з ЛСТК.

Запропоновано способи вирішення недоліків ЛСТК, таких як утворення теплових мостів можливо зменшити двома способами: використання подвійних каркасів або використання зовнішніх систем утеплення; забезпечення герметичності будівлі по відношенню до вітру, до повітря і до міграції пара через конструкцію обов'язковим монтажем вітрозахисту і паронепроникного бар'єру; підвищення межі вогнестійкості ЛСТК, забезпечується одним із способів: напилення i забарвлення різними вогнетривкими матеріалами; облицювання гіпсокартоном; оштукатурювання.

Ключові слова: металеві конструкції, ЛСТК, енергоефективність, факторна оцінка, модульне будівництво. 


\title{
СТІЙКІСТЬ МЕТАЛЕВИХ ОДНОПОЯСНИХ СІТЧАСТИХ КУПОЛІВ 3 ПОЧАТКОВИМИ НЕДОСКОНАЛОСТЯМИ
}

\author{
Коломійчук Г.П., к.т.н., доцент, \\ Одеська державна академія будівництва та архітектури \\ gp11k1m@gmail.com, ORCID: 0000-0003-4484-7791
}

\begin{abstract}
Анотація. Розглянуто стійкість металевих однопоясних сітчастих куполів 3 початковими недосконалостями форми що отримані під час будівництва конструкції. В дослідженні зроблено заміну сітчастого купола на суцільний i проаналізовано його неосесиметричне деформування 3 втратою стійкості від біфуркаційних навантажень. Показано що найбільший вплив на втрату стійкості мають недосконалості форми серединної поверхні куполу. Наведені підходи що зближують невідповідність між результатами експериментальних критичних навантажень втрати стійкості та теоретичними. Отримана залежність що дозволяє корегувати критичне навантаження куполу з урахуванням амплітуди виміряних недосконалостей побудованої конструкції.
\end{abstract}

Ключові слова: сітчастий купол, стійкість, початкові недосконалості, критичне навантаження, біфуркація.

Вступ. Купол - найбільш раціональне покриття в будівлях та спорудах круглої форми. Найчастіше в практиці будівництва застосовуються пологі металеві сіткові куполи. Такі конструкції дозволяють утворювати менший будівельний об'єм, але їх робота під дією навантаження значно ускладнюється. I на сьогодні не достатньо вирішені проблеми розрахунку стійкості таких куполів. Основною причиною $є$ розбіжність між експериментальними даними та виконаними розрахунками. Дійсна форма та положення вузлів сіткового куполу, а також його реальний напружено-деформований стан в процесі експлуатації відрізняється від стану розробленого проектом. Накопичені відхилення геометрії куполу під час його монтажу, дефекти при виготовленні та пошкодження отримані під час експлуатації значно змінюють ідеальну розрахункову схему, що використана в розрахунках, і збільшують ймовірність втрати стійкості.

Аналіз останніх досліджень та публікацій. Каркаси великопрольотних металевих куполів включають в себе безліч конструкцій, які перед монтажем збираються з окремих відправних марок у вигляді секцій або елементів. При цьому незначні відмінності окремих монтажних конструкцій однієї від іншої в межах допусків відображаються похибками просторового положення їх вузлів, тобто геометрична форма споруди спотворюється. В результаті цього дійсний стан вузлів просторової споруди отримує певні відхиленнями в порівнянні з проектом [1].

В роботі А.М. Югова і А.Б. Бондарева [2] досліджені величини відхилень і монтажний напружено-деформований стан (МНДС) однопояснї стержневої металевої циліндричної оболонки покриття. В результаті проведених досліджень розроблена комп'ютерна програма $\mathrm{i}$ методика для розрахунку точності шарнірно-стержневих великопрольотних просторових металевих покриттів, і методика визначення МНДС.

Комп'ютерний аналіз величин початкових зусиль при силовому усуненні похибок монтажу двохпоясного ребристо-кільцевого металевого куполу виконано в роботі [3]. Розглянуто похибки положення вузлів парних меридіональних ребер в нормальному i меридіональному напрямках при монтажі купольного каркасу з тимчасовою центральною опорою. До обраних вузлів прикладалися зосереджені сили, для ліквідації відносних відхилень суміжних ребер, і фіксувалися виникаючі в стержнях початкові зусилля.

Отримані залежності в [4], що описують характер поведінки стержневих багатогранників, з яких збираються одношарові сітчасті куполи, дозволяють враховувати їх геометрично нелінійне деформування, поздовжньо-поперечний вигин в стержнях і початкові 
геометричні недосконалості форми осесимметричного характеру, що дає можливість найбільш точно обчислити величину критичного навантаження.

Однак велика кількість досліджень суцільної сферичної оболонки, а також огляд наведених літературних джерел не дає відповіді на отримання величини критичного навантаження сітчастого куполу з урахуванням довільних початкових недосконалостей.

Мета та завдання. Метою даного дослідження є з'ясування ступеня впливу довільних обмежених початкових недосконалостей форми побудованого сітчастого куполу на його критичне навантаження.

На відміну від подібних досліджень інших авторів, де форма початкової недосконалості куполу задавалася теоретично на розсуд дослідника досить довільним чином, в даній роботі в якості початкових недосконалостей використані форми вигнутої поверхні сферичної оболонки взяті з експериментальних випробувань для отримання залежності критичного навантаження втрати стійкості від амплітуди недосконалості.

Завдання дослідження:

- виконати аналіз неосесиметричного деформування суцільних сферичних куполів 3 втратою стійкості від біфуркаційних навантажень;

- класифікувати початкові недосконалості отримані під час виготовлення та їх врахування в розрахункових моделях;

-виявити підходи що зближують невідповідність між отриманим експериментально критичним навантаженням та теоретичним;

-отримати залежність що враховує вплив початкових недосконалостей на критичне навантаження втрати стійкості.

Матеріали та методика дослідження. Особливістю одношарових сітчастих куполів $\epsilon$ схильність до явного геометрично нелінійного деформування при дії зовнішнього навантаження. Один 3 видів втрати стійкості форми, що супроводжується геометрично нелінійним процесом деформування, проявляється в продавлюванні до центру кривизни описаної сфери окремих вузлів. Це явище пов'язане з деяким скороченням стержнів, в результаті чого зовнішнє навантаження не може бути сприйняте зі збереженням випуклої форми окремих стержневих багатогранників, що утворюють сітчастий купол.

Існуючі методики перевірки стійкості форми одношарових сітчастих куполів найбільш часто засновані на аналітичних і чисельних методах розрахунку. Відсутність критеріїв настання втрати стійкості форми одношарових сітчастих куполів в використовуваних кінцево-елементних програмних комплексах ускладнює їх використання.

Дослідження одношарових сітчастих куполів дозволило встановити, що найбільш істотний вплив на величину критичного вузлового навантаження, що викликає продавлювання до центру кривизни описаної поверхні вузлів одношарових сітчастих куполів, мають початкові геометричні недосконалості форми.

В силу малої кількості експериментальних досліджень перевірки стійкості форми одношарових сітчастих куполів не вдається зробити верифікацію отриманих методик, тому для порівняння в роботі використовуються континуальні моделі.

В результаті аналізу існуючих підходів по отриманню критичного навантаження втрати стійкості форми одношарових сітчастих куполів віддано перевагу методиці, що враховує довільні початкові недосконалості форми, виміряні на стенді перед початком прикладення навантаження.

Результати досліджень. Сітчасті куполи розраховують на міцність в фізично лінійній постановці з подальшою перевіркою стійкості конструкції. Один з основних підходів до розрахунку сіткового куполу заключається в заміні його суцільним вісесиметричним куполом. Виконуючи розрахунок по безмоментній теорії здійснюють зворотній перехід до дискретної схеми. При цьому визначають жорсткісні параметри еквівалентної суцільної оболонки, що має ту ж міцність на стиск, згин та кручення, як і задана сітчаста оболонка. Переміщення точок суцільної оболонки співпадають 3 переміщеннями вузлів сітчастої 
оболонки. Перехід від отриманих напружень в суцільній оболонці до зусиль в стержневій сітчастій системі базується на умовах статичної рівноваги.

В подальшому дослідженні перейдемо до розгляду суцільного сферичного куполу.

Теорія тонкостінних оболонок $є$ одним 3 найбільш детально вивчених розділів механіки. Однак, незважаючи на іiі рівень опрацювання, в даний час ще залишаються невирішені проблеми. Однією 3 них є проблема, яка полягає в відсутності достатнього обгрунтування причин розбіжності теоретично і експериментально знайдених критичних навантажень втрати стійкості для тонкостінних оболонок.

До найбільш досліджених оболонок можна віднести сферичний купол. Масова кількість дослідів та теоретичних розрахунків припадає на пружні сферичні оболонки жорстко закріплені по контуру, навантажені рівномірним поперечним тиском. Майже всі автори теоретичних досліджень для опису втрати стійкості куполу з урахуванням його геометрично нелінійного попереднього напружено-деформованого стану використовували рівняння Маргерра.

Зіставлення експериментально і теоретично отриманих значень критичних навантажень для жорстко закріплених по контуру пологих сферичних куполів, які перебувають під дією рівномірного поперечного тиску, показує їх значне розходження. Це видно на рис. 1, взятому $3[5]$.

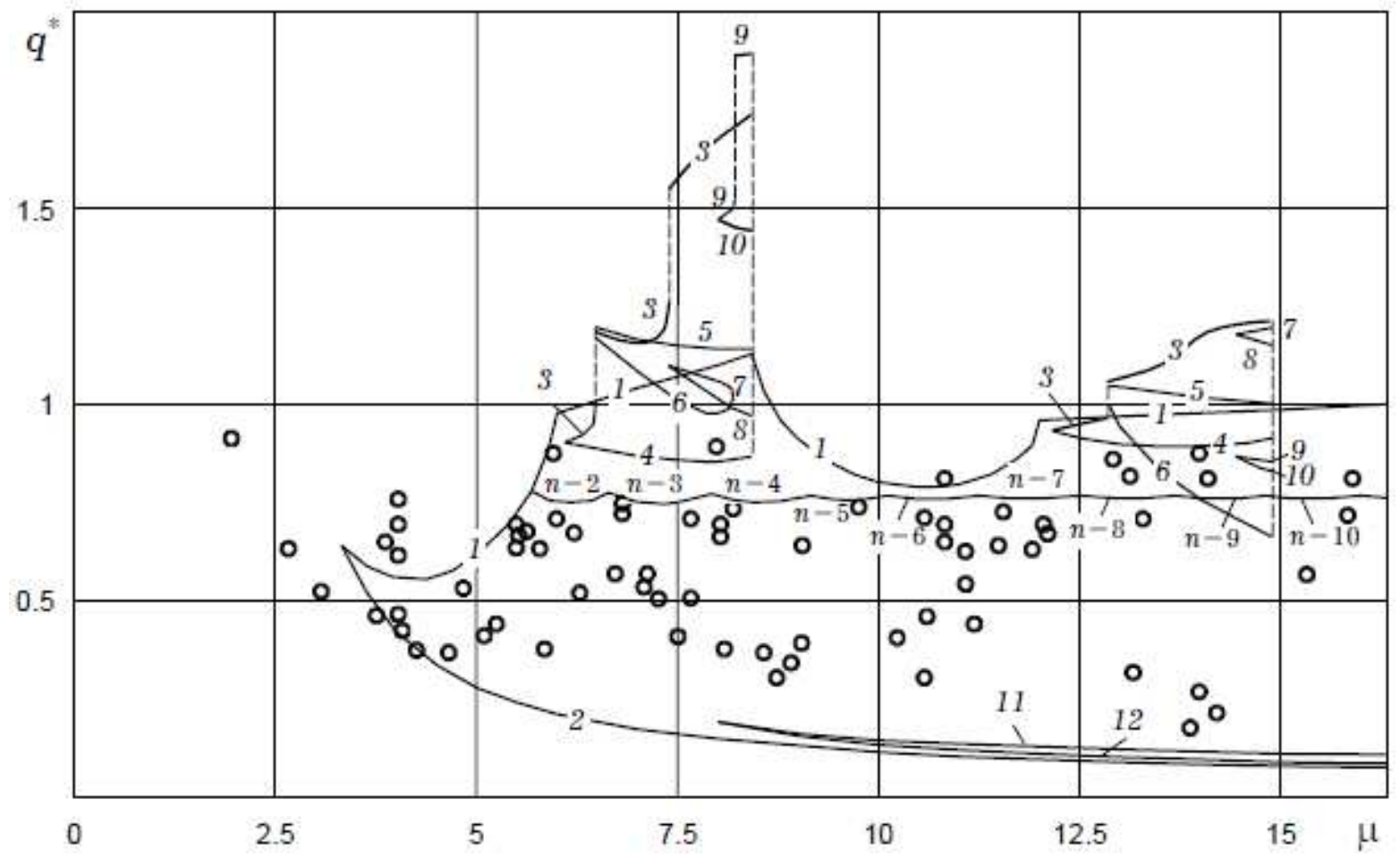

Рис.1. Залежність критичних навантажень втрати стійкості від параметру тонкостінності

На рис. 1 під $q^{*}$ розуміється безрозмірний поперечний тиск, а під $\mu$ - параметр тонкостінності оболонки. Суцільними лініями на рис. 1, що зазначені цифрами 1 і 2, показані теоретично знайдені залежності верхнього $q^{*^{+}}$i нижнього $q^{*^{-}}$критичних навантажень ідеального сферичного куполу, що осесиметрично деформується, від його параметру тонкостінності. Ці залежності отримані різними авторами за допомогою вирішення рівнянь К. Маргерра і Е. Рейсснера. Кружочками на рис. 1 відзначені значення верхнього критичного навантаження, які взяті з експериментальних робіт різних дослідників.

До цих пір не існує набору параметрів математичної моделі оболонки, записаної на основі рівнянь Маргерра або Рейсснера, за допомогою незначного варіювання яких можна було б отримати весь спектр експериментально знайдених значень верхнього критичного навантаження. У такій ситуації для інженерних розрахунків застосовується корекція теоретично отриманих значень критичного навантаження за допомогою трьох 
експериментально знайдених коефіцієнтів, що враховують початкові прогини оболонки, вид граничних умов і можливість роботи матеріалу оболонки в пружно-пластичній області.

Ще в 1963 році Хуану вдалося отримати достовірні значення неосесиметричних критичних навантажень для ідеального, жорстко закріпленого по контуру пологого сферичного куполу [6]. Знайдені ним критичні навантаження відповідають точкам біфуркації на траєкторії навантаження оболонки що осесиметрично деформується. У них купол, перебуваючи в умовах осесиметричного геометрично нелінійного, моментного напруженодеформованого стану, викликаного рівномірним поперечним тиском, отримує можливість деформуватися відповідно з однією, двома, трьома і т.д. хвилями по колу. Значення цих навантажень дещо менше верхнього критичного навантаження. Крива, що показує залежність величини найменшого неосесиметричного критичного навантаження від параметру тонкостінності, відзначена на рис. 1 значеннями $\mathrm{n}=2,3, \ldots, 10$, де $\mathrm{n}$ позначає кількість хвиль по колу купола, відповідно цьому навантаженню.

В [5] вперше показано, що оболонки мають закритичні неосесиметричні стани рівноваги 3 навантаженнями, значно меншими за верхнє критичне навантаження, так i навантаженнями, що відповідають точкам біфуркації. Зроблено припущення про те що врахування форм закритичних неосесиметричних станів рівноваги в якості початкових недосконалостей сферичного куполу повинно змоделювати розкид його експериментально знайденого критичного навантаження.

Закритична поведінка оболонки полягає у визначенні іiі рівноважних станів в умовах, при яких оболонка вже втратила свою несучу здатність. Ці стани рівноваги є нестійкими і в умовах експлуатації конструкції реалізовані бути не можуть. Однак знання повної картини поведінки оболонки дозволяє по-іншому поглянути на процес іï деформування і зрозуміти ті його явища, які з позицій в тій чи іншій мірі ідеалізованих математичних моделей оболонки залишаються непоясненими.

Фрагмент картини деформування пологого ідеального сферичного куполу показано на рис. 2. Крім граничної точки В, критичного навантаження осесиметричної втрати стійкості, на траєкторії навантаження куполу присутні точки біфуркації $\left(\mathrm{H}_{1}, \mathrm{H}_{2}, \mathrm{H}_{3}, \mathrm{H}_{4}, \mathrm{~K}_{1}, \mathrm{~K}_{2}, \mathrm{~K}_{3}, \mathrm{~K}_{4}\right)$. Це говорить про те, що при дії осесиметричного навантаження купол може деформуватися неосесиметрично. В точках біфуркації $\left(\mathrm{H}_{1}, \mathrm{H}_{2}, \mathrm{H}_{3}, \mathrm{H}_{4}\right)$ виникає Ейлерова втрата стійкості купола з утворенням відповідно однієї, двох, трьох і чотирьох хвиль по кругу.

Реальна конструкція сферичного куполу обов'язково має малі відхилення від ідеальної сферичної форми. Тому при навантаженні рівномірним поперечним тиском купол з самого початку буде деформуватися неосесиметрично в відповідності з тим, яка складова початкової недосконалості в нього домінує.

Початкові дефекти тонкостінних оболонок можуть бути класифіковані в такий спосіб: - недосконалості форми - початкові прогини або вм'ятини, відхилення фактичних розмірів від заданих; - недосконалості напруженого стану - наявність полів самоурівноважених початкових напружень, полів макровластивостей матеріалу і т. п.; - недосконалості впливів відхилення реальних умов завантаження від розрахункових, пульсація навантаження; недосконалість граничних умов. Найбільш небезпечними, як правило, виявляються недосконалості форми.

Велика кількість теоретичних і експериментальних досліджень як вітчизняних, так і зарубіжних авторів присвячена оцінці впливу початкових прогинів на стійкість оболонок. Більшість їх виконані стосовно пружних, переважно металевих оболонок.

Дослідження впливу початкових прогинів тонкостінних оболонок можна розподілити на чотири групи: - довільні початкові прогини - зазвичай це роботи присвячені чисельним рішенням на ЕОМ відповідних рівнянь; - початкові прогини що копіюють форму втрати стійкості оболонки ідеальної форми - дослідження початкового післякритичного стану і чутливості до початкових прогинів; - початкові прогини локальних видів - вм'ятини, плоскі ділянки і т.д.; - випадкові початкові прогини [7]. 


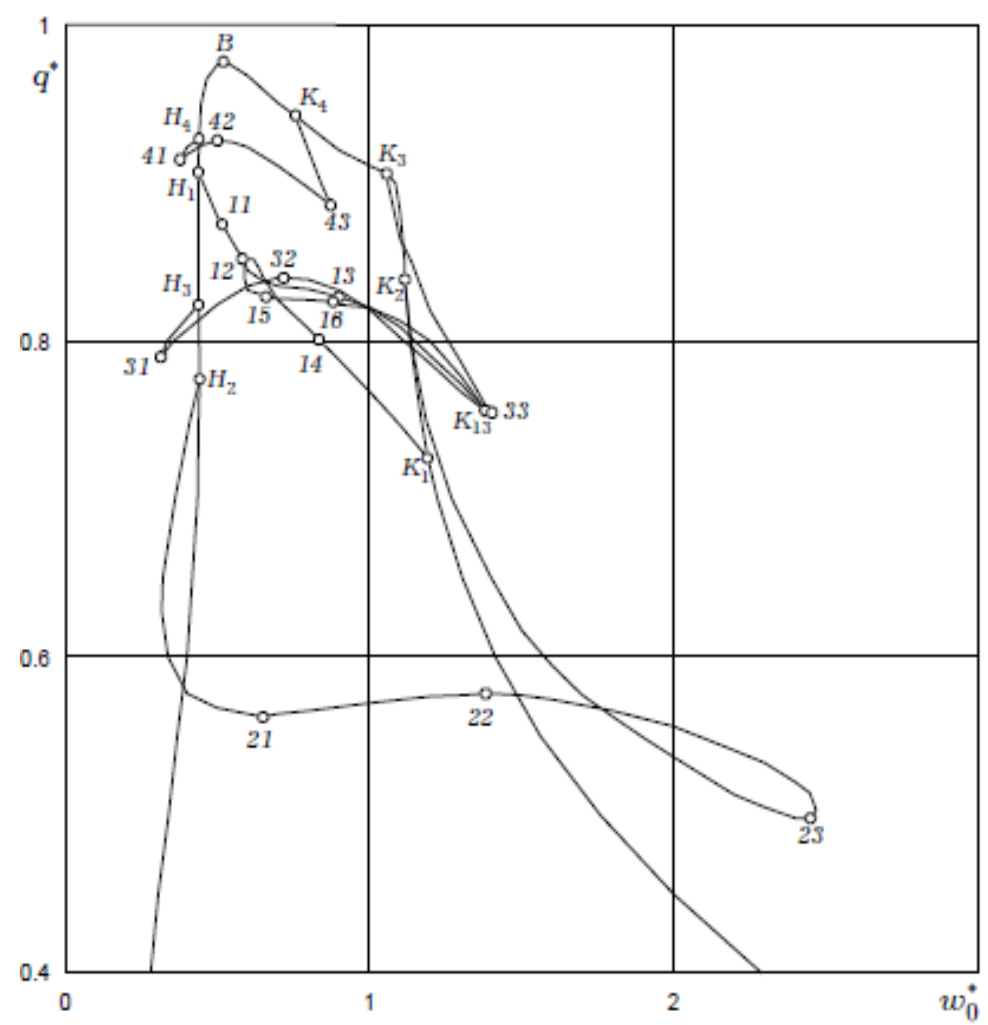

Рис. 2. Траєкторія поведінки сферичної оболонки під рівномірним поперечним тиском 3 параметром тонкостінності $\mu=6$

З'ясування ступеня впливу осесиметричних початкових недосконалостей форми сферичної оболонки на їі критичне навантаження показано на рис. 3 [8]. На відміну від подібних досліджень інших авторів, де форма початкової неправильності оболонки задавалася на розсуд дослідника досить довільним чином, в даній роботі в якості початкових недосконалостей використані форми вигнутої поверхні ідеальної сферичної оболонки, властиві їй на етапах до- і закритичного деформування.

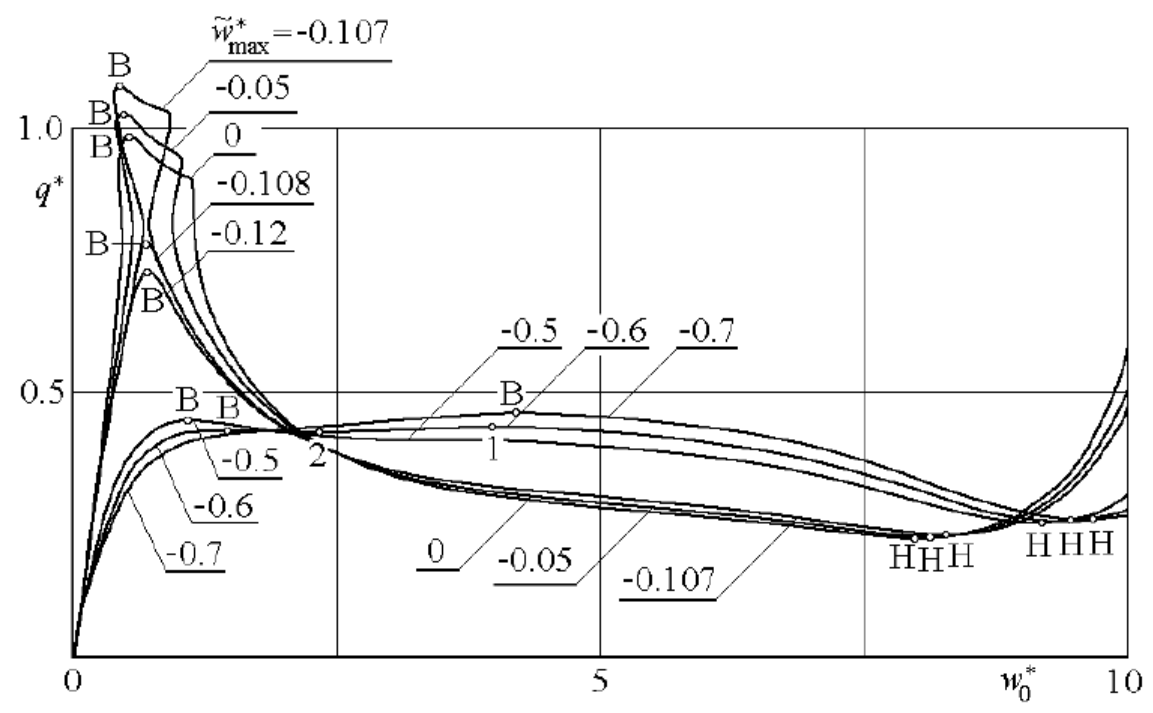

Рис. 3. Вплив осесиметричних недосконалостей форми купола на критичне навантаження 
Для кожного знайденого виду початкової осесиметричної неправильності куполу в розглянутому діапазоні значень його найбільшого відносного відхилення були побудовані траєкторії навантаження (рис. 3).

Прийнятний компроміс між розрахунковими і експериментальними результатами було досягнуто С. Ямадою, К. Учіямою і М. Ямадою, які спочатку намагалися знайти їх узгодженості за допомогою введення обраних за власним розсудом осесиметричних i неосесиметричних початкових недосконалостей форми сферичної оболонки [9, 10]. Суть цього підходу полягає в наступному. При виконанні експериментів, крім прогинів оболонки і відповідних їм навантажень, автори заміряли початковий прогин кожної ненавантаженої

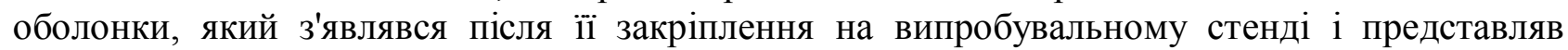
собою випадкову неосесиметричну функцію. Ці дані про початковий прогин оболонки, який апроксимувався кінцевими сумами у вигляді поліномів по радіусу i косинусами - по окружній координаті оболонки, використовувалися в розрахунках процесу спочатку неосесиметричного деформування оболонки 3 iï проклацуваням і подальшим повним вивертанням. В результаті була отримана висока ступінь узгодженості теоретичних $\mathrm{i}$ експериментальних значень верхнього критичного навантаження.

Дослідження С. Ямади, К. Учіями і М. Ямади підтвердили правомірність використання рівнянь Маргерра для опису процесу деформування пологих оболонок в умовах звичайно прогинів, їх проклацування і закритичної поведінки. Вони підтвердили припущення про високу чутливість пологого сферичного купола до початкових недосконалостей, але не вказали на причини такої чутливості. А вона, як видно, полягає в тому, що сферичні оболонки володіють вибірковою чутливістю до початкових недосконалостей. Оболонка більшою мірою реагує на вид початкової неправильності, а не на ії величину.

Виходячи з складнощів досліджень стійкості, для побудови залежності між критичним навантаженням втрати стійкості та амплітудою початкових недосконалостей і використання iii в інженерних розрахунках сітчастих куполів, було обрано такий підхід. На геометрію виготовленого сферичного куполу вводяться обмеження на амплітуду початкових недосконалостей. В якості таких обмежень можуть бути використані допуски відхилень геометрії на виконання будівельно-монтажних робіт.

Для отримання залежності між критичним навантаженням втрати стійкості та амплітудою початкових недосконалостей використані відомі результати експериментальних досліджень наведених вище авторів, а також ті де була висока точність в вимірах недосконалостей та в проведені навантаження сферичних оболонок [11]. Критичне навантаження розглядалося в відношенні до класичного $q^{*}=q / q_{\text {кл }}$, а амплітуда початкових недосконалостей в відношенні до товщини оболонки $w_{0}^{*}=w_{0} / h$. Було обрано для побудови залежності таку кількість дослідних моделей $3 w_{0} / h: 0,0 \ldots 0,2-12 ; 0,2 \ldots 0,4-16 ; 0,4 \ldots$ $0,6-14 ; 0,6 \ldots 0,8-8 ; 0,8 \ldots 1,0-3$. Всього обрано 53 моделі. В результаті обробки даних отримано залежність (1).

$$
q^{*}=0,825-0,209\left(w_{0}^{*}\right)+3,102\left(w_{0}^{*}\right)^{2}-1,525\left(w_{0}^{*}\right)^{3}
$$

Залежність дозволяє вводити поправки на величину критичного навантаження втрати стійкості сітчастих куполів, де в якості вихідних даних будуть використані; - приведена товщина куполу; - найбільша амплітуда виміряних початкових недосконалостей форми після зведення конструкції на будівельному майданчику.

Висновки. Для досягнення мети дослідження зроблено заміну сітчастого купола на суцільного і проаналізовано його неосесиметричне деформування 3 втратою стійкості від біфуркаційних навантажень. Виконано класифікацію початкових дефектів та показано, що найбільший вплив на втрату стійкості мають недосконалості форми серединної поверхні куполу. Наведені підходи що зближують невідповідність між отриманим експериментально критичним навантаженням втрати стійкості та теоретичним. Для інженерних розрахунків втрати стійкості сітчастих куполів отримана залежність що дозволяє корегувати критичне 
навантаження 3 урахуванням амплітуди виміряних недосконалостей побудованої конструкції.

Для подальших досліджень важливо дослідити вплив штучно створених початкових відхилень вузлів сітчастого куполу від ідеальної сферичної форми в напрямку протилежному втраті стійкості за рахунок чого може бути досягнуто значне збільшення критичного навантаження.

\section{Література}

1. Мосягин Д.Л. Фактические несовершенства формы поверхности купольных покрытий резервуаров объемом $50000 \mathrm{~m}^{3}$ / Д.Л. Мосягин, В.А. Голованов, Е.Г. Ильин // Промышленное и гражданское строительство, 2011. - № 6. - С. 30-32.

2. Югов А.М. Напряженно-деформированное состояние однопоясной стержневой металлической оболочки покрытия цилиндрической формы при наличии погрешностей изготовления и монтажа / А.М. Югов, А.Б. Бондарев // Металлические конструкции, 2013. T. 19. - №1. - С. 27-36.

3. Григорян А.А. Величины начальных усилий в двухпоясном металлическом куполе при устранении нормальных и меридиональных погрешностей монтажа / А.А. Григорян, Е.В. Лебедь // Вестник МГСУ, 2016. - № 1. - С. 44-56.

4. Глушко К.К. Устойчивость формы стальных однослойных сетчатых куполов с жесткими узлами при действии распределенной внешней нагрузки / К.К. Глушко // Вестник Брестского ГТУ, 2019. - №1. - С. 71-76.

5. Григолюк Э.И. Устойчивость и закритическое поведение пологой сферической оболочки / Э.И. Григолюк, Е.А. Лопаницын // Математичні методи та фізико-хімічні поля, 2003. - Вип. 46. - №1. - С. 75-87.

6. Григолюк Э.И. Механика деформирования сферических оболочек / Э.И. Григолюк, В.И. // Мамай. - М., Изд-во МГУ, 1983. - 114 с.

7. Коломийчук Г.П. Влияние начальных несовершенств формы на устойчивость металлических и пластмассовых моделей замкнутых цилиндрических оболочек при осевом сжатии / Г.П. Коломийчук // Мат-лы V межд. симп. «Современные конструкции из металла и древесины». - Одесса, ВМК «Місто майстрів», 2001. - С. 130-132.

8. Григолюк Э.И. Влияние осесимметричных начальных неправильностей сферической оболочки на ее критическую нагрузку / Э.И. Григолюк, Е.А. Лопаницын // Изв. МГТУ «МАМИ». - М., МГТУ «МАМИ», 2008. - №1. - С. 233-245.

9. Yamada S. Experimental investigation of the buckling of shallow spherical shells / S. Yamada, K. Uchiyama, M. Yamada // J. Non-Linear Mech, 1983. - V.18. - №1. - P. 37-54.

10. Yamada M. Agreement between theory and experiment on large-deflection behaviour of clamped shallow spherical shells under external pressure / M. Yamada, S. Yamada // Collapse. Ed. J.M.T. Tompson and J.W. Hant. - Cambrige Univ. Press, 1983. - P. 431-441.

11. Чуриков Б.В. Учет влияния начальных несовершенств на устойчивость штампованных сферических оболочек / Б.В. Чуриков, Ю.П. Шишалов // Строительная механика и расчет сооружений, 1978. - №6. - С. 28-31.

\section{References}

[1] Mosyagin D.L. Fakticheskiye nesovershenstva formy poverkhnosti kupol'nykh pokrytiy rezervuarov ob"yemom $50000 \mathrm{~m}^{3}$ / D.L. Mosyagin, V.A. Golovanov, Ye.G. Il'in // Promyshlennoye i grazhdanskoye stroitel'stvo, 2011. - №6. - S. 30-32.

[2] Yugov A.M. Napryazhenno-deformirovannoye sostoyaniye odnopoyasnoy sterzhnevoy metallicheskoy obolochki pokrytiya tsilindricheskoy formy pri nalichii pogreshnostey izgotovleniya i montazha / A.M. Yugov, A.B. Bondarev // Metallicheskiye konstruktsii, 2013. - T.19. - №1. - S. 27-36. 
[3] Grigoryan A.A. Velichiny nachal'nykh usiliy v dvukhpoyasnom metallicheskom kupole pri ustranenii normal'nykh i meridional'nykh pogreshnostey montazha / A.A. Grigoryan, Ye.V. Lebed' // Vestnik MGSU, 2016. - №1. - S. 44-56.

[4] Glushko K.K. Ustoychivost' formy stal'nykh odnosloynykh setchatykh kupolov s zhestkimi uzlami pri deystvii raspredelennoy vneshney nagruzki / K.K. Glushko // Vestnik Brestskogo GTU, 2019. - №1. - S. 71-76.

[5] Griholyuk E.I. Ustoychyvost' y zakrytycheskoe povedenye polohoy sferycheskoy obolochky / E.I. Griholyuk, E.A. Lopanytsyn // Matematychni metody ta fizyko-khimichni polya, 2003. - Vyp. 46. - №1. - S. 75-87.

[6] Grigolyuk E.I. Mekhanika deformirovaniya sfericheskikh obolochek / E.I. Grigolyuk, V.I. Mamay. - M., Izd-vo MGU, 1983. - 114 s.

[7] Kolomiychuk G.P. Vliyaniye nachal'nykh nesovershenstv formy na ustoychivost' metallicheskikh i plastmassovykh modeley zamknutykh tsilindricheskikh obolochek pri osevom szhatii / G.P. Kolomiychuk // Mat-ly V mezhd. simp. «Sovremennyye konstruktsii iz metalla i drevesiny». - Odessa, VMK «Místo maystrív», 2001. - S. 130-132.

[8] Grigolyuk E.I. Vliyaniye osesimmetrichnykh nachal'nykh nepravil'nostey sfericheskoy obolochki na yeye kriticheskuyu nagruzku / E.I. Grigolyuk, Ye.A. Lopanitsyn // Izv. MGTU «MAMI». - M., MGTU «MAMI», 2008. - №1. - S. 233-245.

[9] Yamada S. Experimental investigation of the buckling of shallow spherical shells / S. Yamada, K. Uchiyama, M. Yamada // J. Non-Linear Mech, 1983. - V.18. - №1 - - P. 37-54.

[10] Yamada M. Agreement between theory and experiment on large-deflection behaviour of clamped shallow spherical shells under external pressure / M. Yamada, S. Yamada // Collapse. Ed. J.M.T. Tompson and J.W. Hant. - Cambrige Univ. Press, 1983. - P. 431-441.

[11] Churikov B.V. Uchet vliyaniya nachal'nykh nesovershenstv na ustoychivost' shtampovannykh sfericheskikh obolochek / B.V. Churikov, YU.P. Shishalov // Stroitel'naya mekhanika i raschet sooruzheniy, 1978. - №6. - S. 28-31.

\section{УСТОЙЧИВОСТЬ МЕТАЛЛИЧЕСКИХ ОДНОПОЯСНЫХ СЕТЧАТЫХ КУПОЛОВ С НАЧАЛЬНЫМИ НЕСОВЕРШЕНСТВАМИ}

Коломийчук Г.П., к.Т.н., доцент Одесская государственная академия строительства и архитектуры gp11k1m@gmail.com, ORCID: 0000-0003-4484-7791

Аннотация. В последнее время в практике строительства большепролетных пространственных покрытий чаще других используются пологие сетчатые купола. Такие конструкции позволяют образовывать меньший строительный объем, но их работа под действием нагрузок значительно усложняется. И сейчас недостаточно решены проблемы расчета устойчивости таких куполов. Основная причина заключается в различии между экспериментальными результатами и выполненными расчетами. Действительная форма и положение узлов сетчатого купола, а также его реальное напряженно-деформированное состояние в процессе эксплуатации отличаются от состояния выполненного проектом. Накопленные отклонения геометрии поверхности купола в процессе монтажа, дефекты при изготовлении значительно меняют идеальную расчетную схему, что использовалась в расчетах, и увеличивают вероятность потери устойчивости.

Рассмотрено устойчивость пологих металлических однопоясных сетчатых куполов с начальными несовершенствами формы, полученными в процессе возведения конструкции.

Выполнено замену сетчатого купола на сплошной и проанализировано его неосесимметричное деформирование с потерей устойчивости от бифуркационных нагрузок.

Приведено классификацию начальных несовершенств полученных конструкцией в процессе строительно-монтажных работ и отклонений прикладываемых к конструкции 
нагрузок. Показано что наибольшее влияние на потерю устойчивости пологого сферического купола имеют несовершенства формы срединной поверхности.

Определены подходы, которые ведут к сближению несоответствия между результатами экспериментальных критических нагрузок потери устойчивости и теоретическими. Наиболее важно в расчете устойчивости учитывать начальные несовершенства формы и неосесимметричное деформирование сферического купола с учетом несовершенств.

Для инженерных расчетов потери устойчивости пологих сетчатых куполов получена зависимость, позволяющая корректировать критическую нагрузку с учетом амплитуды измеренных начальных несовершенств построенной конструкции.

С целью дальнейших исследований важно исследовать влияние искусственно созданных начальных отклонений узлов сетчатого купола от идеальной сферической формы в направлении противоположном потери устойчивости за счет чего может быть достигнуто значительное увеличение критической нагрузки.

Ключевые слова: сетчатый купол, устойчивость, начальные несовершенства, критическая нагрузка, бифуркация.

\title{
STABILITY OF METAL SINGLE BELT MESH DOMES WITH INITIAL IMPERFECTIONS
}

\author{
Kolomiychuk G.P., PhD., Assistant Professor, \\ Odessa State Academy of Civil Engineering and Architecture \\ gp11k1m@gmail.com, ORCID: 0000-0003-4484-7791
}

\begin{abstract}
Recently, in the practice of constructing large-span spatial coatings, shallow mesh domes have been used more often than others. Such designs make it possible to form a smaller building volume, but their work under the influence of loads is much more complicated. And now the problems of calculating the stability of such domes are not sufficiently solved. The main reason is the difference between the experimental results and the performed calculations. The actual shape and position of the nodes of the mesh dome, as well as its actual stress-strain state during exploitation, differ from the state performed by the project. Accumulated deviations of the surface geometry of the dome during installation, manufacturing defects significantly change the ideal design scheme, which was used in the calculations, and increase the probability of loss of stability.

The stability of shallow metal single-belt mesh domes with initial shape imperfections obtained in the process of erection of the structures is considered.

The mesh dome was replaced with a continuous one and its nonaxisymmetric deformation with loss of stability from bifurcation loads was analyzed.

The classification of the initial imperfections obtained by the structure during construction and mounting and the deviations of the loads applied to the structure is given. It is shown that the greatest influence on the loss of stability of a shallow spherical dome has imperfections in the shape of the middle surface.

The approaches that lead to the convergence of discrepancies between the results of experimental critical loads of stability loss and theoretical are determined. In calculating stability, it is most important to take account of the initial imperfections of the form and the nonaxisymmetric deformation of the spherical dome, taking into account imperfections.

For engineering calculations, the stability loss of shallow mesh domes is obtained by a dependence that allows you to adjust the critical load to take account the amplitude of the measured initial imperfections of the constructed structure.

For the purpose of further research, it is important to investigate the effect of artificially created initial deviations of the mesh dome nodes from the ideal spherical shape in the direction opposite to the loss of stability, due to which a significant increase in the critical load can be achieved.
\end{abstract}

Keywords: mesh dome, stability, initial imperfections, critical load, bifurcation. 


\title{
ОСОБЛИВОСТІ ПРОЕКТУВАННЯ КОНВЕСРНОЇ ГАЛЕРЕЇ ЗЕРНОВОГО ПЕРЕВАНТАЖУВАЛЬНОГО КОМПЛЕКСУ
}

\author{
Купченко Ю.В., к.т.н., доцент, \\ steelconpro@gmail.com, ORCID: 0000-0003-1480-6884 \\ Сінгаївський П.М., к.Т.н., доцент, \\ mdipk@ukr.net, ORCID: 0000-0003-1268-414X \\ Константінов П.В., к.Т.н. \\ Konstantinov31@mail.ru, ORCID: 0000-0002-8478-2980 \\ Одеська державна академія будівництва та архітектури
}

\begin{abstract}
Анотація. У статті автори досліджують питання призначення раціонального конструктивного вирішення конвеєрної галереї зернового перевантажувального комплексу морського торгівельного порту. 3 різноманітних можливих конструктивних вирішень пролітної будови прийнята конструкція за розрізною схемою 3 об'ємного просторового блоку з несучими фермами, перерізи стержнів яких запроектовані із замкнутих тонкостінних гнутозварних профілів. Плоскі двогілкові опори галереї 3 одноплощинною розкісною з'єднувальною решіткою запроектовані в двох варіантах - 3 гілками 3 прокатного двотавра і, альтернативно, із складеного тонкостінного двотавра 3 гофрованою синусоїдальною стінкою.
\end{abstract}

Ключові слова: конвеєрна галерея, навантаження, пролітна будова, ферма, верхній пояс, нижній пояс, решітка, переріз, опора.

Вступ. Одним з важливих завдань в області вдосконалення будівельних конструкцій, у тому числі сталевих, є зниження їх матеріаломісткості, що може бути досягнуте на основі подальшого вивчення дійсної роботи конструкцій, вдосконалення розрахункових схем, розвитку конструктивної форми, вживання високоміцних сталей, використання ефективних типів поперечних перерізів елементів. Норми проектування сталевих конструкцій [1] рекомендують «обирати оптимальні за техніко-економічними показниками конструктивні схеми споруд; застосовувати прогресивні конструкції...; передбачати технологічність i найменшу трудомісткість виготовлення конструкцій; застосовувати конструкції, що забезпечують технологічність і найменшу трудомісткість монтажу».

В якості несучих конструкцій пролітних будов конвеєрних галерей широко використовуються як балочні конструкції, так і оболонки [2]. Найбільшого поширення набули балочні конструкції, які характеризуються високим рівнем технологічності, ремонтопридатності і легкістю монтажу, що дозволяє знизити капітальні і експлуатаційні витрати. Ефективним шляхом зниження металоємності є використання в балочних фермах стержнів 3 перерізами з квадратних труб, що володіють рівностійкістю. Ці та інші проектні рішення дозволяють отримати раціональне конструктивне вирішення конвеєрної галереї.

Аналіз останніх досліджень і публікацій. Галерея - протяжна, порожниста будівельна конструкція, призначена для розміщення і укриття технологічних комунікацій (стрічкових конвеєрів). Найбільшого поширення набули галереї з металевими несучими конструкціями пролітних будов і опор. Питанням проектування і розрахунку конвеєрних галерей присвячені роботи О.В. Зеленського, А.С. Петрова, А.В. Перельмутера, Є.В. Горохова, А.М. Югова, С.В. Колісніченка, В.М. Кущенка, А.Д. Німа, В.В. Хвороста, І.В. Баклашова, В.Н Борисова та ін. Практичні рекомендації за розрахунком і конструюванням конвеєрних галерей приведені в [2-11].

Метою роботи $є$ визначення раціонального конструктивного вирішення конвеєрної галереї перевантажувального комплексу, що забезпечує надійність і несучу здатність проектованої конструкції. 
Результати досліджень. Конвеєрна галерея, що проектується, входить до складу зернового перевантажувального комплексу, розташованого на території морського торгівельного порту і призначеного для прийому, короткочасного зберігання і відпустки зернових культур. Транспортно-технологічні лінії комплексу розраховані на запланований річний об'єм перевалки зернових вантажів до 2,5 млн. тонн. Споруда конвеєрної галереї має довжину 118,69 $м$ (рис. 1, 2).

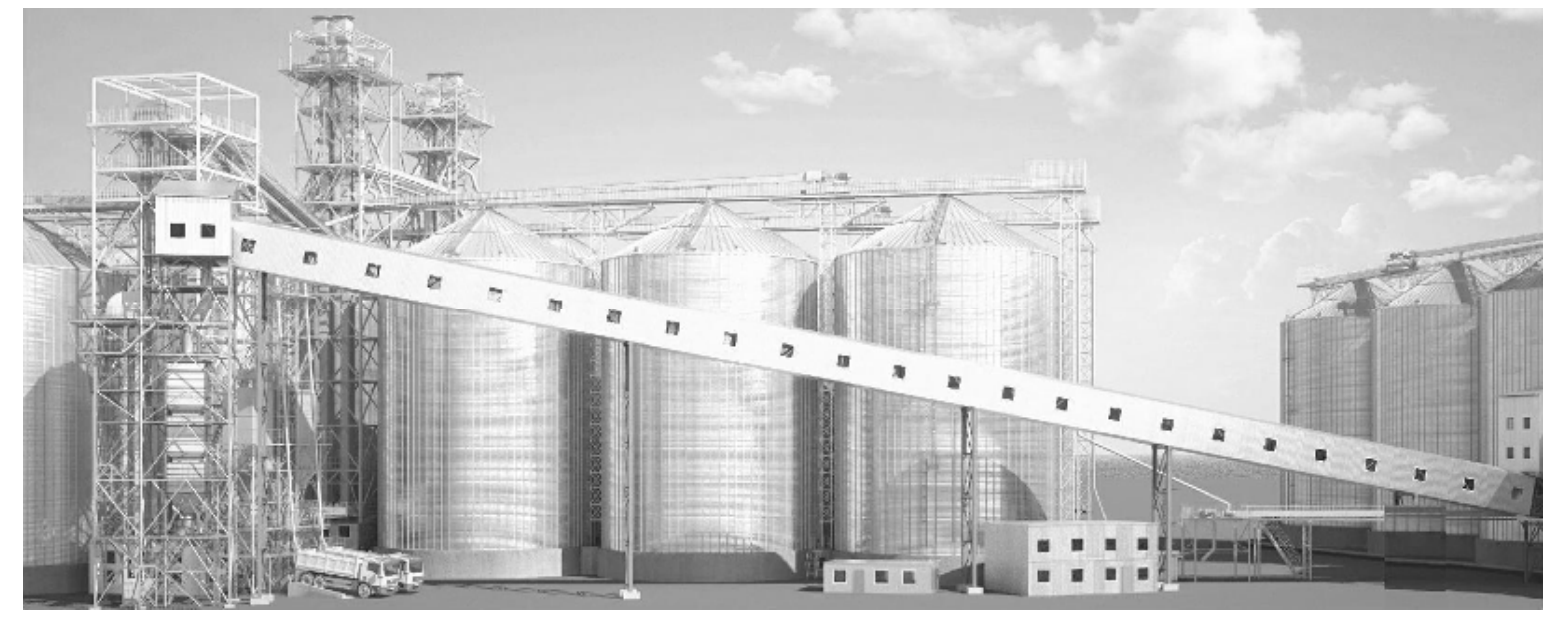

Рис. 1. Загальний вигляд конвеєрної галереї

Галерея прийнята 3 одного температурного блоку, оскільки найбільша довжина температурного блоку неопалювальних і опалювальних пролітних будов з розташуванням несучих конструкцій зовні, яка визначається як відстань від нерухомої опори до температурного шва, не повинна перевищувати 130 м [2].

Нерухомою опорою, що забезпечує стійкість конструкції в подовжньому напрямі, $є$ перевантажувальна станція, розташована по осі 1/11 (рис. 2).

Конвеєрна галерея, відповідно до генплану, складається з чотирьох пролітних будов (завдовжки $36,18,30,30$ м) і п'яти опор заввишки 5,86 $м, 12,39 \mu, 15,65 \mu, 21,16 \mu, 26,68$. Подовжній ухил галереї при цьому склав $12^{\circ}$, що менше ніж $24^{\circ}$ відповідно до умов нормальної експлуатації стрічкових конвеєрів.

За типом конструктивних рішень пролітні будови галереї можуть належати до однієї 3 трьох груп: несучі конструкції пролітних будов із сталевих ферм 3 паралельними поясами, 3 огороджувальними конструкціями панельного типу; несучі конструкції пролітних будов із зварних двотаврових балок, у тому числі - 3 гнучкими стінками, 3 огороджувальними конструкціями покриття і перекриття різного типу; несучі конструкції пролітних будов 3 металевих оболонок прямокутного або круглого перерізу, що поєднують функції несучих i огороджувальних. Для конструкції, що проектується, вибрана пролітна будова 3 ферм 3 паралельними поясами, як найбільш технологічна і така, що проста в монтажі.

Внутрішні розміри пролітної будови галереї по ширині і висоті повинні забезпечувати нормальні і безпечні умови експлуатації і ремонту конвеєрів. Ширина 3 врахуванням розташування одного стрічкового конвеєра і пристроєм проходів 3 двох сторін прийнята 3,3 $м$ (табл. 1 [2]). Висота пролітної будови з врахуванням [2] (не менше ніж 2,3 $м$ ) і вимог жорсткості конструкції склала 3,2 $м$ між осями поясів ферм.

Пролітні будови виконуються за розрізною схемою і складаються 3 двох плоских несучих ферм заввишки 3,2 $м$ з паралельними поясами і трикутною решіткою 3 додатковими стійками, сполучених між собою в об'ємний просторовий блок шириною 3,3 $м$ поперечними балками покриття і перекриття, горизонтальними зв'язками по нижніх і верхніх поясах ферм і опорними рамами по торцях, що мають жорстке з'єднання ригеля 3 опорними стійками несучих ферм.

Функцію жорсткої опори виконує перевантажувальна станція, всі інші опори проектуються плоскими, які допускають зсув в подовжньому напрямі при температурних 
переміщеннях. Проектовані плоскі опори складаються 3 двох вертикальних гілок і з'єднувальної розкісної решітки. Ширина опор прийнята 3,3 м у відповідності з розміром пролітної будови галереї.
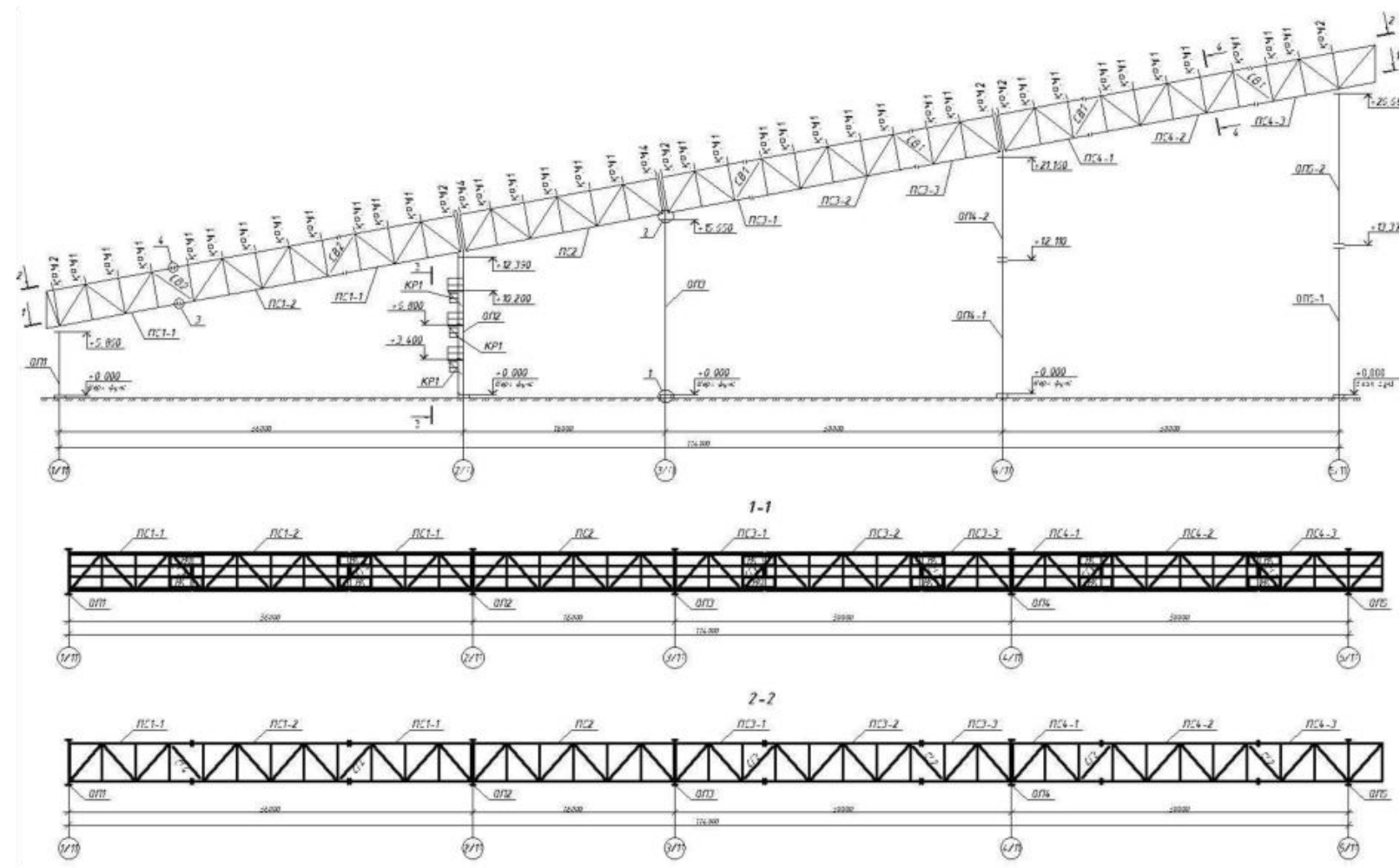

Рис. 2. Монтажна схема конвеєрної галереї

Навантаження на галерею підрозділялися на наступні групи: будівельні, постійні навантаження - вага несучих будівельних конструкцій i огороджування; технологічні тривалі: вага вантажу на стрічці, вага промпроводок, вага конструкцій конвеєра, опір руху стрічки; - короткочасні: ремонтні, навантаження від пуску конвеєра, вага просипі при розрахунку елементів перекриття; епізодичні - навантаження від обриву або заклинювання стрічки, вага просипі при розрахунку подовжніх несучих конструкцій пролітної будови, сейсмічні; атмосферні - тривалі: вага пилу на покритті; короткочасні: вага снігу, тиск вітру. Відповідно до [12] вітровий район 3, сніговий район 2. На підставі даних за інженерногеологічними умовами майданчика будівництва і відповідно до класу відповідальності об'єкту будівництва інтенсивність сейсмічної дії була прийнята 7 балів [13].

Для даної пролітної будови розрахунки на міцність, стійкість, деформативність i динамічні дії складаються 3 наступних етапів: збір місцевих навантажень на елементи покриття і перекриття і визначення розрахункових схем; розрахунок елементів покриття $\mathrm{i}$ перекриття на місцеві навантаження, підбір перерізів елементів за умовами міцності, стійкості і деформативності; визначення навантажень на несучі конструкції пролітних будов; розрахунок несучих конструкцій пролітних будов і підбір їх перерізів за умовами міцності, стійкості і деформативності; визначення найменших частот вільних коливань пролітних будов; визначення нижчої частоти коливань балок перекриття; визначення частот динамічного збурення галереї при швидкості стрічки конвеєра $v \geq 1 \mathrm{M} / \mathrm{c}$; зіставлення частот вільних коливань і збурення для визначення можливості появи резонансного режиму коливань; розрахунок вузлів і з'єднань пролітної будови; визначення навантажень на опори i розрахунок опор; визначення навантажень на фундаменти.

Розрахунок конструкцій виконаний за допомогою проектно-обчислювального комплексу SCAD. Комплекс реалізує кінцево-елементне моделювання статичних i динамічних розрахункових схем, перевірку стійкості, вибір невигідних поєднань зусиль [14]. Розрахункова схема у проектно-обчислювальному комплексі SCAD приведена на рис. 3. 


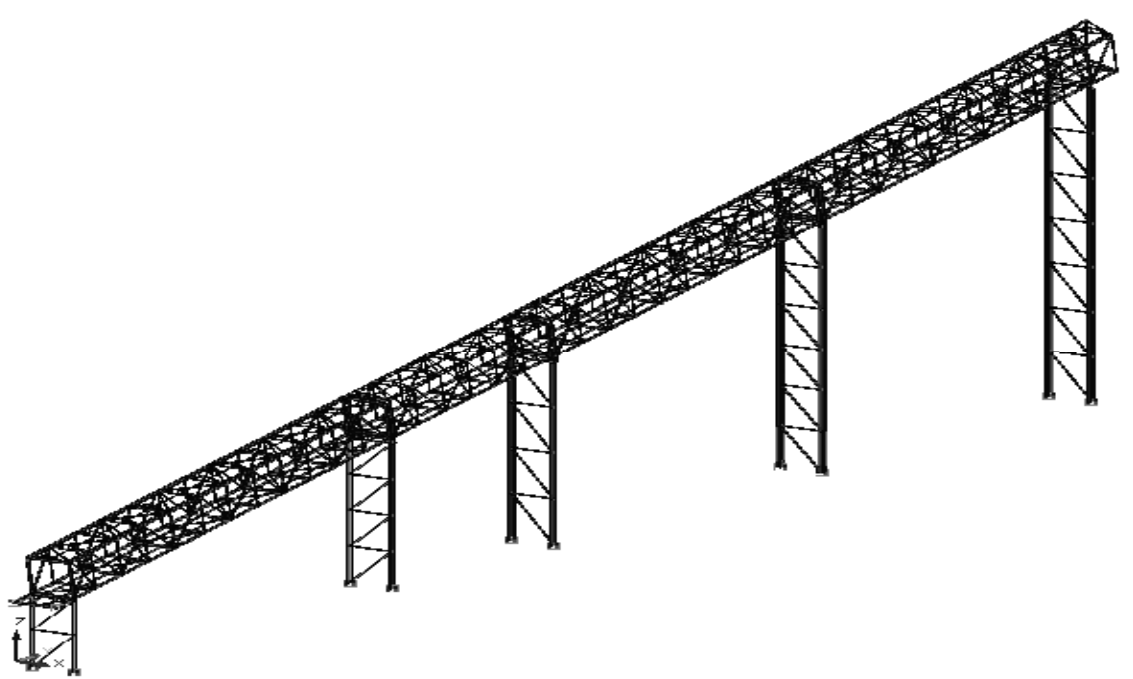

Рис. 3. Розрахункова схема конструкції конвеєрної галереї у проектно-обчислювальному комплексі SCAD

При проектуванні пролітної будови вона розділюється на плоскі системи: дві вертикальні плоскі ферми, що сприймають все навантаження в прольоті і передають його на опори; система зв'язків і поперечних балок покриття; система зв'язків і балок перекриття, що сприймають основні технологічні навантаження. Розрахунку на міцність, стійкість i деформативність підлягали наступні елементи: поперечні балки покриття - на вертикальні навантаження від маси снігу, пилу, будівельних конструкцій, промислових проводок, а також на дію подовжніх навантажень і скатних складових; поперечні балки перекриття - на вертикальні навантаження від маси будівельних і технологічних навантажень, а також на подовжні технологічні навантаження і скатні складові з врахуванням їх ексцентриситетів; вертикальні ферми - на вузлові навантаження, які передаються на них балками і зв'язками покриття і перекриття; в'язові системи по покриттю і перекриттю - на сприйняття вітрових навантажень, а також на подовжні технологічні навантаження і скатні складові; опорні рами пролітних будов, що складаються з крайніх балок покриття і опорних стійок і забезпечують геометричну незмінність і поперечну жорсткість пролітної будови - на сприйняття вітрового навантаження; опорні вузли ферм - на сприйняття і передачу реакцій з пролітної будови на рухливі і нерухому опори.

Традиційними вирішеннями несучих конструкцій пролітних будов галерей впродовж багатьох років були ферми 3 перерізами 3 парних кутиків. Таке рішення $є$ застарілим, в найменшій мірі відповідаючи вимогам економічності, зниження трудомісткості виготовлення і корозійної стійкості. Найбільшою мірою сучасним вимогам відповідають ферми з перерізами елементів із замкнутих тонкостінних гнутозварних профілів, що і було реалізовано при проектуванні. При цьому такі профілі були також застосовані і для інших елементів пролітної будови (зв'язків, балок перекриття і покриття).

Для пролітної будови ПС-1 (рис. 2), завдовжки 36 м, нижній пояс підібраний з гнутих замкнутих зварних квадратних профілів гн. $\square 140 \times 140 \times 6$, верхній пояс 3 профілю гн. $\square 160 \times 160 \times 6$, елементи решітки від гн. $\square 100 \times 100 \times 4$ до гн. $\square 140 \times 140 \times 6$, перерізи елементів опорних торцевих рам з парних швелерів №20 у «коробочку».

Для запроектованої пролітної будови 3 несучими конструкціями із ферм 3 паралельними поясами розроблено горизонтальне сполучення з опорами (рис. 4).

Перерізи гілок плоских опор прийняті з прокатного двотавра I45 (мінімальна висота перерізу визначається відстанню між осями опорних рам суміжних пролітних будов i приймається не менше $450 . .500$ мм 3 умови зручності розміщення опорних вузлів пролітних будов, рис. 4). Елементи розкісної решітки, що розташовуються в одній площині - по осі гілок, прийняті з гнутих замкнутих зварних квадратних профілів гн. $\square 100 \times 100 \times 6$ (стійки), гн. $\square 100 \times 100 \times 6$ і гн. $\square 120 \times 120 \times 6$ (розкоси). 


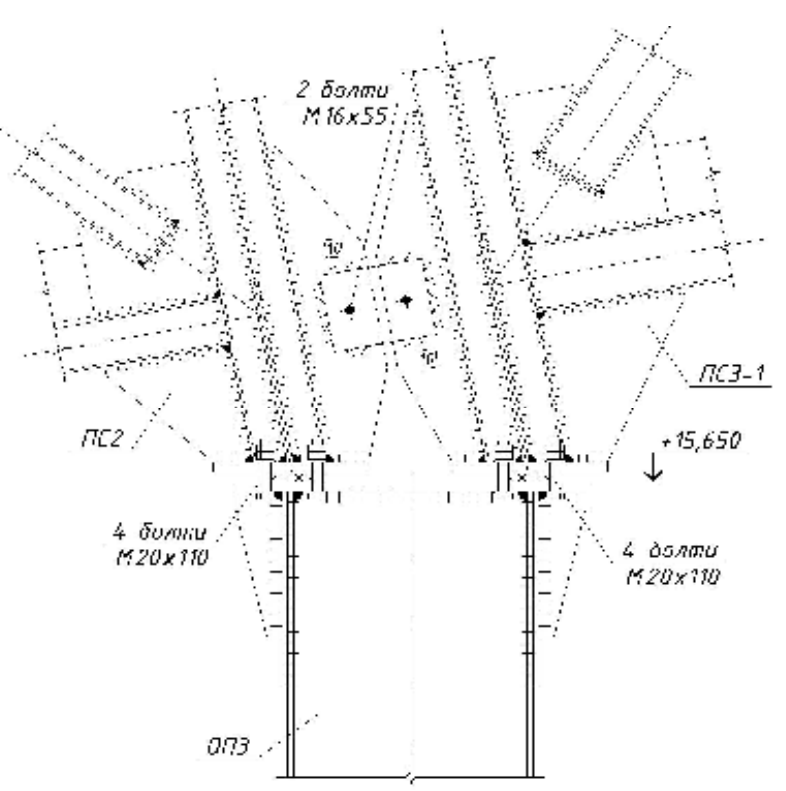

Рис. 4. Горизонтальне сполучення пролітної будови конвеєрної галереї з опорою

Альтернативно переріз гілок плоских рухомих опор конвеєрної галереї запроектовано із складеного тонкостінного двотавра з гофрованою в поперечному напрямі синусоїдальною стінкою з розмірами: стінка $-500 \times 2 ~ м м$, полиці $-200 \times 10$ мм. Економія по всіх стійках опор конвеєрної галереї в цьому випадку складе 4,2 тонни сталі.

Просторова жорсткість пролітної будови забезпечується горизонтальними зв'язками по верхніх і нижніх поясах ферм і опорними торцевими рамами кожної пролітної будови.

\section{Висновки і перспективи подальших досліджень:}

1. Вибрано раціональне конструктивне вирішення сталевої конвеєрної галереї зернового перевантажувального комплексу.

2. Перерізи елементів несучих плоских ферм пролітних будов прийняті із замкнутих тонкостінних гнутозварних профілів з безфасонковими вузлами, що відповідає вимогам економічності, зниження трудомісткості виготовлення і корозійної стійкості.

3. Перерізи гілок плоских опор запроектовані в двох варіантах - 3 прокатного двотавра i складеного тонкостінного двотавра з гофрованою синусоїдальною стінкою, 3 економією сталі в другому варіанті 4,2 тонни.

4. У перспективі планується застосовувати отриманий досвід при проектуванні сталевих конструкцій для їх раціонального використання, забезпечення надійності i довговічності.

\section{Література}

1. ДБН В.2.6 - 198:2014. Сталеві конструкції. Норми проектування. - [чинні від 201501-01]. - К.: Мінрегіон України, 2014. - 199 с. (Державні будівельні норми України).

2. Пособие по проектированию конвейерных галерей (к СНиП 2.09.03/85) / ГПИ Ленпроектстальконструкция. - М.: Стройиздат, 1989. - 111 с.

3. Руководство по проектированию транспортёрных галерей / Ленинградский Промстройпроект. - М.: Стройиздат, 1979. - 104 с.

4. Зеленский О.В., Петров А.С. Справочник по проектированию ленточных конвейеров / О.В. Зеленский, А.С. Петров. - М.: Недра, 1986. - 223 с.

5. Расчёт и проектирование пространственных конструкций / Е. В. Горохов, В. Ф. Мущанов, Я. В. Назим, И. В. Роменский. Под общей редакцией Е. В. Горохова. - Макіївка: ДонНАБА, 2012. - $561 \mathrm{c.}$ 
6. Хворост В. В. Исследования влияния различных факторов на собственную частоту колебания пролетных строений транспортных галерей / Д. В. Бровко, В. В. Хворост // Вісник КТУ. - Вип. 29. - Кривий ріг, КТУ, 2011. - С. 82-83.

7. Ним А. Д. Надёжность главных ферм транспортёрных эстакад при случайных колебаниях / А. Д. Ним // Исследование в области надёжности инженерных сооружений: Сборник трудов, Ленинградский Промстройпроект. - Л.: Стройиздат, 1979. - С. 64-68.

8. Пасынков Б. П. Динамика транспортёрных эстакад галерей / Б. П. Пасынков, А. Д. Ним // Динамический расчёт специальных инженерных сооружений и конструкций. Справочник проектировщика. Под редакцией Б. Г. Коренева, А. Ф. Смирнова. - М.: Стройиздат, 1986. - С. 349-359.

9. Кущенко В.М. Аналіз впливу динамічного характеру технологічного навантаження на напружено-деформований стан прольотної будови гратчастої конвеєрної галереї / В.М. Кущенко, М.В. Губарев // Науковий журнал «Металлические конструкции», том 19, №4. Макіївка: ДонНАБА, 2013. - С. 225-234.

10. Югов А.М. Динамические испытания моста транспортёрной галереи / А. М. Югов, С. В. Колесниченко, Д. В. Левченко // Науковий журнал «Металлические конструкции», том 6, №1. - Макіївка: ДонНАБА, 2003. - С. 35-42.

11. Баклашов И.В. Проектирование и строительство горнотехнических зданий и сооружений. Учеб. для вузов / И.В. Баклашов, В.Н. Борисов - М.: Недра, 1990. - 272 с.

12. ДБН В.1.2-2:2006. Навантаження і впливи. Норми проектування. - [чинні від 200701-01]. - К.: Мінбуд України, 2006. - 75 с. (Державні будівельні норми України).

13. ДБН В.1.1-12:2014. Будівництво у сейсмічних районах України. - [чинні від 201410-01]. - К.: Мінрегіон України, 2014. - 110 с. (Державні будівельні норми України).

14. Перельмутер А. В. Расчётные модели сооружений и возможность их анализа [Structure CAD] / А. В. Перельмутер, В. І. Слівкер. - К.: Сталь, 2002. - 597 с.

\section{References}

[1] DBN V.2.6-198:2014. Stal'nyye konstruktsii. Normy proyektirovaniya [chynni vid 2015-0101]. K.: Minrehion Ukrainy, 2014.

[2] Posobiye po proyektirovaniyu konveyyernykh galere (k SNiP 2.09.03/85). GPI Lenproyektstal'konstruktsiya. Moskva: Stroyizdat, 1989.

[3] Rukovodstvo po proyektirovaniyu transportornykh galerey. Leningradskiy Promstroyproyekt. Moskva: Stroyizdat, 1979.

[4] O.V. Zelenskiy, A.S. Petrov, Spravochnik po proyektirovaniyu lentochnykh konveyyerov. Moskva: Nedra, 1986.

[5] Ye. V. Gorokhov, V. F. Mushchanov, YA. V. Nazim, I. V. Romenskiy, Raschot $i$ proyektirovaniye prostranstvennykh konstruktsiy. Makiyivka: DonNABA, 2012.

[6] D. V. Brovko, V. V. Khvorost, "Issledovaniya vliyaniya razlichnykh faktorov na sobstvennuyu chastotu kolebaniya proletnykh stroyeniy transportnykh galerey", Visnyk KTU. Kryvyy rih, Vol. 29, pp. 82-83, 2011.

[7] A. D. Nym, "Nadozhnost' glavnykh ferm transportornykh estakad pri sluchaynykh kolebaniyakh", Issledovaniye v oblasti nadozhnosti inzhenernykh sooruzheniy: Sbornik trudov, Leningradskiy Promstroyproyekt. Leningrad: Stroyizdat, pp. 64-68, 1979.

[8] B. P. Pasynkov, A. D. Nym, "Dinamika transportornykh estakad galerey", Spravochnik proyektirovshchika. Pod redaktsiyey B. G. Koreneva, A. F. Smirnova. Moskva: Stroyizdat, pp. 349-359, 1986.

[9] V.M. Kushchenko, M.V. Gubarev, "Analiz vplyvu dynamichnoho kharakteru tekhnolohichnoho navantazhennya na napruzheno-deformovanyy stan prol'otnoyi budovy hratchastoyi konveyernoyi halereyi", Naukovyy zhurnal "Metallicheskiye konstruktsii». Makiyivka: DonNABA, Vol. 19/4, pp. 225-234, 2013. 
[10] A. M. Yugov, S. V. Kolesnichenko, D. V. Levchenko, "Dinamicheskiye ispytaniya mosta transportornoy galerei", Naukovyy zhurnal "Metallicheskiye konstruktsii». Makiyivka: DonNABA, Vol. 6/1, pp. 35-42, 2003.

[11] I.V. Baklashov, V.N. Borisov, Proyektirovaniye i stroitel'stvo gornotekhnicheskikh zdaniy i sooruzheniy. Moskva: Nedra, 1990.

[12] DBN V.1.2-2:2006. Navantazhennia i vplyvy. Normy proyektirovaniya [chynni vid 2007-0101]. K.: Minbud Ukrainy, 2006.

[13] DBN V.1.1-12:2014. Budivnytstvo u seysmichnykh rayonakh Ukrayiny [chynni vid 2014-1001]. K.: Minrehion Ukrainy, 2014.

[14] A.V. Perel'muter, Raschotnyye modeli sooruzheniy $i$ vozmozhnost' ikh analiza. Kyev: Stal', 2002.

\title{
ОСОБЕННОСТИ ПРОЕКТИРОВАНИЯ КОНВЕЙЕРНОЙ ГАЛЕРЕИ ЗЕРНОВОГО ПЕРЕГРУЗОЧНОГО КОМПЛЕКСА
}

\author{
Купченко Ю.В., к.Т.н., доцент, \\ steelconpro@gmail.com, ORCID: 0000-0003-1480-6884 \\ Сингаевский П.М., к.т.н., доцент, \\ mdipk@ukr.net, ORCID: 0000-0003-1268-414X \\ Константинов П.В., к.т.н., \\ Konstantinov31@mail.ru, ORCID:0000-0002-8478-2980 \\ Одесская государственная академия строительства и архитектуры
}

\begin{abstract}
Аннотация. Одной из важных задач в области совершенствования строительных металлических конструкций является снижение их материалоемкости, что может быть достигнуто на основе дальнейшего изучения действительной работы конструкций, совершенствования расчетных схем, развития конструктивной формы, применения высокопрочных сталей, использования эффективных типов поперечных сечений элементов.

В статье авторы исследуют вопрос назначения рационального конструктивного решения конвейерной галереи зернового перегрузочного комплекса морского торгового порта.
\end{abstract}

Проектируемая конвейерная галерея имеет длину $118,69 \mathcal{M}$ и состоит из четырех пролетных строений (длиной $36,18,30,30$ ) и пяти опор высотой 5,86 $м, 12,39$ м, 15,65 $м$, $21,16 м, 26,68 \mu$, продольный уклон галереи составляет $12^{\circ}$. Галерея принята из одного температурного блока. При этом неподвижной опорой, обеспечивающей устойчивость конструкции в продольном направлении, принята существующая перегрузочная станция, остальные опоры приняты плоскими, допускающими смещение в продольном направлении при температурных перемещениях. Из разнообразных возможных конструктивных решений пролетного строения принята конструкция из ферм, как наиболее технологичная и обладающая простотой монтажа. Пролетные строения выполняются по разрезной схеме и состоят из двух плоских несущих ферм высотой 3,2 $\mathcal{~ с ~ п а р а л л е л ь н ы м и ~ п о я с а м и ~ и ~}$ треугольной решеткой с дополнительными стойками, соединенных между собой в объемный пространственный блок шириной 3,3 м поперечными балками покрытия и перекрытия, горизонтальными связями по нижним и верхним поясам ферм и опорными рамами по торцам, имеющими жесткое соединение ригеля с опорными стойками несущих ферм. Найдены нагрузки, действующие на галерею - строительные, технологические, атмосферные, в том числе эпизодические - сейсмические воздействия (на основании данных по инженерно-геологическим условиям площадки строительства и в соответствии с классом ответственности объекта строительства интенсивность сейсмического воздействия была принята 7 балов). Расчет стальных конструкций конвейерной галереи выполнен с помощью проектно-вычислительного комплекса SCAD. B соответствии с требованиями экономичности, снижения трудоемкости изготовления и коррозионной стойкости сечения 
стержней ферм запроектированы из замкнутых тонкостенных гнутосварных профилей. Такие же профили были также применены и для других элементов пролетного строения - балок перекрытия, покрытия, элементов связей. Запроектированы плоские двухветвевые опоры с одноплоскостной раскосной соединительной решеткой. Сечения ветвей опор запроектированы в двух вариантах - из прокатного двутавра I45 и альтернативно из составного тонкостенного двутавра с гофрированной синусоидальной стенкой. Экономия по всем стойкам опор конвейерной галереи для второго варианта составила 4,2 тонны стали.

Ключевые слова: конвейерная галерея, нагрузка, пролетное строение, ферма, верхний пояс, нижний пояс, решетка, сечение, опора.

\title{
SPECIAL ASPECTS OF THE GRAIN HANDLING TERMINAL'S CONVEYOR GALLERY DESIGNING
}

\author{
Kupchenko Y.V., PhD., Assistant Professor, \\ steelconpro@gmail.com, ORCID: 0000-0003-1480-6884 \\ Singayevsky P. M., PhD., Assistant Professor, \\ mdipk@ukr.net, ORCID: 0000-0003-1268-414X \\ Konstantinov P.V., PhD., \\ Konstantinov31@mail.ru, ORCID: 0000-0002-8478-2980 \\ Odessa State Academy of Civil Engineering and Architecture
}

\begin{abstract}
One of the important tasks in the field of metal structures improving is to reduce their material consumption, which can be achieved by further studying the actual work of structures, improving design schemes, developing a structural form, using high-strength steels, and using effective cross sections types of elements.

In the article, the authors investigate the question of rational constructive solutions for the conveyor gallery of the grain handling terminal of the sea trade port.

The length of designed conveyor gallery is $118.69 \mathrm{~m}$ and it consists of four spans $(36,18,30$, $30 \mathrm{~m}$ long) and five supports $5.86 \mathrm{~m}, 12.39 \mathrm{~m}, 15.65 \mathrm{~m}, 21.16 \mathrm{~m}, 26.68 \mathrm{~m}$ high, the gallery has a longitudinal grade of $12^{\circ}$. Gallery consists of the one temperature unit. At the same time, an existing handling station is adopted by a fixed support providing structural stability in the longitudinal direction, the remaining supports are adopted flat, allowing displacement in the longitudinal direction during temperature movements. A truss structure has been adopted among the various possible structural solutions for the span structure, as the most technologically advanced and easy to install. Spans are carried out according to a discontinuous design and consist of two flat supporting trusses with a height of $3.2 \mathrm{~m}$ with parallel belts and a triangular lattice with additional posts connected to each other in a three-dimensional space block with a width of $3.3 \mathrm{~m}$ by transverse beams of covering and overlapping, horizontal ties along the lower and upper truss belts and supporting frames at the ends having a rigid connection of the crossbar with the supporting posts of the supporting trusses. The loads acting on the gallery - erection load, technological, atmospheric, including episodic - seismic effects were found (the intensity of seismic impact was adopted 7 points, based on the data of the building area's geotechnical conditions and in accordance with the class of responsibility of the construction object). Calculation of steel structures of the conveyor gallery was performed using the computer-aided engineering system SCAD. The sections of truss rods are designed with rectangular roll-welded slender hollow section, in accordance with the requirements of economy, reducing the complexity of manufacturing and corrosion resistance. The same profiles were also applied to other span elements - floor beams, roofs, and tie elements. Flat two-member supports with a single-plane diagonal connecting grid were designed. Crosssections of the supports are designed in two versions - with the hot rolled I-beams №45 and alternatively from a composite light formed I-beam with a corrugated sinusoidal wall. The savings on all posts of conveyor gallery supports for the second version make 4.2 tons of steel.
\end{abstract}

Keywords: conveyor gallery, load, span, truss, upper belt, lower belt, lattice, section, support. 


\title{
ПРАКТИЧНІ ПІДХОДИ ДО РОЗРАХУНКУ КОНІЧНИХ ПОКРІВЕЛЬ СТАЛЕВИХ СИЛОСНИХ СМНОСТЕЙ
}

\author{
Махінько А.В., д.т.н., с.н.с. \\ ТОВ «Етуаль» \\ pasargada1981@gmail.com, ORCID 0000-0002-9147-7087 \\ Махінько Н.О., к.т.н. \\ Наџіональний авіаційний університет \\ pasargada1985@gmail.com, ORCID 0000-0001-8120-6374
}

\begin{abstract}
Анотація. Дана стаття присвячена дослідженню параметрів напружено-деформованого стану елементів конічних покрівель циліндричних силосів виконаних 3 тонколистових сталевих конструкцій. На практичному прикладі, розглядаються аспекти застосування аналітичного розрахунку внутрішніх зусиль та переміщень для головних радіальних ребр покрівель, виконаних у вигляді ферм з паралельними поясами. Проілюстровані особливості врахування в розрахунковій схемі ребра присутності кільцевих ребер жорсткості, а також запропонована спрощена процедура оцінки діючих навантажень, що полягає у застосуванні еквівалентного навантаження 3 визначеними параметрами. Числова реалізація дозволяє виконати оцінку точності даного розрахунку та свідчить про простоту його виконання, порівняно з комп'ютерною процедурою на основі методу скінчених елементів.
\end{abstract}

Ключові слова. силос, конічна покрівля, головне радіальне ребро, опорна обичайка, кільця жорсткості, напружено-деформований стан.

Вступ. Сучасні проектно-розрахункові комплекси міцнісного аналізу на основі методу скінчених елементів, дозволяють досить легко та 3 достатньою точністю виконувати розрахунок параметрів напружено-деформованого стану будівельних конструкцій. Проте в деяких випадках виникають задачі, коли використання комп'ютеризованого апарату введення даних, навпаки ускладнює процес рішення. В якості такого прикладу, можна привести оптимізаційні завдання конструкторського пошуку оптимального співвідношення геометричних розмірів несучих конструкцій покрівель ємностей зберігання, які практично завжди утворені тонкостінними профілями різного поперечного перерізу. В процесі встановлення кращих параметрів, інженер стикається 3 проблемами багатоваріантного геометричного моделювання перерізів 3 наступним визначенням їх геометричних характеристик, багаторазовими змінами розрахункової схеми та, відповідно, новими процедурами прикладення навантажень та ін. Альтернативним є вирішення такого завдання в простій формі аналітичного розрахунку, результат якого хоча і матиме меншу точність, проте значно зменшить як часову, так і трудову завантаженість конструктора. В подальшому, знайдені рішення, можуть бути верифіковані та уточнені шляхом розрахунку методами скінчено-елементного аналізу.

Аналіз останніх досліджень і публікацій. Методи аналітичного розрахунку будівельних конструкцій історично є базисом наукових досліджень даної галузі науки [1, 2, 3]. Ускладнення інженерних задач з одного боку та загальний технічний прогрес 3 іншого, призвели до масової популяризації комп'ютерних програм для будівельного проектування, які в реаліях сьогодення за функціональними можливостями можуть бути використані для вирішення практично всіх інженерних задач $[4,5,6]$. Не $\epsilon$ винятком і розрахунок тонкостінних конструкцій, дослідженням яких в останні роки приділяється досить багато уваги $[7,8]$. Проте в області проектування та розрахунку конструкцій сталевих силосів для потреб аграрного сектору, дана проблематика порушується значно рідше [9, 10, 11].

Постановка проблеми. Інженерний розрахунок несучих конструкцій конічних покрівель методами будівельної механіки з урахуванням ряду спрощуючих передумов не 
викликає особливих ускладнень $[9,10]$. Проте варто розглянути ряд практичних питань, які виникають у випадку конструктивного вирішення головного радіального ребра покрівлі (крокви) у вигляді ферми. Переважно такий тип використовується для силосів 3 габаритними розмірам діаметрів від 25 м і передбачає в конструкції покрівлі наявність трьох кілець жорсткості.

Мета та завдання. Основною метою даного дослідження є ілюстрація особливостей практичного аналітичного розрахунку елементів каркасу конічної покрівлі сталевої силосної ємності, що виконані у вигляді ферм з паралельними поясами. За основу розрахунку використаємо дослідження, виконані авторами в роботах $[10,11]$ з урахуванням ряду припущень, щодо співосності радіальних ребер покрівлі та вертикальних ребер жорсткості й використанні еквівалентного нерівномірно розподіленого навантаження на всій довжині головного радіального ребра.

Матеріали і методика досліджень. Просторова система конструкції конічної покрівлі сталевої силосної ємності утворена прямолінійними кроквяними ребрами, які розміщені в радіальному напрямку та спираються з одного боку на центральне жорстке кільце, а іншим кінцем на кільце жорсткості, що розташоване в місці спряження покрівлі та стіки ємності Конструктивно ребра виконуються у двох варіантах - у вигляді балки тонкостінного профілю

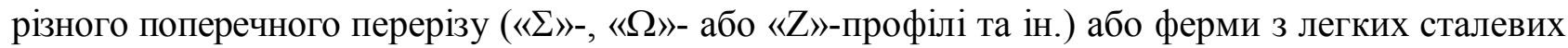
тонкостінних конструкцій (рис. 1).

Розрахункова схема головного радіального ребра утвореного балкою 3 трьома проміжними кільцями жорсткості $\left(n_{R}=3\right)$ буде мати вигляд похилого стрижня довжиною $\ell_{M} 3$ двома шарнірно-рухомими опорами на кінцях, а в рівні спирання ребра на корпус ємності (т. $A$ ) буде присутня умовна затяжка кінцевої жорсткості ( $E A_{30}$ та $E J_{30}$ ) (див. рис. 2).

a)

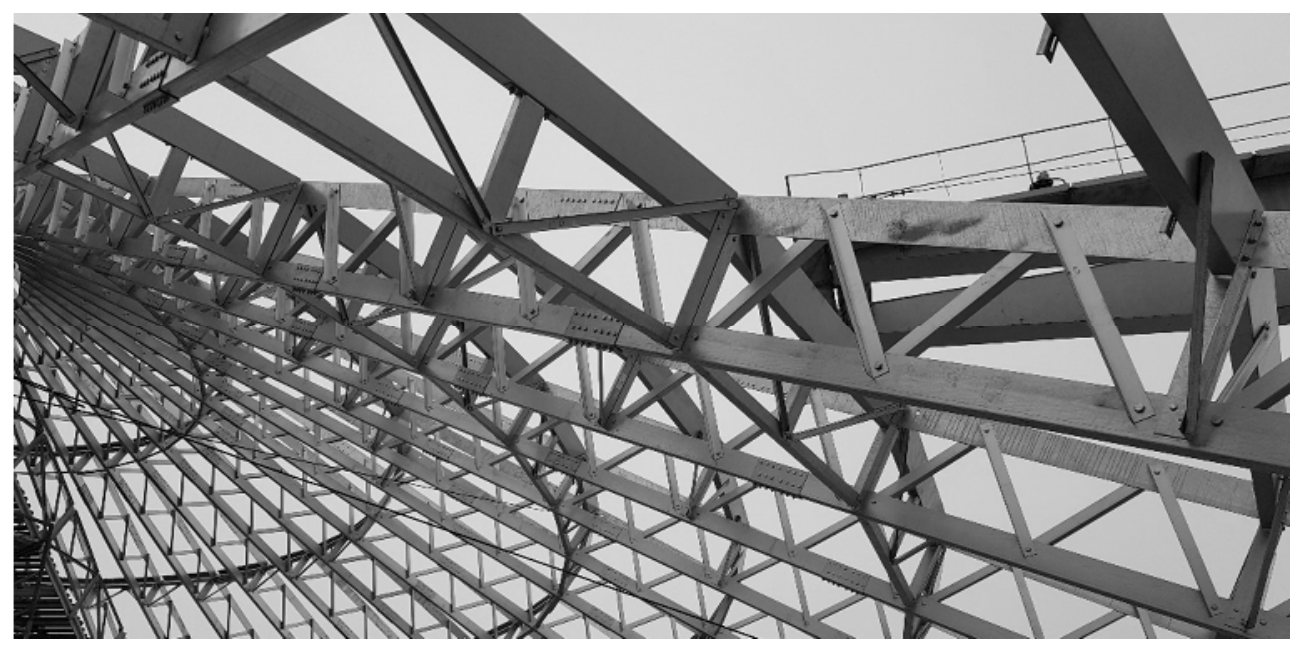

б)

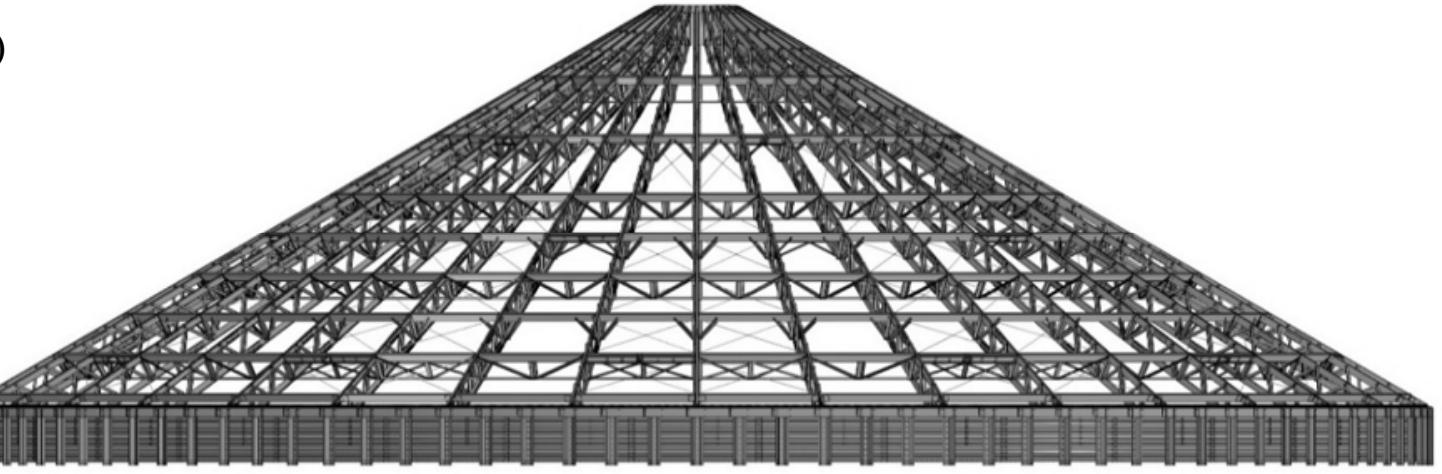


Рис. 1. Просторова система конструкції конічної покрівлі силоса: а - головні ребра у вигляді ферм з паралельними поясами; б - загальна розрахункова схема покрівлі

Довжина головної радіальної балки буде залежати від кута нахилу покрівлі до горизонту $\beta$ та відношення $\Delta_{D}=d_{0} / D_{w}$ діаметру центрального кільця жорсткості $d_{0}$ до діаметру ємності $D_{w}$ (або співвідношення відповідних радіусів $\Delta_{D}=r_{0} / R_{w}$ ).

$$
\ell_{M}=R_{w}\left(1-\Delta_{D}\right) / \cos \beta \text {. }
$$

Проміжні кільця жорсткості, утворені кільцевими балками, в розрахунковій схемі головної балки замінені затяжками 3 приведеними поздовжньою та згинальною жорсткістю ( $E A_{3 i}$ та $E J_{3 i}$ ). Положення кожного буде визначатися частковими коефіцієнтами $\alpha_{j}$. Власне довжина кільцевої балки $j$-го ярусу знаходитиметься за формулою

$$
\ell_{R, j}=\pi D_{w}\left[1-\alpha_{j}\left(1-\Delta_{D}\right)\right] / n_{M} .
$$

За довжиною головне ребро розбивається на чотири ділянки $(A G, G H, H K, K B)$, на кожній з яких діє розподілене трапецієвидне навантаження від власної ваги конструкцій та ваги снігового покриву і зосереджені сили $V_{G}, V_{H}$ та $V_{K}$, які схематизують опорний тиск кільцевих ребер першого, другого та третього ярусів (рис. 2а). Однією 3 передумов аналітичного розрахунку за такою схемою $є$ заміна чотирьох ділянок дії нерівномірно розподіленого навантаження одним, еквівалентної дії $\left(q_{A, \text { eqv }}-q_{B, \text { eqv }}\right)$, відповідно рис. 26.

a)

б)
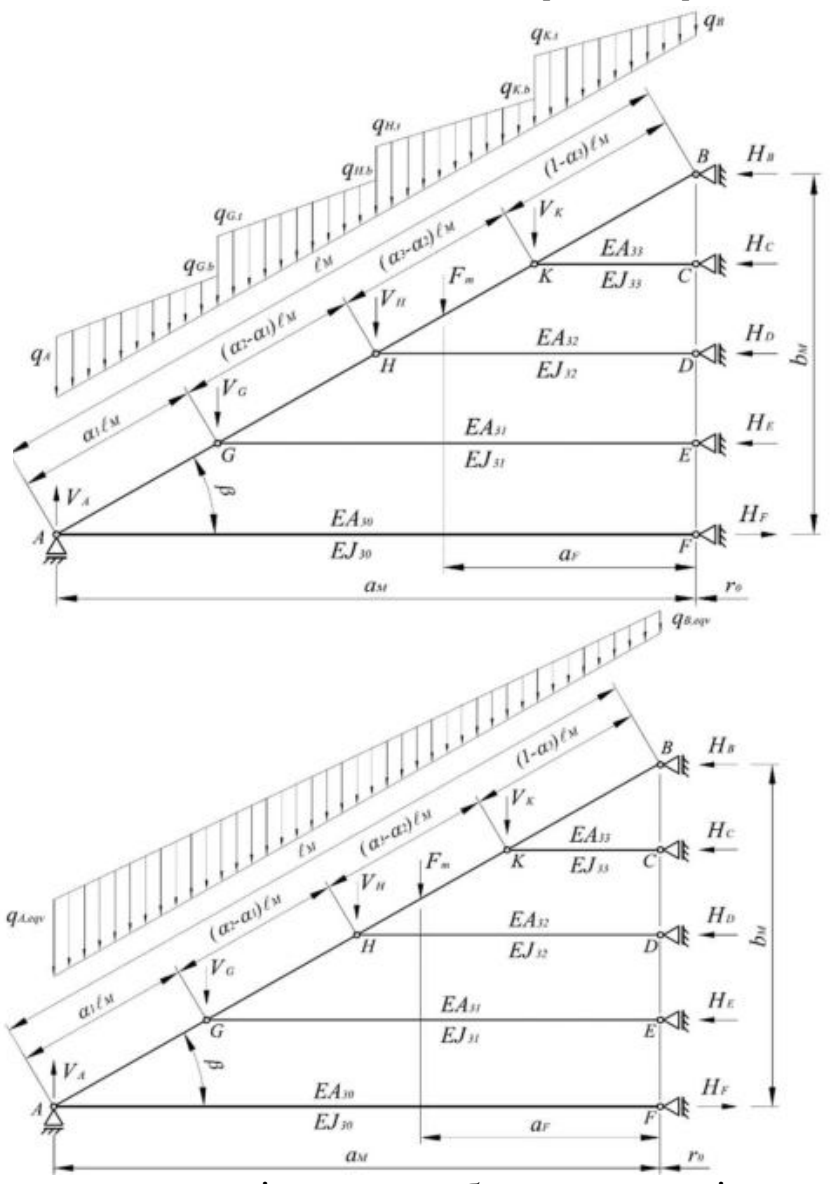

Рис. 2. Розрахункова схема головного радіального ребра жорсткості для покрівель $з$ трьома проміжними кільцями жорсткості та другорядними балками: а - загальна схема прикладення навантаження; б - еквівалентне навантаження

За довжиною головне ребро розбивається на чотири ділянки $(A G, G H, H K, K B)$, на кожній з яких діє розподілене трапецієвидне навантаження від власної ваги конструкцій та ваги снігового покриву і зосереджені сили $V_{G}, V_{H}$ та $V_{K}$, які схематизують опорний тиск кільцевих ребер першого, другого та третього ярусів (рис. 2а). Однією 3 передумов 
аналітичного розрахунку за такою схемою є заміна чотирьох ділянок дії нерівномірно розподіленого навантаження одним, еквівалентної дії ( $\left.q_{A, \text { eqv }}-q_{B, \text { eqv }}\right)$, відповідно рис. 26.

Пошук невідомих внутрішніх зусиль в даній розрахунковій схемі виконується методом сил. Дане дослідження та загальний алгоритм розрахунку були наведені в роботах авторського колективу $[10,11]$.

Результати досліджень. Для циліндричних ємностей, які характеризуються особливо великими розмірами, доцільно виконувати головні ребра у вигляді ферм. Найчастіше застосовується варіант ферми з паралельними поясами, розрахункова схема яких матиме наступний вигляд (рис. 3). Проілюструємо можливість застосування методики досліджень $[10,11]$ на прикладі перевірочного розрахунку головного радіального ребра покрівлі силосу діаметром $D_{w}=27,5$ м. Ребро виконане у вигляді ферми 3 паралельними поясами, рознесеними на відстань $h_{f}=700$ мм і шарнірно закріпленими до опорної обичайки $\mathrm{i}$ центрального кільця в точках верхнього поясу (див. рис. 3).

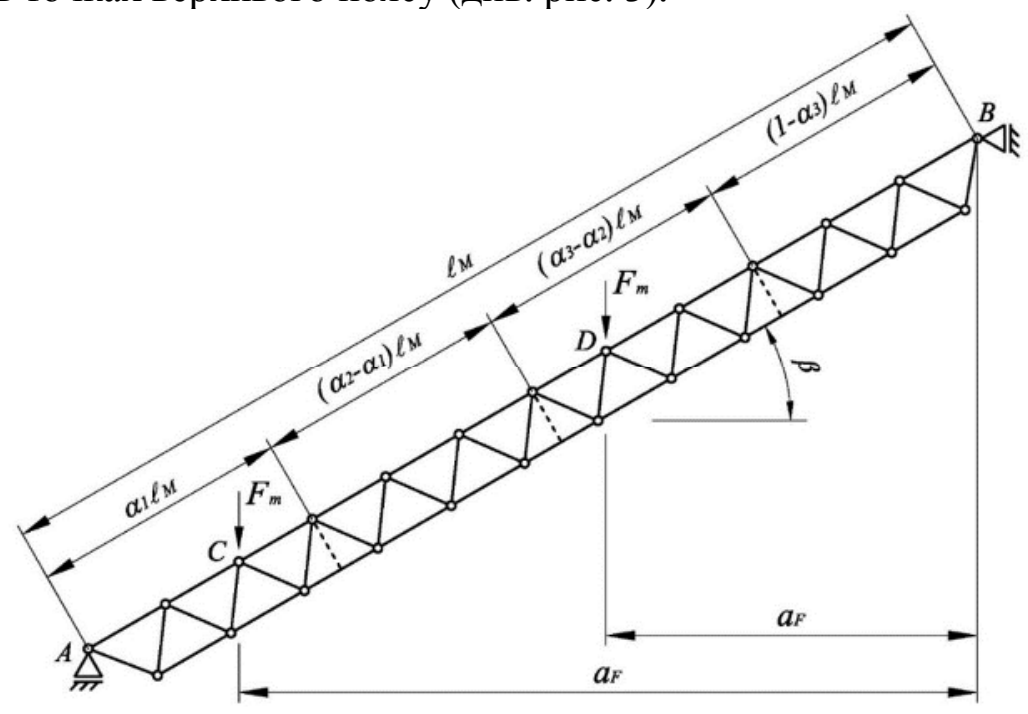

Рис. 3. Схема головного радіального ребра жорсткості покрівлі силосу

Покрівля має ухил $\beta=30^{\circ}$ і передбачає постановку трьох кілець жорсткості таким чином, що $\alpha_{1}=0,25, \alpha_{2}=2 \alpha_{1}$ і $\alpha_{3}=3 \alpha_{1}$. Загальна кількість головних радіальних ребер за периметром покрівлі $n_{M}=30$. Діаметр центрального кільця жорсткості $d_{0}=1800$ мм. Розрахунок виконаємо на загальне розподілене навантаження $g_{\Sigma}=1$ кПа і зосереджену силу $F_{m}=30$ кН від ваги термопідвісок в двох можливих положеннях, вказаних на рис. 3.Площі елементів покрівлі наведені в таблиці 1.

На першому етапі замінюємо ферму балкою еквівалентного моменту інерції. Так як площі поясів відрізняються, спершу необхідно визначити ординату центру ваги 3 наступного співвідношення

$$
\begin{gathered}
y_{f}=\frac{A_{f b} h_{f}}{A_{f t}+A_{f b}} . \\
J_{p} \approx A_{f t} y_{f}^{2}+A_{f b}\left(h_{f}-y_{f}\right)^{2} .
\end{gathered}
$$

Таблиця 1.

Площі основних елементів покрівлі силосу $D_{w}=27,5 \mathrm{M}$

\begin{tabular}{|c|c|c|c|c|c|}
\hline \multicolumn{2}{|c|}{ Пояси ферми } & \multicolumn{2}{|c|}{ Кільцеві ребра жорсткості } & \multirow{2}{*}{ Опорна } \\
\cline { 1 - 4 } верхній & нижній & 1-го ярусу & 2-го ярусу & 3-го ярусу & обичайка \\
\hline
\end{tabular}




\begin{tabular}{|l|l|l|l|l|l|}
\hline$A_{f t}=10 \mathrm{~cm}^{2}$ & $A_{f b}=5 \mathrm{~cm}^{2}$ & $A_{k 1}=7,5 \mathrm{~cm}^{2}$ & $A_{k 2}=9 \mathrm{~cm}^{2}$ & $A_{k 3}=9 \mathrm{~cm}^{2}$ & $A_{k 0}=30 \mathrm{~cm}^{2}$ \\
\hline
\end{tabular}

Відповідно до (3) та (4) для заданого ребра $y_{f}=23,3 \mathrm{~cm} ; J_{p}=16333,3 \mathrm{~cm}^{4}$.

Встановивши відношення $\Delta_{D}=d_{0} / D_{w}=0,065$, за (1) і (2) обчислюємо довжину головної балки, довжини кільцевих ребер жорсткості $j$-го ярусу) та довжини умовних затяжок $j$-го ярусу (при $j=1,2,3$ )

$$
\begin{gathered}
\ell_{M}=0,5 D_{w}\left(1-\Delta_{D}\right) / \cos \beta=14838 \text { мм, } \\
\ell_{R, j}=\pi D_{w}\left[1-\alpha_{j}\left(1-\Delta_{D}\right)\right] / n_{M}=\begin{array}{ccc}
j=1 & j=2 & j=3 \\
2207 \mathrm{MM} & 1534 \mathrm{MM} & 861,3 \mathrm{MM}, \\
\ell_{R, j}=0,5 D_{w}\left(1-\alpha_{j}\right)\left(1-\Delta_{D}\right)=\begin{array}{c}
j=1 \\
9637,5 \mathrm{MM}
\end{array} & j=2 & j=3 \\
6425 \mathrm{MM} & 3212,5 \mathrm{MM} .
\end{array}
\end{gathered}
$$

Обчислюємо безрозмірні параметри навантажень, за схемою рис. 2a, як функцію параметру $\alpha_{j}$ (в даному випадку і в подальшому $\alpha_{j=0}=0$ )

$$
\begin{gathered}
q_{0}=\pi D_{w}\left(g_{m}+S_{m}\right) / n_{M}, \\
q_{B}=\pi d_{0}\left(g_{m}+S_{m}\right) / n_{M}=q_{0} \Delta_{D}, \\
q_{A}=q_{0} / 3,
\end{gathered}
$$

де $g_{m}$ - власна вага конструкцій даху; $S_{m}-$ снігове навантаження; $\left(g_{m}+S_{m}\right)=g_{\Sigma}=1$ кПа.

Маємо $q_{0}=2,88 \kappa \mathrm{K} / \mathrm{M}, \quad q_{A}=0,96 \kappa \mathrm{H} / \mathrm{M}, \quad q_{B}=0,188 \kappa \mathrm{K} / \mathrm{M}$.

$$
\begin{aligned}
& \Delta=q_{G . b} / q_{A}, \quad \Delta_{2}=q_{H . b} / q_{G . t}, \quad \Delta_{3}=q_{K . b} / q_{H . t} \text {, } \\
& \Delta_{j}=\frac{1-\alpha_{j}\left(1-\Delta_{D}\right)}{1-\alpha_{j-1}\left(1-\Delta_{D}\right)}=\begin{array}{ccc}
j=1 & j=2 & j=3 \\
0,766 & 0,695 & 0,561 .
\end{array}
\end{aligned}
$$

Визначаємо реакції другорядних радіальних ребер жорсткості

$$
\begin{gathered}
V_{G}=2\left(V_{G . b}+V_{G . t}\right), \quad V_{H}=2 V_{H . b}+V_{H . t}, \quad V_{K}=V_{K . b} . \\
V_{G . b}=q_{A} \alpha_{1} \ell_{M}\left(2+\Delta_{1}\right) / 6 . \\
V_{G . t}=q_{G . t}\left(\alpha_{2}-\alpha_{1}\right) \ell_{M}\left(2+\Delta_{2}\right) / 6, \quad V_{H . b}=q_{G . t}\left(\alpha_{2}-\alpha_{1}\right) \ell_{M}\left(1+2 \Delta_{2}\right) / 6, \\
V_{H . t}=q_{H . t}\left(\alpha_{3}-\alpha_{2}\right) \ell_{M}\left(2+\Delta_{3}\right) / 6, \quad V_{K . b}=q_{H . t}\left(\alpha_{3}-\alpha_{2}\right) \ell_{M}\left(1+2 \Delta_{3}\right) / 6 .
\end{gathered}
$$

Маємо $V_{G . b}=1,50 \kappa \mathrm{H}, \quad V_{G . t}=1,23 \kappa \mathrm{H}, \quad V_{H . b}=1,09 \kappa \mathrm{H}, \quad V_{H . t}=1,22 \kappa \mathrm{H}, \quad V_{K . b}=1,0 \kappa \mathrm{H}$.

За формулами (10) визначаємо тиск кільцевих ребер

$$
V_{G}=5,46 \kappa \mathrm{H}, \quad V_{H}=3,4 \kappa \mathrm{H}, \quad V_{K}=1,0 \kappa \mathrm{H} .
$$

Обчислюємо погонні жорсткості головного ребра та чотирьох умовних затяжок

$$
\begin{gathered}
E A_{3}=2 \pi E A_{k} / n_{M}, \quad E J_{3}=2 \pi E J_{k} / n_{M} . \\
I_{M}=\frac{E J_{M}}{\ell_{M}^{3}}, \quad I_{30}=\frac{2 E A_{30}}{D_{w}}, \quad I_{31}=\frac{E A_{31}}{\ell_{31}}, \quad I_{32}=\frac{E A_{32}}{\ell_{32}}, \quad I_{32}=\frac{E A_{33}}{\ell_{33}} .
\end{gathered}
$$

$I_{M}=10,3 \kappa \mathrm{H} / \mathrm{M}, \quad I_{30}=9413 \kappa \mathrm{H} / \mathrm{M}, \quad I_{31}=3358 \kappa \mathrm{H} / \mathrm{M}, \quad I_{32}=6044 \kappa \mathrm{H} / \mathrm{M}, \quad I_{33}=12087 \kappa \mathrm{K} / \mathrm{M}$.

Застосовуючи вирази для внутрішніх зусиль в основній системі методу сил для головних радіальних ребер покрівель $[10,11]$, записуємо формули для зусиль в головному радіальному ребрі від одиничних сил, обмежуючись поздовжньою силою та моментом

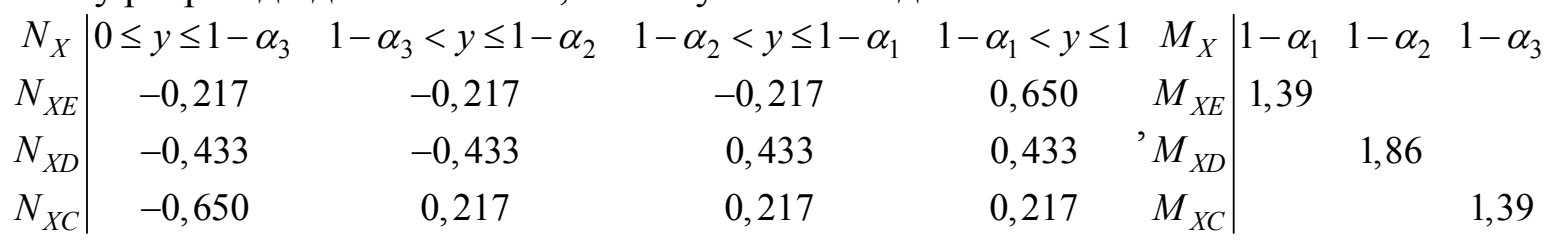


Обчислюємо параметри еквівалентного розподіленого навантаження

$$
\begin{gathered}
V_{q, A}=0,083 q_{0} \ell_{M}\left[\left(1-\Delta_{D}\right)\left(\alpha_{2}^{2}+3 \alpha_{3}^{2}\right)-2\left(\alpha_{2}+3 \alpha_{3}\right)+6\left(1+\Delta_{D}\right)\right] . \\
H_{q, B}=-H_{q, E}=\left[q_{0} \ell_{M} /(36 \operatorname{tg} \beta)\right]\left[2\left(1-\Delta_{D}\right)\left(\alpha_{2}^{3}+3 \alpha_{3}^{3}\right)-3\left(\alpha_{2}^{2}+3 \alpha_{3}^{2}\right)+6\left(1+2 \Delta_{D}\right)\right] . \\
q_{A, \text { eqv }}=\left(4 V_{q, A}-6 H_{q, B} \operatorname{tg} \beta\right) / \ell_{M}, \quad \Delta_{e q v}=-\left(3 H_{q, B} \operatorname{tg} \beta-V_{q, A}\right) /\left(3 H_{q, B} \operatorname{tg} \beta-2 V_{q, A}\right) .
\end{gathered}
$$

Остаточно отримуємо $q_{A, e q v}=0,881 \kappa \mathrm{H} / \mathrm{M} ; \Delta_{\text {eqv }}=0,417$.

Для функцій зусиль в основній системі від еквівалентного розподіленого навантаження та зосереджених сил від термопідвісок в двох можливих положеннях отримаємо наступні співвідношення

$$
\begin{aligned}
& N_{p, q}(y)=-\left(1,72 y^{2}+3,09 y+6,36\right), \quad M_{p, q}(y)=-\left(14,73 y^{3}+3,975 y^{2}-54,48 y\right) \\
& y_{F 1}=1-1 / 12=0,833, \quad y_{F 2}=1-7 / 12=0,417 \text {, } \\
& N_{F}(y) \quad 0 \leq y \leq y_{F} \quad y_{F}<y \leq 1 \\
& M_{F}(y) \quad 0 \leq y \leq y_{F} \quad y_{F}<y \leq 1 \\
& N_{F 1}(y) \quad-7,50 \kappa \mathrm{H} \quad-22,50 \kappa \mathrm{H} \text {, } \\
& M_{F 1}(y) \quad 64,26 \kappa{ }^{2} \quad 321,24(1-y) \text { кНм . } \\
& N_{F 2}(y)-26,25 \kappa \mathrm{H}-41,25 \kappa \mathrm{H} \\
& M_{F 2}(y) \quad 224,88 \kappa \mathrm{Нм} \quad 160,62(1-y) \kappa Н м
\end{aligned}
$$

Помітно, що друге положення більш небезпечне, тому приймаємо його в якості розрахункового.

За аналогічною процедурою конкретизуємо функції зусиль від тиску кільцевих ребер жорсткості (для моментів приводимо максимуми)

$$
\begin{array}{c|ccccc|rrr}
N_{V} & 0 \leq y \leq 1-\alpha_{3} & 1-\alpha_{3}<y \leq 1-\alpha_{2} & 1-\alpha_{2}<y \leq 1-\alpha_{1} & 1-\alpha_{1}<y \leq 1 & M_{V} & 1-\alpha_{1} & 1-\alpha_{2} & 1-\alpha_{3} \\
N_{V G} & -2,047 & -2,047 & -2,047 & -4,776 & M_{V G} & 13,15 & & \\
N_{X H} & -2,542 & -2,542 & -4,236 & -4,236 & M_{V H} & 10,90 & \\
N_{X K} & -1,133 & -1,636 & -1,636 & -1,636 & M_{V K} & & & \\
& & & & & &
\end{array}
$$

Визначаємо горизонтальні переміщення точок відкинутих в'язей в основній системі. Для порівняльного аналізу розрахунки проводимо у вигляді дробу, в чисельнику якого наведені значення, обчислені з урахуванням жорсткості умовних затяжок, в знаменнику - без них

$$
\delta_{11}=\frac{0,638}{0,284} ; \quad \delta_{12}=\frac{0,385}{0,348} ; \quad \delta_{13}=\frac{0,240}{0,221} ; \quad \delta_{22}=\frac{0,696}{0,506} ; \quad \delta_{23}=\frac{0,360}{0,348} ; \quad \delta_{33}=\frac{0,373}{0,284} \quad\left[\frac{\mathrm{MM}}{\mathrm{\kappa H}}\right] .
$$

На даному етапі, без побудови просторової розрахункової схеми, видно, що жорсткість опорного кільця (опорної обичайки) буде досить суттєво впливати на спектр зусиль в головному радіальному ребрі. Тому після прийняття остаточного рішення про переріз опорного кільця, обов'язково має бути виконаний перерахунок головного радіального ребра покрівлі. Для решти переміщень отримуємо

$$
\begin{array}{llll}
\Delta_{q}=\frac{3,267}{3,813} ; & \Delta_{2 q}=\frac{4,905}{5,270} ; & \Delta_{3 q}=\frac{3,513}{3,696} ; & {[\mathrm{MM}],} \\
\Delta_{V}=\frac{4,623}{5,115} ; & \Delta_{2 V}=\frac{6,533}{6,861} ; & \Delta_{3 V}=\frac{4,464}{4,628} ; & {[\mathrm{MM}],} \\
\Delta_{F}=\frac{14,470}{16,726} ; & \Delta_{2 F}=\frac{23,737}{25,241} ; & \Delta_{3 F}=\frac{17,556}{18,308} ; & {[\mathrm{MM}] .}
\end{array}
$$

Можна помітити, що переміщення від фактичних навантажень менш чутливі до жорсткості умовних затяжок та ними можна знехтувати (мається на увазі жорсткість затяжки в рівні нижньої опори, оскільки лише вона фігурує у формулах)

Невідомі опорні реакції оцінюємо за наступними співвідношеннями. У фігурних дужках в чисельнику вказане значення, що обчислене без урахування жорсткості умовних 
затяжок, а в знаменнику - 3 урахуванням жорсткості лише при обчисленні одиничних переміщень.

$$
\begin{aligned}
& H_{E}=\left[\Delta_{1 \Sigma}\left(\delta_{23}^{2}-\delta_{22} \delta_{33}\right)+\Delta_{2 \Sigma}\left(\delta_{12} \delta_{33}-\delta_{13} \delta_{23}\right)+\Delta_{3 \Sigma}\left(\delta_{13} \delta_{22}-\delta_{12} \delta_{23}\right)\right] / \Sigma \delta, \\
& H_{D}=\left[\Delta_{1 \Sigma}\left(\delta_{12} \delta_{33}-\delta_{13} \delta_{23}\right)+\Delta_{2 \Sigma}\left(\delta_{13}^{2}-\delta_{11} \delta_{33}\right)+\Delta_{3 \Sigma}\left(\delta_{11} \delta_{23}-\delta_{12} \delta_{13}\right)\right] / \Sigma \delta \text {, } \\
& H_{C}=\left[\Delta_{1 \Sigma}\left(\delta_{13} \delta_{22}-\delta_{12} \delta_{23}\right)+\Delta_{2 \Sigma}\left(\delta_{11} \delta_{23}-\delta_{12} \delta_{13}\right)+\Delta_{3 \Sigma}\left(\delta_{12}^{2}-\delta_{11} \delta_{22}\right)\right] / \Sigma \delta \text {, } \\
& \Sigma \delta=\delta_{33} \delta_{12}^{2}-2 \delta_{12} \delta_{13} \delta_{23}+\delta_{22} \delta_{13}^{2}+\delta_{11} \delta_{23}^{2}-\delta_{11} \delta_{22} \delta_{33} \text {. } \\
& H_{E}=\frac{-3,15}{\left\{\frac{-8,55}{-8,16}\right\}} ; \quad H_{D}=\frac{-28,87}{\left\{\frac{-51,53}{-30,0}\right\}} ; \quad H_{C}=\frac{-38,52}{\left\{\frac{-24,00}{-37,22}\right\}} \quad[\mathrm{\kappa H}] .
\end{aligned}
$$

В подальшому визначаємо внутрішні зусилля в ребрі для небезпечного перерізу. В даному випадку їх два - на нижній опорі ребра, де діє максимальна стискуюча сила при нульовому моменті та переріз під термопідвіскою, де діє максимальний згинальний момент

$$
N_{\Sigma 1}=-86,0 \kappa \mathrm{H}, \quad M_{\Sigma 1}=0 ; \quad N_{\Sigma 2}=-35,6 \kappa \mathrm{H}, \quad M_{\Sigma 2}=38,0 \kappa \mathrm{Hм} .
$$

Для зусиль верхнього та нижнього поясу можна записати

$$
\begin{gathered}
N_{f t, 1}=N_{\Sigma 1}\left(1-y_{f} / h_{f}\right) \approx-57,4 \kappa \mathrm{H}, \quad N_{f t, 2}=N_{\Sigma 2}\left(1-y_{f} / h_{f}\right)-M_{\Sigma 2} / h_{f} \approx-78,0 \kappa \mathrm{H} ; \\
N_{b t, 2}=N_{\Sigma 2} y_{f} / h_{f}+M_{\Sigma 2} / h_{f} \approx 42,5 \kappa \mathrm{H} .
\end{gathered}
$$

В подальшому перевірка несучої здатності виконується відповідно до [12].

Висновок. Наведене дослідження, щодо розрахунку головного радіального ребра конічної покрівлі, виконаного у вигляді ферми з паралельними поясами, ілюструє простоту та універсальність запропонованої аналітичної методики оцінки параметрів напруженодеформованого стану конструкцій покрівель сталевих силосних ємностей.

\section{Література}

1. Баженов В.А. Будівельна механіка і теорія споруд. Нариси з історії / В.А. Баженов, Ю.В. Ворона, А.В. Перельмутер. - К. : Каравела, 2016. - 428 с.

2. Рабинович И.М. Основы строительной механики стержневых систем / И.М. Рабинович. - М.: Стройиздат, 1960. - 516 с.

3. Липницкий М.Е. Купола. Расчет и проектирование / М.Е. Липницкий. - Ленинград : Издательство литературы по строительству, 1973. - 129 с.

4. Chen X. Finite Element Modeling and Simulation with ANSYS Workbench / X. Chen, Y. Liu. - CRC Press, 2018. - 457 p.

5. Семёнов А.А. Металлические конструкции. Расчёт элементов и соединений с использованием программного комплекса SCAD / A.А. Семёнов, А.И. Габитов, И.А. Порываев, М. Н. Сафиуллин, В.В. Юрченко. - М. : СКАД СОФТ, АСВ, 2012. - 338 с.

6. ЛИРА-САПР. Книга I. Основы / Е.Б. Стрелец-Стрелецкий, А.В. Журавлев, P.Ю. Водопьянов; под ред. А.С. Городецкого. - К. : LIRALAND, 2019.- 154 с.

7. Семко В.О. Сталеві холодноформовані тонкостінні конструкції. Монографія / В.О. Семко. - Полтава : АCMI, 2017. - 325 с.

8. Рыбаков В.А. Основы строительной механики легких стальных тонкостенных конструкций. Учебное пособие / В.А. Рыбаков. - СПб. : Издательство ПУ, 2011. - 207 с.

9. Махінько Н.О. Геометричні характеристики перерізів тонкостінних елементів силосних ємностей в задачах розрахунку надійності / Н.О. Махінько // Вісник Одеської державної академії будівництва та архітектури. - Одеса : ОДАБА, 2019. - Вип. 74. - С.40-46.

10. Лапенко O.I. Розрахунок покрівель силосних ємностей великих діаметрів / O.I. Лапенко, Н.О. Махінько // Збірник наукових праць Українського інституту сталевих конструкцій ім. В.М. Шимановського. - К., 2019. - Вип. 21-22. - С. 67-77. 
11. Махінько Н.О. Розрахунок напружено-деформованого стану конусних покрівель при симетричному навантаженні / Н.О. Махінько // Вісник Придніпровської державної академії будівництва та архітектури. - Дніпро : ПДАБА, 2018. - Вип.1. - С.74-83.

12. ДБН В.2.6-198:2014. Сталеві конструкції. Норми проектування. - [Чинний від 201501-01]. - К. : Мінрегіон України, 2014. - 199 с. - (Державні будівельні норми України).

\title{
References
}

[1] V.A. Bazhenov, Budivelna mekhanika i teoriia sporud. Narysy z istorii. Kyiv: Karavela, 2016. [2] I.M. Rabinovich, Osnovy stroitelnoi mekhaniki sterzhnevykh sistem. Moscow: Stroiizdat, 1960. [3] M.E. Lipnitskii, Kupola. Raschet $i$ proektirovanie. Leningrad: Izdatelstvo literatury po stroitelstvu, 1973.

[4] X. Chen and Y. Liu, Finite Element Modeling and Simulation with ANSYS Workbench. CRC Press, 2018.

[5] A.A Semenov, A.I. Gabitov, I.A. Poryvaev, M.N. Safiullin and V.V. Iurchenko, Metallicheskie konstruktsii. raschet elementov $i$ soedinenii $s$ ispolzovaniem programmnogo kompleksa SCAD. Moscow: SKAD SOFT, ASV, 2012.

[6] E.B. Strelets-streletskii, A.V. Zhuravlev and R.IU. Vodopianov, LIRA-SAPR. Kniga i. osnovy. Kyiv: LIRALAND, 2019.

[7] V.O. Semko, Stalevi kholodnoformovani tonkostinni konstruktsii. Poltava: ASMI, 2017.

[8] V.A. Rybakov, Osnovy stroitelnoi mekhaniki legkikh stalnykh tonkostennykh konstruktsii. SanktPeterburg: Izdatelstvo Politekhnicheskogo universiteta, 2011.

[9] N.O. Makhinko, "Heometrychni kharakterystyky pereriziv tonkostinnykh elementiv sylosnykh yemnostei v zadachakh rozrakhunku nadiinosti," in Visnyk ODABA, Vol. 74.Odesa: ODABA, 2019, pp. 40-46.

[10] O.I. Lapenko and N.O. Makhinko, "Rozrakhunok pokrivel sylosnykh yemnostei velykykh diametriv" in Zb. nauk. pr. Ukrainskoho instytutu stalevykh konstruktsii im. V.M. Shymanovskoho, Vol. 21-22. Kyiv: Stal, 2019, pp. 67-77.

[11] N.O. Makhinko, "Rozrakhunok napruzheno-deformovanoho stanu konusnykh pokrivel pry symetrychnomu navantazhenni," in Visnyk PDABA, Vol. 1. Dnipro: PDABA, 2018, pp. 74-83.

[12] DBN V.2.6-198:2014. Stalevi konstruktsii. Normy proektuvannia. Kyiv: Minrehion Ukrainy, 2014.

\section{ПРАКТИЧЕСКИЕ ПОДХОДЫ К РАСЧЕТУ КОНИЧЕСКИХ КРОВЕЛЬ СТАЛЬНЫХ СИЛОСНЫХ ЕМКОСТЕЙ}

\author{
Махинько А.В., Д.т.н., с.н.с. \\ ТОВ «Этуаль» \\ pasargada1981@gmail.com, ORCID 0000-0002-9147-7087 \\ Махинько Н.А., к.т.н. \\ Национальный авиационный университет \\ pasargada1985@gmail.com, ORCID 0000-0001-8120-6374
}

\begin{abstract}
Аннотация. Данная статья касается вопросов изучения напряженно-деформируемого состояния тонколистовых стальных элементов конических покрытий цилиндрических силосов. Современные проектно-расчетные комплексы прочностного анализа, на основе метода конечных элементов, позволяют достаточно легко и с высокой точностью выполнять такой расчет. Однако в некоторых случаях возникают задачи, когда использование компьютеризированного аппарата ввода данных, наоборот усложняет процесс решения. Альтернативным является решение такой задачи в простой форме аналитического расчета. Его результат, хотя и будет иметь меньшую точность, однако значительно уменьшит как временные, так и трудовые затраты инженера. В данной статье рассмотрен ряд практических вопросов, которые возникают, в случае конструктивного решения главного радиального
\end{abstract}


ребра кровли в виде балки тонкостенного профиля или фермы с параллельными поясами. Проиллюстрированы особенности учета в расчетной схеме ребра присутствия кольцевых ребер жесткости, а также предложена упрощенная процедура оценки действующих нагрузок, которая заключается в использовании эквивалентной нагрузки с определенными параметрами. Поиск неизвестных внутренних усилий в данной расчетной схеме выполняется методом сил. Общий алгоритм заключается в последовательном определении усилий в главном радиальном ребре от единичных сил; вычислении параметров эквивалентного распределенной нагрузки; нахождении функций усилий от данной нагрузки и термоподвесок, а также от давления кольцевых ребер жесткости; определении горизонтальных перемещений точек отброшенных связей в основной системе и величины перемещений; расчете неизвестных опорных реакций и определении внутренних усилий для опасных сечений. Численная реализация позволяет выполнить оценку точности данного расчета и свидетельствует о простоте его выполнения, в сравнении с компьютерной процедурой расчета на основе метода конечных элементов.

Ключевые слова: силос, коническая кровля, главное радиальное ребро, опорная обечайка, кольца жесткости, напряженно-деформированное состояние.

\title{
PRACTICAL APPROACHES TO CALCULATION OF CONICAL ROOFS OF STEEL SILO CAPACITIES
}

\author{
Makhinko A.V., Doctor of Engineering., Senior Scientist, \\ ETUAL LLC, \\ pasargada1981@gmail.com, ORCID 0000-0002-9147-7087 \\ Makhinko N.O., PhD, Assistant Proffesor, \\ National Aviation University \\ pasargada1985@gmail.com, ORCID 0000-0001-8120-6374
}

\begin{abstract}
This article deals with the study of parameters of the stress-strain state of the elements of conical roofs of the cylindrical silos. They are mainly made of the thin sheet steel structures. On the basis of the finite element method modern design and calculation complexes of the strength analysis allow easily and with sufficient accuracy perform such a calculation. However, in some cases there are such problems when using a computerized data-entry machine rather complicates the decision process. The alternative is to solve this problem in a simple form of analytical calculation. Though the result will have less accuracy, but it will significantly reduce both time and work load of a designer. This article considers a number of practical questions that occur in case of a constructive solution of the main radial rib of the roof in the form of a beam of the thinwalled profile or a construction with parallel belts. In the calculation scheme of the rib it was illustrated the features of considering the presence of three annular stiffeners and secondary beams. It was proposed a simplified procedure for estimating current loads, by replacing four sections of unevenly distributed load with one of equivalent action. The search of unknown internal forces in this calculation scheme is performed by the force method. The general algorithm lies in a consistent determination of efforts in the main radial rib from the single efforts; in calculation of parameters of equivalently distributed load; in finding the effort functions of the given load and thermal suspension, as well as of the pressure of the annular stiffeners; in determining the horizontal displacements of points of disconnection in the main system and the magnitude of the displacements; in calculation of unknown support reactions and determination of internal efforts for dangerous sections. The numerical implementation allows estimating the accuracy of this calculation. Also the example demonstrates the simplicity of its implementation, compared to a computer procedure based on the finite element method.
\end{abstract}

Keywords. Silos, conical roof, the main radial rib, support shell ring, stiffening rings, stressstrain state. 


\title{
ВПЛИВ ПЕРІОДУ ЗАМИКАННЯ НА НАПРУЖЕНО-ДЕФОРМОВАНИЙ СТАН КОНСТРУКЦІЙ СТАЛЕВИХ КАРКАСІВ ОДНОПОВЕРХОВИХ БУ ДІВЕЛЬ
}

\author{
Пушкар Н.В., к.т.н., доцент \\ Одеська державна академія будівниитва і архітектури \\ PushkarN@ukr.net, ORCID: 0000-0002-4243-7353
}

Анотація. Проведений чисельний експеримент, в якому змодельовані та розраховані сталеві каркаси однопролітних одноповерхових будівель при шарнірному та жорсткому 3'єднанні колон 3 фундаментами. Досліджений вплив способу з'єднання колон 3 фундаментами, температури атмосферного повітря та періоду замикання сталевих каркасів на напружено-деформований стан несучих конструкцій. Проаналізовані згинальні моменти i найбільші напруження в конструкціях. Показано, що вибір періоду замикання сталевого каркасу з урахуванням розрахункової схеми може служити засобом управління напруженодеформованим станом несучих конструкцій.

Ключові слова: сталевий каркас, ригель, колона, температурні впливи, період замикання.

Вступ. Зміни температури атмосферного повітря викликають додаткові переміщення в незамкнутих статично визначених конструкціях, а також в елементах замкнутих статично невизначених конструкцій, які не мають повної свободи переміщень. У найпростіших випадках повної можливості або повної відсутності свободи переміщень стержнів температурні переміщення i напруження можна визначити 3 урахуванням коефіцієнта лінійного розширення та модуля пружності матеріалу. Такі розрахунки для сталевих елементів показують, що у вільних стержнях від дії температури виникають переміщення, що викликають помітні зміни геометричної схеми конструкції, а в затиснених стержнях виникають напруження, які сягають до третини розрахункового опору сталі. Отже, зміни температури в обох випадках істотно впливають на напружено-деформований стан сталевих стержнів.

Розрахунок несучих сталевих конструкцій на дію температури повітря виконується 3 урахуванням температурних перепадів, які встановлені Державними будівельними нормами України [1]. Час замикання каркасу (зима чи літо) в завершену статично невизначену систему також може впливати на внутрішні зусилля в конструкціях, а отже, і на сумарний напружено-деформований стан будівлі.

Аналіз останніх джерел досліджень і публікацій, постановка проблеми. Загальні методи розрахунків несучих конструкцій на зміни температури розроблені в будівельній механіці [2], виконання таких розрахунків плоских і просторових конструкцій різного виду можливе в поширених програмних комплексах. Державними будівельними нормами України [1] встановлені розрахункові значення перепадів температури несучих конструкцій 3 урахуванням умов їх експлуатації та періоду замикання. Очевидно, що від'ємний температурний перепад при замиканні системи влітку і додатній - при замиканні взимку будуть викликати внутрішні зусилля протилежних знаків, але дослідження впливу цього явища на напружено-деформований стан несучих конструкцій сталевих каркасів реальних будівель в літературі не виявлено.

Мета та завдання. Метою даної роботи є дослідження впливу часу замикання на величину внутрішніх зусиль в несучих конструкціях сталевих каркасів одноповерхових будівель та можливості управління напружено-деформованим станом цих конструкцій шляхом вибору оптимального періоду замикання.

Матеріали та методика дослідження базуються на проведенні чисельного експерименту, в якому сталевий каркас одноповерхової будівлі змодельований як єдина 
просторова система, з визначенням внутрішніх зусиль і напружень в окремих конструкціях від дії постійних та змінних навантажень, включаючи перепади температури. Для чисельного експерименту обрано програмний комплекс Autodesk Robot Structural Analysis [3], перевагами якого, у порівнянні з програмними комплексами ЛIPA-CAПР, SCAD та ANSYS, $\epsilon$ більш зручний інтерфейс при генеруванні розрахункової схеми.

Для дослідження обрана конструктивна схема, яка досить широко застосовується при спорудженні виробничих будівель. В якості базового модуля сталевого каркасу прийнята однопролітна рама, схеми якої та характерні перерізи, в яких визначатимуться внутрішні зусилля, зображені на рис.1. У даному чисельному експерименті прийнято, що ригелі 3 колонами з'єднані жорстко, а приєднання колон до фундаментів може бути жорстким або шарнірним. Прийнятий проліт будівлі - 24 м, висота до карнизного вузла -8 м, висота конькового вузла -11 м, ухил покрівлі $-14^{\circ}$.

Каркаси створювалися шляхом нарощування необхідного числа поперечних рам 3 кроком 12 м. Рами об'єднані прогонами покрівлі та системою в'язей по колонах і ригелях згідно з вимогами ДБН [4]. Матеріал конструкцій -сталь С245, ригелі прийняті з прокатних двотаврів балочного профілю, колони - 3 прокатних двотаврів 3 широкими поличками. Поперечні перерізи ригелів та колон підбиралися в процесі розрахунку за критерієм міцності, що виправдано великими значеннями згинальних моментів.

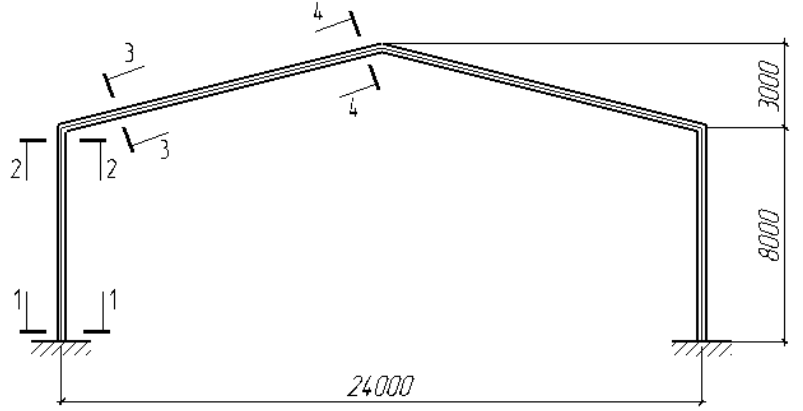

a

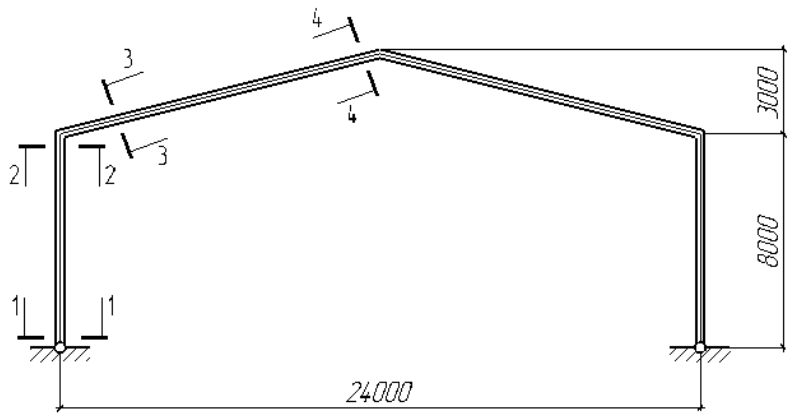

6

Рис. 1. Конструктивні схеми однопролітної поперечної рами:

a - жорстке з'єднання колон з фундаментами; б - шарнірне з'єднання колон з фундаментами.

Загалом був змодельований каркас, складений з рам, зображених на рис.1, розмірами $24 \times 108$ м (один проліт, 9 кроків). Даний каркас $є$ характерним для порівняно невеликих виробничих будівель масового застосування. Каркас моделювався та розраховувався в шести варіантах:

- шарнірно обперті колони, без урахування температурних впливів;

- шарнірно обперті колони, замикання відбулося влітку;

- шарнірно обперті колони, замикання відбулося взимку;

- жорстко обперті колони, без урахування температурних впливів;

- жорстко обперті колони, замикання відбулося влітку;

- жорстко обперті колони, замикання відбулося взимку.

Каркас розраховувався на навантаження від власної ваги несучих та огороджувальних конструкцій, а також на снігове та вітрове навантаження за ДБН [1] для м. Полтави, які наближаються до середніх по території України. Температурні впливи визначені за ДБН [1] як для несучих конструкцій неопалюваної будівлі. Граничне розрахункове значення перепаду температури конструкцій дорівнює $-39^{\circ} \mathrm{C}$ при замиканні влітку та $+31^{\circ} \mathrm{C}-$ при замиканні взимку.

За результатами розрахунків на окремі навантаження складалися три розрахункові комбінації зусиль: постійне та змінні навантаження без урахування впливу температури; постійне та змінні навантаження 3 урахуванням температурного впливу при літньому замиканні каркасу; постійне та змінні навантаження з урахуванням температурного впливу при зимовому замиканні каркасу. Після виконання статичного розрахунку засобами 
програмного комплексу обчислювалися напруження в характерних перерізах колон і ригелів (рис.1), та вибиралися максимальні значення напружень в основних несучих елементах. При необхідності перерізи елементів коригувалися таким чином, щоб вони були мінімально можливими в межах сортаменту прокатних двотаврів.

Для кожної з вказаних вище груп елементів вибиралися такі контрольні параметри: найбільші значення згинальних моментів в площині рами $\left(\mathrm{M}_{\mathrm{Y}}\right)$, 3 площини рами $\left(\mathrm{M}_{\mathrm{Z}}\right)$ та найбільші напруження по групі конструкцій ( $\left.\sigma_{\max }\right)$. За обраними контрольними параметрами аналізувалися розподіли розрахункових зусиль та перерізів ригелів, колон, а також їх зміни залежно від величини температурних впливів при різних періодах замикання каркасу.

Результати досліджень. Отримані результати чисельного експерименту стосовно напружено-деформованого стану каркасів представлені в табл.1, яка містить позначення перерізів ригелів та колон, номери підібраних двотаврів, а також перераховані вище контрольні параметри.

Таблиця 1 - Результати розрахунків елементів каркасу

\begin{tabular}{|c|c|c|c|c|c|c|c|}
\hline \multirow{2}{*}{$\begin{array}{c}\text { Несуча } \\
\text { конструкція }\end{array}$} & \multirow{2}{*}{$\frac{\frac{m}{2}}{\frac{0}{0}}$} & \multicolumn{3}{|c|}{$\begin{array}{c}\text { Жорстке закріплення: } \\
\text { ригель 70Б2, колона 60Ш2 }\end{array}$} & \multicolumn{3}{|c|}{$\begin{array}{c}\text { Шарнірне закріплення: } \\
\text { ригель } 80 Б 1, \text { колона 60Ш2 }\end{array}$} \\
\hline & & $\begin{array}{l}\sigma_{\max } \\
\mathrm{M} \Pi \mathrm{a}\end{array}$ & $\underset{\kappa \mathrm{M} \times \mathrm{M}}{\mathrm{M}_{\mathrm{Y}}}$ & $\begin{array}{c}\mathrm{M}_{\mathrm{Z}} \\
\kappa \mathrm{H} \times \mathrm{M}\end{array}$ & $\begin{array}{l}\sigma_{\max } \\
\mathrm{M \Pi a}\end{array}$ & $\underset{\kappa \mathrm{M} \times \mathrm{M}}{\mathrm{M}_{\mathrm{Y}}}$ & $\begin{array}{c}\mathrm{M}_{\mathrm{Z}} \\
\kappa \mathrm{H} \times \mathrm{M}\end{array}$ \\
\hline \multicolumn{8}{|c|}{ Без урахування впливу температури } \\
\hline \multirow{2}{*}{ Колона } & 1 & 177 & $-714,5$ & 1,9 & 15 & 0 & 0 \\
\hline & 2 & 215 & 880,7 & $-3,0$ & 232 & 948,5 & $-4,0$ \\
\hline \multirow{2}{*}{ Ригель } & 3 & 228 & $-885,7$ & 0,7 & 200 & $-954,0$ & 0,9 \\
\hline & 4 & 141 & 417,5 & $-12,8$ & 169 & 659,3 & $-14,4$ \\
\hline \multicolumn{8}{|c|}{ При замиканні влітку } \\
\hline \multirow{2}{*}{ Колона } & 1 & 186 & $-661,7$ & $-16,3$ & 15 & 0 & 0 \\
\hline & 2 & 215 & 877,5 & $-3,7$ & 229 & 937,3 & $-3,7$ \\
\hline \multirow{2}{*}{ Ригель } & 3 & 227 & $-882,6$ & 0,9 & 198 & $-942,8$ & 0,9 \\
\hline & 4 & 141 & 449,9 & $-9,7$ & 169 & 679,6 & $-12,4$ \\
\hline \multicolumn{8}{|c|}{ При замиканні взимку } \\
\hline \multirow{2}{*}{ Колона } & 1 & 207 & $-756,5$ & 16,5 & 15 & 0 & 0 \\
\hline & 2 & 214 & 883,2 & $-2,4$ & 234 & 957,4 & $-4,2$ \\
\hline \multirow{2}{*}{ Ригель } & 3 & 228 & $-888,2$ & 0,6 & 202 & $-962,9$ & 1,0 \\
\hline & 4 & 142 & 391,7 & $-15,3$ & 170 & 643,1 & $-16,0$ \\
\hline
\end{tabular}

Аналіз отриманих результатів показав, що і при шарнірному, і при жорсткому закріпленні в фундаментах переріз колони визначається згинальними моментами в карнизному вузлі рами, переріз ригеля визначається опорним згинальним моментом в карнизному вузлі рами. Момент посередині прольоту ригеля приблизно у 1,5 рази менший від опорного моменту при шарнірному обпиранні колон і майже в 2 рази - при жорсткому.

Заміна шарнірного закріплення колони в фундаменті на жорстке приводить до зменшення згинальних моментів у карнизному вузлі рами на $7 \ldots 10 \%$ і при літньому, і при зимовому періодах замикання. При цьому поперечний переріз ригеля також зменшується на $10 \%$, переріз колони в межах існуючого сортаменту не змінюється, але найбільші згинальні напруження в ній зменшуються на $7 \ldots 10 \%$. 
При замиканні розглянутого каркасу з шарнірним обпиранням колон у літній період зміни температури зменшують напруження у перерізах 2-2, 3-3 (рис.1) до 1,3\%, на перерізи 1-1, 4-4 - не впливають. При замиканні взимку - підвищують в усіх перерізах до 1\%, окрім перерізу 1-1. При замиканні каркасу з жорстким обпиранням колон влітку зміни температури збільшують напруження у перерізі 1-1 на 5\%, в інших перерізах - майже не впливають. При замиканні взимку - підвищують у перерізі 1-1 на 17\%, в інших перерізах також майже не впливають.

\section{Висновки:}

1. Запропонована методика моделювання каркасів дозволила проаналізувати вплив способу з'єднання колон з фундаментами, температури повітря та періоду замикання на напружено-деформований стан несучих конструкцій сталевих каркасів однопролітних одноповерхових будівель.

2. Максимальні напруження від впливу температури повітря у каркасі з шарнірним обпиранням колон не перевищують $1,3 \%$ напружень, викликаних сумарною дією усіх інших навантажень, незалежно від часу замикання, що свідчить про незначний вплив перепадів температури при невеликих розмірах каркасу в плані і шарнірному типі обпирання колон на фундаменти.

3. При жорсткому обпиранні колон на фундаменти температурна повітря впливає на напруження у більшому ступені, збільшуючи їх до 5\% при літньому замиканні, до 17\% - при зимовому замиканні каркасу, при тих самих його розмірах.

4. Обираючи період замикання сталевого каркасу, у відповідності до розрахункової схеми, можна управляти зусиллями та забезпечувати економію сталі при проектуванні будівель.

5. Вплив температури повітря та періоду замикання сталевих каркасів на напруженодеформований стан несучих конструкцій потребує подальших досліджень при розмірах будівель, більших за розглянуті в даній роботі, особливо, при жорсткому типі обпирання колон на фундаменти.

\section{Література}

1. ДБН В.1.2-2:2006. Система забезпечення надійності та безпеки будівельних об'єктів. Навантаження і впливи. Норми проектування. - К.: Мінбуд України, 2007. - 60 с.

2. Строительная механика. Под ред. Ю.И. Бутенко. - Киев: Вища школа. Головное издBo, 1989. -488 c.

3. Autodesk Robot Structural Analysis Professional 2012. [Електронний ресурс]. Режим доступу: http://docs.autodesk.com/RSA/2012/RUS/landing.html.

4. ДБН В.2.6-163:2010. Конструкції будівель і споруд. Сталеві конструкції. Норми проектування, виготовлення і монтажу. - К.: Мінрегіонбуд України, 2010. - 220 с.

\section{References}

[1] DBN V.1.2-2:2006. Systema zabezpechennja nadijnosti ta bezpeky budiveljnykh ob'jektiv. Navantazhennja i vplyvy. Normy proektuvannja. - K.: Minbud Ukrajiny, 2007. - 60 p.

[2] Stroitel'naja mehanika. Pod red. Ju.I. Butenko. - Kiev: Vishha shkola. Golovnoe izd-vo, 1989. $488 \mathrm{p}$.

[3] Autodesk Robot Structural Analysis Professional 2012. [Elektronnyj resurs]. Rezhym dostupu: http://docs.autodesk.com/RSA/2012/RUS/landing.html.

[4] DBN V.2.6-163:2010. Konstrukciji budivelj i sporud. Stalevi konstrukciji. Normy proektuvannja, vyghotovlennja i montazhu. - K.: Minreghionbud Ukrajiny, 2010. - 220 p. 


\title{
ВЛИЯНИЕ ПЕРИОДА ЗАМЫКАНИЯ НА НАПРЯЖЁННО-ДЕФОРМИРОВАННОЕ СОСТОЯНИЕ КОНСТРУКЦИЙ СТАЛЬНЫХ КАРКАСОВ ОДНОЭТАЖНЫХ ЗДАНИЙ
}

\author{
Пушкарь Н.В., к.т.Н., доцент \\ Одесская государственная академия строительства и архитектуры \\ PushkarN@ukr.net, ORCID: 0000-0002-4243-7353
}

Аннотация. Изменения температуры атмосферного воздуха вызывают дополнительные перемещения в незамкнутых статически определимых конструкциях, а также в элементах замкнутых статически неопределимых конструкций, не имеющих полной свободы перемещений. Расчеты стальных элементов на температурные перемещения с помощью коэффициента линейного расширения и модуля упругости материала показывают, что в свободных стержнях от действия температуры возникают перемещения, вызывающие заметные изменения геометрической схемы конструкции, а в защемлённых стержнях возникают напряжения, величина которых доходит до трети расчетного сопротивления стали. То есть изменения температуры в обоих случаях существенно влияют на напряжённодеформированное состояние стальных стержней. Расчет несущих стальных конструкций на действие температуры воздуха выполняется с учетом температурных перепадов, установленных Государственными строительными нормами Украины. Время замыкания каркаса (зима или лето) в завершенную статически неопредимую систему также может влиять на внутренние усилия в конструкциях, а, следовательно, и на суммарное напряжённодеформированное состояние здания, однако исследования влияния этого явления на стальные каркасы реальных зданий в литературе отсутствуют. Поэтому целью данной работы является исследование влияния времени замыкания на величину внутренних усилий в несущих конструкциях стальных каркасов одноэтажных зданий.

В работе представлен численный эксперимент, в котором смоделированы и рассчитаны стальные каркасы однопролетных одноэтажных зданий размерами $24 \times 108$ м при шарнирном и жестком соединении колонн с фундаментами. Каркасы моделировались в программном комплексе Autodesk Robot Structural Analysis c определением внутренних усилий и напряжений в отдельных конструкциях от действия постоянных и переменных нагрузок, включая перепады температуры. По результатам расчётов на отдельные нагрузки составлялись три расчетные комбинации усилий: постоянные и переменные нагрузки без учёта влияния температуры; постоянные и переменные нагрузки с учётом температурного воздействия при летнем замыкании каркаса; постоянные и переменные нагрузки с учётом температурного воздействия при зимнем замыкании каркаса. Для дальнейшего анализа выбирались следующие контрольные параметры: наибольшие значения изгибающих моментов в плоскости рамы, из плоскости рамы и наибольшие напряжения по группе конструкций.

Анализ полученных результатов показал, что и при шарнирном, и при жёстком закреплении в фундаментах сечение колонны определяется изгибающим моментом в карнизном узле рамы, сечение ригеля - опорным изгибающим моментом в карнизном узле рамы. Момент посередине пролета ригеля примерно в 1,5 раза меньше опорного момента при шарнирном опирании колонн и почти в 2 раза - при жёстком. Максимальные напряжения от воздействия температуры воздуха в каркасе с шарнирным опиранием колонн не превышают 1,3\% напряжений, вызванных суммарным действием всех нагрузок, независимо от времени замыкания, что свидетельствует о незначительном влиянии перепадов температуры при небольших размерах каркаса в плане и шарнирном типе опирания колонн на фундаменты. При жестком опирании колонн на фундаменты температура воздуха влияет на напряжения в большей степени, увеличивая их до 5\% при летнем замыкании и до 17\% - при зимнем замыкании каркаса, при тех же его размерах в плане. Следовательно, выбор периода замыкания стального каркаса с учётом расчётной 
схемы может служить средством управления напряжённо-деформированным состоянием несущих конструкций каркаса.

Ключевые слова: стальной каркас, ригель, колонна, температурные воздействия, период замыкания.

\title{
THE INFLUENCE OF THE LOCK PERIOD ON THE STRESS-STRAIN STATE OF THE BEARING STRUCTURES OF ONE-STOREY BUILDINGS STEEL FRAMES
}

\author{
Pushkar N.V., Ph.D., Associate Professor \\ Odessa State Academy of Civil Engineering and Architecture \\ PushkarN@ukr.net, ORCID: 0000-0002-4243-7353
}

\begin{abstract}
The changes in air temperature cause additional movement in open statically determinate structures, as well as in elements of closed statically indefinable structures that don't have a complete freedom of movement. Mathematical calculations of steel elements on the temperature displacements show that displacements which occur in free rods due to the action of temperature cause noticeable changes in the geometric scheme of construction. And in the pinched rods, stresses arise, the value of which reaches one third of the steel resistance. That is, the temperature changes in both cases significantly affect on the stress-strain state of steel rods. The frame locking period (winter or summer) in a complete statically indefinable system can also affect the internal forces in structures and on the total stress-strain state of the building. However, there is no study of the effect of this phenomenon on steel frames of real buildings in the literature. Therefore, the aim of this work is study the effect of locking period on the internal forces in the load-bearing structures of one-story buildings steel frames.

A numerical experiment in which steel frames of one-span one-story buildings with dimensions of $24 \times 108 \mathrm{~m}$ are simulated and calculated, in which the columns with the foundations are articulated and rigidly connected is presented. Frames were modeled in the software package Autodesk Robot Structural Analysis with the determination of internal forces and stresses in individual structures from the action of constant and variable loads, including temperature differences. Based on the results of calculations for individual loads, three design combinations of efforts were compiled: constant and variable loads without taking into account the influence of temperature; constant and variable loads, taking into account the temperature effects during summer frame locking period; constant and variable loads, taking into account the temperature effects during winter frame locking period. For further analysis, the following control parameters were selected: the greatest values of bending moments in the plane of the frame, from the plane of the frame and the greatest stresses in the group of structures.

An analysis of the results showed that both with articulated and rigid fastening in the foundations, the cross section of the column is determined by the bending moment in the cornice of the frame. The cross-section of the beam is determined by the reference bending moment in the cornice of the frame. The moment in the middle of the span of the beam is approximately 1,5 times less than the reference moment when the columns are hinged and almost 2 times less with a rigid support of the columns. The maximum stresses from the influence of air temperature in the frame with the hinged support of the columns don't exceed $1,3 \%$ of the stresses caused by the total effect of all loads, regardless of the locking period. This indicates an insignificant effect of temperature differences with small sizes of the frame in plan and the hinged type of support of the columns on the foundations. When the columns are rigidly supported on the foundations, the air temperature affects stresses to a greater extent, increasing them to $5 \%$ during summer locking period and up to $17 \%$ during winter locking period. Therefore, the choice of the period of locking period of the steel frame, taking into account the design scheme, can serve as a means of controlling the stress-strain state of the supporting structures of the frame.
\end{abstract}

Keywords: steel frame, beam, column, temperature influences, locking period. 


\title{
УСИЛЕНИЕ СУЩЕСТВУЮЩЕЙ НЕСУЩЕЙ КОНСТРУКЦИИ ПОКРЫТИЯ
}

\author{
Романенко С.Н., старший преподаватель \\ romanesko666@gmail.com, ORCID: 0000-0002-0443-3896
}

Андриевская Я.П., ассистент ГВУЗ «Херсонский государственный аграрный университет» yanaandrievska321@gmail.com, ORCID:0000-0003-3052-2515

\begin{abstract}
Аннотация. В статье приведены результаты обследования здания для выявления поврежденных, деформированных несущих элементов каркаса. Разработаны мероприятия по усилению элементов фермы с целью дальнейшей безопасной эксплуатации, а также изменены условия работы конструкции, в результате роста нагрузки не предусмотренных проектом (крепление солнечных панелей). Разработана расчетная модель металлической фермы, усиленной введением новых дополнительных элементов решетки - шпренгелей. После обследования и проверочных расчетов принято решение, что эксплуатация здания после установки на крыше элементов альтернативной энергии возможна при условии разработки специального проекта на усиление элементов металлической фермы.
\end{abstract}

Ключевые слова: ферма, усиление, шпренгель, нагрузки, перемещения, прогиб.

Вступление. Стремительное подорожание энергоносителей в мире (природного газа, угля, нефти и т.д.) приводит к чрезвычайно стремительному росту цен на электрическую энергию для украинских предприятий и отдельных хозяйств.

На сегодняшний день есть эффективное решение для населения и производства по поводу внедрения систем генерации электроэнергии из альтернативных (возобновляемых) источников. Солнечные электростанции представлены в виде систем, что функционируют на основе солнечных батарей, которые создают электрическую энергию из солнечной. Установка солнечных электростанций на крыше зданий и сооружений ведет к росту нагрузки на несущие конструкции и к изменениям условий эксплуатации, что является основной причиной усиления конструкций.

Анализ последних исследований и публикаций. К наиболее распространенным традиционным способам усиления металлоконструкций относятся: увеличение и наращивание сечений элементов, устройство дополнительных связей, рёбер, диафрагм, распорок, усиления соединений элементов, установка дополнительных элементов в существующие конструкции.

Способы усиления ферм весьма разнообразны. Широко применяется традиционный, наиболее универсальный способ увеличение сечений стержней. Суть его заключается в присоединении дополнительных, стержневых элементов усиления к существующим стержням и включение их в общую работу по восприятию усилий, возникающих в элементах от внешних воздействий.

Усиление ферм посредством увеличения пространственной жесткости достигается путем постановки дополнительных связей, тяжей, увеличением сечения стержней.

Способом изменения конструктивной схемы можно усилить как отдельные стержни, так и ферму в целом. Усиление сжатых стержней ферм устройством шпренгелей, уменьшающие расчетную длину стержней. Такой метод усиления повышает устойчивость стержней только в плоскости фермы и его следует применять при незначительном увеличении усилий в стержнях.

Принципиально новым способом усиления металлических конструкций является способ, основанный на использовании армированных фибрами полимерных материалов. Усиление композитными материалами металлических конструкций, в отличие от железобетонных, получило наименьшее распространение. Внешнее армирование с фиброармированных пластиков в основном используется для усиления колонн, балок, 
стропильных и подстропильных ферм (элементы которые больше и чаще всего нуждаются в усилении) и других конструкций. Однако при проектировании усиления конструкций из металла необходимо учитывать остаточную несущую способность и жесткость элементов, которые поддаются усилению.

Цели и задания. Целью исследования является обследование здания для выявления поврежденных элементов, формулирование предложений по усилению или замене этих элементов, расчет их конструктивных параметров. Исследование выполнено с применением классических расчетов строительной механики и методов компьютерного моделирующего эксперимента в программном комплексе «Лира САПР 2013», который алгоритмически базируется на методе конечных элементов.

Задания исследования:

- разработка расчетной модели металлической фермы, усиленной дополнительными стержнями;

- расчет существующей и усиленной металлической фермы;

- проанализировать результаты, полученные после экспериментальных исследований.

Материалы и методика исследования. Для решения поставленных задач было выполнено комплексное обследование и обмеры строительных конструкций склада согласно нормам [1-4].

Объектом обследования являются строительные конструкции одноэтажного зернового склада № 6. Согласно технической документации зерновой склады № 6 построен 1955 году. Склад расположен в сельскохозяйственном комплексе ХПП ОАО «Херсонский КХП» по адресу: Херсонская обл., Белозерский район, с. Никольское, ул. Репринская, дом 2-А.

В плане здание прямоугольной формы с размерами 61,5 х 19,9 м. Конструктивная схема здания - каркасное. Основными элементами каркаса однопролетного здания являются металлические колонны и фермы ФС-1, которые образуют поперечную раму каркаса. Продольные элементы каркаса - это связи между колоннами и фермами, кровельные прогоны.

Фундаменты под наружные стены - ленточные из бутовой кладки.

Отдельно выполнены фундаменты под колонны, примыкающие к ленточному существующему фундаменту. Фундамент под металлические колонны столбчатый монолитный железобетонный. Глубина заложения фундамента 0,3 м от уровня чистого пола.

Наружные стены здания выполнены двухслойные с использованием кладки из силикатного кирпича снаружи и камня ракушечника внутри. Высота наружных стен составляет 3,5 м. По периметру стен выполнен монолитный железобетонный пояс высотой 0,4 м. Вдоль продольных стен снаружи установлено 22 контрфорсы с двух сторон здания.

Крыша - ломаная. Материал покрытия - профиль оцинкованный листовой гнутый с трапециевидными гофрами для строительства, высота волны 20 мм согласно ДСТУ Б 2.6-9: 2008.

Ферма ФС-1 металлическая треугольного очертания. Система решетки - треугольная с дополнительными стойками. Решетка фермы выполнена из стального гнутого замкнутого сварного профиля (ГСП) квадратного сечения, верхний и нижний пояс имеет швеллерное сечение - из двух швеллеров, установленных полками внутрь.

Прогоны покрытия выполнены сплошного сечения с ГСП квадратного сечения.

Колонны сплошного и постоянного по высоте сечения выполнены из стальной трубы радиусом 273 мм, закрепленные на опорной плите. Шаг колонн составляет 6,0 м. Соединение колонны с фундаментом жесткое с помощью анкерных болтов. Сопряжение колонны с фундаментом принято с помощью базы с траверсой.

Высота помещения зернового состава составляет 9,0 м.

В результате визуального и инструментального обследования строительных конструкций здания во время эксплуатации было установлено, что эксплуатируемые пролетные металлоконструкции (фермы) имеют сверхнормативные прогибы и требуют 
корректировки проектных решений. Провисание ферм предотвращает обустройство строительного подъема, который не был учтен при изготовлении (фото 1).

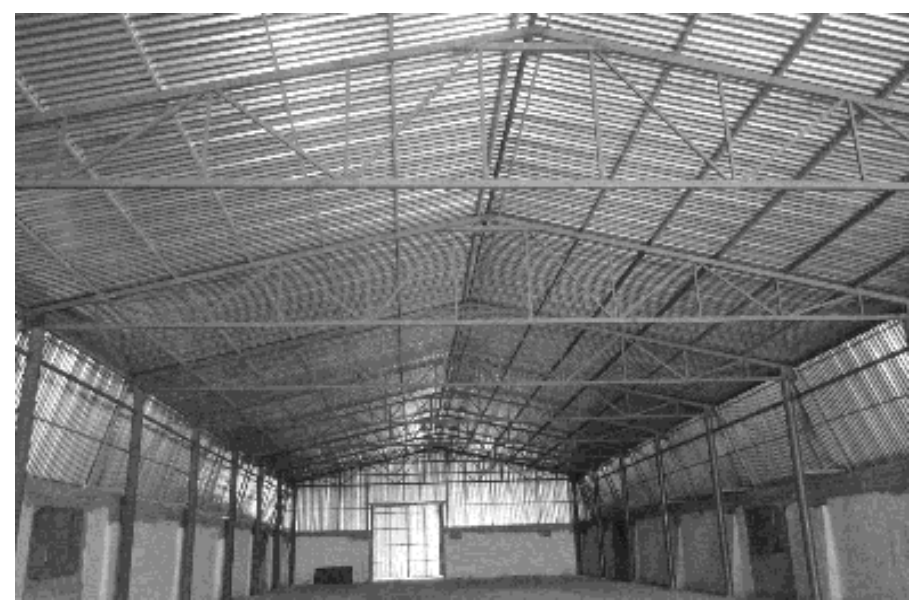

Фото 1. Общий вид каркаса склада. Стропильные фермы имеют сверхнормативные прогибы фермы.

Крепление прогонов к верхнему поясу выполнено с помощью сварки и не в узлах

После обследования принято решение о возможности использования существующих конструкций в дальнейшем. При этом конструкции могут быть усилены с восстановлением их работоспособности и повышение несущей способности за счет специальных мероприятий.

Основной причиной усиления фермы являются:

- изменение условий эксплуатации по сравнению с проектными;

- рост нагрузки не предусмотренных проектом (крепление солнечных батарей);

- наличие недопустимых дефектов и повреждений на стадии проектирования, изготовления и монтажа.

Предложено рациональный вариант усиления несущих конструкций покрытия. Это введение новых дополнительных элементов решетки - шпренгелей (см. рис.1).

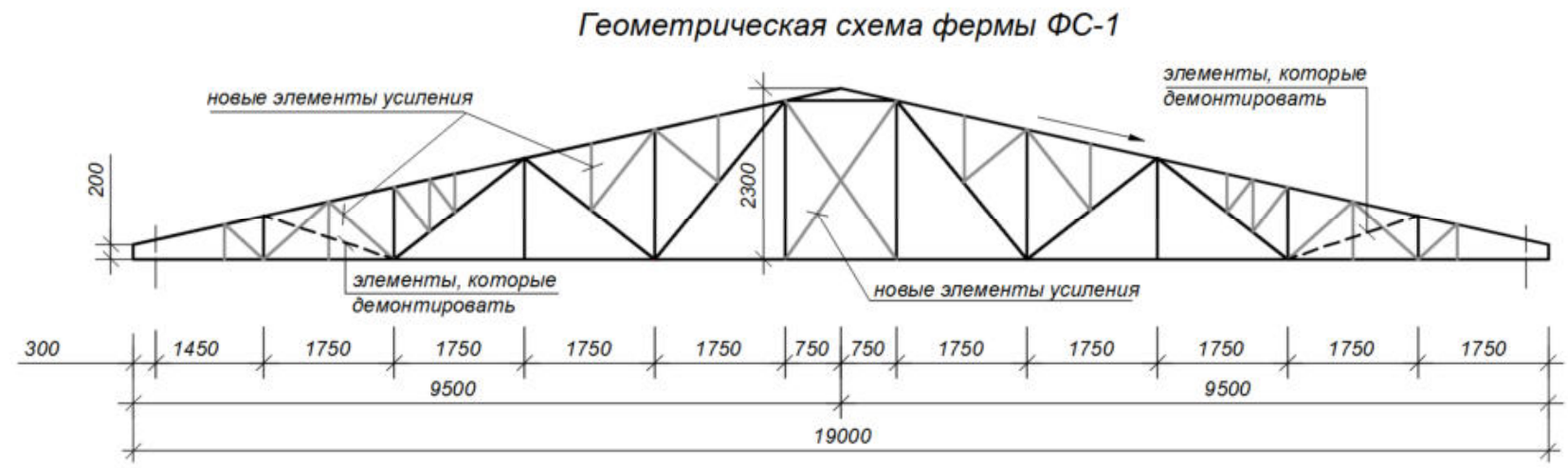

Рис. 1. Схема стропильной фермы ФС-1, усиленной с помощью дополнительных элементов решетки

Как правило, необходимым элементом обследования является проверочный расчет конструкций с учетом их фактического состояния. Проверочный расчет конструкций с учетом влияния дефектов и повреждений выполняется с целью определения несущей способности, а также разработки мероприятий по усилению элементов фермы для дальнейшей безопасной эксплуатации. 
Результаты исследований. Статический расчет конструкции выполнялся с учетом выявленного фактического состояния элементов и соединений. Для оценки несущей способности металлоконструкций каркаса здания склада №6 в сельскохозяйственном комплексе ХПП ОАО «Херсонский КХП» по адресу: Херсонская обл., Белозерский район, с. Никольское, ул. Репринская, дом 2-А. дом 2-А, согласно нормам [5, 6] выполнен расчет металлической фермы в программном комплексе «Лира САПР 2013», которая является компьютерной системой для структурного анализа и проектирования. [7]

Проверка несущей способности и устойчивости конструкций выполнена в соответствии с действующими нормативными документами ДБН 2.6-198: 2014 [8].

Расчет ферм выполняют в такой последовательности:

- разработка расчетной схемы фермы;

- определение и сбор нагрузки;

- определение расчетных усилий в элементах фермы;

- подбор поперечных сечений растянутых и сжатых элементов.

Было создано 2 расчетные модели: 1- расчет модели без усиления, 2 -расчет модели с усилением.

Расчет модели без усиления. Расчетная схема с приложенными нагрузками и перемещений вдоль оси $\mathrm{Z}$ от расчетных нагрузок представлена на рис. 2, 3.

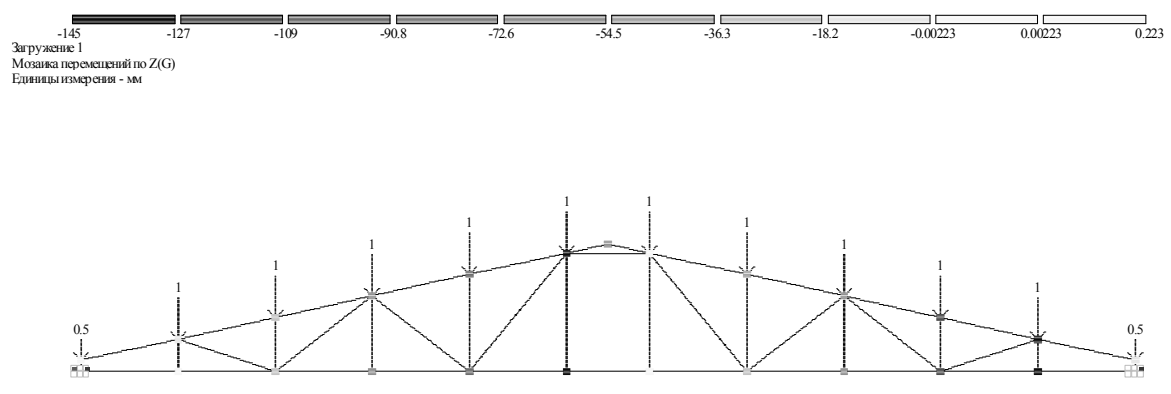

$\mathrm{z}_{\mathrm{Y}} \mathrm{x}$

Рис. 2. Перемещение вдоль оси $\mathrm{Z}$ от расчетных нагрузок в ферме без усиления
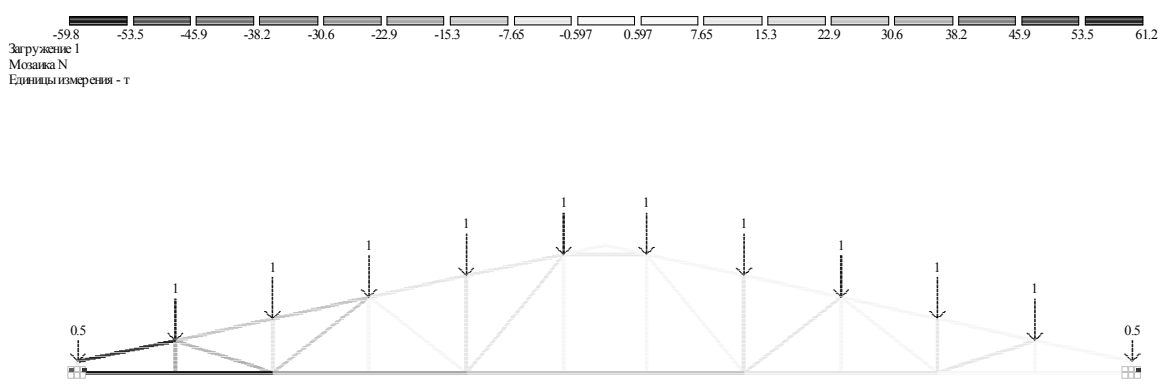

$\stackrel{z_{Y}}{h x}$

Рис. 3. Расчетные усилия от нормативных нагрузок в элементах фермы

Расчет модели с усилением. Разработана новая схема фермы с учетом нагрузки от устройства на крыше солнечных батарей. На рис. 4, 5 представлены расчетные схемы с приложенными нагрузками. 


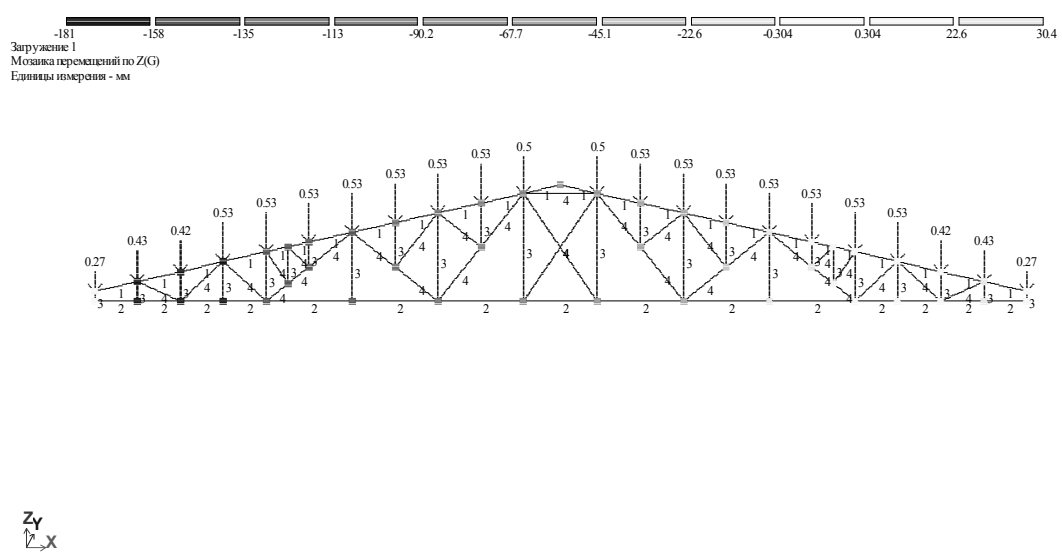

Рис. 4. Перемещение вдоль оси Z от расчетных нагрузок в усиленной ферме

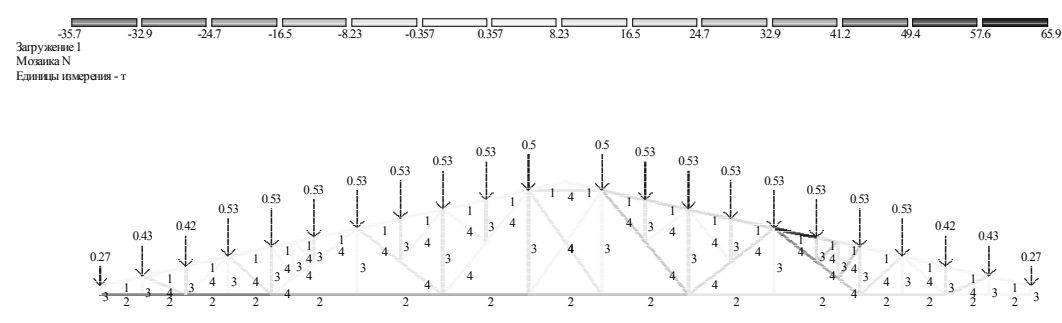

$z_{\mathrm{z}}$

Рис. 5. Расчетные усилия от нормативных нагрузок в элементах фермы

Выводы. В результате усиления произошло распределение усилий и изменился характер деформирования фермы, повысилась несущая способность.

После обследования и проверочных расчетов принято решение, что эксплуатация здания после установки на крыше элементов альтернативной энергии возможна при условии устранения выявленных недостатков и дефектов и разработки специального проекта на усиление элементов металлической фермы.

\section{Литература}

1. ДБН В.3.1-1-2002. Ремонт і підсилення несучих і огороджувальних будівельних конструкцій і основ промислових будинків та споруд. [Чинний з 2017-04-01]. Вид. офіц. Київ : ДП "УкрНДНЦ", 2017. 82 с.

2. ДСТУ-Н Б В.1.2-18:2016. Настанова щодо обстеження будівель і споруд для визначення та оцінки їх технічного стану. [Чинний $з$ 2017-04-01]. Вид. офіц. Київ : ДП "УкрНДНЦ", 2017. 32 с.

3. ДСТУ Б В.2.6-210-2016. Оцінка технічного стану сталевих будівельних конструкцій, що експлуатуються. [На заміну ДБН 362-92; чинний $з$ 2017-01-01]. Вид. офіц. Київ : Мінрегіон України, 2016. 46-51с.

4. Барашиков А. Я. Оценка технического состояния строительных конструкций, зданий и сооружений / А. Я. Барашиков, А. Н. Малышев. - Киев: НМЦ Держнаглядохоронпраці України, 1998. - 23 с.

5. ДБН В. 1.2-14-2018. Загальні принципи запезпечення надійності та конструктивної безпеки будівель та споруд. [Чинний з 2019-01-01]. Вид. офіц. Київ : Мінрегіонбуд України, 2018. 29 c. 
6. ДБН В.1.2-9-2008. Система забезпечення надійності та безпеки будівельних об єктів. Основні вимоги до будівель і споруд. Безпека експлуатації. [Чинний з 2008-10-01 ]. Вид. офіц. Київ : Мінрегіонбуд України, 2008. 21с.

7. Учебное пособие програмный комплекс Лира-Сапр 2013 / [Д. А. Городецкий, М. С. Барабаш, Р. Ю. Водопьянов та ін.]. - Киев - Москва: Электронное издание, 2013. - 376 с.

8. ДБН В.2.6-198:2014. Сталеві конструкції. Норми проектування. [чинні з 2015-01-01] Вид. офіц. Київ : Мінрегіон України, 2014. 199 с.

\title{
References
}

[1] DBN V.3.1-1-2002. Remont i pidsylennia nesuchykh i ohorodzhuvalnykh budivelnykh konstruktsii i osnov promyslovykh budynkiv ta sporud. [Chynnyi z 2017-04-01]. Vyd. ofits. Kyiv : DP "UkrNDNTs", 2017. $82 \mathrm{s.}$

[2] DSTU-N B V.1.2-18:2016. Nastanova shchodo obstezhennia budivel i sporud dlia vyznachennia ta otsinky yikh tekhnichnoho stanu. [Chynnyi z 2017-04-01]. Vyd. ofits. Kyiv : DP "UkrNDNTs", 2017. $32 \mathrm{~s}$.

[3] DSTU B V.2.6-210-2016. Otsinka tekhnichnoho stanu stalevykh budivelnykh konstruktsii, shcho ekspluatuiutsia. [Na zaminu DBN 362-92; chynnyi z 2017-01-01]. Vyd. ofits. Kyiv : Minrehion Ukrainy, 2016. 46-51s.

[4] Barashykov A.Ia., Malishev O.M. Otsenka tekhnycheskoho sostoianyia stroytelnыkh konstruktsyi, zdanyi y sooruzhenyi : NMTs Derzhnahliadokhoronpratsi Ukrainy, 1998. $23 \mathrm{~s}$.

[5] DBN V. 1.2-14-2018. Zahalni pryntsypy zapezpechennia nadiinosti ta konstruktyvnoi bezpeky budivel ta sporud. [Chynnyi z 2019-01-01]. Vyd. ofits. Kyiv : Minrehionbud Ukrainy, 2018. $29 \mathrm{~s}$.

[6] DBN V.1.2-9-2008. Systema zabezpechennia nadiinosti ta bezpeky budivelnykh ob iektiv. Osnovni vymohy do budivel i sporud. Bezpeka ekspluatatsii. [Chynnyi z 2008-10-01 ]. Vyd. ofits. Kyiv : Minrehionbud Ukrainy, 2008. 21s.

[7] Horodetskyi D.A., Barabash M.S., Vodopianov R.Iu., Tytok V.P., Artamonova A.E. Uchebnoe posobye prohramnыi kompleks Lyra-Sapr 2013: uchebnoe posobye. Moskva: Эlektronnoe yzdanye, 2013. $376 \mathrm{~s}$.

[8] DBN V.2.6-198:2014. Stalevi konstruktsii. Normy proektuvannia. [chynni z 2015-01-01] Vyd. ofits. Kyiv : Minrehion Ukrainy, 2014. 199 s.

\section{ПЦДСИЛЕННЯ ІСНУЮЧОЇ НЕСУЧОЇ КОНСТРУКЦІЇ ПОКРИТТЯ}

\author{
Романенко C.M., старший викладач \\ romanesko666@gmail.com, ORCID: 0000-0002-0443-3896 \\ Андрісвська Я.П., асистент \\ ДВНЗ «Херсонський державний аграрний університет» \\ yanaandrievska321@gmail.com, ORCID: 0000-0003-3052-2515
}

\begin{abstract}
Анотація. Сонячна енергетика світу зростає експоненційними темпами і тому на сьогоднішній день ефективним рішенням $є$ впровадження сонячних електростанцій. Встановлення альтернативних джерел потрібно починати із проведення енергетичного аудиту, обстеження будівель та споруд, розробки проектної документації. Встановлення нового технічного обладнання на даху веде до зростання навантаження на несучі конструкції. У зв’язку з цим несучі елементи каркасу будівлі потребують підсилення.

В статті наведено результати візуального та інструментального обстеження зернового складу розташованого в сільськогосподарському комплексі згідно якого виявлені деформації конструкцій покриття.

Необхідним елементом обстеження $€$ перевірочний розрахунок конструкцій 3 урахуванням їх фактичного стану. Перевірочний розрахунок конструкцій з урахуванням
\end{abstract}


впливу дефектів і пошкоджень виконувався з метою: можливості подальшої експлуатації без будь-яких обмежень; необхідність підсилення конструкцій.

Об'єктом дослідження $є$ існуючі металеві конструкції балкового типу - ферми, а предметом дослідження - методи раціонального підсилення і регулювання зусиль у таких конструкціях.

У зв'язку збільшенням навантаження та недостатнім перерізом елементів ферми запропоновано зміна статичної схеми ферми за допомогою встановлення додаткових елементів решітки - шпренгелів.

Розрахунок ферми полягає у визначенні поздовжніх зусиль в усіх іiї стержнях, які в подальшому будуть використовуватись у підборі (перевірці) поперечного перерізу іï елементів.

Дослідження виконано із застосуванням класичних розрахунків будівельної механіки та методів комп'ютерного моделюючого експерименту в програмному комплексі «Ліра САПР 2013», який алгоритмічно базується на методі скінчених елементів.

Запропоновано раціональний варіант підсилення несучих конструкцій.

Влаштування сонячних панелей на покрівлі будівлі можлива за умови розробки робочого проекту на підсилення елементів металевої ферми.

Ключові слова: ферма, підсилення, шпренгель, навантаження, переміщення, прогин

\title{
STRENGTHENING OF THE EXISTING BEARING STRUCTURE OF THE COATING
}

\author{
Romanenko S.M., senior lecturer \\ romanesko666@gmail.com, ORCID: 0000-0002-0443-3896 \\ Andrievska Y.P., assistant \\ Kherson State Agrarian University \\ yanaandrievska321@gmail.com, ORCID: 0000-0003-3052-2515
}

Summary. The solar power of the world is growing at an exponential rate and so today is an effective solution to the introduction of solar power plants. The installation of alternative sources should start with energy audits, building and facility surveys, project documentation development. Installation of new technical equipment on the roof increases the load on the supporting structures. In this regard, the supporting elements of the building frame need reinforcement.

The article presents the results of visual and instrumental examination of the grain composition located in the agricultural complex according to which deformations of the cover structures were revealed. A necessary element of the survey is to check the design of the structures, taking into account their actual condition. Verification calculation of structures, taking into account the effect of defects and damages, was carried out with the aim of: possibility of further operation without any restrictions; the need to strengthen the structures.

The object of the study is the existing metal structures of the beam type - the farm, and the subject of the study are the methods of rational reinforcement and regulation of effort in such structures.

Due to the increased load and insufficient cross-section of the farm elements, it is suggested to change the static scheme of the farm by installing additional elements of the grid - struts.

The calculation of the farm is to determine the longitudinal efforts in all its rods, which will later be used in the selection (verification) of the cross-section of its elements.

The study was performed using classical calculations of construction mechanics and methods of computer simulation experiment in the software complex "Lira CAD 2013", which is algorithmically based on the finite element method.

The rational variant of strengthening of load-bearing structures is offered.

The installation of solar panels on the roof of a building is possible provided that a working project is developed to strengthen the elements of the metal farm.

Key words: farm, strengthening, tendon, load, displacement, deflection 


\section{ПІДСИЛЕННЯ КОНСТРУКЦІЙ ОДЕСЬКОГО ДЕРЖАВНОГО ЦИРКУ}

Твардовський I.O., к.Т.Н., доцент, igortvardovsky@gmail.com, ORCID: 0000-0003-4897-5272

Чучмай С.M., к.Т.н., доцент, bran9942@gmail.com, ORCID: 0000-0002-5295-0820

Чучмай О.М., к.т.н., ст. викл., alexsandrch14061983@gmail.com, ORCID: 0000-0002-5856-623X (Одеська державна академія будівництва та архітектури)

Яременко Н.О., к.Т.н., доцент odessa_1@ukr.net, ORCID: 0000-0002-8510-4938 (Одеський національний морський університет)

Анотація. В даній статті розглядається проблематика підсилення конструкцій арокферм, що утримують купол Одеського державного цирку (рис.1), у зв'язку зі збільшенням навантаження від ваги реквізитів, які інколи встановлюють при підготовці до показу нової програми виступів. Відсутність реальної картини напружено-деформованого стану в перетинах металевих елементів арок-ферм призводить до відміни або скорочення нової програми виступу, яку пропонують артисти 3 інших міст України та інших держав. Вирішення вище означеної проблеми є актуальною задачею, яка потребує розрахунків із застосуванням сучасних програмних комплексів та результатів досліджень зміни властивостей металу при тривалій експлуатації металевих конструкцій.

Ключові слова: арки-ферми, можливість збільшення навантаження, підсилення конструкцій, результати розрахунків, обмеження навантаження, безпечна експлуатація.

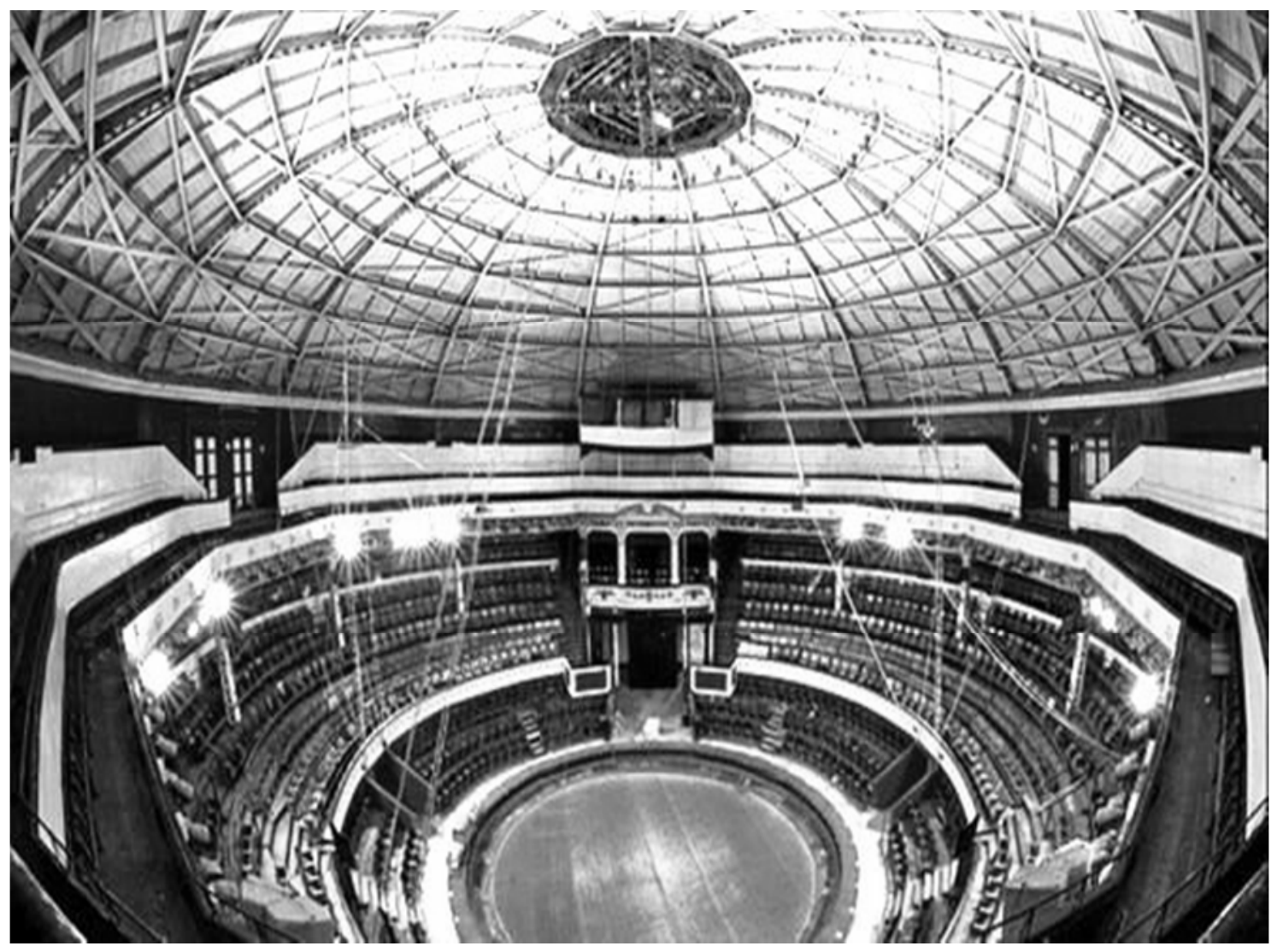

Рис.1. Фото купола над ареною цирку. 
Вступ. Використання стиснутих металевих елементів в існуючих просторових конструкціях, у тому числі куполів, потребує врахування можливості втрати їх стійкості при збільшенні навантаження, яке сьогодні регламентується сучасними нормами та необхідністю створення умов подальшої безпечної експлуатації. Означена проблема має як теоретичне так i практичне значення та потребує продовження досліджень можливості підвищення надійності експлуатації існуючих металевих просторових конструкцій давньої будівлі.

Аналіз останніх досліджень і публікацій. Розрахунки та проектування куполів 3 несучими арочними фермами розглянуто в роботах [1-3], в яких надається методика розрахунку арочних ферм, яка базується на виділенні плоских розрахункових схем 3 просторових систем. У випадку оцінки експлуатаційної здатності конструкцій куполів минулих роуів побудови урахування сучасних діючих нормативних вимог [4-7] потребує перегляду несучої здатності та стійкості конструкцій з застосуванням сучасних програмних комплексів, які дають змогу виявити залишкові резерви та врахувати сумісну роботу елементів просторової системи.

Метою роботи. Визначення несучої здатності металевих конструкцій куполу будівлі Одеського цирку і з'ясування можливості збільшення експлуатаційного навантаження від навісного обладнання для виступу циркових артистів і забезпечення їх надійної експлуатації.

Результати досліджень. Будівля Одеського цирку є найстарішою в Україні серед просторових споруд. Вона будувалася за проектом інженера А.Гольфанда із металевих конструкцій, запроектованих і виготовлених у Німеччині. Каркас його зроблений з металу німецького виробництва, склад якого невідомий, але він не іржавіє і не піддається зварці. Відкритий був «залізний цирк» або «Цирк-вар'єте» тільки в 1894 р., в рік сторіччя Одеси. Будівля виросла між вулицями Коблевською та Садовою - величезна за тими мірками, кам'яна, дванадцятикутної форми, з великим подвійним залізним куполом. Усередині була своя природна вентиляція - влітку прохолодно, а взимку - тепло. Партер напівкруглий, 3 п’яти лав (365 місць). Конструкції, на яких влаштовані партер, ложі, перші і другі місця, галереї - залізні. У партері - гнуті стільці з сидіннями, що піднімаються при вставанні, в других місцях - красиві лави з такими ж сидіннями. За кріслами 40 лож, за ними 480 перших місць, потім 346 других місць, а вище - галерея на 1000 глядачів, без сидінь. Освітлювався цирк електрикою з міської станції. 3 правого боку головного входу - двоповерхова будівля, де на нижньому поверсі розташований зал для репетицій балету, гімнастів, переодягальні для артистів і наїзників. Незвичність Одеського цирку полягає в тому, що відстань від манежу до верху куполу становить 22 метри, тоді як стандарт - 18 метрів.

В конструктивному рішенні купол Одеського цирку виконаний з дванадцяти арок-ферм (рис2), які поєднані по висоті горизонтальними, діагональними та хрестовими в'язями жорсткості. Для виготовлення нижнього і верхнього поясів ферм-арок були використані парні кутики, а розкоси виконані з пластин. Всі металеві елементи між собою з'єднані на заклепках.
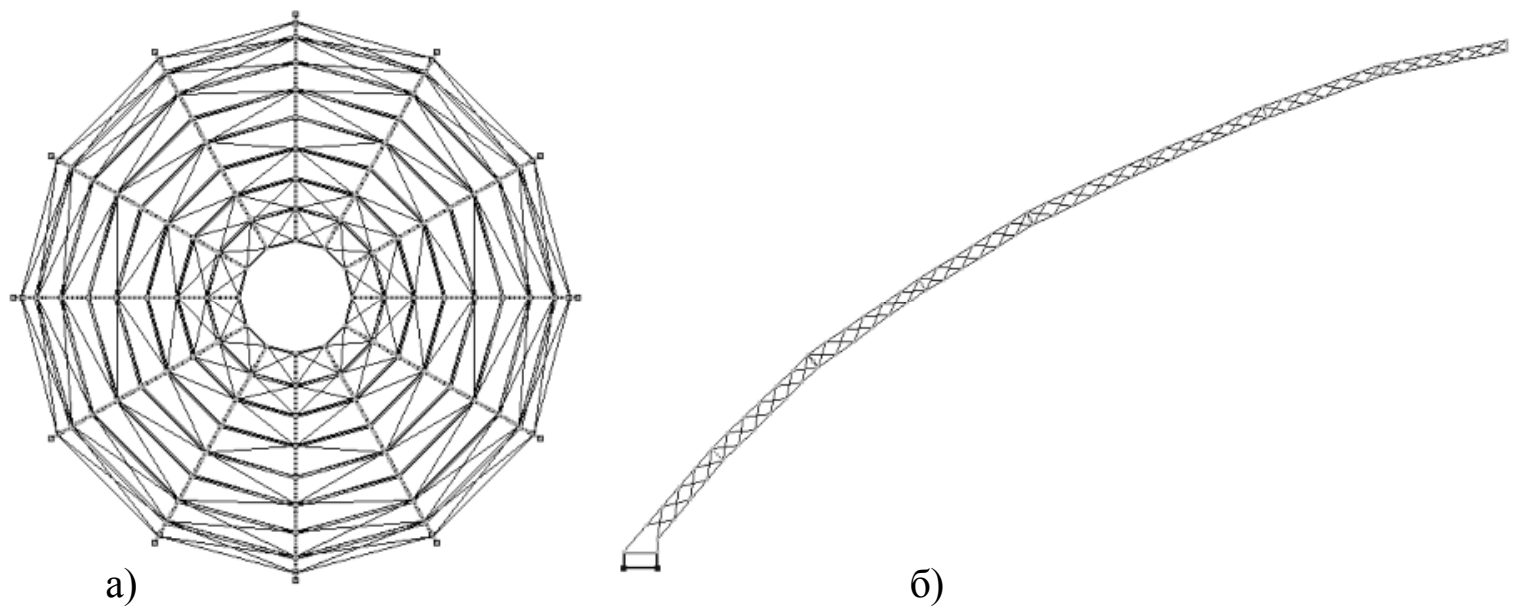

Рис.2. План-схема розміщення арок-ферм, ребер жорсткості купола, 
горизонтальних і діагональних в'язів (а); перетин напіварки-ферми (б).

3'єднання верхніх поясів ферм-арок 3 дерев'яною обрешіткою, яка сформувала поверхню оболонки купола, було виконано на болтах. Поверхня купола захищена від атмосферних опадів шарами м'якої покрівлі із сучасних матеріалів.

3 часом і розвитком розважальної циркової індустрії виникла необхідність підсилення несучих металевих конструкцій купола - арок-ферм, що несуть колосниково-хрестову замкнену кільцеву ферму, на яку підвішують обладнання, декорації, а також обпираються стіни технічного приміщення. Ферми куполу працюють в основному на динамічне навантаження, яке може змінюватися в залежності від програми виступу циркових артистів та ваги застосованого обладнання. Необхідно також ураховувати те, що при сприйнятті навантаження різні частини кожної металевої ферми-арки ведуть зазнають різного напружено-деформованого стану: якщо у верхній частині конструкція вигинається до низу, то в середній частині - догори.

3 часом в конструкції куполу виявилася проблемна ділянка - опорні вузли арочних ферм (рис.3), а саме: металеві елементи опорних вузлів, які сприймають горизонтальний розпір, потребували збільшення жорсткості. Для вирішення проблем, які виникли 3 опорними вузлами було здійснено їх підсилення шляхом додавання по нижньому поясу арки-ферми двох кутиків, які закріплені болтами до кутиків нижнього кругового поясу і до елементів самої решітки. Існуючі опорні башмаки і нижнє контурне кільце куполу було очищено від іржі, обмотано тонким дротом та забетоновано.

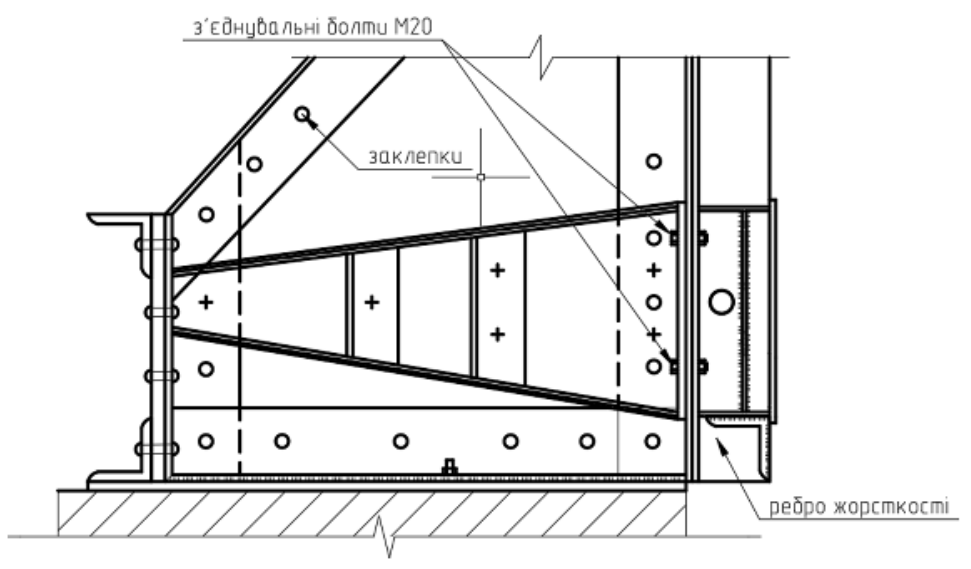

Рис. 3. Опорний вузол (з архівних матеріалів)

Для перевірки ефективності виконаного підсилення та визначення наявності резерву несучої здатності несучих ферм-арок купола та їх роботу у просторовій розрахунковій схемі (рис.4) проведений розрахунок 3 допомогою програмного комплексу ЛІРА-САПР. 3 розвитком комп'ютерної індустрії з'явилися набагато більші можливості, що допомагають побудувати більш точніші розрахункові схеми та змоделювати більш реалістичні навантаження й урахувати зношеність конструкцій. Це призводить до підвищення надійності, міцності та довговічності при реконструкції споруд попередніх часів забудови.

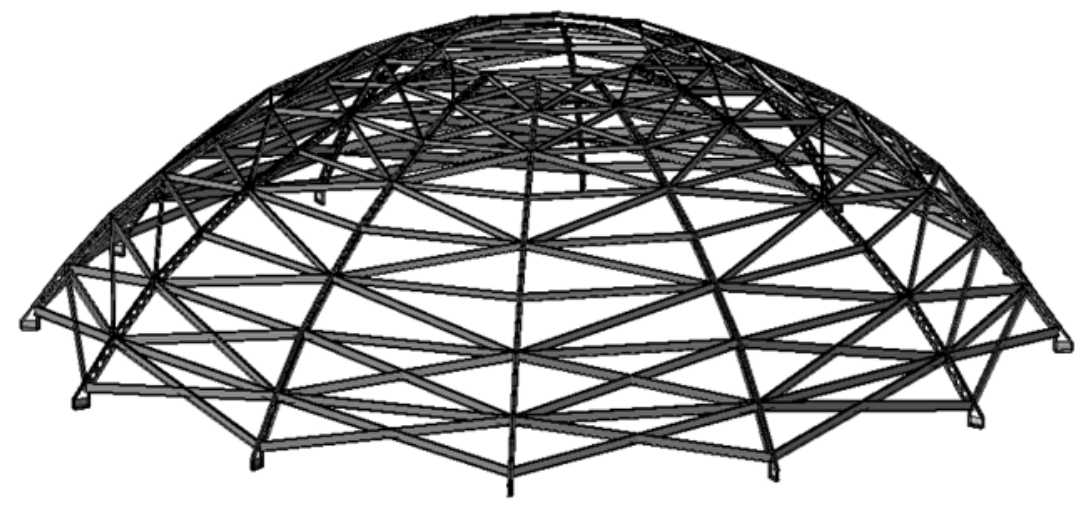


Рис. 4. Візуалізована 3D модель купола

Розрахунок куполу виконувався з урахуванням діючих навантажень (рис. 5): власної ваги (а); ваги від технічного приміщення з обладнанням для підвісу конструкцій реквізиту артистів, що виступають (б); навантаження від снігу (в); від вітру (г); сейсмічного впливу.

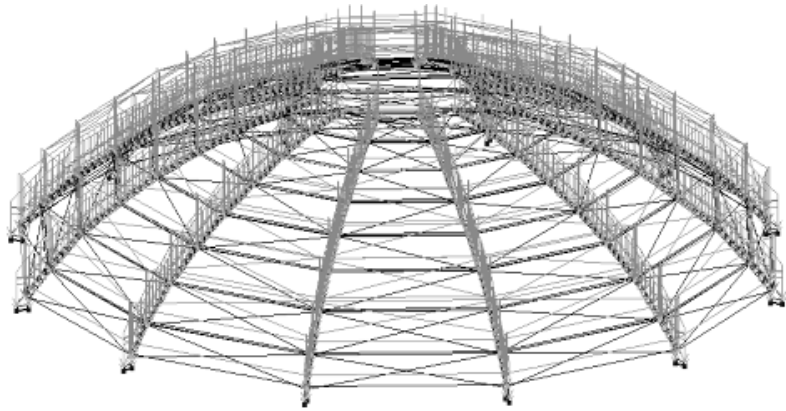

а) навантаження від власної ваги

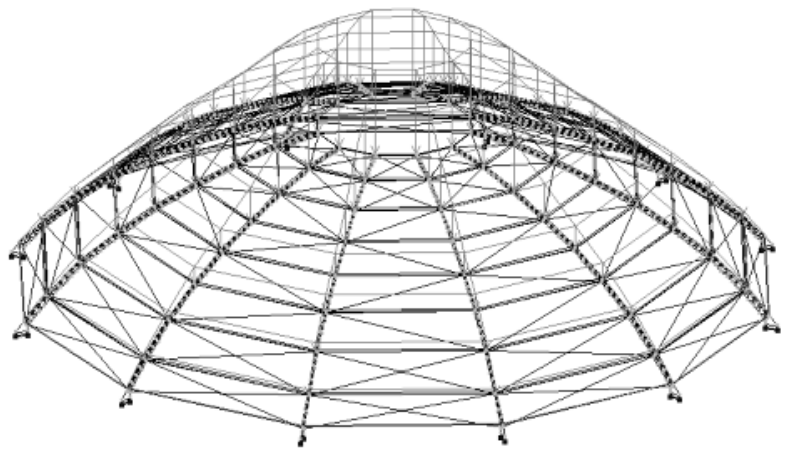

в) навантаження від снігу

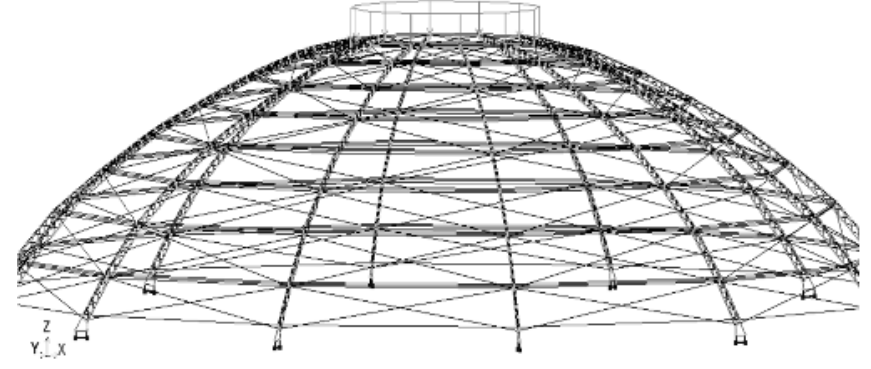

б) навантаження від технологічного обладнання

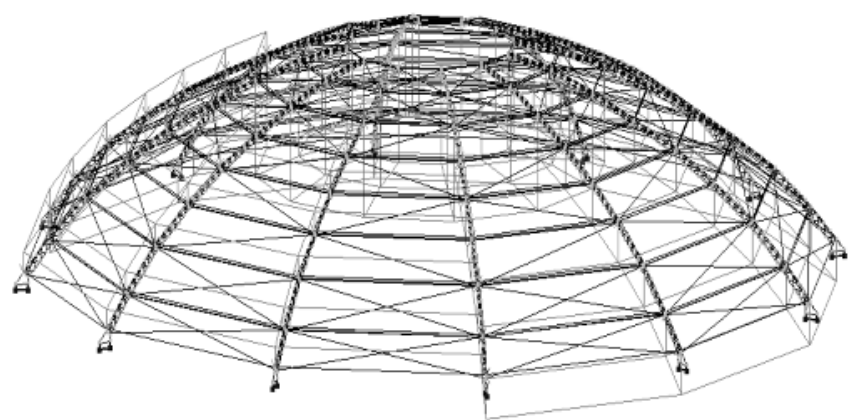

г) навантаження від вітру

Рис. 5. Основні навантаження, які враховувалися при розрахунку купола

Нижче наведені результати розрахунків переміщень купола (рис.6)

а) переміщення від технологічного обладнання

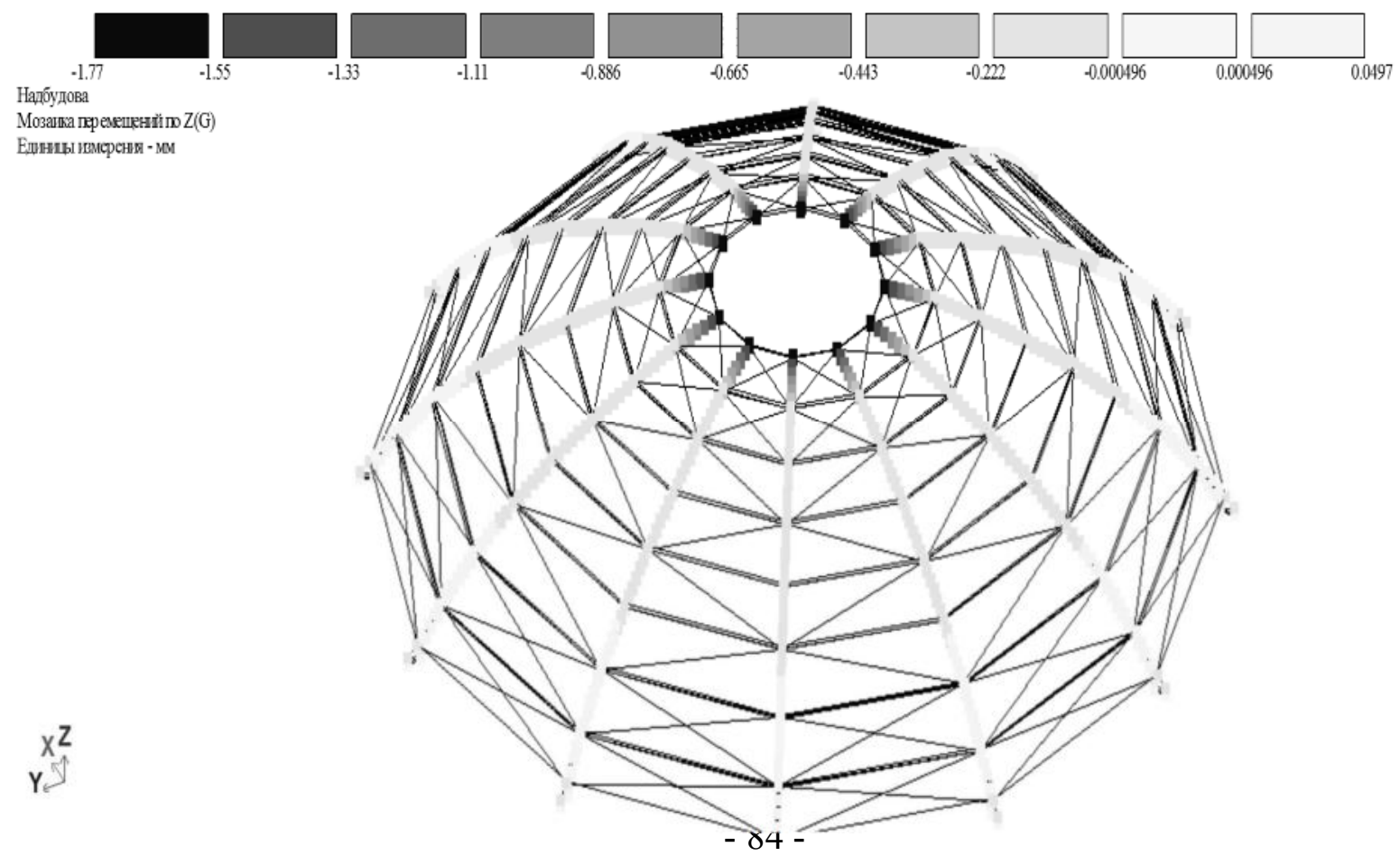


б) переміщення від граничного навантаження

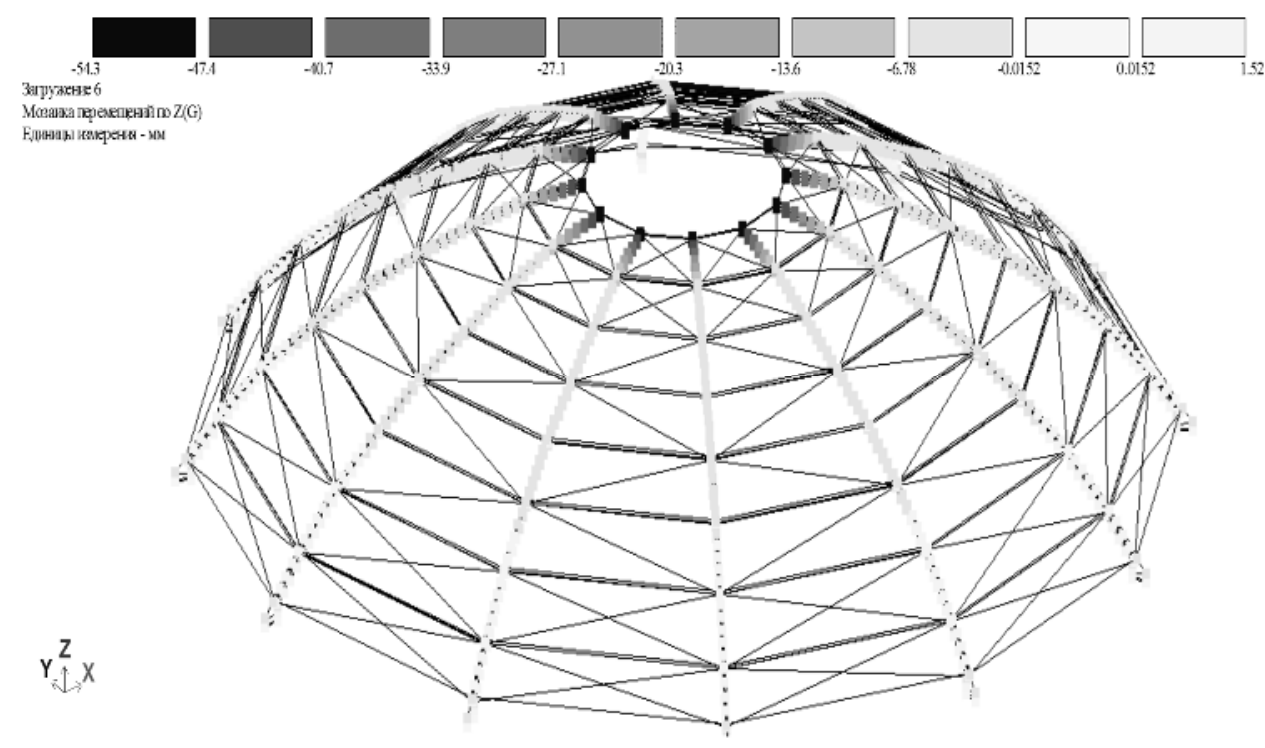

в) переміщення від сейсмічного навантаження

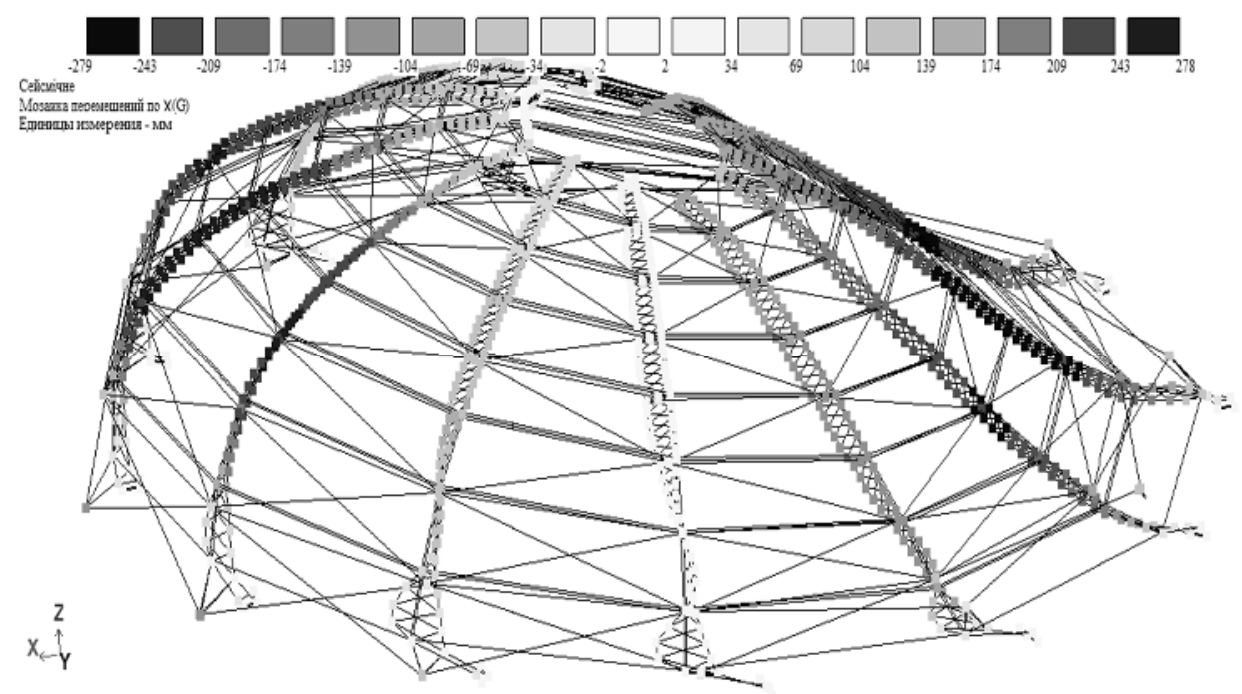

Рис. 6. Результати визначених переміщень від розрахункових навантажень

За результатами виконаного комп'ютерного моделювання й розрахунку отримано значення деформацій і внутрішніх зусиль в елементах конструкції ферм-арок при дії статичних і динамічних навантажень, а також виявлене максимальне допустиме граничне навантаження. Аналіз отриманих результатів розрахунку куполу надав змогу прийняти відповідні правильні рішення щодо можливості збільшення динамічного навантаження, потреба в якому виникає з часом при виступі артистів цирку, та необхідності додаткового підсилення для забезпечення подальшої надійної експлуатації споруди при урахуванні сучасних нормативних вимог.

\section{Висновки і перспективи подальших досліджень:}

В ході аналізу чисельного дослідження напруженно-деформованого стану несучих конструкцій куполу (арок-ферм) на підставі виконаних розрахунків були отримані наступні результати:

1. Конструкція куполу будівлі Одеського цирку витримує всі діючі на даний час навантаження, які регламентовані сучасними нормативними документами. 
2. Конструкція арок-ферм куполу може не підлягати підсиленню, але за умови належної експлуатації без збільшення діючих навантажень.

3. Додаткове навантаження для визначення граничної несучої здатності показало, що при досягненні значення навантаження 10кН/м 3'являється надмірний і недопустимий прогин, що може призвести до втрати несучої здатності конструкції.

4. На підставі виконаних розрахунків рекомендована максимальна величина навантаження по верхньому кільцю (у місці розташування стінок технічного приміщення та ваги технологічного обладнання з вагою реквізиту циркових артистів), яка становить $8 \mathrm{\kappa H} / \mathrm{M}$.

5. Для збільшення навантаження на купол більш, ніж 8 кН/м, необхідно прийняти заходи щодо підсилення несучих конструкцій, зокрема елементів опорного вузла та нижніж поясів несучих фер (ребер купола) на стику з опорними вузлами.

6. Враховуючи тривалість експлуатації купола будівлі Одеського цирку подальші дослідження несучої здатності несучих арок-ферм купола мають бути продовжені для гарантування їх подальшої безпечної експлуатації.

\section{Література}

1. Баженов В. А. Будівельна механіка / В.А.Баженов - К. : Вища школа, 2000. - 670 с.

2. Бабічев П.Є. Розрахунок підсилення кроквяних ферм підведенням поздовжньої вертикальної ферми / П.С. Бабічев // Збірник наукових праць Українського інституту сталевих конструкцій ім. В.М. Шимановського. - Видавництво «Сталь», Киӥв.- Вип.9, 2012. C. $79-92$.

3. О.О.Нілов. Металеві конструкції. Загальний курс. /О.О.Нілов, В.О.Пермінов, О.В.Шимановський, С.І.Білик, Л.Г.Лавріненко, І.Д.Бєлов, В.О.Володимирський // Підручник для Вищих навчальних закладів.- Видавництво «Сталь», Київ, 2010. - 869 с.

4. Навантаження і впливи : ДБН В.1.2-2:2006 - [Чинний від 2017-10-1] - К.: Мінрегіон України, 2006. - 110 с. - (Державні будівельні норми України).

5. Сталеві конструкції: ДБН В.2.6-198:2014 - [Чинний від 2015-1-1] - К.: Держспоживстандарт України, 2014.-127с. - (Державні будівельні норми України).

6. Будівництво у сейсмічних районах України : ДБН В.1.1-12:2014 - [Чинний від 201507-1] - К. : Мінрегіон України, 2014. -110с. (Державні будівельні норми України).

7. Прогини і переміщення. Вимоги проектування: ДСТУ Б В.1.2-3:2006 - [Чинний від 2007-1-1] - К. : Мінбуд України, 2006.-15с. - (Національний стандарт України).

\section{References}

[1] Bazhenov V.A. Budivelna mehanika / V.A. Bazhenov - K.: Vishcha school, 2000. - 670 p.

[2] Babichev P.C. Rozrahunok p_dsilennya krokvyanyi farms povedenennyam pozdvzhnyo vertically fermi / P.C. Babichev // Zbirnik naukovikh prats Ukranianskiy Institute of Steel Design im. V.M. Shimanovsky. - Vidavnitsvo "Steel", Kiev. - VIP. 9, 2012 - S. 79-92.

[3] O.O.Nilov. Metal construction. Ignition course. / O.O. Nilov, V.O. Perminov, O.V.Shimanovsky, S.I. Bilik, L.G. Lavrinenko, I.D. Bєlov, V.O. Volodimirsky // Pidruchnik for Vishchikh vlichnyh mortgages. - Vidavnitsvo "Steel", Kyiv, 2010. - 869 p.

[4] Navantazhny i vplivy: DBN V.1.2-2: 2006 - [Chinniy vid 2017-10-1] - K.: Ministry of Ukraine, 2006. - 110 p. - (The State Daily Norms of Ukraine)

[5] Steel construction: DBN V.2.6-198: 2014 - [Chinniy vid 2015-1-1] - K.: Holding the standard of Ukraine, 2014.-127p. - (The State Daily Norms of Ukraine

6. Construction in seismic regions of Ukraine: DBN B.1.1-12: 2014 - [Effective from 201507-1] - K.: Ministry of Regional Development of Ukraine, 2014. -110s.

[7] Run and change. Vimogi project: DSTU B V.1.2-3: 2006 - [Chinniy vid 2007-1-1] - K.: Minbud of Ukraine, 2006.-15p. - (National Standard of Ukraine) 


\title{
STRENGTHENING DESIGN OF THE ODESSA HOLDING CIRCUS
}

Tvardovsky I.O., Ph.D., associate professor, igortvardovsky@gmail.com, ORCID: 0000-0003-4897-5272

Chuchmay S.M., Ph.D., associate professor, bran9942@gmail.com, ORCID: 0000-0002-5295-0820

Chuchmai O.M., Ph.D., assistant professor, alexsandrch14061983@gmail.com, ORCID: 0000-0002-5856-623X (Odessa State Academy of Architecture and Architecture)

Yaremenko N.O., Ph.D., associate professor, odessa_1@ukr.net, ORCID: 0000-0002-8510-4938

(Odessa National Maritime University)

\begin{abstract}
Annotation. In this article, various designs are available that provide high quality data, as well as requirements for the weight of details that require installation in preparation for the presentation of new programs of performances. Lack of analysis of the real picture of the stressstrain state in the sections of the metal elements of arch trusses leads to the cancellation or reduction of the new program of performances, which are offered by artists from other cities of Ukraine and other countries. The solution to the existing problem is an urgent task that requires calculations using modern software systems and the results of studies of changes in the properties of metal during the long-term operation of metal structures.

With the development of the computer industry, much greater opportunities have appeared that help to build more accurate design schemes and simulate more realistic loads and take into account the deterioration of structures. This leads to increased reliability, strength and durability during the reconstruction of structures of long-time construction.

To check the effectiveness of the amplification performed and to determine the presence of the load-bearing capacity reserve of the bearing truss dome arches and their operation in the spatial calculation scheme, the calculation was performed using the LIRA-SAPR software package.

The performed computer modeling and calculation made it possible to obtain the values of deformations and internal forces in the structural elements of truss arches under the action of static and dynamic loads, as well as to determine the maximum permissible ultimate load.

The analysis of the dome calculation results made it possible to take the appropriate correct decisions regarding the possibility of increasing the dynamic load that arises with time when circus performers meet, or the need for additional reinforcement of structures to ensure reliable operation of the building, taking into account current regulatory requirements.

Based on the calculations, it is recommended that the maximum load on the upper ring (at the location of the walls of the technical room and the weight of the process equipment with the weight of the props of the performing circus artists), which is $-8 \mathrm{kN} / \mathrm{m}$.

Upon reaching a load value of $10 \mathrm{kN} / \mathrm{m}$, an unacceptable deflection appears, which can lead to a loss of the bearing capacity of the structure. To increase the load on the dome more than the recommended value of $8 \mathrm{kN} / \mathrm{m}$, it is necessary to carry out measures to strengthen the supporting structures, especially the elements of the support unit and the lower belts of the bearing ferries (dome ribs) at the junction with the support nodes.
\end{abstract}

Keywords: arch trusses, the possibility of increasing the load, strengthening structures, calculation results, load limitation, safe operation. 


\title{
УСИЛЕНИЕ КОНСТРУКЦИЙ ОДЕССКОГО ГОСУДАРСТВЕННОГО ЦИРКА
}

\author{
Твардовский И.А., к.Т.Н., доцент, \\ igortvardovsky@gmail.com, ORCID: 0000-0003-4897-5272 \\ Чучмай С.M., к.т.н., доцент, \\ bran9942@gmail.com, ORCID: 0000-0002-5295-0820 \\ Чучмай А.М., к.т.н.,ст. преп., \\ alexsandrch14061983@gmail.com, ORCID: 0000-0002-5856-623X \\ (Одеська державна академія будівництва та архітектури) \\ Яременко Н.О., к.т.Н., доцент \\ odessa_1@ukr.net, ORCID: 0000-0002-8510-4938 \\ (Одесский национальный морской университет)
}

\begin{abstract}
Аннотация. В данной статье рассматривается проблематика усиления конструкции арок-ферм, удерживающих купол Одесского государственного цирка, в связи с увеличением нагрузки от веса реквизитов, которые порой требуют установки при подготовке к показу новой программы выступлений. Отсутствие анализа реальной картины по напряженнодеформированному состоянию в сечениях металлических элементов арок-ферм приводит к отмене или сокращении новой программы выступления, которую предлагают артисты из других городов Украины и других государств. Решение существующей проблемы является актуальной задачей, требующей расчетов с применением современных программных комплексов и результатов исследований изменения свойств металла при длительной эксплуатации металлических конструкций.

C развитием компьютерной индустрии появились гораздо большие возможности, помогающие построить более точные расчетные схемы и смоделировать более реалистичные нагрузки и учесть изношенность конструкций. Это приводит к повышению надежности, прочности и долговечности при реконструкции сооружений давних по времени постройки.

Для проверки эффективности выполненного усиления и определения наличия резерва несущей способности несущих ферм-арок купола и их работу в пространственной расчетной схеме произведен расчет с помощью программного комплекса LIRA-SAPR.

Выполненное компьютерное моделирование и расчет позволили получить значения деформаций и внутренних усилий в элементах конструкций ферм-арок при действии статических и динамических нагрузок, а также определить максимально допустимую предельную нагрузку. Анализ полученных результатов расчета купола дал возможность принять соответствующие правильные решения в отношении возможности увеличения динамической нагрузки, которая возникает со временем при виступлении артистов цирка, или необходимости дополнительного усиления конструкций для обеспечения надежной эксплуатации сооружения при учете действующих нормативных требований.

На основании выполненных расчетов рекомендуется максимальная величина нагрузки по верхнему кольцу (в месте расположения стенок технического помещения и веса технологического оборудования с весом реквизита выступающих цирковых артистов), которая составляет - 8 кН/м. При достижении значения нагрузки $10 \mathrm{\kappa H} / \mathrm{M} \mathrm{появляется}$ недопустимый прогиб, что может привести к потере несущей способности конструкции. Для увеличения нагрузки на купол больше чем рекомендуемой величины 8 кН/м необходимо проводить мероприятия по усилению несущих конструкций, особенно элементов опорного узла и нижниж поясов несущих фер (ребер купола) на стыке с опорными узлами.

Ключевые слова: арки-фермы, возможность увеличения нагрузки, усиление конструкций, результаты расчетов, ограничение нагрузки, безопасная эксплуатация.
\end{abstract}




\title{
ОПЫТ МОНТАЖА МЕТАЛЛИЧЕСКОЙ КОНВЕЙЕРНОЙ ГАЛЕРЕИ МЕТОДОМ НАДВИЖКИ
}

\author{
Шеховцов И.В., к.т.н., доцент, \\ ORCID 0000-0003-3664-0723 \\ Петраш С.В., к.т.н., доцент, \\ ORCID 0000-0002-8567-3962 \\ Бондаренко А.В., к.т.н., доцент, \\ Шеховцов В.И., к.Т.Н., доцент \\ Одесская государственная академия строительства и архитектуры \\ v.shekhovtsov@ogasa.org.ua, ORCID: 0000-0001-9499-0188
}

\begin{abstract}
Аннотация. Статья описывает опыт установки металлической 146 метровой конвейерной галереи, устраиваемой над железнодорожными путями, не останавливая эксплуатацию железнодорожного транспорта. Особый интерес представляет примененный метод монтажа, при котором галерея при надвижке меняет свою расчетную схему и, как следствие, усилия в элементах. Монтаж проводился на высоте более 30 м над уровнем железнодорожного полотна. Так как при надвижке расчетная схема галереи изменялась несколько раз, то выполнялся детальный численный анализ поведения опор и каждого из элементов галереи при проведении монтажных работ. Также с помощью методик заложенных в программном комплексе «ЛИРА-САПР» выполнялась оценка динамических характеристик конструкций галереи.
\end{abstract}

Ключевые слова: конвейерная галерея, монтаж методом надвижки, аванбек, отправочная марка, пролетное строение, опора.

Вступ. В апреле 2016 года была начата реконструкция одной из конвейерных линий станции погрузки вагонов на территории погрузочно-разгрузочного района № 2 МТП «ЮЖНЫЙ» расположенного на восточном берегу Малого Аджалыкского (Григорьевского лимана). Реконструкция предусматривает устройство дополнительной конвейерной галереи между станцией погрузки вагонов (в дальнейшем СПВ) и проектируемой станцией разгрузки автомобилей. Общая длина конвейерной галереи - 146 м. Галерея должна проходить над железнодорожными путями.

Цель и постановка задачи. Основным условием, которое было поставлено перед производством работ, была необходимость провести монтаж галереи, при этом не останавливая железнодорожное сообщение.

Анализ существующих публикаций и исследований. Согласно имеющихся сведений и на основании анализа существующих способов монтажа наиболее оптимальным оказался метод постепенной надвижки секций галереи на заранее установленные опоры. Такое решение касательно метода монтажа явилось нетривиальным.

Материалы и методика исследований (конструктивные решения галереи и выбор способа монтажа). В конструктивном плане галерея представляет собой трехпролетное строение. Длина-пролетов по 46.71 м. Галерея опирается на 4 опоры (слева направо): сооружение СПВ, опора Б, опора В и опора Г (рис. 1). СПВ является действующим сооружением, опоры Б, В и Г запроектированы при реконструкции. Опора Б запроектирована по типу «качающейся». Опирание галереи на опору Б - шарнирно подвижное, предусматривающее возможные отклонения опоры от вертикали при температурном расширении. Опоры В и Г запроектированы неподвижными, башенного типа. Опирание галереи на опору В - шарнирно-подвижное, на опору Г - шарнирно - неподвижное. 


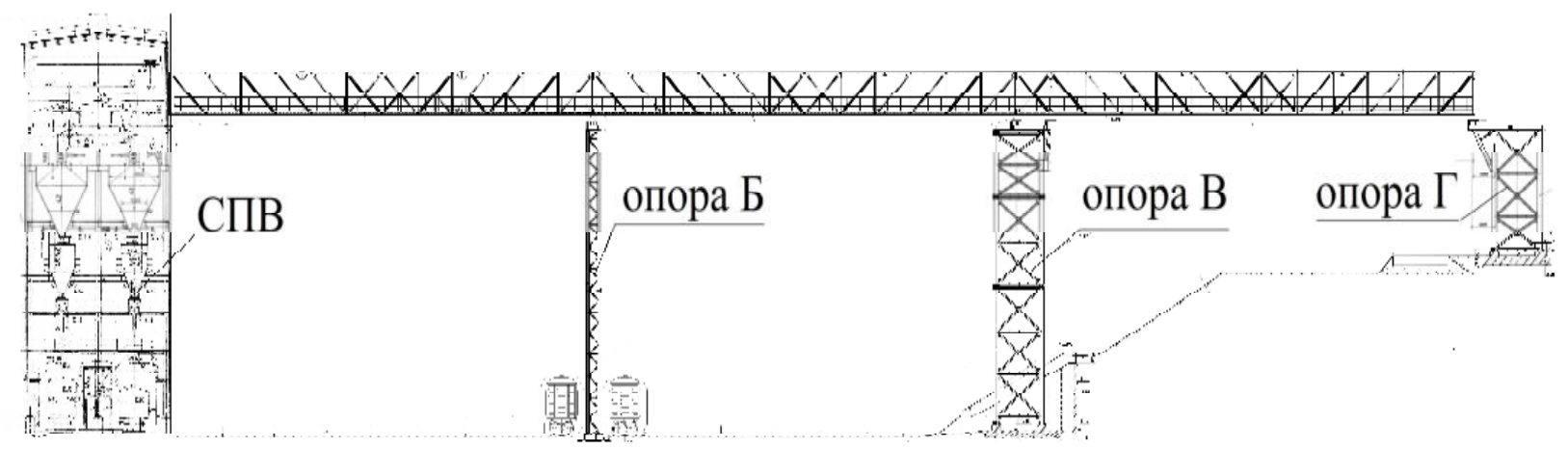

Рис. 1. Общий вид конвейерной галереи

В конструктивном отношении конвейерная галерея состоит из типовых секций длиной 46,71 м и вставки в районе опоры В [2]. Секции состоят из двух стальных ферм с параллельными поясами, объединенных балками пола галереи (по нижнему поясу ферм) и балками по верхнему поясу ферм. По концам каждой секции галереи предусмотрены поперечные рамы с жестким соединением ригеля с опорными стойками ферм.

Панели ферм имеют длину 3,89 м. Фермы имеют по 12 панелей (5 с нисходящими раскосами, 5 с восходящими и по две центральные панели с крестообразной решеткой). Высота ферм в осях 3,8 м.

По нижним и верхним поясам ферм устроены крестовые связи. Конструкции конвейера опираются на второстепенные балки клетки. Настил по второстепенным балкам выполнен из стального просечного листа.

Особенностью выбранного метода монтажа являлось то, что галерея проходит над развитой сетью железной дороги (11 путей) и сопутствующей функциональной инфраструктурой. После тщательного анализа всех возможных вариантов установки галереи в проектное положение, без остановки железнодорожного сообщения, был принят вариант ее последовательной надвижки из крайнего пролета (с опор В и Г) до проектного положения.

Основные этапы надвижки галереи приведены на рис. 2.
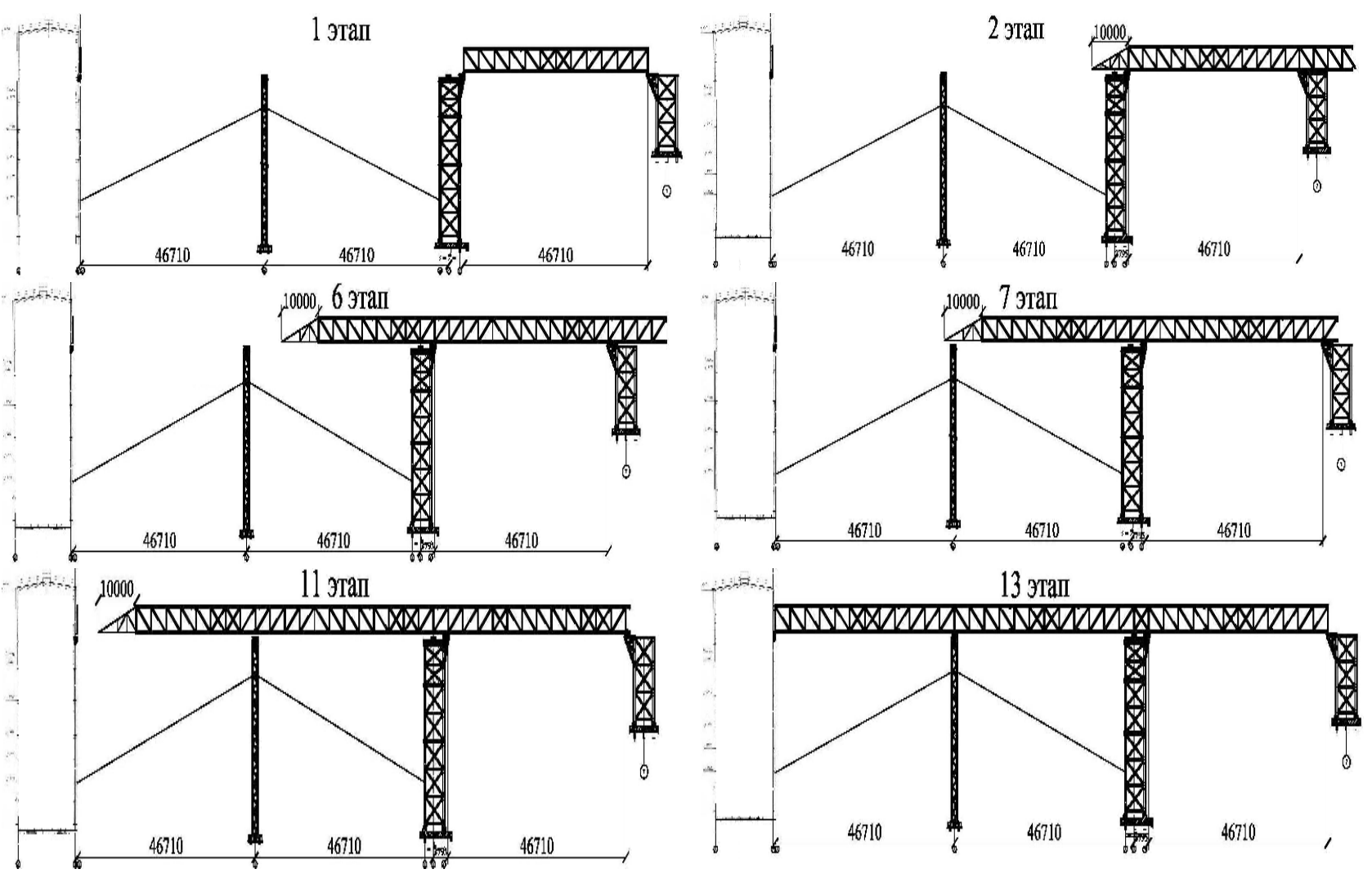
Рис. 2. Основные этапы надвижки галереи (выборочно)

Результаты исследований. Последовательность надвижки была следующей. В крайнем пролете при помощи кранов монтировалась одна секция галереи (на опоры В и Г). К ней крепился аванбек длиной 10 м с одной стороны и отправочная марка с другой стороны. При помощи гидравлических домкратов вся конструкция смещалась по опорам по направлению к СПВ на величину отправочной марки. Последовательно присоединяя при надвижке все отправочные марки, галерея устанавливается в проектное положение. При надвижке «качающаяся» опора Б раскреплялась оттяжками для компенсации горизонтальных усилий.

Расчет галереи проводился при различных сценариях, включающих в себя все монтажные варианты и проектное положение галереи с учетом требований норм [3.4]. Наихудшем случаем при монтаже был сценарий, при котором галерея при надвижке достигает промежуточной опоры (этапы 6 и 11 рис. 2). В этом случае расчетная схема галереи представляла собой консоль длиной 46,7 м. При таком расположении опора галереи, через которую происходит надвижка, приходит не в узел фермы, а в ее панели, в результате чего на стержни нижних поясов ферм воздействуют совместно продольная сила и значительный изгибающий момент.

Нагрузки, на которые рассчитывалась галерея, были подобраны на стадии проектирования. Основными монтажными нагрузками были: собственный вес облегченной галереи (без оборудования конвейерами и без обслуживающих площадок); нагрузки от монтажного оборудования; вес монтажников; вес монтажных площадок.

Для определения ветровых нагрузок на стадии монтажа был проведен мониторинг метеорологических статистических данных. Монтаж конструкций предполагался на августсентябрь месяц. По результатам анализа данных были приняты ветровые нагрузки, соответствующие скорости ветра равной $10 \mathrm{~m} / \mathrm{c}$.

Расчеты конвейерной галереи проводились при помощи программного комплекса «ЛИРА-САПР» (рис. 3). Использование программного комплекса позволило отслеживать напряженно-деформированное состояние элементов конструкций на всех этапах монтажа. Контроль проводился для двух групп предельных состояний как для каждого отдельного элемента галереи, так и для всей конструкции в целом.

По результатам расчетов был построен график зависимости вылета консоли от прогиба для крайней точки аванбека (выборочно материалы представлены на рис. 4). Максимальный расчетный прогиб галереи составил 230 мм при максимальном вылете консоли, равном $46,7 \mathrm{M}$.

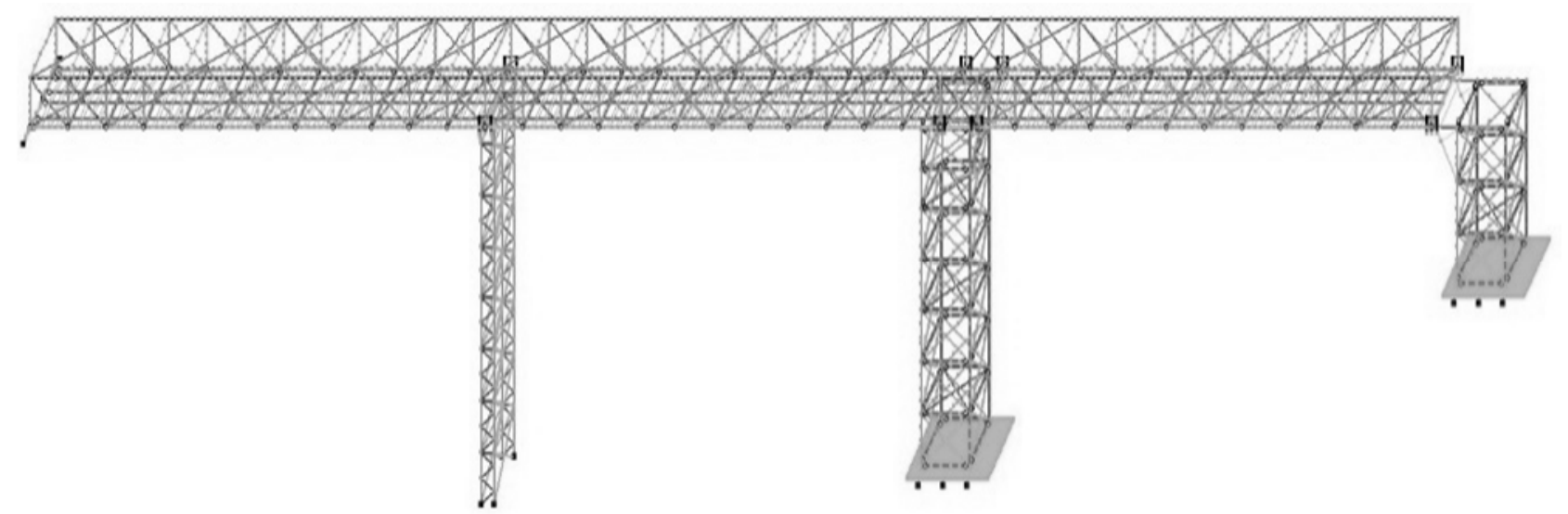

Рис. 3. Расчетная схема в программном комплексе «ЛИРА-САПР» 


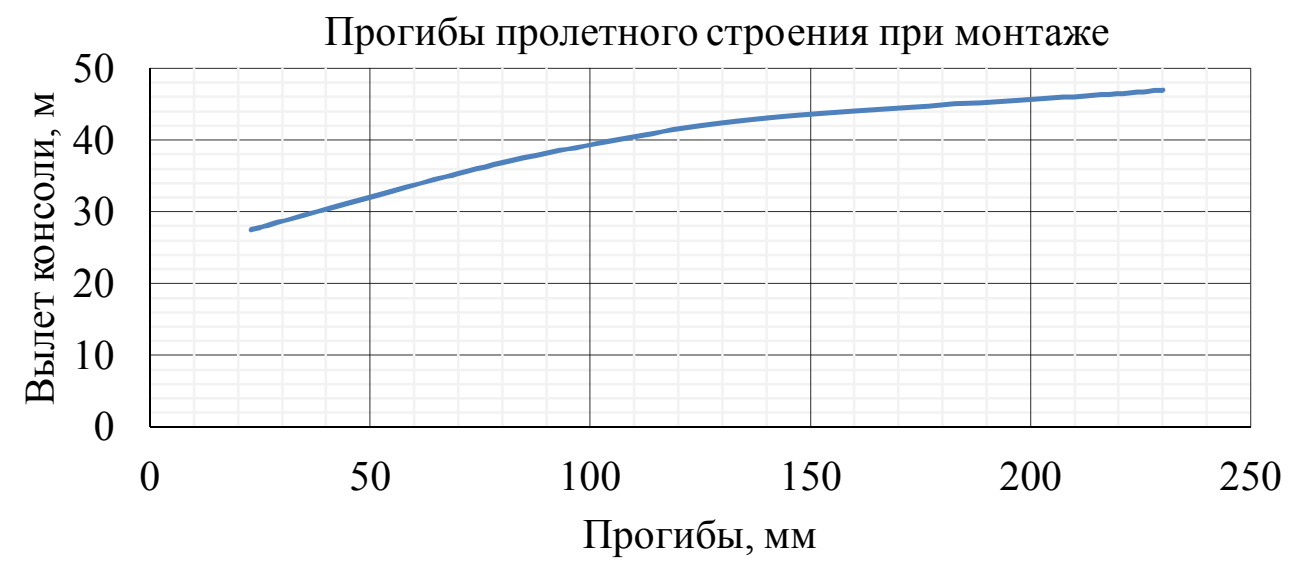

Рис. 4. График зависимости вылета консоли от прогиба

Так же было определено максимальное отклонение «качающейся» опоры Б при надвижке галереи через нее. Максимальное расчетное ее отклонение от вертикали составило $20 \mathrm{~cm}$.

Непосредственно перед началом монтажа галереи была выполнена ее укрупненная сборка. Это позволило провести испытание галереи на монтажные нагрузки до установки в проектное положение, а также проверить расчетные сценарии при надвижке. Прогибы пролетных строений галереи в проектном положении от действия собственного веса конструкций практически совпал с расчетными значениями. Прогиб при максимальном вылете консоли 46,7 м превысил расчетные значения на 50 мм и составил 280 мм. Прочность элементов галереи по результатам испытаний была обеспечена. Превышение фактического прогиба консоли галереи при монтаже потребовало внесение изменений в конструкцию аванбека. На рисунках 7,8 приведены фотографии галереи во время надвижки и в проектном положении.

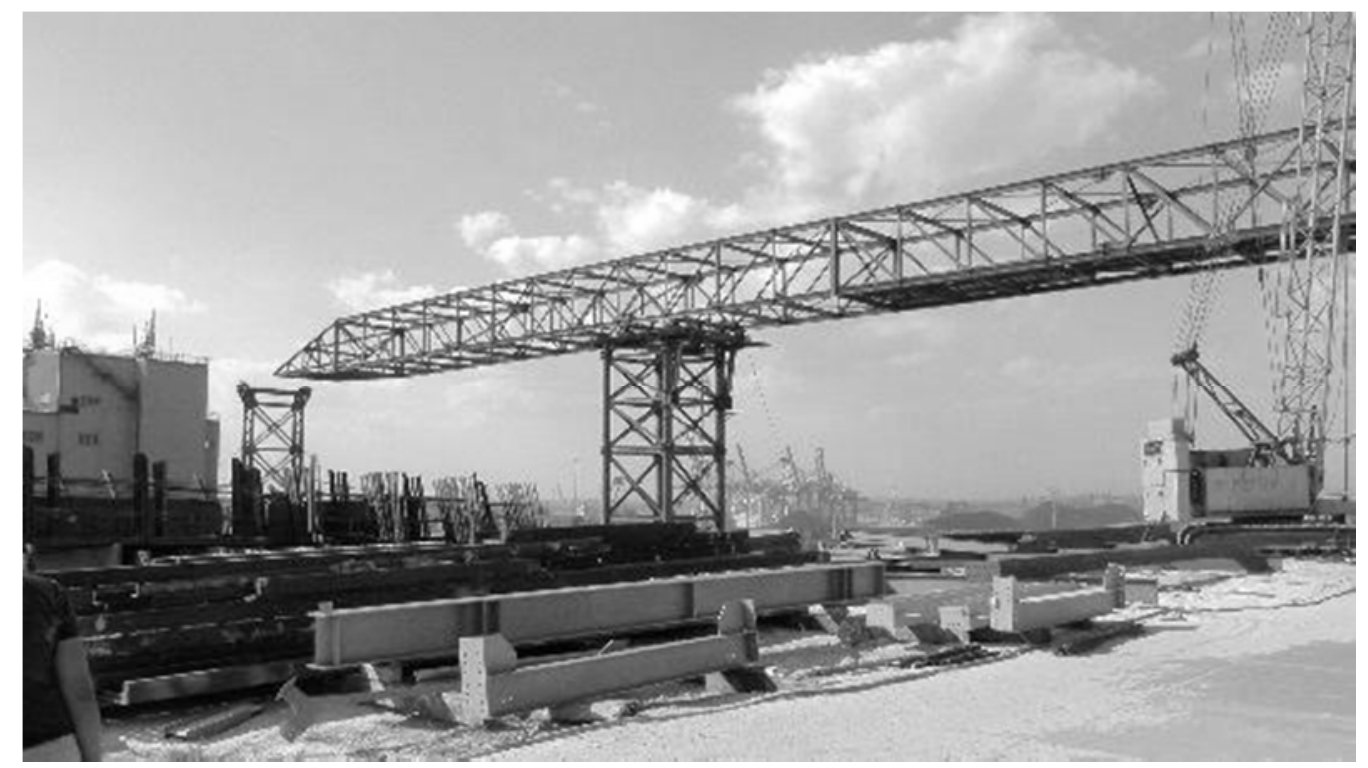

Рис. 5. Галерея во время надвижки

Превышение прогибов консоли объясняется наличием строительного подъема в каждой секции галереи и сложностью корректного учета его при расчете, а также неизбежными незначительными неточностями при сборке конструкции галереи.

Контролировать прогиб консоли галереи при надвижке на всем этапе не предоставлялось возможным по техническим причинам. 


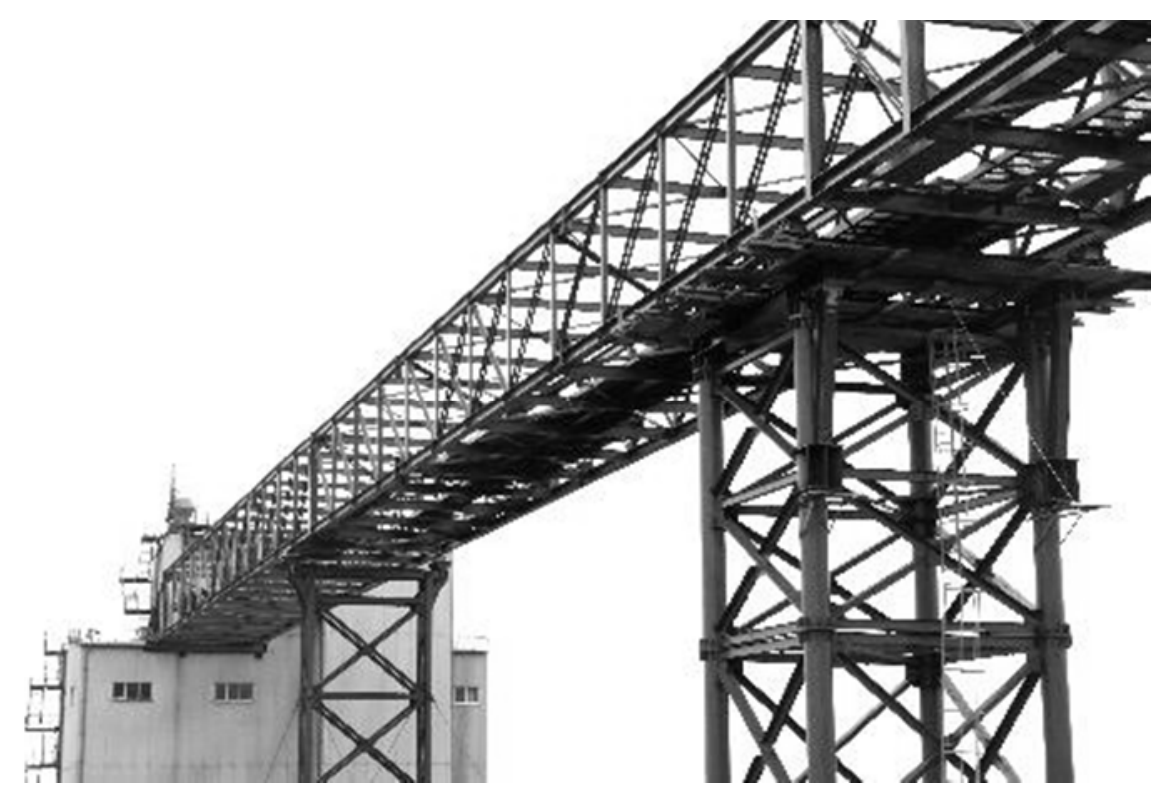

Рис. 6. Галерея в проектном положении

Контроль прогибов велся по контрольным точкам. Максимальный прогиб галереи величиной 300 мм был зафиксирован при максимальном вылете консоли 46,7 м, что незначительно превысило значение, полученное при испытании.

По данным геодезических наблюдений максимальное фактическое отклонение опоры Б от вертикали не превысило 170 мм, что на 30 мм меньше расчетного.

Надвижка галереи с учетом технологических перерывов и работы в одну смену была успешно осуществлена за 9 дней (рис. 5-6).

\section{Выводы}

1. Проведен монтаж конвейерной галереи методом надвижки над эксплуатируемой железной дорогой.

2. Конечно-элементные расчеты, выполненные в программном комплексе «ЛИРАСАПР» дали возможность полноценно проанализировать поведение опор и элементов конвейерной галереи на стадии монтажа, а также учесть возможные динамические воздействия при надвижке.

3. Проведенные натурного испытания конвейерной галереи на монтажные нагрузки, до установки ее в проектное положение, позволили уточнить полученные результаты расчетов и откорректировать конструкцию аванбека.

4. Монтаж всех пролетов конвейерной галереи был успешно осуществлен за 9 дней с отсутствием нештатных ситуаций.

\section{Литература}

1. ДБН В.1.2-2:2006. Навантаження і впливи. [Чинний від 2007-01-01]. - К. Мінрегіонбуд України, 2006. - 78c.(Національний стандарт України).

2. Серия 3.016-1. Неотапливаемые транспортерные галереи пролетами 18, 24, 30 м с ограждающими конструкциями из волнистых асбестоцементных листов. Выпуск 2. Стальные конструкции. Чертежи КМ. Госстрой СССР, 1973. -49с.

3. ДБН В.1.2-14-2009. Загальні принципи забезпечення надійності та конструктивної безпеки будівель, споруд, будівельних конструкцій та основ. [Чинний від 2009-12-01]. - К. Мінрегіонбуд України, 2009. - 41с.(Національний стандарт України).

4. ДБН В.2.6-198:2014. Сталеві конструкції. Норми проектування. [На заміну ДБН В.2.6-163:2010 у частині розділу 1 та ДСТУ Б В.2.6-194:2013, чинні з 2015.01.01]. - Київ: Мінрегіон України 2014. - 199 с. (Національний стандарт України). 
5. ДСТУ Б В.2.6-7-95 (ГОСТ 8829-94). Конструкції будинків і споруд. Вироби будівельні бетонні і залізобетонні збірні. Методи випробувань навантажуванням. Правила оцінки міцності, жорсткості та трищіностійкості. [Чинний від 1996-01-01]. - К. Державний комітет України у справах містобудування і архітектури, 1997. - 45с.(Національний стандарт України).

\section{References}

[1] DBN V.1.2-2:2006. Navantazhennia i vplyvy. [Chynnyi vid 2007-01-01]. - K. Minrehionbud Ukrainy, 2006. - 78s.(Natsionalnyi standart Ukrainy).

[2] Seryia 3.016-1. Neotaplyvaemie transporternie halerey proletamy 18, 24, $30 \mathrm{~m} \mathrm{~s}$ ohrazhdaiushchymy konstruktsyiamy iz volnystikh asbestotsementnыkh lystov. Vipusk 2. Stalnie konstruktsyy. Chertezhy KM. Gosstroi USSR, 1973. -49s.

[3] DBN V.1.2-14-2009. Zahalni pryntsypy zabezpechennia nadiinosti ta konstruktyvnoi bezpeky budivel, sporud, budivelnykh konstruktsii ta osnov. [Chynnyi vid 2009-12-01]. - K. Minrehionbud Ukrainy, 2009. - 41s.(Natsionalnyi standart Ukrainy).

[4] DBN V.2.6-198:2014. Stalevi konstruktsii. Normy proektuvannia. [Na zaminu DBN V.2.6163:2010 u chastyni rozdilu 1 ta DSTU B V.2.6-194:2013, chynni z 2015.01.01]. - Kyiv: Minrehion Ukrainy 2014. - 199 s. (Natsionalnyi standart Ukrainy).

[5] DSTU B V.2.6-7-95 (HOST 8829-94). Konstruktsii budynkiv i sporud. Vyroby budivelni betonni i zalizobetonni zbirni. Metody vyprobuvan navantazhuvanniam. Pravyla otsinky mitsnosti, zhorstkosti ta tryshchinostiikosti. [Chynnyi vid 1996-01-01]. - K. Derzhavnyi komitet Ukrainy u spravakh mistobuduvannia i arkhitektury, 1997. -45 s.(Natsionalnyi standart Ukrainy).

\section{ДОСВІД МОНТАЖУ МЕТАЛЕВОЇ КОНВЕСРНОЇ ГАЛЕРЕЇ МЕТОДОМ НАСУВАННЯ}

Шеховцов І.В., к.т.н., доцент, ORCID 0000-0003-3664-0723

Петраш С.В., к.т.н., доцент, ORCID 0000-0002-8567-3962

Бондаренко О.В., к.т.н., доцент, Шеховцов B.І., к.т.н., доцент Одеська державна академія будівництва та архітектури v.shekhovtsov@ogasa.org.ua, ORCID: 0000-0001-9499-0188

Анотація. Стаття описує досвід установки металевої 146 метрової конвеєрної галереї. Згідно проекту галерея повинна бути влаштована над залізничними коліями, не зупиняючи при цьому на тривалий час експлуатацію залізничного транспорту. Проаналізувавши усі можливі варіанти монтажу та ураховуючи можливості підрядної організації був обраний нетривіальний метод проведення робіт по влаштуванню конвейєрної галереї. Для цього застосовувався метод монтажу, при якому галерея поступово насувається на влаштовані опори. При насуванні вона змінює свою розрахункову схему i, як наслідок, зусилля в конструктивних елементах. Додаткових труднощів додавало те, що монтаж проводився на висоті понад 30 м над рівнем залізничного полотна, що накладало багато обмежень при виконанні монтажних робіт. Для зменшення зусиль в елементах галереї при насуванні до іiі краю був змонтований аванбек, довжиною 10 м. Так як при насуванні розрахункова схема галереї змінювалася кілька разів, то виконувався детальний чисельний аналіз поведінки опор і кожного 3 елементів галереї при проведенні монтажних робіт у скінченоелементному програмному комплексі «ЛІРА-САПР». У розрахунках враховувалися додаткові монтажні навантаження та вітрове навантаження, значення якого було прийнято за даними, що були 
отримані від метеорологічної моніторингової служби. Швидкість вітру приймалась до 10 м/с. Також за допомогою методик, які закладені в програмному комплексі виконувалося оцінювання динамічних характеристик конструкцій галереї. Перед проведенням монтажних робіт були проведені натурні випробування конструкцій галереї, де вимірювалися прогини при максимальній довжині консолі при насуванні. При випробуваннях моделювалось насування галереї та були перевірені різноманітні монтажні випадки. Чисельні розрахунки та натурні випробування підтвердили можливість проведення монтажних робіт з влаштування металевої конвейерної галереї обраним методом, що й було успішно зроблено за 9 днів.

Ключові слова: конвеєрна галерея, монтаж методом насування, аванбек, відправна марка, прогінна будова, опора.

\title{
EXPERIENCE FOR SLIDING METHOD OF STEEL CONVEYOR'S GALLERY PLACEMENT
}

\author{
Shekhovtsov I.V., PhD., Assistant Professor, \\ ORCID 0000-0003-3664-0723 \\ Petrash S.V., PhD., Assistant Professor, \\ ORCID 0000-0002-8567-3962 \\ Bondarenko A.V., PhD., Assistant Professor, \\ Shekhovtsov V.I., PhD., Assistant Professor \\ Odessa State Academy of Civil Engineering and Architecture \\ v.shekhovtsov@ogasa.org.ua, ORCID:0000-0001-9499-0188
}

\begin{abstract}
.
The article describes the experience of installing a metal 146 meter conveyor gallery. According to the project, the gallery should be arranged above the railway tracks, without interrupting the operation of railway transport for a long time. After analyzing all possible installation variants and considering the possibilities of the contractor, a non-trivial method of carrying out works on the arrangement of the conveyor gallery was chosen. For this purpose, the sliding method was used, which suppose the gallery gradually moved to the arranged supports. As it moves, it changes its design scheme and, as a consequence, efforts in the structural elements. Additional difficulties were added by the fact that the installation was carried out at height of more than $30 \mathrm{~m}$ above the level of the railway track, which imposed many restrictions when performing the installation work. To reduce the effort in the elements of the gallery when moving, there was mounted a backbone, $10 \mathrm{~m}$ long to its edge. In a case that the design scheme of the gallery has been changing several times, a detailed numerical analysis of the behavior of the supports and every elements of the gallery during the installation work by the finite elements software program "LIRASAPR" was performed. The calculations took into account additional installation loads and wind loads, the which value was taken from the data from the meteorological monitoring service. Wind speed was up to $10 \mathrm{~m} / \mathrm{s}$. Also, using the techniques which was performed in the software, the dynamic characteristics of the gallery were evaluated. Before the installation works there were carried out full-scale tests of the gallery's structures, where the deflections were measured at the maximum length of the console when pushed. During the tests, the drawing of the gallery was simulated and various mounting cases were checked. Numerical calculations and full-scale tests confirmed the possibility of installation work on the arrangement of the metal conveyor gallery by the chosen method, which was successfully done in 9 days.
\end{abstract}

Keywords: conveyor gallery, assemblage, sliding method placement, launching nose, deliverable assemblies, superstructure, bearings 
УДК 624.012.4

\title{
ПІДБІР РАЦІОНАЛЬНОГО КРОКУ БАЛОК НАСТИЛУ ДЛЯ БАЛОЧНОЇ КЛІТКИ СПРОЩЕНОГО ТИПУ
}

\author{
Янін О.С., - к.т.н., доцент, \\ Херсонський Державний Аграрний Університет, м. Херсон \\ yanin_a@ukr.net, ORCID ID 0000-0003-0230-8669 \\ Новікова С.М., - старший викладач, \\ Херсонський Державний Аграрний Університет, м. Херсон \\ novikova_svetla@ukr.net, ORCID ID 0000-0003-0012-521X
}

Анотація. У статті наведені результати оптимізації кроку балок у балочній клітці спрощеного типу, коли на вертикальні несучі конструкції (стіни, колони) спираються сталеві балки двотаврового профілю. Оптимальний крок балок підібраний таким чином, щоб сумарні витрати сталі на балки і настил були мінімальними. Проведено дослідження, для яких значень кроку, жорсткість балки забезпечена при рівності лівої та правої частин умови міцності за нормальними напруженнями. 3'ясовано, у якому випадку при знайденому оптимальному кроку балок, забезпечена іiі жорсткість. 3 метою з'ясування практичної застосовності отриманих результатів, задача була розв'язана при контрольних числових даних.

Ключові слова: балочна клітка, сталевий настил, крок балок, оптимізація, міцність, жорсткість.

Вступ. В сучасних умовах економія сталі має важливе значення. Тому будівельні конструкції необхідно проектувати таким чином, щоб при заданому діючому навантаженні витрати сталі були зведені до мінімуму.

Аналіз останніх джерел досліджень i публікацій. Питання раціонального проектування сталевих елементів, що працюють на згин розглядаються у ряді праць провідних вітчизняних та закордонних вчених [1-4]. Зокрема, при вільному плануванні сталевої балочної клітки, вирішується задача підбору кроку і прольоту балок виходячи 3 максимального використання їх несучого ресурсу при найбільш раціональній формі поперечного перерізу [5-7]. Якщо, відносно довгі сталеві балки розташовуються досить близько одна від іншої, то виникає протиріччя між жорсткістю балок і необхідністю забезпечення їх міцності за нормальними напруженнями при мінімальному запасі [5-7]. Тобто конструкція стає неефективною з точки зору витрат сталі.

Виділення не розв'язаних раніше частин загальної проблеми. Актуальним є дослідження можливості підбору схеми розміщення балок у плані, яка б відповідала критерію економічності. У якості такого критерію можна розглядати витрати стали на балочну конструкцію у цілому.

Постановка завдання. Розглянемо балочну клітку спрощеного типу, коли на вертикальні несучі конструкції (стіни, колони) спираються сталеві балки двотаврового профілю. На них укладається сталевий настил (рис.1).

Крок балок $\mathbf{X}$ спробуємо підібрати так, щоб сумарні витрати сталі на балки і настил були мінімальними. Такий крок $\mathbf{X}=\mathbf{X}_{\mathbf{0}}$ будемо називати оптимальним. Для його знаходження складемо цільову функцію вартості сталі для настилу і балок на $1 \mathrm{~m}^{2}$ перекриття, перемінним аргументом якої $є$ крок балок $\mathbf{X}$. Потім дослідимо цю функцію на екстремум [6]. Якщо екстремум буде відповідати мінімуму функції i позитивному значенню аргументу, то оптимальний крок балок $\mathbf{X}_{\mathbf{0}}$ може бути знайдений. 

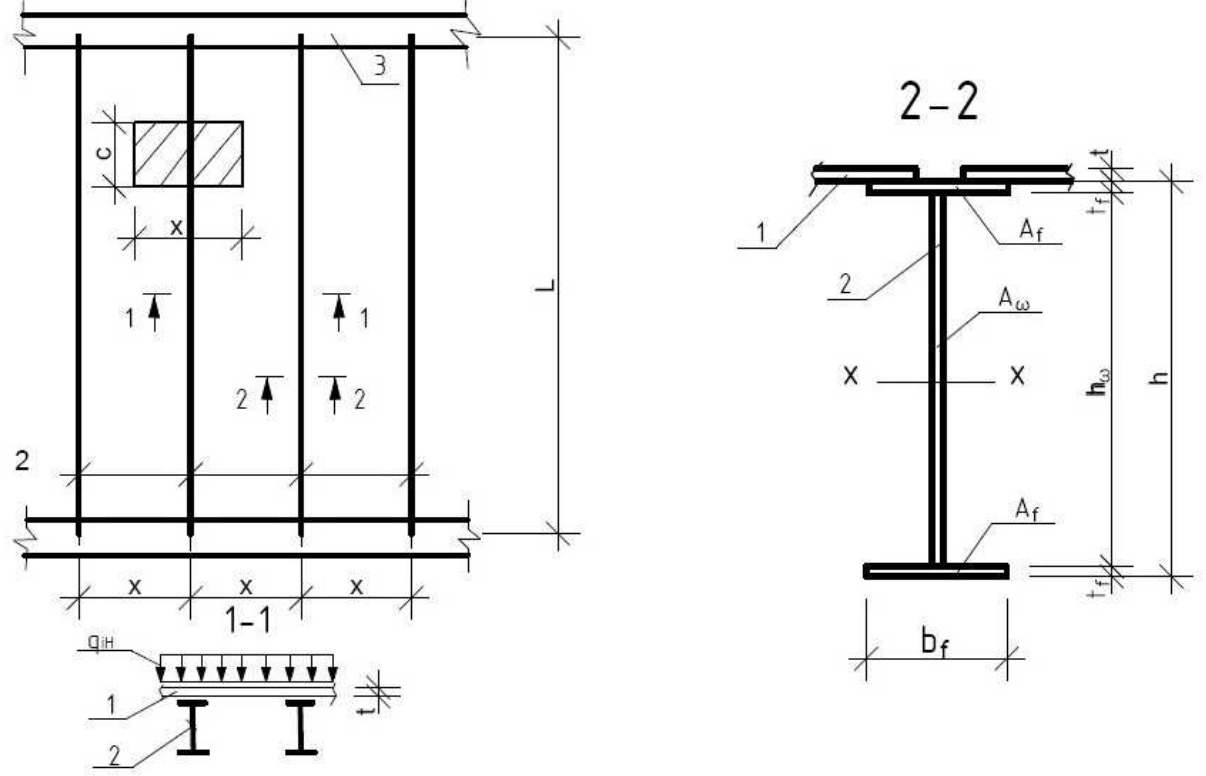

1 - сталевий настил

2 - сталеві балки двотаврового профілю

3 - вертикальні несучі конструкції (стіни, колони)

Рис. 1. Балочна клітка спрощеного типу

Основний матеріал і результати. Виділимо за довжиною балки деяку ділянку шириною C (див.рис.1). Вартість сталі для настилу і балок на ділянці перекриття, площа якої дорівнює $\mathbf{C} \cdot \mathbf{X}$

$$
\mathrm{St}=\ddot{\mathrm{O}}_{i} \cdot \mathrm{t} \cdot \mathrm{c} \cdot \mathrm{x} \cdot \rho_{\text {ñò }}+\ddot{\mathrm{O}}_{\dot{a}} \cdot \grave{\mathrm{A}}_{a} \cdot \tilde{\mathrm{n}} \cdot \rho_{\text {ñò }},
$$

де $\bigsqcup_{н}$ і Цб, грн/кг - ціна 1кг сталі відповідно для настилу і балок;

$\boldsymbol{\rho}_{\mathbf{c},}, \mathrm{K} \Gamma / \mathbf{M}^{3}-$ щільність сталі;

$\mathbf{t}$ - товщина настилу;

$\mathbf{A}_{\sigma}$ - площа поперечного перерізу двотаврової балки (рис.1);

$$
\mathrm{A}_{\sigma}=2 \mathrm{~A}_{\mathrm{f}}+\mathrm{A}_{\omega} \approx 2 \mathrm{~b}_{\mathrm{f}} \mathrm{t}_{\mathrm{f}}+\mathrm{ht}_{\omega}
$$

де $\mathbf{A}_{\mathbf{f}}-$ площа поперечного перерізу однієї полиці;

$\mathbf{A}_{\boldsymbol{\omega}}$ - площа поперечного перерізу стінки.

Вартість сталі для настилу і балок на $1 \mathrm{~m}^{2}$ перекриття

$$
S=\frac{S t}{c \cdot x}=\rho_{c T}\left(Ц_{H} t+Ц_{\sigma} \frac{A_{\sigma}}{x}\right) .
$$

Величини $\mathbf{t}$ і $\mathbf{A}_{\boldsymbol{\sigma}}$ залежать від $\mathbf{X}$. Виразимо їх через $\mathbf{X}$ і підставимо у формулу (3).

Граничне відношення $\mathbf{X} / \mathbf{t}$ виходячи з рівності прогину настилу посередині прольоту гранично припустимому прогину виражається формулою [5]

$$
\frac{\mathrm{x}}{\mathrm{t}}=\frac{4 \mathrm{n}_{\mathrm{оH}}}{15}\left(1+\frac{72 \mathrm{E}_{1}}{\mathrm{n}_{\text {он }}{ }^{4} \mathrm{q}_{1 \mathrm{H}}}\right),
$$


де $\mathbf{n}_{\text {он }}-$ величина, зворотна гранично припустимому прогину;

$\mathbf{q}_{1 н}, \kappa \mathrm{H} / \mathrm{M}^{2}$ - експлуатаційне (нормативне) корисне навантаження на перекриття;

$\mathbf{E}_{\mathbf{1}}$ - модуль пружності сталі при неможливості поперечних деформацій настилу. вигляді

Права частина формули (4) не залежить від $\mathbf{X}$. Тоді функцію $\mathbf{t}_{(\mathbf{x})}$ можна записати у

$$
\mathrm{t}_{(\mathrm{x})}=\mathrm{x} \cdot \frac{1}{\frac{4 \mathrm{n}_{\text {он }}}{15}\left(1+\frac{72 \mathrm{E}_{1}}{\mathrm{n}_{\text {он }}^{4} \mathrm{q}_{\text {1н }}}\right)}=\mathrm{x} \cdot \mathrm{p}_{1} \text {, }
$$

де

$$
\mathrm{p}_{1}=\frac{1}{\frac{4 \mathrm{n}_{\mathrm{он}}}{15}\left(1+\frac{72 \mathrm{E}_{1}}{\mathrm{n}_{\text {он }}^{4} \mathrm{q}_{1 \mathrm{H}}}\right)}=\text { const } \text {. }
$$

Приймемо, що дві однакові полиці і стінка двотаврової балки мають вигляд прямокутників. При цьому висота балки $\mathbf{h} \epsilon$ оптимальною і обчислюється за формулою [7]

$$
\mathrm{h}=\sqrt[3]{\frac{3}{2} \lambda_{\omega} \mathrm{W}}
$$

де $\boldsymbol{\lambda}_{\boldsymbol{\omega}} \approx \mathbf{h} / \mathbf{t}_{\boldsymbol{\omega}}-$ задана гнучкість стінки $\left(\boldsymbol{\lambda}_{\boldsymbol{\omega}}=\mathrm{const}\right)$;

$\mathbf{W}=\mathbf{M} / \mathbf{R} \mathbf{y} \boldsymbol{\gamma}_{\mathbf{c}}-$ потрібний момент опору поперечного перерізу із умови міцності балки за нормальними напруженнями [8];

$\mathbf{R} \mathbf{y}$ - розрахунковий опір сталі, встановлений за межею текучості;

$\gamma_{\mathbf{c}}-$ коефіцієнт умов роботи.

Згинаючий момент $\mathbf{M}$ посередині прольоту балки залежить від невідомого кроку $\mathbf{X}$ i виражається формулою

$$
\mathrm{M}=\frac{\mathrm{q}_{\mathrm{lH}_{\mathrm{H}}} \mathrm{x} \gamma_{\mathrm{f}} 1^{2}}{8} .
$$

де $\gamma_{\mathbf{f}}$ - коефіцієнт надійності за навантаженням;

$\mathbf{l}$ - проліт балки.

Тоді $\mathbf{W}$ є функцією від $\mathbf{X :}$

$$
\mathrm{W}_{(\mathrm{x})}=\frac{\mathrm{q}_{1_{\mathrm{H}}} \mathrm{x} \gamma_{\mathrm{f}} \mathrm{I}^{2}}{8 \mathrm{R}_{\mathrm{y}} \gamma_{\mathrm{c}}}=\mathrm{x} \cdot \mathrm{p}_{2},
$$

де

$$
\mathrm{p}_{2}=\frac{\mathrm{q}_{1 \mathrm{H}} \gamma_{\mathrm{f}} \mathrm{l}^{2}}{8 \mathrm{R}_{\mathrm{y}} \gamma_{\mathrm{c}}}=\mathrm{const}
$$

Величину $\mathbf{W}$ виразимо через розміри поперечного перерізу 


$$
\mathrm{W}=\frac{\mathrm{I}}{0.5 \mathrm{~h}}=\frac{1}{0.5 \mathrm{~h}}\left[\frac{\mathrm{t}_{\omega} \mathrm{h}^{3}}{12}+2 \mathrm{~A}_{\mathrm{f}}(0.5 \mathrm{~h})\right]=\frac{\mathrm{h}^{3}}{6 \lambda_{\omega}}+\mathrm{A}_{\mathrm{f}} \mathrm{h},
$$

де I - момент інерції поперечного перерізу.

3 формули (11) виражаємо площу поперечного перерізу однієї полиці $\mathbf{A}_{\mathbf{f}}$ через $\mathbf{W}$ i представляємо у вигляді функції від $\mathbf{X}$ з урахуванням формул (7) і (9)

$$
\mathrm{A}_{\mathrm{f}}(\mathrm{x})=\frac{1}{\mathrm{~h}}\left(\mathrm{~W}-\frac{\mathrm{h}^{3}}{6 \lambda_{\omega}}\right)=\frac{3}{4} \sqrt[3]{\frac{2 \mathrm{x}^{2} \mathrm{p}_{2}^{2}}{3 \lambda_{\omega}}}
$$

Площу поперечного перерізу стінки $\mathbf{A}_{\boldsymbol{\omega}}$ також представляємо у вигляді функції від $\mathbf{X} 3$ урахуванням формул (7) і (9)

$$
\mathrm{A}_{\omega}(\mathrm{x})=\mathrm{ht}_{\omega}=\frac{\mathrm{h}^{2}}{\lambda_{\omega}}=\frac{3}{2} \sqrt[3]{\frac{2 \mathrm{x}^{2} \mathrm{p}_{2}^{2}}{3 \lambda_{\omega}}}=2 \mathrm{~A}_{\mathrm{f}}(\mathrm{x}) .
$$

Функція площі поперечного перерізу балки прийме вигляд

$$
A_{\sigma}(x)=2 A_{f}(x)+A_{\omega}(x)=3 \sqrt[3]{\frac{2 x^{2} p_{2}^{2}}{3 \lambda_{\omega}}}=x^{2 / 3} p_{3},
$$

де

$$
\mathrm{p}_{3}=3 \sqrt[3]{\frac{2 \mathrm{p}_{2}^{2}}{3 \lambda_{\omega}}}=\mathrm{const}
$$

3 формули (3) з урахуванням формул (5) і (14) отримаємо цільову функцію вартості сталі для настилу і балок на $1 \mathrm{~m}^{2}$ перекриття

$$
\mathrm{S}_{(\mathrm{x})}=\rho_{\mathrm{cT}}\left(\bigsqcup_{\mathrm{H}} \mathrm{t}_{(\mathrm{x})}+Ц_{\sigma} \frac{\mathrm{A}_{\sigma}(x)}{\mathrm{x}}\right)=\rho_{\text {ст }}\left(Ц_{\mathrm{H}} \mathrm{p}_{1} \mathrm{x}+Ц_{\sigma} \mathrm{p}_{3} \mathrm{x}^{-\frac{1}{3}}\right) .
$$

Перша похідна цільової функції

$$
\frac{d \mathrm{~S}_{(\mathrm{x})}}{d \mathrm{x}}=\rho_{\tilde{\mathrm{n} o ̀}}\left(\ddot{\mathrm{O}}_{\mathrm{i}} \mathrm{p}_{1}-\frac{1}{3} \ddot{\mathrm{O}}_{\mathrm{a}} \mathrm{p}_{3} \mathrm{x}^{-\frac{4}{3}}\right)
$$

Дорівнюючи iї нулю знайдемо значення $\mathbf{X}=\mathbf{X}_{\mathbf{0}}$, при якому цільова функція має екстремум

$$
\mathrm{x}_{\mathrm{o}}=\left(\frac{1}{3} \frac{Ц_{\sigma} \mathrm{p}_{3}}{Ц_{\mathrm{H}} \mathrm{p}_{1}}\right)^{\frac{3}{4}}
$$


Легко переконатись, що цей екстремум відповідає мінімуму функції.

Після підстановки у формулу (17) виразів для постійних параметрів $\mathbf{p}_{1}$ i $\mathbf{p}_{3}$ отримаємо

$$
\mathrm{x}_{\mathrm{o}}=\sqrt[4]{\left(\frac{2}{3}\right)^{3}\left(\frac{\coprod_{\sigma}}{Ц_{\text {н }}}\right)^{3} \frac{1}{\lambda_{\omega}}\left(\frac{3 \mathrm{q}_{\text {нн }_{\mathrm{H}}} \gamma_{\mathrm{f}}}{16 \mathrm{R}_{\mathrm{y}} \gamma_{\mathrm{c}}}\right)^{2}\left[\frac{4 \mathrm{n}_{\text {он }}}{15}\left(1+\frac{72 \mathrm{E}_{1}}{\mathrm{n}_{\text {он }}{ }^{4} \mathrm{q}_{1_{\text {н }}}}\right)\right]^{3}} 1 .
$$

При виводі формули для $\mathbf{X}_{\mathbf{0}}$ передбачалося, що поперечний переріз балки підбирався виходячи із забезпечення міцності за нормальними напруженнями. При цьому жорсткість балки при оптимальному кроку $\mathbf{X}_{\mathbf{0}}$ може бути не забезпечена.

3'ясуємо, для яких значень кроку $\mathbf{X}$ жорсткість балки забезпечена при рівності лівої та правої частин умови міцності за нормальними напруженнями. Для цього розв'яжемо таку систему:

$$
\begin{gathered}
\frac{\mathrm{q}_{1 \mathrm{i}} \mathrm{x} \gamma_{\mathrm{f}} 1^{2}}{8 \mathrm{~W}}=\mathrm{R}_{\mathrm{y}} \gamma_{\mathrm{c}} \\
\frac{5}{384} \frac{\mathrm{q}_{11} \mathrm{xl}^{3}}{\mathrm{EI}} \leq \frac{1}{\mathrm{n}_{\mathrm{o}}} \\
\mathrm{I}=\mathrm{W} \cdot 0,5 \mathrm{~h} \\
\mathrm{~h}=\sqrt[3]{\frac{3}{2} \lambda_{\omega} \mathrm{W}}
\end{gathered}
$$

де 1/n $\mathbf{0}$ граничний відносний прогин балки.

Нерівність (20) виражає собою умову жорсткості балки, а рівняння (19) випливає із умови міцності.

Виключивши з системи $\mathbf{I} ; \mathbf{W}$; і $\mathbf{h}$, отримаємо таку умову

$$
\mathrm{x} \geq\left(\frac{5}{24} \frac{\mathrm{R}_{\mathrm{y}} \gamma_{\mathrm{c}} \mathrm{n}_{\mathrm{o}}}{\mathrm{E} \gamma_{\mathrm{f}}}\right)^{3} \frac{16 \mathrm{R}_{\mathrm{y}} \gamma_{\mathrm{c}}}{3 \mathrm{q}_{1 \mathrm{H}} \gamma_{\mathrm{f}} \lambda_{\omega}} 1=\mathrm{x}_{\text {жорстк }}
$$

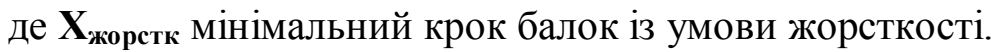

Із виразу (23) випливає, що для забезпечення жорсткості балок, їх крок повинен бути не менше величини $\mathbf{X}_{\text {жорстк. }}$

3’ясуємо, у якому випадку при знайденому $\mathbf{X}_{\mathbf{0}}$ забезпечена жорсткість балок. Для цього треба підставити $\mathbf{X}=\mathbf{X}_{\mathbf{0}}$ із формули (18) в умову (23). Після перетворень отримаємо:

$$
\lambda_{\omega} \geq\left(\frac{5}{24} \frac{\mathrm{R}_{\mathrm{y}} \gamma_{\mathrm{c}} \mathrm{n}_{\mathrm{o}}}{\mathrm{E} \gamma_{\mathrm{f}}}\right)^{4}\left(\frac{16 \mathrm{R}_{\mathrm{y}} \gamma_{\mathrm{c}}}{3 \mathrm{q}_{1 \mathrm{H}} \gamma_{\mathrm{f}}}\right)^{2} \frac{3}{2} \frac{Ц_{\mathrm{H}}}{Ц_{\sigma}} \frac{1}{\frac{4 \mathrm{n}_{\text {он }}}{15}\left(1+\frac{72 \mathrm{E}_{1}}{\mathrm{n}_{\text {он }}^{4} \mathrm{q}_{1 \mathrm{H}}}\right)}=\lambda_{\omega, \text { const }}
$$

Права частина цієї умови $\left(\boldsymbol{\lambda}_{\boldsymbol{\omega}, \mathbf{m i n}}\right)$ пропорційна $\mathbf{R}_{\mathbf{y}}$ у шостому ступені, тобто дуже швидко зростає при збільшенні $\mathbf{R} \mathbf{y}$. Тому, щоб забезпечити жорсткість балок при $\mathbf{X}=\mathbf{X}_{\mathbf{0}}, \mathbf{R y}_{\mathbf{y}}$ повинно бути достатньо малим.

3 метою з'ясування практичної застосовності отриманих результатів, задача була розв'язана при таких даних: 


$$
\mathbf{R}_{\mathbf{y}}=18 \kappa \mathrm{K} / \mathrm{cm}^{2} ; \mathbf{q}_{1 \mathbf{H}}=20 \kappa П а ; 1=12 \mathrm{M} ; \boldsymbol{\lambda}_{\boldsymbol{\omega}}=50 ; \mathbf{n}_{\mathbf{0 H}}=150 ; \mathbf{n}_{\mathbf{0}}=250 ; \boldsymbol{\gamma}_{\mathrm{f}}=1,2
$$

Після виконання розрахунків за наведеними вище формулами були отримані такі результати:

$$
\mathbf{X}_{\mathbf{o}}=54,37 \mathrm{~cm} ; \mathrm{t}=0,521 \mathrm{~cm} ; \mathrm{h}=46,1 \mathrm{~cm} ; \mathbf{X}_{\text {жорстк }}=52,36 \mathrm{~cm} ; \lambda_{\omega, \min }=47,56<\lambda_{\omega}=50 .
$$

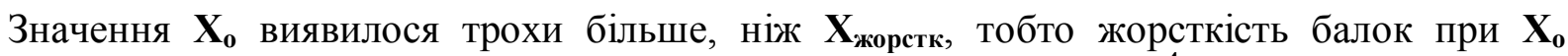

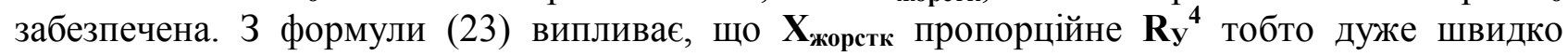
зростає при збільшенні цього параметру. 3 іншого боку, аналізуючи формулу (18) можна зробити висновок, що при збільшенні $\mathbf{R} \mathbf{y}, \mathbf{X}_{\mathbf{0}}$ - зменшується. Тому, при $\mathbf{R} \mathbf{y}>18 \mathrm{\kappa H} / \mathrm{cm}^{2}$ $\mathbf{X}_{\mathbf{0}}<\mathbf{X}_{\text {жорстк }}$, тобто жорсткість забезпечена не буде. Це підтверджує раніше зроблений висновок про те, що треба застосовувати сталь низької міцності.

Товщина настилу $\mathrm{t}=0,521 \mathrm{~cm}$ виявилась трохи менше мінімального значення $\mathrm{t}=0,6 \mathrm{~cm}$, яке рекомендується для застосування. Якщо прийняти проліт балок $\boldsymbol{l}<12 \mathrm{M}$, то $\mathbf{X}_{\mathbf{0}}$, а значить і $\mathbf{t}$ вийдуть ще менше, що є недоцільним. Тому практично задача має сенс при відносно великих прольотах балок.

Висновки. У результаті проведених досліджень було встановлено, що:

- існує принципова можливість підібрати крок балок, який відповідає мінімальній вартості перекриття

- задача має практичний сенс при відносно низької міцності сталі і відносно великих прольотах балок.

У подальших дослідженнях доцільно розглянути цільову функцію приведених витрат 3 урахуванням експлуатаційних витрат.

\section{Література}

1. Металеві конструкції: підруч. [для студ. вищ. навч. закл.] / Нілов О.О., Пермяков В.О., Шимановський О.В. та ін.. - К.: Вид-во «Сталь», 2010. - 869 с.

2. Зорин 3.Я. Стальные конструкции. Проектирование на стадии КМД / 3.Я. Зорин, А.А. Новицкий. - Киев: Сталь, 2015 - 268 с.

3. Гоголь М.В. Регулювання зусиль у металевих конструкціях / М.В. Гоголь, М.Р. Більський, С.I. Віхоть, М.М. Гоголь // Вісник національного університету «Львівська політехніка» «Теорія і практика будівництва». - Львів, 2012. - №737. - С.64-70.

4. Максимов Ю.С. Исследование несущей способности стальных двутавровых балок с вертикально гофрированной стенкой / Ю.С. Максимов, Г.М. Остриков, В.В. Долинский // Строительная механика и расчет сооружений. 1983. - №1. - С. 68-70.

5. Металлические конструкции. Общий курс: Учебник для вузов /Е.И. Беленя, В.А. Балдин, Г.С. Ведеников и др.; Под. общ. ред. Е.И. Беленя. 6-е изд., перераб. и доп. - М.: Стройиздат, 1986. - 560 с., ил.

6. Металлические конструкции. Н.С. Стрелецкий, А.Н. Гениев, Е.И. Беленя, В.А. Балдин, Е.Н. Лессиг ; Под. общ. ред. Н.С. Стрелецкого. 3-е изд., перераб. - М.: Стройиздат, 1961. - 776 с., ил.

7. Муханов К.К. Металлические конструкции. Учебник для вузов. Изд. 3-е, испр. и доп. М., Стройиздат, 1978. 572 с.

8. ДБН В.2.6-198:2014. Сталеві конструкції. Норми проектування». - Київ: Міністерство регіонального розвитку та будівництва України, 2014. - 199с. 


\title{
References
}

[1] Nilov O.O., Permyakov V.O., Shymanovskyy O.V, "Metalevi konstruktsiyi: pidruch. [dlya stud. vyshch. navch. zakl.]", Kyev, Stal, 2010.

[2] Z.YA. Zoryn, A.A. Novytskyy, "Stalnye konstruktsyy. Proektyrovanye na stadyy KMD", Kyev, Stal, 2015.

[3] M.V. Hohol, M.R. Bilskyy, S.I. Vikhot, M.M. Hohol, "Rehulyuvannya zusyl u metalevykh konstruktsiyakh", Visnyk natsionalnoho universytetu «Lvivska politekhnika» «Teoriya i praktyka budivnytstva» vol. 737, Lviv, 2012.

[4] YU.S. Maksymov, H.M. Ostrykov, V.V. Dolynskyy "Yssledovanye nesushchey sposobnosty stalnykh dvutavrovykh balok s vertykalno hofryrovannoy stenkoy", Stroytelnaya mekhanyka y raschet sooruzhenyy, pp. 68-70, vol. 1, 1983.

[5] E.Y. Belenya, V.A. Baldyn, H.S. Vedenykov, "Metallycheskye konstruktsyy. Obshchyy kurs: Uchebnyk dlya vuzov", M.: Stroyyzdat, 1986.

[6] N.S. Streletskyy, A.N. Henyev, E.Y. Belenya, V.A. Baldyn, E.N. Lessyh,” Metallycheskye konstruktsyy", M.: Stroyyzdat, 1961.

[7] K.K. Mukhanov, "Metallycheskye konstruktsyy”, M., Stroyyzdat, 1978.

[8] DBN V.2.6-198:2014. Stalevi konstruktsiyi. Normy proektuvannya». - Kyiv: Ministerstvo rehionalnoho rozvytku ta budivnytstva Ukrayiny, 2014.

\section{ПОДБОР РАЦИОНАЛЬНОГО ШАГА БАЛОК НАСТИЛА ДЛЯ БАЛОЧНОЙ КЛЕТКИ УПРОЩЕННОГО ТИПА}

\author{
Янин А.Е., - к.т.н., доцент, \\ Херсонский Государственный Аграрный Университет г. Херсон \\ yanin_a@ukr.net, ORCID ID 0000-0003-0230-8669 \\ Новикова С.Н., - старший преподаватель, \\ Херсонский Государственный Аграрный Университет г. Херсон \\ novikova_svetla@ukr.net, ORCID ID 0000-0003-0012-521X
}

Аннотация. В статье приведены результаты оптимизации шага балок в балочной клетке упрощенного типа, когда на вертикальные несущие конструкции (стены, колонны) опираются стальные балки двутаврового профиля с уложенным на них стальным настилом.

Оптимальный шаг балок подбирается таким образом, чтобы суммарный расход стали на балки и настил был минимальным. Для этого составлена целевая функция стоимости стали для настила и балок на $1 \mathrm{~m}^{2}$ перекрытия, аргументом которой является шаг балок. Эта функция исследовалась на экстремум. Толщина настила была принята соответствующей предельному отношению шага балок к этой толщине из условия жесткости. Принято, что две одинаковые полки и стенка двутавровой балки имеют вид прямоугольников. При этом высота балки является оптимальной и соответствует минимальным затратам стали.

При выводе формулы для оптимального шага балок предполагалось, что поперечное сечение балки подбирается исходя из обеспечения прочности по нормальным напряжениям. В этом случае, жесткость балки при оптимальном шаге может быть не обеспечена. Поэтому, было проведено исследование, для каких значений шага, жесткость балки обеспечена при равенстве левой и правой частей условия прочности по нормальным напряжениям. Оно опиралось на решение системы уравнений прочности и жесткости, которое позволило получить формулу для минимального шага балок из условия жесткости.

Выяснено, в каком случае при найденном оптимальном шаге балок, обеспечена ее жесткость. Для этого надо, чтобы гибкость стенки балки была не меньше определенного значения. Получена формула для этого минимального значения. Ее анализ показал, что такая гибкость пропорциональна расчетному сопротивлению стали в шестой степени, то есть очень быстро растет при увеличении этого сопротивления. Поэтому, чтобы обеспечить 
жесткость балок при их оптимальном шаге, прочность стали должна быть достаточно малой. Оказалось, что существует принципиальная возможность подобрать шаг балок, который соответствует минимальной стоимости перекрытия.

С целью выяснения практической применимости полученных результатов, задача была решена при контрольных числовых данных. Полученные результаты подтвердили вывод о том, что надо применять сталь низкой прочности. Кроме этого, оказалось, что задача имеет смысл при относительно больших пролетах балок.

Ключевые слова: балочная клетка, стальной настил, шаг балок, оптимизация, прочность, жесткость.

\title{
SELECTING THE RATIONAL PITCH OF BEAMS FLOORING FOR THE BEAM CAGE OF A SIMPLIFIED TYPE
}

\author{
Yanin A.E., - PhD, Assistant Professor, \\ Kherson State Agrarian University, Kherson \\ yanin_a@ukr.net, ORCID ID 0000-0003-0230-8669 \\ Novikova S.N., - Senior Lecturer, \\ Kherson State Agrarian University, Kherson \\ novikova_svetla@ukr.net, ORCID ID 0000-0003-0012-521X
}

\begin{abstract}
The article presents the results of optimizing the pitch of beams in a beam cage of a simplified type, when steel beams of an I-beam profile are supported on vertical supporting structures (walls, columns). Steel flooring is laid on them.

The optimal pitch of the beams is selected so that the total consumption of steel on the beams and flooring is minimal. For this purpose, the objective function of the cost of steel for the flooring and beams per $1 \mathrm{~m} 2$ of flooring is compiled, the argument of which is the step of the beams. This function was investigated for extremum. The thickness of the flooring was adopted corresponding to the limiting ratio of the pitch of the beams to this thickness from the stiffness condition. It is accepted that two identical shelves and a wall of an I-beam have the form of rectangles. Moreover, the height of the beam is optimal and corresponds to the minimum cost of steel.

When deriving the formula for the optimal beam pitch, it was assumed that the beam crosssection is selected based on ensuring strength at normal stresses. In this case, the stiffness of the beam at the optimal pitch may not be provided. Therefore, a study was conducted for what values of the pitch, the rigidity of the beam is ensured when the left and right parts of the strength condition are equal to normal stresses. It relied on the solution of the system of equations of strength and stiffness, which made it possible to obtain a formula for the minimum beam pitch from the stiffness condition.

It was found out in which case, when the optimum pitch of the beams was found, its rigidity was ensured. For this, it is necessary that the flexibility of the beam wall should be at least a certain value. A formula is obtained for this minimum value. Her analysis showed that such flexibility is proportional to the design resistance of the steel to the sixth degree, that is, it grows very rapidly with increasing this resistance. Therefore, in order to ensure the rigidity of the beams at their optimal pitch, the strength of the steel should be sufficiently small. It turned out that there is a fundamental possibility to choose the step of the beams, which corresponds to the minimum cost of overlap.

In order to clarify the practical applicability of the results, the problem was solved with control numerical data. The results confirmed the conclusion that low-strength steel should be used. In addition, it turned out that the problem makes sense with relatively large spans of beams.
\end{abstract}

Key words: beam cage, steel flooring, beam pitch, optimization, strength, rigidity. 


\section{MICT}

Безушко Д.І., Арсірій А.М., Коробенко О.В.

Дослідження впливу жорсткості шпунту на напружено-деформований стан причальних тонких стінок

Гибаленко А.Н., Трофимчук Т.С.

Обеспечение долговременного хранения металлоконструкций при использовании вторичной противокоррозионной защиты

Гилодо А.Ю., Арсирий А.Н., Китаев А.А., Гуренко В.И.

Усиленные деревянные двутавры в малоэтажном строительстве

Голоднов О.І., Іванов Б.В.

Вирівнювання стислих сталевих двотаврових елементів після розвантаження різними способами

Дмитриева Н.В., Агафонова И.П.

Факторная оценка энергоэффективного конструктивно-технологического решения из термопрофиля ЛСТК

Коломійчук Г.П.

Стійкість металевих однопоясних сітчастих куполів з початковими недосконалостями

Купченко Ю.В., Сінгаӥвський П.М., Константінов П.В.

Особливості проектування конвеєрної галереї зернового перевантажувального комплексу

Махінько А.В., Махінько Н.О.

Практичні підходи до розрахунку конічних покрівель сталевих силосних ємностей

\section{Пушкар Н.В.}

Вплив періоду замикання на напружено-деформований стан конструкцій сталевих каркасів одноповерхових будівель

Романенко С.Н., Андриевская Я.П.

Усиление существующей несущей конструкции покрытия

Твардовський І.О., Чучмай С.М., Чучмай О.М., Яременко Н.О.

Підсилення конструкцій одеського державного цирку

Шеховцов И.В., Петраш С.В., Бондаренко А.В., Шеховцов В.И.

Опыт монтажа металлической конвейерной галереи методом надвижки

Янін О.С., Новікова С.М.

Підбір раціонального кроку балок настилу для балочної клітки спрощеного типу 


\section{CONTENTS}

Bezushko D.I., Arsirii A.M., Korobenko O.V.

Research of influence of grooving plane rigidity on strength-deformed condition of berths thin walls

Gibalenko O.M., Trofymchuk T.S.

Ensuring long-term storage of metal structures when using secondary anti-corrosion protection

Gilodo A.Y., Arsirii A.M., Kitayev A.A., Gurenko V.I.

Strengthened wooden double-t in a low-height building

Holodnov O.I, Ivanov B.V.

Flattening of compression steel double-t members after unloading by various means

Dmitrieva N.V., Agafonova I.P.

Factoral assessment of energy-effective constructive-technological solution of the thermoprofile from the LSTK

Kolomiychuk G.P.

Stability of metal single belt mesh domes with initial imperfections

Kupchenko Y.V., Singayevsky P.M., Konstantinov P.V.

Special aspects of the grain handling terminal`s conveyor gallery designing

Makhinko A.V., Makhinko N.O.

Practical approaches to calculation of conical roofs of steel silo capacities

Pushkar N.V.

The influence of the lock period on the stress-strain state of the bearing structures of onestorey buildings steel frames

Romanenko S.M., Andrievska Y.P.

Strengthening of the existing bearing structure of the coating

Tvardovsky I.O., Chuchmay S.M., Chuchmai O.M., Yaremenko N.O.

Strengthening design of the odessa holding circus

Shekhovtsov I.V., Petrash S.V., Bondarenko A.V., Shekhovtsov V.I.

Experience for sliding method of steel conveyor's gallery placement

Yanin A.E., Novikova S.N.

Selecting the rational pitch of beams flooring for the beam cage of a simplified type 